Cid Moreira Boechat

\title{
O designer como agente organizacional na produção multidisciplinar de material didático para
}

EAD

Dissertação de Mestrado

Dissertação apresentada como requisito parcial para obtenção do título de Mestre pelo Programa de PósGraduação em Design da PUC-Rio.

Orientadora: Profa. Claudia Renata Mont'Alvão Bastos Rodrigues

Rio de Janeiro

Março de 2018 
Cid Moreira Boechat

\section{O designer como agente organizacional na produção multidisciplinar de material didático para}

Dissertação apresentada ao Programa de Pós-Graduação em Design da PUC-Rio como requisito parcial para obtenção do grau de Mestre em Design. Aprovada pela Comissão Examinadora abaixo assinada.

\section{Profa. Claudia Renata Mont'Alvão Bastos Rodrigues \\ Orientador \\ Departamento de Artes e Design - PUC-Rio}

Prof. Agnaldo da Conceição Esquincalha Universidade do Estado do Rio de Janeiro - UERJ

Profa. Rita Maria de Souza Couto Departamento de Artes e Design - PUC-Rio

Profa. Monah Winograd Coordenadora Setorial do Centro de Teologia e Ciências Humanas - PUC-Rio

Rio de Janeiro, 07 de março de 2018 
Todos os direitos reservados. É proibida a reprodução total ou parcial do trabalho sem autorização da universidade, do autor e do orientador.

\section{Cid Moreira Boechat}

Graduado em Produção Editorial pela Escola de Comunicação da UFRJ em 2002. Especializado em Ergonomia, Usabilidade e Arquitetura da Informação pela PUC-Rio em 2010. Trabalha com Educação a Distância desde 2003, com foco na produção de material didático, objetos de aprendizagem e interfaces em Ambientes Virtuais de Aprendizagem.

Ficha Catalográfica

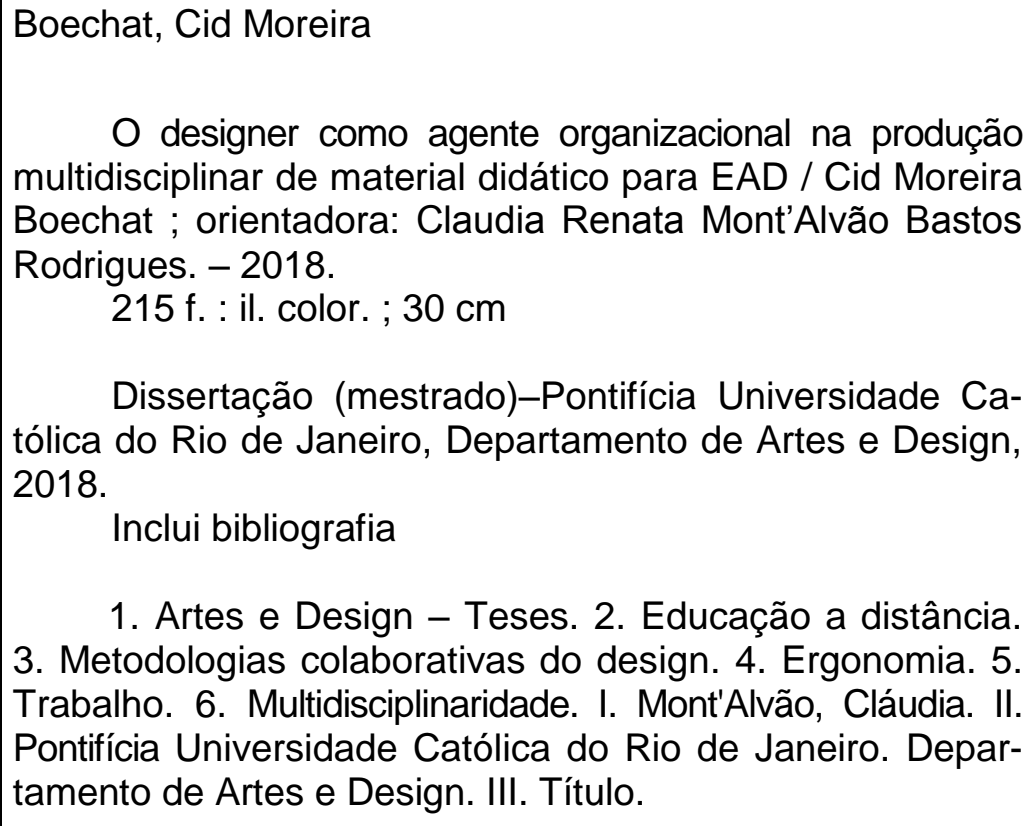

1. Artes e Design - Teses. 2. Educação a distância. 3. Metodologias colaborativas do design. 4. Ergonomia. 5. Trabalho. 6. Multidisciplinaridade. I. Mont'Alvão, Cláudia. II. Pontifícia Universidade Católica do Rio de Janeiro. Departamento de Artes e Design. III. Título. 
Para Daniel, Teresa e Juliana, que me fizeram chegar até aqui.

Para Lara, que me faz seguir a partir daqui. 


\section{Agradecimentos}

Primeiramente, a Deus e aos meus familiares. Pela compreensão com as minhas ausências e falta de tempo.

Um agradecimento especial aos gestores e funcionários da Fundação Cecierj, pelo comprometimento com o trabalho - apesar de todas as dificuldades - e pela compreensão que tornou esta pesquisa possível.

Às minhas colegas de orientação, Carolina Bozzi e Íris Arraes, por todas as dicas, links trocados e livros indicados. Boa sorte nas suas vidas acadêmicas!

Agradecimentos especiais à minha orientadora, Claudia Mont'Alvão, sem a qual esse trabalho não seria possível. Obrigado pelo incentivo e paciência.

A todos do PPG em Design da PUC-Rio, especialmente ao pessoal do LEUI.

Um obrigado muito especial ao colega Gabriel Cruz, pelo incentivo que me fez tentar o mestrado. Obrigado por todas as dicas. Não estaria aqui sem elas.

Obrigado, PUC-Rio, pela estrutura, quadro de professores e incentivo à pesquisa científica. É uma honra ser parte desta instituição. 


\section{Resumo}

Boechat, Cid Moreira; Mont'Alvão, Claudia Renata Bastos Rodrigues. O designer como agente organizacional na produção multidisciplinar de material didático para EAD. Rio de Janeiro, 2018. 215p. Dissertação de Mestrado - Departamento de Artes e Design, Pontifícia Universidade Católica do Rio de Janeiro.

A graduação a distância cresceu no Brasil 2.200\% entre 2003 e 2013. Neste mesmo período, mudanças tecnológicas quebraram paradigmas e exigiram a formação de equipes multidisciplinares para a produção de material didático. Talvez, este quadro ajude a explicar porque os desafios organizacionais são um problema apontado por instituições de ensino que passam a oferecer Educação a Distância (EAD). Esta dissertação se baseia na predição de que o uso de metodologias do Design e da Ergonomia na gestão de ambientes de trabalho na EAD, juntamente com a participação efetiva dos profissionais envolvidos, podem trazer resultados diferenciados na resolução de problemas organizacionais. Ao pesquisar esta questão, este trabalho contextualizou o cenário atual da EAD brasileira e suas dificuldades frente à legislação, aos aspectos culturais e à adequação às novas ferramentas tecnológicas. Na sequência, abordou os diferentes sistemas de trabalho e as questões que envolvem a relação entre as organizações e seus funcionários. Destacou, ainda, as particularidades que devem ser observadas ao se montar equipes multidisciplinares no âmbito da EAD. Em seguida, detalhou as metodologias que enxergam o Design e a Ergonomia como ferramentas de mudança, gestão e criação de cultura de trabalho e a importância da participação e envolvimento dos profissionais na busca por melhorias no seu ambiente produtivo. Por fim, para aferir a aplicabilidade dos conceitos levantados, realizou um estudo de caso na equipe do Departamento de Material Didático da Fundação Cecierj. Através de entrevistas estruturadas e de um questionário online, o estudo chegou a uma série de sugestões de melhoria e mudanças para o objeto abordado, baseadas na participação dos envolvidos e nos conceitos organizacionais do Ergodesign.

\section{Palavras-chave}

Educação a Distância; Metodologias colaborativas do Design; Ergonomia; Trabalho; Multidisciplinaridade; Gestão 


\section{Abstract}

Boechat, Cid Moreira; Mont'Alvão, Claudia Renata Bastos Rodrigues (Advisor). The designer as an organizational agent in the multidisciplinary production of distance education courseware. Rio de Janeiro, 2018. 215p. Dissertação de mestrado - Departamento de Artes, Pontifícia Universidade Católica do Rio de Janeiro.

The brazilian distance graduation grew 2,200\% between 2003 and 2013, exactly when technological changes broke paradigms and required the assembly of multidisciplinary teams for the production of didactic material. Perhaps, this helps to explain why organizational challenges are a problem pointed out by educational institutions that started to offer Distance Education. This dissertation is based on the prediction that the use of Design and Ergonomics methodologies in the management of work environments in ODL, together with the effective participation of the stakeholders, can bring different results in the resolution of organizational problems. For this, this dissertation contextualized the current scenario of the Brazilian ODL and its difficulties regarding legislation, cultural aspects and adaptation to the new technological tools. In the sequence, it discussed the different work systems and the issues that involve the relationship between organizations and their employees. It was also highlighted the particularities that should be observed when setting up multidisciplinary teams within ODL. Next, was detailed the methodologies that see Design and Ergonomics as tools of change, management and work culture creation, besides the importance of the professionals' participation and involvement when searching for improvements in their work environment. Finally, to verify the applicability of the concepts raised, a case study was conducted in the didactic material department of the Cecierj Foundation. Through structured interviews and an online questionnaire, the study reached a series of suggestions for improvement and changes to the object addressed, based on the stakeholders' participation and the organizational concepts of Ergodesign.

\section{Keywords}

Distance Education; Collaborative methodologies of Design; Ergonomics; Work; Multidisciplinarity; Management 


\section{Sumário}

1. Introdução 20

1.1. Delineamento da pesquisa 22

1.1.1. Tema 22

1.1.2. Objeto de estudo 23

1.1.3. Problema 23

1.1.4. Predições 23

1.1.5. Objetivo geral 24

1.1.6. Objetivos específicos 24

1.1.7. Justificativa 25

1.1.8. Metodologia adotada 26

1.2. Estrutura da dissertação: objetivos e resumo de cada capítulo 27

$\begin{array}{ll}\text { 1.2.1.Resumo dos capítulos } & 28\end{array}$

2. Graduação a distância no Brasil: desenvolvimento, contexto

$\begin{array}{ll}\text { e desafios } & 30\end{array}$

2.1. EAD no Século XX: da carta ao e-mail 30

2.2. Século XXI: o salto da modalidade a distância 36

2.3. EAD, TICs e inovações tecnológicas 38

2.4. A tecnologia e as questões pedagógicas na EAD 44

2.5. A multidisciplinaridade na produção de material didático $\begin{array}{ll}\text { para EAD } & 46\end{array}$

2.6. Evasão e obstáculos na EAD 49

3. A relação entre o trabalho, as organizações e as pessoas 53

3.1. O trabalho e os diferentes sistemas de produção 53

3.1.1. O sistema taylorista/fordista 55

3.1.2. O sistema toyotista (flexível) 57 
3.2. As organizações e suas relações com os funcionários

3.2.1. A cultura organizacional

3.2.2. A gestão de pessoas

3.2.3. A estrutura organizacional

3.3. A montagem e o gerenciamento de equipes multidisciplinares em EAD

4. O Design e a Ergonomia aplicados em questões organizacionais

4.1. O Design e a Ergonomia como ferramentas de mudança organizacional 76

4.1.1. O Design aplicado em questões organizacionais 77

4.1.2. A Ergonomia aplicada em questões organizacionais 90

4.2. O Ergodesign Organizacional: uma visão humanista, participativa, sistêmica e contextual

4.3. O Ergodesign Organizacional aplicado na produção de material didático em EAD

5. A produção multidisciplinar de material didático na Fundação Cecierj: um estudo de caso

5.1. A opção pelo estudo de caso

5.2. Delineamento metodológico

5.3. Pesquisa bibliográfica

5.4. Escolha da unidade de análise e do local da pesquisa

5.4.1. Fundação Cecierj: características e cenário

5.4.2. Consórcio Cederj: educação superior a distância pública e gratuita para o Estado do Rio de Janeiro

5.4.3. A crise econômica do Estado do Rio de Janeiro a partir de 2015

5.5. Identificação dos processos, atores envolvidos e do contexto de trabalho 
5.5.2. Levantamento dos processos e fluxogramas de produção do setor

5.6. Entrevistas estruturadas com os profissionais da equipe multidisciplinar

5.6.1. Organização da pauta da entrevista

5.6.2. Metodologia da arguição 126

5.6.3. Seleção da amostra e participação dos funcionários

5.7. Análise de conteúdo das entrevistas estruturadas

5.7.1. Pré-análise 130

5.7.2. Análise de conteúdo: exploração do material e resultados

5.7.2.1. Categoria 1 - Opinião dos profissionais sobre os colegas e sobre a proposta da Fundação

5.7.2.2. Categoria 2 - Condições de trabalho

5.7.2.3. Categoria 3 - Questões processuais do setor de material didático

5.7.2.4. Categoria 4 - Questões gerais da Fundação Cecierj

5.7.2.5. Categoria 5 - Visão sobre as mudanças propostas para o setor

5.7.2.6. Categoria 6 - Sugestões de melhoria dos profissionais

6. Elaboração colaborativa de uma proposta de melhoria para um sistema de trabalho multidisciplinar de EAD

6.1. Contexto encontrado e escolha do método de pesquisa

6.2. Questionário online para validação das propostas e sugestões de melhoria

6.2.1. Redação das perguntas do questionário 148

6.2.2. Aplicação do questionário 150

6.2.3. Resultados do questionário 
7. Conclusões e desdobramentos futuros

7.1. Conclusões e reflexões sobre a pesquisa

7.2. Sugestões de melhoria e mudança para o setor de Material

Didático da Fundação Cecierj

7.3. Desdobramentos futuros

172

Referências bibliográficas

Anexos

Anexo I - Parecer positivo do Comitê de Ética da PUC-Rio para a realização desta pesquisa

Apêndices

185

Apêndice I - Termo de consentimento para entrevista estruturada

Apêndice II - Contagem de ocorrências da análise de conteúdo,

divididas por categorias

Apêndice III - Texto de introdução do questionário online

Apêndice IV - Pauta do questionário online

Apêndice V - Comentários abertos dos respondentes do

questionário online

Apêndice VI - Organograma proposto e validado no questionário

para o Setor de Material Didático do Cecierj

Apêndice VII - Modelo integrado de produção do material didático proposto e validado no questionário 


\section{Lista de figuras}

Figura 2.1- Evolução do Número de Cursos de Graduação, segundo a Modalidade de Ensino, entre 2010 e 2013

Figura 2.2 - Matrículas na graduação a distância, em termos absolutos 37 Figura 2.3 - Ferramentas utilizadas para o compartilhamento de materiais com os alunos

Figura 2.4 - Combinação entre os novos paradigmas e as TICs

Figura 2.5 - Modo de produção dos materiais audiovisuais para EAD em 2014

Figura 2.6 - Distribuição dos cursos regulamentados totalmente a distância oferecidos em 2014, de acordo com os materiais e a Disponibilização

Figura 2.7 - Causas mais citadas para a evasão em cursos regulamentados semipresenciais em 2014

Figura 2.8 - Obstáculos enfrentados pelas instituições formadoras na oferta de cursos EAD em 2014

Figura 3.1 - Linha de montagem fordista 56

Figura 3.2 - Tipologia cultural proposta por Cameron e Quinn, 2006 62

Figura 3.3 - Os modelos centralizado e descentralizado de gestão de pessoas

Figura 3.4 - Modelo de Diagnóstico de RH 66

Figura 3.5 - Metodologia para concepção de cursos online 69

Figura 4.1 - As Quatro Ordens do Design e suas áreas de atuação 78

Figura 4.2 - Níveis de conhecimento e formas de expressá-los

Figura 4.3 - Representação básica do conceito de sistemas de Trabalho

Figura 4.4 - Metodologias do Design e da Ergonomia aplicáveis na gestão de equipes de trabalho

Figura 4.5 - Características básicas da abordagem do Ergodesign no campo organizacional 
Figura 4.6 - Modelo de sistema de trabalho, adaptado para a produção multidisciplinar de material para a EAD

Figura 5.1 - Localização dos polos presenciais de EAD do Consórcio Cederj

Figura 5.2 - Fluxograma do processo linear de produção de material didático do Cederj, adotado até 2015

Figura 5.3 - Fluxograma do processo integrado de produção de material didático do Cederj, adotado a partir de 2015

Figura 6.1 - Sequência de execução de uma pesquisa Delphi

Figura 6.2 - Divisão do número de respondentes do questionário, Por Gênero

Figura 6.3 - Idades declaradas pelos respondentes

Figura 6.4 - Tempo de trabalho na Fundação Cecierj declarados pelos respondentes, agrupados pelas datas dos concursos públicos Realizados

Figura 7.1 - Organograma proposto pela pesquisa para o Setor de Material Didático do Cecierj, validado no questionário online 168 Figura 7.2 - Comparativo entre o modelo de produção adotado pelo Cecierj em 2017 e o proposto e validado pela dissertação 


\section{Lista de tabelas}

Tabela 1.1- Capítulos da dissertação e seus objetivos 27

Tabela 2.1- Categorias de oferecimento de ensino a distância 36

Tabela 2.2 - Algumas mudanças tecnológicas surgidas no período

De forte crescimento da EAD brasileira 41

Tabela 2.3 - Opções para o uso de LMS em cursos via Web 43

Tabela 3.1 - Características dos tipos de cultura propostos por

Cameron e Quinn (2006) 61

Tabela 3.2 - As cinco bases da influência e poder interpessoais $\quad 63$

Tabela 3.3 - Diferenças entre os funcionários vistos como recursos e vistos como parceiros 64

Tabela 3.4 - Tipos de organizações, suas características e estruturas 67

Tabela 3.5 - Características de subequipes envolvidas na produção

de material didático em EAD

70

Tabela 3.6 - As novas necessidades da administração de recursos humanos

Tabela 3.7 - Quatro enfoques para a organização e gestão da elaboração de cursos a distância relacionados à composição das equipes

Tabela 4.1 - As Ordens do Design e os problemas de Design abordados por elas

Tabela 4.2 - Atitudes e ações do designer inserido no campo do Design estratégico e de Gestão

Tabela 4.3 - Atributos do Design Thinking

Tabela 4.4 - Progressão do nível de envolvimento do usuário em um projeto

Tabela 4.5 - Características das metodologias de Design aplicáveis no campo organizacional

Tabela 4.6 - Características gerais da Macroergonomia

Tabela 4.7 - Subsistemas presentes em um sistema sociotécnico de trabalho 
Tabela 4.8 - Dimensões principais de um sistema de trabalho

Tabela 4.9 - Matriz do esquema de classificação de tecnologias de Perrow 97

Tabela 4.10 - Tipos de tecnologia de um sistema sociotécnico 97

Tabela 4.11 - Fatores relevantes a serem considerados em um subsistema de pessoal

Tabela 4.12 - Matriz do esquema de classificação do nível de Incerteza do ambiente externo

Tabela 4.13 - Tipos de estrutura organizacional e os cenários em que funcionam melhor

Tabela 4.14 - Questões que conduzem um projeto centrado no ser humano de construção de um sistema

Tabela 4.15 - Papéis que o ergonomista pode desempenhar em abordagens participativas

Tabela 4.16 - Tipos de abordagem na participação de steakholders em uma organização

Tabela 4.17 - Princípios para adaptação e melhoria macroergonômicas de um sistema

Tabela 4.18 - Características das metodologias ergonômicas aplicáveis no campo organizacional

Tabela 5.1 - Delineamento das etapas do estudo de caso

Tabela 5.2 - Aspectos metodológicos dos cursos oferecidos pelo Consórcio Cederj

Tabela 5.3 - Atribuições dos entes no Consórcio Cederj

Tabela 5.4 - Aspectos importantes a serem considerados em um estudo de campo

Tabela 5.5 - Subequipes de produção de material didático do

Cederj, seu número de profissionais e suas funções básicas

Tabela 5.6 - Perguntas da entrevista estruturada e seus objetivos

Tabela 5.7 - Divisão dos participantes das entrevistas, em relação Ao cargo ocupado

Tabela 5.8 - Lista de respondentes, tipo de entrevista e local de realização 
Tabela 5.9 - Resumo da pré-análise de conteúdo das entrevistas

Tabela 5.10 - Unidades de registro e de contexto da Categoria $1 \mathrm{da}$ análise de conteúdo

Tabela 5.11 - Unidades de registro e de contexto da Categoria 2 da análise de conteúdo

Tabela 5.12 - Unidades de registro e de contexto da Categoria 3 da análise de conteúdo

Tabela 5.13 - Unidades de registro e de contexto da Categoria 4 da análise de conteúdo

Tabela 5.14 - Unidades de registro e de contexto da Categoria 5 da análise de conteúdo

Tabela 5.15 - Unidades de registro e de contexto da Categoria 6 da análise de conteúdo

Tabela 5.16 - Unidades de registro e de contexto da Categoria 7 da análise de conteúdo

Tabela 6.1 - Resultados da pergunta 1 do questionário

Tabela 6.2 - Resultados da pergunta 2 do questionário

Tabela 6.3 - Resultados da pergunta 3 do questionário

Tabela 6.4 - Resultados da pergunta 4 do questionário

Tabela 6.5 - Resultados da pergunta 5 do questionário

Tabela 6.6 - Resultados da pergunta 6 do questionário

Tabela 6.7 - Resultados da pergunta 7 do questionário

Tabela 6.8 - Resultados da pergunta 8 do questionário

Tabela 6.9 - Resultados da pergunta 9 do questionário

Tabela 6.10 - Resultados da pergunta 10 do questionário

Tabela 6.11 - Resultados da pergunta 11 do questionário

Tabela 6.12 - Resultados da pergunta 12 do questionário

Tabela 6.13 - Resultados da pergunta 13 do questionário

Tabela 6.14 - Resultados da pergunta 14 do questionário

Tabela 6.15 - Resultados da pergunta 15 do questionário

Tabela 6.16 - Resultados da pergunta 16 do questionário

Tabela 6.17 - Resultados da pergunta 17 do questionário 
Tabela 6.19 - Resultados da pergunta 19 do questionário

Tabela 6.20 - Resultados da pergunta 20 do questionário 158

Tabela 6.21 - Resultados da pergunta 21 do questionário 159

Tabela 6.22 - Resultados da pergunta 22 do questionário 159

Tabela 6.23 - Resultados da pergunta 23 do questionário 159

Tabela 6.24 - Resultados da pergunta 24 do questionário 160 


\section{Abreviaturas e siglas}

ABED - Associação Brasileira de Educação a Distância

AVA - Ambiente Virtual de Aprendizagem

Cecierj - Fundação Centro de Ciências e Educação Superior a Distância do Estado do Rio de Janeiro

Cederj - Centro de Educação a Distância do Estado do Rio de Janeiro

Cefet/RJ - Centro Federal de Educação Tecnológica Celso Suckow da Fonseca

EAD - Educação a Distância

IES - Instituições de Ensino Superior

LDB - Lei de Diretrizes e Bases da Educação

MEC - Ministério da Educação

MOBRAL - Movimento Brasileiro de Alfabetização

PNE - Plano Nacional de Educação

QVT - Qualidade de Vida no Trabalho

$\mathrm{RH}$ - Recursos Humanos

Seed - Secretaria de Educação a Distância do Ministério da Educação

SENAC - Serviço Nacional de Aprendizagem Comercial

SESu - Secretaria de Educação Superior do Ministério da Educação

TICs - Tecnologias de Informação e Comunicação

UAB - Universidade Aberta do Brasil

UENF - Universidade Estadual do Norte Fluminense Darcy Ribeiro

UERJ - Universidade do Estado do Rio de Janeiro

UFF - Universidade Federal Fluminense

UFRJ - Universidade Federal do Rio de Janeiro

UFRRJ - Universidade Federal Rural do Rio de Janeiro

UNED - Universidad Nacional de Educación a Distancia.

UNIRIO - Universidade Federal do Estado do Rio de Janeiro 
(...) design is fundamentally an affirmation of human dignity. It is an ongoing search for what can be done to support and strengthen the dignity of human beings as they act out their lives in variety social, economic, political, and cultural circumstances.

Richard Buchanan, Human Dignity and Human Rights: Thoughts on the Principles of Human-Centered Design 


\section{Introdução}

O Brasil é um país de dimensões continentais. A possibilidade de vencer distâncias e aumentar o número de vagas fora dos grandes centros urbanos dá à Educação a Distância um papel importante, mas que deve se preocupar com a qualidade e as particularidades que a modalidade demanda. "A EAD precisa de orientações claras quanto às dimensões de qualidade e do reconhecimento das especificidades de seus alunos" (ARRUDA; ARRUDA, 2015, p. 334).

A Educação a Distância pode apresentar, graças as suas características intrínsecas e questões culturais, dificuldades de adoção e implementação por parte de alunos e profissionais. Segundo Moran, Valente e Arantes (2011), muitos se sentem desconfortáveis nos ambientes virtuais, demoram a se adaptar e sentem falta da turma presencial. O ambiente digital, para quem não está acostumado, pode ser confuso e distante. Não fossem estas questões complicadoras por si só, a velocidade do surgimento de novas tecnologias e a necessidade de sua adoção pelas instituições tornou o ensino superior à distância de larga escala um desafio ainda maior e mais complexo. Ao mesmo tempo, observando-se os números oficiais do Ministério da Educação, constata-se que, entre 2003 e 2013, a EAD superior registrou impressionantes $2.200 \%$ de aumento (BRASIL, 2015), passando de menos de 50.000 matrículas para mais de 1,1 milhão.

É importante relacionar que essa explosão da modalidade a distância no Brasil ocorreu num período onde avanços como smartphones, e-books e tablets causaram mudanças de paradigmas sociais e educacionais. Aumentou-se, além dos custos, a necessidade de formação de equipes multidisciplinares. Para confeccionar esse novo material didático, podem ser envolvidos profissionais de formações díspares como conteudistas de várias áreas do conhecimento, desenhistas instrucionais, designers gráficos, ilustradores, web designers, programadores, tutores, revisores, entre outros. 
Não causaria surpresa se todos esses fatores impactassem os processos internos de produção do material didático, trazendo problemas de gestão e organização. Dificuldades que não são exclusividade dos que praticam EAD, mas que na Educação a Distância caracterizam um problema considerável: segundo os Censos EAD.br de 2013 e de 2014 da ABED, os desafios organizacionais das instituições que começam a oferecer a modalidade representam o segundo maior obstáculo reportado, atrás apenas da evasão de alunos.

Esta dissertação se baseia na predição de que o uso de metodologias de Design e Ergonomia, aplicadas em gestão de Educação a Distância, podem trazer resultados diferenciados para a questão organizacional das equipes de material didático. Isso ocorreria, pois essas metodologias projetam sistemas produtivos com uma visão mais centrada no ser humano do que a Gestão tradicional (BUCHANAN, 2015), com participação efetiva dos profissionais envolvidos.

Para aferir a aplicabilidade desses conceitos na prática, este trabalho optou por um estudo de caso na Fundação Cecierj, órgão que faz parte da Secretaria de Ciência e Tecnologia do Estado do Rio de Janeiro e oferece graduação EAD semipresencial. A Fundação possui as características multidisciplinares e particularidades necessárias ao desenvolvimento da pesquisa. $\mathrm{O}$ estudo de caso foi o método escolhido, pois, conforme Yin (2001), tem a "capacidade de lidar com uma ampla variedade de evidências - documentos, artefatos, entrevistas e observações".

Neste cenário, para construir a base da pesquisa, primeiramente será contextualizada a EAD no Brasil até o momento atual. Serão abordadas características gerais, dados levantados, obrigações legais e problemas encontrados. O foco da análise são os cursos de graduação, mais dependentes das equipes multidisciplinares. Além disso, esses cursos possuem obrigações semipresenciais, mais processos internos e maiores exigências da legislação.

Em seguida, serão abordadas questões internas ao ambiente de trabalho. Por exemplo, a evolução dos sistemas produtivos - da linha de montagem repetitiva até as equipes de trabalho colaborativas. Outros tópicos serão analisados: a relação entre as organizações e seus funcionários; a importância das políticas de gestão e de pessoas; e quais características devem ser levadas em conta na montagem de equipes multidisciplinares de EAD. Na sequência, serão elencadas as metodologias do Design que se propõem como ferramentas de mudança, gestão e criação 
de cultura de trabalho. Essas abordagens adotam uma visão como a que Boland Jr. e Collopy (2004) chamam de "atitude do Design" para a resolução de problemas. Nelas, posiciona-se o designer como um facilitador de processos colaborativos. Nesse sentido, este trabalho reforçará a importância de se considerar que a experiência cotidiana e tácita dos envolvidos nos sistemas de trabalho é fundamental para o encontro de soluções e melhorias.

Também serão relacionadas a visão da Ergonomia aplicada na análise, avaliação e projeto dos sistemas sociotécnicos de trabalho, como a chamada Macroergonomia. Segundo Hendrick e Kleiner (2002), a Macroergonomia, enquanto subdisciplina, foca na interface entre homem e organização e nos fatores humanos, tecnológicos e contextuais (internos e externos à organização) que influem na hora de projetar sistemas de trabalho.

Por fim, com toda a base teórica e contextual levantada, será feito o estudo de caso. Em campo, serão levantados dados para a identificação dos processos e atores envolvidos na produção de material didático. Também serão identificados os principais problemas e dificuldades que os profissionais sentem no seu cotidiano. Com base nessas informações, e levando-se em conta o perfil dos atores envolvidos no processo e o contexto onde atuam, se escolherá os melhores métodos, técnicas e ferramentas de Design e/ou Ergonomia para que sejam traçadas, colaborativamente, propostas de melhoria, mudanças processuais e de cultura de trabalho.

\section{1.}

\section{Delineamento da pesquisa}

\subsection{1}

Tema

Uso de metodologias do Design e da Ergonomia como ferramentas organizacionais em ambientes multidisciplinares de EAD, aplicando-as em sistemas de trabalho para a resolução de problemas e melhoria de processos. 


\subsection{2.}

\section{Objeto de estudo}

A aplicação de metodologias de Design e Ergonomia em ambientes multidisciplinares de EAD da Fundação Cecierj.

\subsection{3.}

\section{Problema}

Segundo livros, artigos e pesquisas, a EAD encontra algumas questões problemáticas causadas pela sua natureza. Entre elas: dificuldade de adaptação de professores, alunos e profissionais; e crescimento muito rápido da Educação a Distância brasileira, num momento de grande necessidade de uso de ferramentas tecnológicas. Esta segunda questão tornou a EAD muito dependente de equipes multidisciplinares (desenhistas instrucionais, docentes, designers web, tutores, etc.).

As particularidades da EAD podem causar o estranhamento de atores fundamentais, gargalos de produção, erros processuais e estruturais. Motivos plausíveis para a evasão de alunos e fim de cursos.

Considerando os problemas citados, como utilizar o Design e a Ergonomia para elaborar, colaborativamente, propostas de mudanças na cultura de trabalho e na gestão de pessoas e de processos, em ambientes multidisciplinares de EAD?

\subsection{4.}

\section{Predições}

Ao projetar em equipe, o Design deve atuar na interação entre pessoas tanto quanto na interação entre pessoas e produtos/objetos/interfaces;

Os usuários intermediários (os profissionais que constroem os produtos) têm a mesma importância que o usuário final, e também devem ser envolvidos nos processos. Não basta projetar com foco apenas no cliente, é preciso projetar também para (e com) o projetista;

Pesquisas e aplicações mercadológicas obtiveram sucesso no uso de metodologias do Design e da Ergonomia na gestão e estratégia de Organizações. Essas 
metodologias podem ser uma ferramenta importante e diferenciada no combate aos problemas inerentes à multidisciplinaridade da EAD.

\subsection{5.}

Objetivo geral

Elaborar, colaborativamente com os atores envolvidos, propostas de gestão e de aperfeiçoamento de processos de produção de material didático da graduação EAD da Fundação Cecierj.

\subsection{6.}

\section{Objetivos específicos}

- Contextualizar a EAD no Brasil, apontando suas particularidades e desafios;

- Relacionar a multidisciplinaridade da EAD com as novas tecnologias e as questões organizacionais;

- Contextualizar os diferentes sistemas produtivos e sua relação com a formação de equipes de trabalho;

- Relacionar as políticas organizacionais de gestão de pessoas e ambientes de trabalho e o seu efeito sobre a produção dos funcionários;

- Descrever as particularidades da montagem de equipes multidisciplinares em EAD;

- Demonstrar o papel do Design e da Ergonomia como ferramentas de mudança aplicáveis em gestão organizacional e sistemas de trabalho;

- Descrever as metodologias do Design a da Ergonomia que buscam atuar nos campos da estratégia, gestão de equipes e interdisciplinaridade, e quais seus diferenciais em relação à Gestão tradicional;

- Demonstrar a importância da participação dos atores envolvidos na construção de modelos organizacionais e melhoria do sistema de trabalho;

- Aferir num estudo de caso, na Fundação Cecierj, a aplicação de metodologias de Design e Ergonomia para melhoria da gestão de equipes multidisciplinares de EAD; 
- Esboçar colaborativamente propostas de melhoria do fluxo de trabalho e de correção de problemas para o contexto do caso estudado, baseadas nos resultados obtidos;

\subsection{7. Justificativa}

Num país com demanda por educação tanto acadêmica quanto profissional como o Brasil, a possibilidade de vencer distâncias e inadequação de horários dá à EAD um papel importante e estratégico. Porém, apesar do crescimento exponencial recente, ainda aquém da sua demanda e do seu potencial.

Cursos de EAD mais extensos apresentam especificidades que dificultam sua implementação. Além disso, parte dos alunos e professores não familiarizados com a Educação a Distância apresentam problemas de adaptação.

Muitas das dificuldades organizacionais relatadas em pesquisas pelas instituições de ensino podem ser minimizadas com a aplicação de técnicas para a construção de uma cultura de trabalho interna e uma melhor interação entre os atores envolvidos.

O Design e a Ergonomia, através de métodos participativos e centrados no ser humano, podem auxiliar as instituições EAD a descobrir suas particularidades, superar desafios organizacionais, melhorar a gestão de pessoas e preparar as equipes multidisciplinares para as exigências tecnológicas e da legislação. Isso poderia reverter a aversão de alguns educadores e educandos, diminuir a evasão de alunos e melhorar a qualidade dos produtos e processos.

O autor desta dissertação trabalha com Educação a Distância há treze anos, sendo dez deles na Fundação Cecierj. A Fundação é uma autarquia estadual responsável pelo Cederj, um consórcio de EAD formado por CEFET, UENF, UERJ, UFF, UFRJ, UFRRJ e UNIRIO que, através de polos espalhados pelo estado, democratiza o acesso à graduação.

Alocado no setor de Mídias Impressas e Digitais, o autor tem acesso ao desenrolar do processo de construção do material didático. O setor engloba desde a adaptação das aulas escritas pelos conteudistas até a entrega do material final em diferentes formatos. Nesta posição, a pesquisa terá como entrevistar as pessoas 
envolvidas e traçar junto a elas um panorama dos processos de elaboração desse material e quais os gargalos de produção.

Atualmente, na Fundação, busca-se aprimorar a produção e a qualidade desse material, melhorando o funcionamento dos processos e do serviço prestado aos 30 mil graduandos atendidos. Logo, uma pesquisa como essa será muito bem recebida e terá apoio de chefias e funcionários.

Esta dissertação é realizada com a crença no potencial da EAD como uma ferramenta de democratização do ensino e na contribuição social que ela pode prover.

\subsection{8.}

\section{Metodologia adotada}

Para realização desta pesquisa foram escolhidos os seguintes métodos e técnicas:

- Levantamento bibliográfico, especialmente nas áreas de EAD, Design e Ergonomia, passando por sistemas de trabalho, Gestão e Cultura Organizacional, entre outros. Isto é feito para a construção de contexto histórico, levantamento do Estado da Arte de conceitos abordados e embasamento teórico para a realização da pesquisa de campo.

- Estudo de caso numa equipe multidisciplinar de material didático para a EAD, que possua as características e particularidades necessárias ao desenvolvimento da pesquisa. Neste estudo serão adotados os seguintes passos:

- Identificação mais profunda de todos os processos e atores envolvidos e do contexto de trabalho;

- Entrevistas estruturadas com os profissionais para obtenção de dados qualitativos sobre o cotidiano de trabalho, relações interpessoais e os principais problemas e dificuldades que essas pessoas sentem no seu cotidiano. 
- Baseado na análise de conteúdo das entrevistas e no contexto encontrado pelo pesquisador, foi realizado um questionário online para validação de opiniões e sugestões surgidas nas entrevistas. Embasando, assim, as propostas colaborativas de melhora no sistema de trabalho abordado.

\section{2.}

\section{Estrutura da dissertação: objetivos e resumo de cada capítulo}

A Tabela 1.1 (abaixo) mostra a organização desta pesquisa em capítulos, segundo o formato recomendado para dissertação.

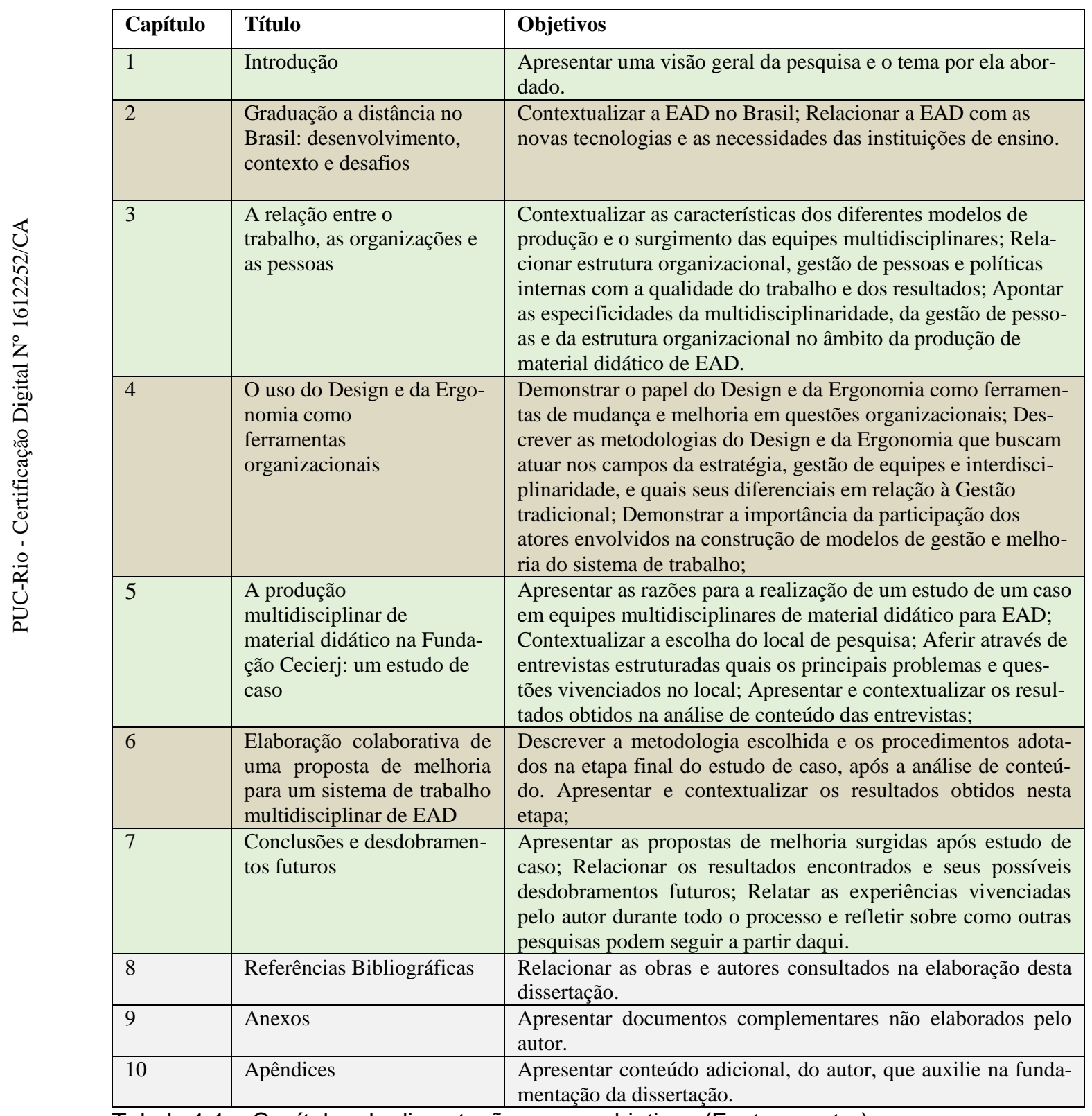

Tabela 1.1 - Capítulos da dissertação e seus objetivos (Fonte: o autor) 


\subsection{1. \\ Resumo dos capítulos}

\section{Capítulo 2 - Graduação a distância no Brasil: desenvolvimento, contex-} to e desafios: aqui, é feito um levantamento histórico e contextual da EAD, de suas origens até sua chegada ao Brasil. Também são traçados o cenário e o caminho percorrido até o estágio atual da modalidade no país. O capítulo aborda ainda o impacto das mudanças tecnológicas e das tecnologias de informação e comunicação no ensino a distância, na necessidade da formação de equipes multidisciplinares e na produção de material didático. Também são apontadas as principais dificuldades encontradas pelas instituições de ensino e como a soma desses fatores se transforma em desafios organizacionais.

Capítulo 3 - A relação entre o trabalho, as organizações e as pessoas: Fez-se uma contextualização dos diferentes modelos de produção, do Taylorismo até a Produção Flexível, e como se chegou aos modelos atuais de trabalho e montagem de equipes. Em seguida, mostra-se como as políticas organizacionais internas (estruturação, cultura, gestão de pessoas e método de liderança, entre outras), podem interferir na qualidade do trabalho e dos serviços prestados. A seguir, considerando o contexto levantado, é ressaltada a importância que se deve dar à montagem de equipes multidisciplinares, especialmente no âmbito da produção de material didático de EAD.

\section{Capítulo 4 - O uso do Design e da Ergonomia como ferramentas orga-} nizacionais: são abordadas as metodologias que versam sobre o Design enquanto ferramenta de mudança, gestão e criação de cultura organizacional. Elas enxergam as organizações e sistemas de trabalho como um projeto de Design. Posteriormente, será abordada a visão e atuação da Ergonomia no âmbito dos sistemas de trabalho e na interface entre homem e organização. Também é feita relação com as metodologias participativas do Design centradas no ser humano, para reafirmar a importância da participação dos profissionais na busca por melhorias no sistema de trabalho multidisciplinar.

Capítulo 5 - A produção multidisciplinar de material didático na Fundação Cecierj: um estudo de caso: aqui, a base teórica e contextual levantada 
nos capítulos anteriores serve como subsídio para um estudo de caso numa instituição que possui produção multidisciplinar de material didático de graduação. A pesquisa prática é importante como oportunidade de avaliar quais métodos, propostas e ferramentas podem funcionar melhor no cenário multidisciplinar de EAD encontrado pelo autor deste trabalho. Neste capítulo, aborda-se a primeira etapa do estudo de caso: entrevistas estruturadas - e posterior análise do seu conteúdo com alguns profissionais que compõem o sistema de trabalho estudado. Os resultados obtidos são analisados e alimentam a etapa seguinte da pesquisa, exposta no próximo capítulo.

\section{Capítulo 6 - Elaboração colaborativa de uma proposta de melhoria pa-} ra um sistema de trabalho multidisciplinar de EAD: aqui, explica-se a escolha pela metodologia utilizada para etapa final da pesquisa no campo - um questionário online para obtenção de respostas e validação de propostas baseadas no contexto encontrado pelo pesquisador e pelos resultados da análise de conteúdo. As respostas aos questionamentos são expostas e avaliadas, subsidiando as propostas de melhoria para a equipe estudada.

Capítulo 7 - Conclusões e desdobramentos futuros: com os resultados obtidos e analisados, são apresentadas as propostas de mudança processual e de cultura de trabalho sugeridas para o Departamento de Material Didático do Cecierj. Também se faz uma breve relação entre o que foi encontrado no estudo de caso e os conceitos teóricos levantados ao longo da pesquisa. Por fim, o autor reflete sobre os possíveis desdobramentos futuros da pesquisa e do objeto estudado, relatando suas experiências e impressões surgidas ao longo da pesquisa. 


\section{2 \\ Graduação a distância no Brasil: desenvolvimento, contex- to e desafios}

Nesta parte da dissertação, será traçado um panorama da EAD: seus primórdios e as mudanças pelas quais passou, paralelamente ao desenvolvimento tecnológico e às políticas públicas. Também será mostrado como sua evolução, somada às mudanças nos cenários educacional e social, resultaram nas especificidades intrínsecas da EAD que são observadas atualmente.

\section{1. \\ EAD no Século XX: da carta ao e-mail}

As origens da EAD remontam à cursos por correspondência, que visavam ampliar, para a população mais pobre, a oferta de educação básica e preparação para o trabalho. Segundo Mugnol (2009, p.337), a Educação a Distância era então vista preconceituosamente como inferior e de nível baixo, voltada apenas para pessoas marginalizadas e com educação atrasada. Estigmas que, para ele, persistem até hoje.

Andrade e Lopes (2012) também destacam que um dos primeiros exemplos brasileiros de EAD que se tem registro envolveu cursos por correspondência:

A modalidade de $\mathrm{EaD}$ surgiu timidamente através de anúncios de jornais no Rio de Janeiro, por volta do ano de 1900. Em seu primeiro momento, a oferta era por cursos profissionalizantes por correspondência, sendo ministrados exclusivamente por professores particulares. Tinha como principal objetivo ampliar as oportunidades educacionais, desenvolvendo alguns cursos voltados para setores de comércio e serviços, permitindo maior acessibilidade ao ensino (...) (ANDRADE; LOPES, 2012, p.3).

Uma das mais antigas instituições a oferecer Educação a Distância no Brasil, o Instituto Universal Brasileiro, foi fundada em 1941 e até hoje oferece cursos técnicos, profissionalizantes e supletivos utilizando a correspondência como principal ferramenta. 
Ao longo do século XX, a Educação a Distância foi se consolidando graças a avanços como o telefone e o rádio. O crescimento da EAD sempre esteve intimamente ligado ao desenvolvimento tecnológico. Mugnol (2009, p.337) afirma que, ainda no fim século XIX, o avanço da tecnologia já tornava mais claro o potencial de desenvolvimento da EAD e ajudava a multiplicar iniciativas em vários países da Europa, América e África. Segundo Saraiva (1996):

O aperfeiçoamento dos serviços de correio, a agilização dos meios de transporte e, sobretudo, o desenvolvimento tecnológico aplicado ao campo da comunicação e da informação influíram decisivamente nos destinos da educação a distância (SARAIVA, 1996, p.19).

No Brasil, um dos marcos do início da EAD se deu na década de 1920, através da Rádio Sociedade do Rio de Janeiro. Comandada na época por Roquette-Pinto, a emissora utilizou um plano sistemático educacional de radiodifusão como forma de ampliar o acesso à educação (OLIVEIRA, 2013, p.3). Andrade e Lopes (2012, p.4), lembram ainda da Universidade no Ar (1946), vinculada ao SENAC, e do MOBRAL (1959), ligado ao Governo Federal. Ambos foram importantes exemplos do uso do rádio como distribuidor de conteúdo educativo. Permitia-se, através dessas iniciativas, o compartilhamento de material educacional e cultural para todas as classes sociais e etárias. Isso foi essencial para a consolidação da participação Brasileira na EAD (MUGNOL, 2009). É importante ressaltar que, em alguns casos, já se utilizava o material impresso concomitantemente ao conteúdo via rádio, como forma de enriquecer e organizar a EAD através de mídias complementares:

Depois da primeira metade do século XX, observam-se programas com base na propagação da construção de conhecimentos, fazendo uso de sistemas de radiodifusão e uma articulação entre o rádio e o material impresso na organização do currículo escolar (ANDRADE; LOPES, 2012, p.4).

Outras iniciativas que utilizavam o rádio, como o Projeto Minerva e o MEB (Movimento de Educação de Base), tiveram curta duração e pouco sucesso nas décadas de 1960 e 1970. Esses projetos sofreram com alta evasão e problemas de formatação do conteúdo. Nas décadas seguintes, houve uma mudança de paradigma, e as produções passam a oferecer conteúdos menos instrucionais e mais 
reflexivos, onde o ouvinte era levado a pensar sobre a sua condição de cidadão (ANDRADE; LOPES, 2012, p.4).

A partir da década de 1970, na Europa, surgem instituições focadas em EAD que levaram os estudos sobre ferramentas e metodologias a um novo patamar, como a Open University da Inglaterra e a UNED, na Espanha:

Um dos marcos históricos da Educação a distância foi a criação da Universidade Aberta de Londres em 1970, a Open University, que contribuiu decisivamente para o desenvolvimento de métodos e técnicas que serviram para caracterizar os diferentes modelos de EAD existentes. Além disso, contribuiu também para o desenvolvimento de tecnologias que deram mais solidez aos processos educacionais a distância e para a utilização massiva da mídia (MUGNOL, 2009, p.338).

Andrade e Lopes (2012), também frisam a importância da Open University no desenvolvimento da Educação a Distância:

Uma das mais importantes universidades criadas é a Open University, do Reino Unido. A experiência dessa universidade em EaD passou a ser referência para o mundo, tanto por sua qualidade quanto pela metodologia de desenvolvimento de seus cursos, articulando as tecnologias de comunicação e preocupando-se com as ações pedagógicas (ANDRADE; LOPES, 2012, p.11).

Na mesma época, a teleducação, aliada ao material impresso, passa a articular e integrar o áudio, o videocassete, a transmissão de rádio e a televisão (SARAIVA, 1996, p.19 e 22). No âmbito do Brasil, Barreto (2009, p.451 e 452) destaca a série Telecurso, da Fundação Roberto Marinho, o Salto para o Futuro, da TVE Brasil, e a TV Escola, do MEC. A integração desses fatores potencializou a evolução que a EAD já experimentava ao longo do século XX:

Observa-se um notável crescimento quantitativo. Aumenta o número de países, de instituições, de cursos, de alunos, de estudos. Em segundo lugar, há uma significativa alteração qualitativa: novas metodologias e técnicas são incorporadas, novos e mais complexos cursos são desenvolvidos, novos horizontes abrem-se para a utilização da educação a distância (SARAIVA, 1996, p.19).

A EAD brasileira recebeu maior impulso ao ser encampada pelo poder público, no início dos anos 1990. Isso ocorreu através de programas a distância de formação continuada de professores nas redes municipais e estaduais (MUGNOL, 2009, p.344). 
Para Saraiva (1996, p.24), com a criação do Sistema Nacional de Educação a Distância, através do decreto $\mathrm{n}^{\circ} 1.237$, de 1994, o governo brasileiro tomava as primeiras medidas para a formulação de uma política nacional para o setor.

Em 1996, com a publicação de Lei de Diretrizes e Bases da Educação Brasileira (LDB), a Educação a Distância se torna efetivamente uma política pública. Arruda e Arruda (2015, p.323) afirmam que se, historicamente, a EAD brasileira começa no século XIX, seu marco regulatório só acontece efetivamente com a promulgação da LDB, pela lei no 9.394 de 1996.

A Lei de Diretrizes e Bases da Educação versa que é obrigação do Estado incentivar o desenvolvimento e veiculação de programas de EAD em todos os níveis e modalidades de ensino e de educação continuada. Além disso, cabe ao Estado também regular, controlar e credenciar instituições provedoras de Educação a Distância (BRASIL, 1996). No mesmo ano, criou-se no Ministério da Educação a SEED (Secretaria de Educação a Distância), que seria responsável, nos anos seguintes, por criar e manter programas e iniciativas fomentadores da EAD brasileira: ProInfo, TV Escola, Banco Internacional de Objetos Educacionais e Portal do Professor, entre outros (GOMES, 2013, p.14).

Além da redação original da $\mathrm{LDB}$, a EAD também teve destaque no PNE (Plano Nacional da Educação) aprovado através da Lei $\mathrm{n}^{\circ} 10.172$, de 2001. O PNE tem duração de dez anos e deve servir de parâmetro para Estados, Municípios e Sociedade Civil construírem seus planos decenais (BRASIL, 2001). No PNE 2001-2010, o Governo Federal deixava claro que considerava a EAD uma solução para os baixos índices de acesso aos cursos superiores:

No processo de universalização e democratização do ensino, especialmente no Brasil, onde os déficits educativos e as desigualdades regionais são tão elevados, os desafios educacionais existentes podem ter, na educação a distância, um meio auxiliar de indiscutível eficácia (BRASIL, 2001).

Arruda e Arruda (2012) também apontam a importância dada à EAD no texto da PNE 2001-2010:

A interpretação de que a $\mathrm{EaD}$ permite uma ampliação de vagas e ofertas em menor tempo pode ser observada no PNE 2001- 2010, uma vez que o termo Educação à Distância aparece nada menos que 29 vezes (...) a EaD, sob essa perspectiva do PNE 2001-2010, parece ser a resposta para os males que acometeram a educação brasileira ao longo dos últimos séculos (ARRUDA; ARRUDA, 2015, p.324 e 325). 
Gomes (2009) destaca que uma intervenção digna de nota foi a portaria do MEC $\mathrm{n}^{\circ} 4.059$, de 2004. Ela atualizou normas anteriores e passou a permitir a oferta de disciplinas semipresenciais em cursos superiores reconhecidos. A tutoria dessas disciplinas passaria a exigir docentes qualificados com carga horária específica para os momentos presenciais e a distância. A portaria também determinava que as avaliações seriam obrigatoriamente presenciais.

Outra iniciativa governamental de fomento da EAD foi a criação do Sistema UAB (Universidade Aberta do Brasil), através do decreto $\mathrm{n}^{\circ} 5.800$, de 8 de junho de 2006. Segundo Gomes (2013, p.14 e 15), a criação da UAB se deu baseada na experiência dos consórcios nacionais formados por Universidades Públicas. Os consórcios oferecem cursos superiores e de formação continuada. Como exemplos, o autor cita a UNIREDE (que possui setenta instituições públicas de ensino participantes) e o Projeto Veredas, da UFMG. O Consórcio CEDERJ, gerido pela Fundação Cecierj, também funciona da mesma maneira, no âmbito do Estado do Rio de Janeiro.

Para Gomes (2009), os objetivos do decreto que cria a UAB:

(...) envolvem, em particular, o oferecimento prioritário de cursos de licenciatura e formação inicial de professores da educação básica, de capacitação de dirigentes, gestores e trabalhadores em educação básica a oferta de cursos superiores nas diferentes áreas do conhecimento (...) em coerência com o que regulamentou o artigo 80 da LDB, enfatiza a articulação das instituições públicas de ensino superior com os pólos de apoio presencial, destinados a apoiar de modo descentralizado as atividades pedagógicas e administrativas relativas aos cursos e programas (GOMES, 2009 , p.23).

Apesar do fomento à EAD, o trecho da LDB de 1996 referente ao funcionamento da Educação a Distância no país só foi feito no decreto $\mathrm{n}^{\circ} 5.622$ do Poder Executivo Federal, datado de 2005. Neste decreto estão as regras em vigência até o presente momento. A importância dessa publicação foi ressaltada por Mugnol (2009):

O Decreto n. 5.622, de 19 de dezembro de 2005, estabeleceu o reconhecimento no sistema oficial de ensino dos cursos ofertados na modalidade por Instituições credenciadas pelo MEC. Com isso expande-se o processo de produção de conhecimento acerca da EAD no Brasil e novos projetos de cursos começam a ser desenvolvidos, propondo-se inicialmente a atender interesses e necessidades específicas de formação de professores da Educação Básica e da Educação Superior (MUGNOL, 2009, p.345). 
Andrade e Lopes (2012, p.10) sublinham que a LDB direcionou um novo olhar para a EAD, que passou a contar com os requisitos para a realização de exames pela União e registros de diplomas relativos a cursos de Educação a Distância.

No que tange os cursos superiores, a legislação passou a permitir o oferecimento a distância de formações profissionais tecnológicas, programas e cursos de educação superior sequenciais e de graduação. Também foram permitidos na pósgraduação: especialização, mestrado e doutorado. Na prática, a lei exige que os cursos superiores, mesmo os ditos $100 \%$ a distância, sejam semipresenciais. Isso ocorre, pois é compulsória a presença do aluno na sede da IES ou nos polos de apoio presencial (que também são obrigatórios) credenciados. Os momentos presenciais ocorrem nas provas de avaliação e, quando previstos, em estágios obrigatórios, defesas de trabalhos de conclusão de curso e atividades relacionadas a laboratórios (BRASIL, 2005).

Já os cursos livres, que não dependem de autorização de um órgão legal para serem oferecidos, se constituem numa modalidade mais simples de ser ofertada, muitas vezes não exigindo apoio presencial de tutores, polos e nem integração com material impresso. Segundo o Censo EAD.br de 2014, os cursos livres representam $80 \%$ das formações oferecidas e $77 \%$ do total de vagas a distância do país (ABED, 2015, p.8).

Vários estudiosos da EAD, inclusive alguns citados neste trabalho, demonstram preocupação sobre a legislação vigente e a atuação governamental no Brasil. Há questionamentos sobre influências políticas e mercadológicas e sobre o seu efeito pedagógico na expansão da EAD nacional. Alguns autores defendem que o Governo é muito permissivo, enquanto outros afirmam que ele é muito restritivo. Como este não é o foco desta dissertação, preferiu-se não abordar essas questões. A legislação é citada nesta pesquisa apenas para contextualizar as características do trabalho e das demandas na produção de material didático de educação a distância.

A $\operatorname{ABED}(2015$, p.18) divide as ações diretas em EAD em três categorias: 


\begin{tabular}{|l|l|}
\hline \multicolumn{1}{|c|}{ Categoria } & \multicolumn{1}{c|}{ Características } \\
\hline Cursos totalmente a distância & $\begin{array}{l}\text { Mais de 70\% do conteúdo desenvolvido para disciplinas a distância. } \\
\text { Estudo por meio de materiais impressos, áudio, vídeo; conteúdo } \\
\text { emitido via satélite ou por tecnologias digitais, como computador, } \\
\text { tablets e celulares }\end{array}$ \\
\hline $\begin{array}{l}\text { Cursos blended, híbridos ou } \\
\text { semipresenciais }\end{array}$ & $\begin{array}{l}\text { Combinam atividades presenciais e a distância, com proporção varia- } \\
\text { da de 30\% a 70\% de uma forma em relação a outra. }\end{array}$ \\
\hline $\begin{array}{l}\text { Disciplinas realizadas a } \\
\text { distância }\end{array}$ & $\begin{array}{l}\text { Cursos de graduação autorizados e presenciais, correspondendo a até } \\
\text { 20\% do currículo na modalidade EAD, de acordo com a legislação } \\
\text { nacional. }\end{array}$ \\
\hline
\end{tabular}

Tabela 2.1 - Categorias de oferecimento de ensino a distância. (Fonte: Censo ABED, 2015)

Assim, os cursos de graduação EAD, mais extensos, podem exigir estrutura e processos de funcionamento mais complexos. Por exemplo, precisam de polos presenciais e de tutoria. Seu funcionamento depende de uma cadeia maior de eventos e de pessoas interagindo. É com base nisso, também, que a produção de material didático de graduação por equipes multidisciplinares é o recorte desta pesquisa.

E todos esses desafios só aumentaram no Século XXI, graças a fatores que serão expostos a seguir.

\section{2.}

\section{Século XXI: o salto da modalidade a distância}

Do fim do Século XX até hoje, a EAD brasileira viveu uma explosão, amplificada pelas políticas públicas já relatadas e por uma série de mudanças tecnológicas.

Segundo Censo da Educação Superior de 2014, a graduação a distância é responsável por apenas 3,9\% dos cursos superiores do Brasil. Apesar disso, a graduação EAD cresceu 35,3\% no número de cursos oferecidos entre 2010 e 2013. Nesse mesmo período, registrou aumento de $24 \%$ nas matrículas e de $35,5 \%$ no ingresso de alunos (BRASIL, 2015, p.18). 


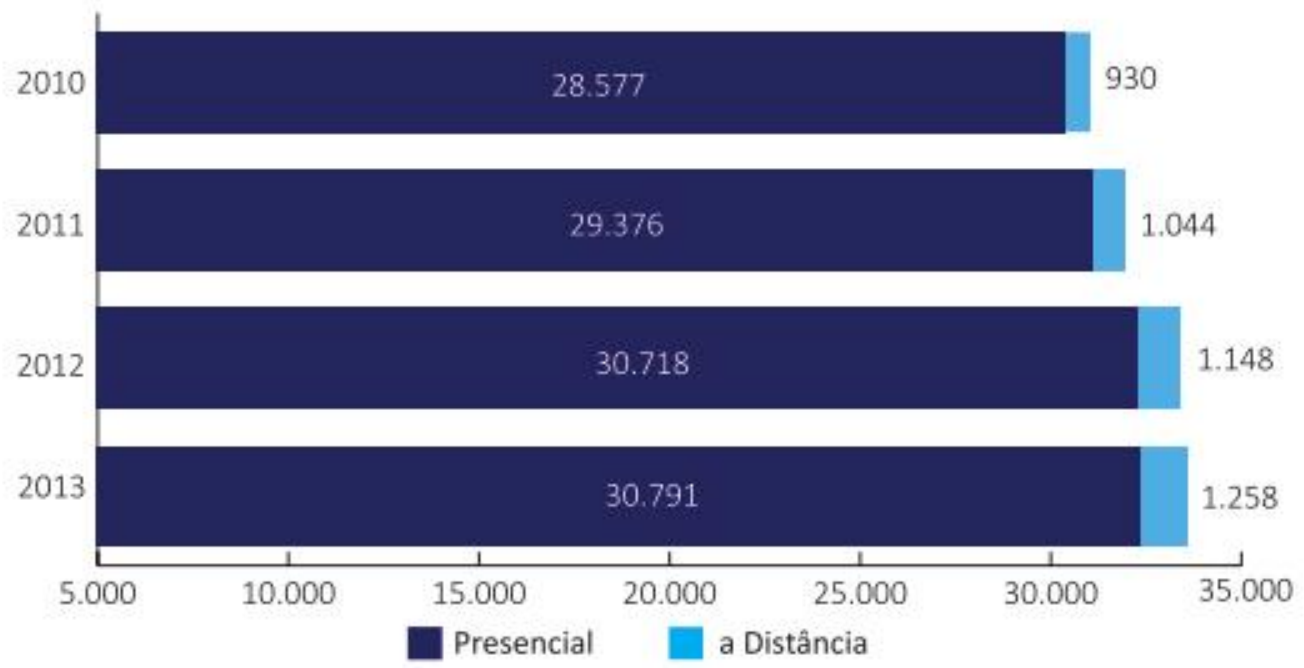

Figura 2.1 - Evolução do Número de Cursos de Graduação, segundo a Modalidade de Ensino, entre 2010 e 2013 (Fonte: Censo da Educação Superior - Inep/Deed)

Voltando o olhar para a década passada, percebe-se que, entre 2003 e 2013, a EAD superior registrou 2.200\% de aumento (BRASIL, 2015), passando de menos de 50.000 matrículas para mais de 1,1 milhão.

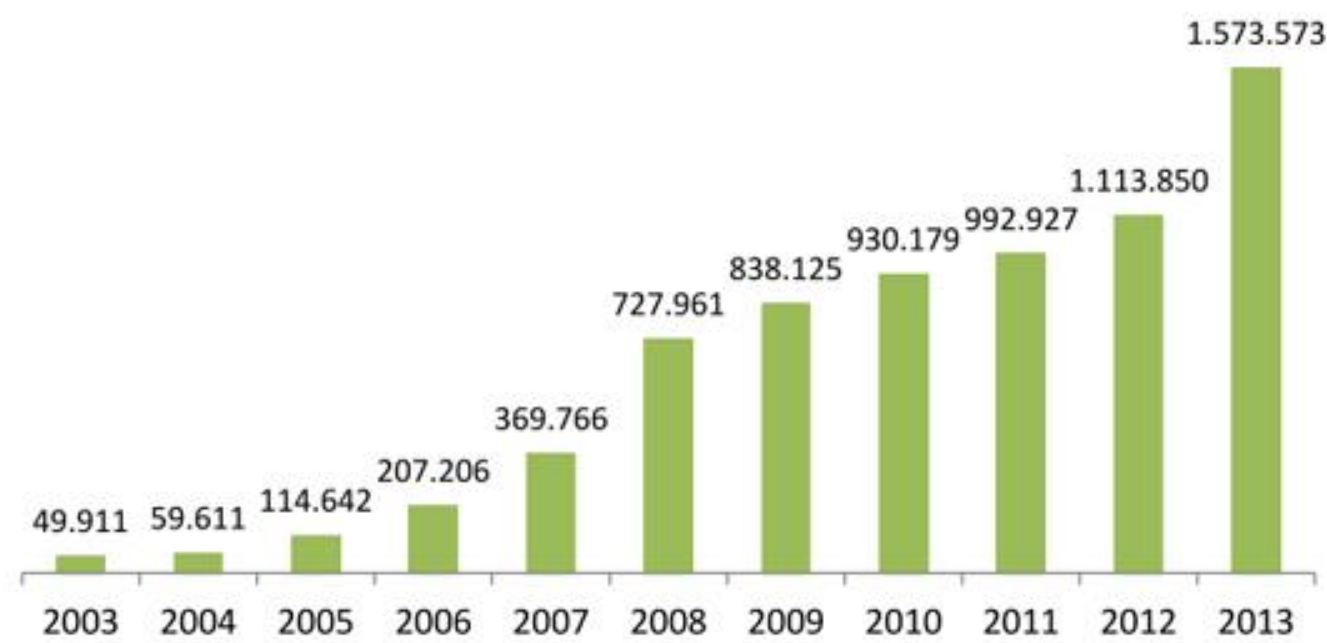

Figura 2.2 - Matrículas na graduação a distância, em termos absolutos (Fonte: Censo da Educação Superior- Inep/Mec)

Na avaliação governamental do Balanço Social SESu 2003-2014, esse crescimento é fruto da demanda reprimida e do fomento público à Educação a Distância: 
Outra medida com alto potencial de variedade da oferta é o fomento à educação a distância, que apresenta ainda outras vantagens como o baixo custo, a flexibilidade de horários e o alcance praticamente universal. (...) esse extraordinário crescimento (da ordem de $2200 \%$ ) comprova, de um lado, a existência de uma forte demanda reprimida por modelos alternativos de oferta de educação superior, e, de outro, a superação do preconceito histórico com a modalidade, fruto das políticas do MEC nesse sentido (BRASIL, 2015, p.21).

Esse rápido crescimento exponencial pode ter impactado a formação das equipes que produzem material didático. Litto $(2009$, p.14) acredita que essa expansão pode significar que muitos dos profissionais que trabalham com EAD não tiveram um aprendizado "formal" (aspas do próprio autor) na área. De qualquer maneira, as políticas públicas não são a única explicação para esse crescimento expressivo. É preciso abordar também a relação entre EAD e o desenvolvimento das TICs (Tecnologias da Informação e Comunicação) e a popularização da internet. Nas palavras de Mugnol (2009):

\footnotetext{
Paralelo às iniciativas no campo da normatização legal, aprofunda-se o desenvolvimento e a utilização das tecnologias de comunicação e informação, inclusive com o desenvolvimento de equipamentos tecnológicos e softwares especialmente voltados para a educação a distância (MUGNOL, 2009, p.345 e 346).
}

No próximo subcapítulo (2.3), serão abordadas as características e demandas da relação entre as TICs, as novas tecnologias e a EAD no trabalho e na formação de equipes multidisciplinares de produção de material didático.

\section{3. \\ EAD, TICs e inovações tecnológicas}

A popularização da internet, a inclusão digital e as inovações tecnológicas mudaram os paradigmas da Educação em geral. Andrade e Lopes (2012, p.7), citando a visão de Litto (2009), afirmam que a internet permitiu o crescimento dos veículos que norteiam a educação. Isso fez que os limites entre disciplinas, instituições e locais geográficos se tornem cada vez menos perceptivos. Para Saraiva (1996, p.19), a utilização de novas tecnologias propicia a ampliação e diversificação dos programas, numa interação quase presencial entre professores e alunos. Formiga (2009, p. 43) diz que, através das TICs, os modelos de aprendizagem "ultrapassaram o universo limitado dos educadores e invadem todas as células da 
vida social e econômica". Já Mugnol (2009) sublinha a relação da EAD com a multimídia e o computador:

O surgimento do computador como meio mais rápido para transportar a palavra escrita mudou não só o veículo de distribuição do ensino, mas a forma de mediação. A multimídia, que trabalha com as múltiplas linguagens (sonora, audiovisual e iconográfica), amplia as possibilidades de ensino aprendizagem e pode, desde que adequadamente projetada, atender a uma demanda social por educação (MUGNOL, 2009, p.346).

A Educação a Distância se caracteriza, desde seus primórdios, pelo uso de tecnologias de informação e comunicação para vencer o hiato entre professor e aluno. Partindo de aulas por correspondência, livros didáticos e radiodifusão, hoje a EAD conta com tecnologias como streaming de vídeo, Realidade Aumentada, TV Digital interativa e Ambientes Virtuais de Aprendizagem. Segundo Behar (2009, p.16), a EAD pode ser definida como uma aprendizagem organizada, em que há separação física entre professores e alunos e a interação entre eles se realiza através de alguma tecnologia de midiatização.

A própria definição governamental sobre a EAD, presente no decreto 5.622, segue pelo mesmo caminho:

Para os fins deste Decreto, caracteriza-se a educação a distância como modalidade educacional na qual a mediação didático-pedagógica nos processos de ensino e aprendizagem ocorre com a utilização de meios e tecnologias de informação e comunicação, com estudantes e professores desenvolvendo atividades educativas em lugares ou tempos diversos (BRASIL, 2005).

Outros autores, ao definirem a Educação a Distância, também citam o papel intrínseco dos recursos de mídia como ponte entre professores e alunos. Andrade e Lopes (2012, p.2), analisando as definições de Moran (2007) e Freitas (2005), comentam que a terminologia EAD é utilizada em programas e processos de ensino e aprendizagem onde professores e alunos não estão unidos fisicamente, mas interligados por diferentes tipos de tecnologias. É também uma modalidade de ensino independente, em que o estudante tem alguma autonomia em relação ao tempo e local de estudo.

Farias (2013, p.16) define a EAD como um sistema de aprendizagem centrado no aluno, onde o acesso às fontes de ensino ocorre através de dispositivos 
eletrônicos e multimídia, os quais fornecem independência de tempo e/ou espaço, assim como uma maior interação entre os alunos, professores e/ou tutores.

Mugnol (2009, p.337 e 338) lembra que o desenvolvimento das telecomunicações com meios interativos e a popularização do computador e da internet trouxeram novas perspectivas. Além disso, tornaram-se ferramentas fundamentais para a contínua evolução da EAD. O crescimento da internet também se deu, segundo Formiga (2009), por ser uma plataforma facilitadora representada pelas TICs. Ainda no final do século XX, já era possível medir o impacto dessas mudanças no campo da Educação a Distância, como frisou Saraiva (1996):

As tecnologias da informação aplicadas à EAD proporcionam maior flexibilidade e acessibilidade à oferta educativa, fazendo-as avançar na direção de redes de distribuição de conhecimentos e de métodos de aprendizagem inovadores, revolucionando conceitos tradicionais e contribuindo para a criação dos sistemas educacionais do futuro (SARAIVA, 1996, p.27).

Formiga (2009, p.39) reafirma que a EAD está intrinsecamente ligada às TICs pelo seu dinamismo e a capacidade de inovação. Segundo ele, a sociedade da informação "reflete-se na EAD pela apropriação célere dos conceitos e inovações, que moldam a mídia e se refletem na própria EAD”. Mugnol (2009, p. 340), diz que os materiais didáticos de qualidade e a mediação tecnológica dos meios de comunicação e informação colaboram para o bom desempenho do professor na educação a distância. Teixeira e Weschenfelder (2013) afirmam que se pode falar de uma EAD antes e outra depois da internet e das tecnologias ligadas a ela:

A aplicação de novas tecnologias na educação a distância (EAD), especialmente aquelas ligadas à internet, vem modificando o panorama dentro deste campo de tal modo que, seguramente, pode-se falar de uma EAD antes e depois da internet. Antes da internet tinha-se uma EAD que utilizava apenas tecnologias de comunicação de "um-para-muitos" (rádio, TV) ou de "um-para-um" (ensino por correspondência). Via internet há as três possibilidades de comunicação reunidas numa só mídia: "um-para-muitos", "um-para-um" e, sobretudo, "muitos-para-muitos" (TEIXEIRA; WESCHENFELDER, 2013, p.7 e 8).

Para Formiga (2009, p.43), os novos conceitos de aprendizagem coincidem com a inovação presente em todos os aspectos da vida humana. EAD e TICs estão unidas, uma vez que se tornam indispensáveis para as práticas concretas e eficazes de aprendizagem. Estamos saindo de uma EAD massiva, de produto pronto, igual para todos, para modelos flexíveis, que combinam o individual com momentos 
coletivos e colaborativos. As tecnologias $W E B 2.0$ facilitam a aprendizagem entre colegas e torna o processo mais aberto, ágil e intuitivo (MORAN, 2012).

Nunes $(2009$, p.2) lembra que para maximizar as vantagens da educação a distância, é preciso utilizar um arsenal específico, como meios de comunicação, técnicas de ensino, metodologias de aprendizagem e processos de tutoria. O uso de multimeios, mais do que um diferencial ou atrativo, é fundamental na construção da interação em EAD. Como frisaram Oliveira (2013) e Andrade e Lopes (2012):

Para Carneiro (2001), quando se utilizam várias mídias, conseguem-se abordagens diferentes, representações diferentes e focos diferentes, potencializando a aprendizagem. Multimídia significa muitos meios (KAMPFF; DIAS, 2003). Na educação, a multimídia passa a ser uma estratégia na utilização de múltiplos recursos que contemplam diferentes percepções (OLIVEIRA, 2013, p.7).

Nas últimas duas décadas, diante da enorme evolução das TIC, gerando uma grande diversidade em relação aos programas de formação a distância, principalmente aqueles monitorados por computadores ou satélites, constatou-se um grande alargamento na interatividade, no que se refere à relação entre professores e alunos na EaD. Observou-se a possibilidade de acesso a todos os tipos de informação digitalizada, tais como, texto, sons, gráficos, imagens fixas e sintéticas, além da autogestão do acesso ao conhecimento pelo educando(ANDRADE; LOPES, 2012, p.10).

Considerando-se essas visões, é inegável a relação entre EAD e as TICs. No mesmo período do crescimento de $2200 \%$ da educação superior brasileira, vários paradigmas sociais e educacionais foram quebrados por uma série de inovações tecnológicas, como smartphones, tablets, e-books, e-readers, redes sociais, vídeo chat, sistemas de gestão de ensino, entre outros (Tabela 2.2).

\begin{tabular}{|c|c|}
\hline Mudança tecnológica & Ano de surgimento \\
\hline Moodle 1.0 & 2002 \\
\hline Skype & 2003 \\
\hline Orkut e Facebook & 2004 \\
\hline Youtube & 2005 \\
\hline Iphone e Kindle e-reader & 2007 \\
\hline Android OS e Internet 3G (no Brasil) & 2008 \\
\hline Ipad & 2010 \\
\hline Internet 4G (no Brasil) & 2012 \\
\hline
\end{tabular}

Tabela 2.2 - Algumas mudanças tecnológicas surgidas no período de forte crescimento da EAD brasileira. (Fonte: o autor, com base na pesquisa realizada) 
Como medir no nosso cotidiano, por exemplo, as mudanças que as redes sociais trouxeram? Segundo matéria publicada no site do jornal O Globo, datada de 20 de maio de 2015, os brasileiros gastam em média 650 horas por mês em redes sociais. Este número nos faz líderes mundiais nesse quesito e é $60 \%$ maior que a média mundial (OTONI, 2015). É claro que uma inovação tão popular também teria o seu reflexo e seria aplicada na Educação a Distância:

$\mathrm{O}$ advento na Web de atividades denominadas social networking tem sido visto como de grande importância para a aprendizagem. Oferecendo mais possibilidades para a colaboração e o compartilhamento de conhecimentos entre alunos e docentes, a Web 2.0 representa a segunda geração da Web, com interatividade aumentada, oferecimento de serviços de hospedagem on-line de conteúdos, além de programas e 'suítes' que aumentam a produtividade. Esses 'softwares sociais', às vezes em forma de multimídia, fornecem ferramentas úteis para a aprendizagem, como agendas online e organizadores pessoais, ambientes para colaboração, gerenciamento de projetos e recursos em vídeo (como YouTube e TeacherTube) (LITTO, 2009, p.17).

Outro recurso a ser destacado no campo da EaD são as redes sociais. Barcelos, Passerino e Behar (2011), em um estudo envolvendo a formação de professores, focam a possibilidade do uso das redes sociais, enquanto ambiente pessoal de aprendizagem e, possui um grande potencial para apoiar processos de formação dos professores, possibilitando cooperação, interação entre seus pares, representando um importante recurso para apoiar atividades educacionais na EaD (ANDRADE; LOPES, 2012, p.9).

Citando outro exemplo, a maioria das IES usa maciçamente os AVAs (Ambientes Virtuais de Aprendizagem) para entrega de conteúdo e comunicação com os alunos (ABED, 2015). O Moodle, citado na Tabela 2.2, é um LMS (Learning Management System) gratuito, livre e aberto, que permite a criação de ambientes com várias funcionalidades para o semipresencial e a distância. Segundo a ABED (2015), o AVA é a principal ferramenta da EAD brasileira para compartilhamento de material e comunicação com os alunos (Figura 2.3). É interessante notar que outras inovações surgidas no período, como o Facebook e o Google + são citados, apesar desta não ser a sua atividade-fim.

Segundo Andrade e Lopes (2012, p.8) educar em AVAs requer maior dedicação do professor e apoio da equipe técnica-pedagógica. O curso precisa de mais tempo de elaboração e de um acompanhamento mais sólido de todo o processo. Os autores, analisando as afirmações de Silva (2003), justificam o uso do AVA 
pelo ganho dos alunos com a personalização da aprendizagem, adaptando-a ao seu ritmo de vida. Além disso, a grade curricular e os tipos de atividades se tornam mais flexíveis.

\begin{tabular}{|l|l|}
\hline Opç̃es & Respostas \\
\hline $\begin{array}{l}\text { Ambiente virtual de aprendizagem } \\
\text { (AVA) gratuito (Moodle, Teleduc, Sakai } \\
\text { etc.), locado (Blackboard, Webaula, } \\
\text { Aulanet, WEBCT etc.) ou próprio } \\
\text { (desenvolvido pela instituição) }\end{array}$ & 244 \\
\hline $\begin{array}{l}\text { E-mail ou listas/grupos de e-mail } \\
\text { Grupos em redes sociais (Facebook } \\
\text { Google + etc.) }\end{array}$ & 78 \\
\hline $\begin{array}{l}\text { Grupos de chat (WhatsApp, Telegram } \\
\text { etc.) }\end{array}$ & 27 \\
\hline Blogs & 22 \\
\hline
\end{tabular}

\begin{tabular}{|l|l|}
\hline Opções & Respostas \\
\hline $\begin{array}{l}\text { Canais da Wikimedia Foundation } \\
\text { (Wikiversidade, Wikipédia Commons } \\
\text { etc.) }\end{array}$ & 3 \\
\hline Google Drive & 31 \\
\hline Dropbox & 16 \\
\hline Scribd & 1 \\
\hline Flickr & 2 \\
\hline YouTube $^{\circ}$ & 58 \\
\hline Vimeo $^{\text {TM }}$ & 10 \\
\hline Outro(s) $^{\circ}$ & 10 \\
\hline
\end{tabular}

Figura 2.3 - Ferramentas utilizadas para o compartilhamento de materiais com os alunos (Fonte: ABED, 2015)

Como forma de ilustrar a complexidade técnica que envolve a construção de um curso de graduação em EAD, a Tabela 2.3 lista algumas das opções e características de LMS a serem consideradas pelas IES:

\begin{tabular}{|l|l|}
\hline \multicolumn{1}{|c|}{ Opções de LMS para cursos via Web } & \multicolumn{1}{c|}{ Características } \\
\hline $\begin{array}{l}\text { 1) desenvolver, com recursos humanos locais, o } \\
\text { software apropriado para gerenciar o conteúdo } \\
\text { instrucional e as atividades de aprendizagem }\end{array}$ & $\begin{array}{l}\text { * garantir a manutenção, 24 horas por dia, sete dias } \\
\text { por semana (24/7) da tecnologia necessária para o } \\
\text { acesso ininterrupto ao portal por parte de alunos, } \\
\text { professores e administradores; }\end{array}$ \\
\hline $\begin{array}{l}\text { 2) construir, com uma equipe local, um sistema de } \\
\text { gerenciamento de aprendizagem baseado em sof- } \\
\text { tware de fonte aberta (Moodle e TelEduc, etc.) }\end{array}$ & $\begin{array}{l}\text { * muito material e referencial fornecido gratuita- } \\
\text { mente por comunidades de praticantes voluntários; } \\
\text { * desafio de manutenção do portal 24/7; }\end{array}$ \\
\hline $\begin{array}{l}\text { 3) aproveitar o software de fonte aberta oferecido } \\
\text { por empresas que não cobram pela licença de uso, } \\
\text { mas pelo suporte (MoodleRooms, Sun e IBM); }\end{array}$ & $\begin{array}{l}\text { * O suporte tecnológico, caso solicitado pela insti- } \\
\text { tuição, terá que ser pago; }\end{array}$ \\
\hline $\begin{array}{l}\text { 4) contratar empresas que ofereçam serviços de uso } \\
\text { de sua 'plataforma' (sistema de gerenciamento de } \\
\text { aprendizagem) }\end{array}$ & $\begin{array}{l}\text { * A "hospedagem" dessa plataforma e de todo o } \\
\text { conteúdo dos cursos se dará nos servidores da } \\
\text { empresa, acessíveis via Web de qualquer parte do } \\
\text { mundo. }\end{array}$ \\
\hline
\end{tabular}

Tabela 2.3 - Opções para o uso de LMS em cursos via Web (Fonte: O autor, baseado em LITTO, 2009)

A velocidade do desenvolvimento tecnológico e da sua adoção por parte dos alunos explica a visão de Litto (2009, p.18), quando afirma que, no passado, os dirigentes das instituições de ensino determinavam as tecnologias com as quais os alunos aprenderiam. Nos dias atuais, segundo ele, os dirigentes buscam se adaptar às tecnologias que os alunos já possuem. 
Isso pode ficar mais explícito se olharmos o caso do uso educacional dos dispositivos móveis. Segundo matéria publicada no sítio eletrônico do jornal O Globo em 2016, 38,3 milhões de brasileiros acessam a internet através de celulares ou tablets, sendo que 8,7 milhões deles utilizam apenas dispositivos móveis para se conectar. Além disso, os brasileiros são líderes no uso de smartphones na América Latina e ocupam o sexto lugar no ranking mundial, segundo matéria publicada pelo jornal Diário do Nordeste. Ainda assim, no Censo 2014 da ABED (2015, p.9), entre 254 instituições pesquisadas, 174 (68,5\%) ainda não haviam incorporado dispositivos móveis nos cursos de EAD que ofereciam. Este cenário exemplifica a necessidade contínua de investimento das IES em inovação. A maioria das instituições consultadas pelo mesmo censo declarou que investia em tecnologia, inovação e na produção de novos cursos ou módulos (ABED, 2015, p.8).

Mas, além das dificuldades e demandas tecnológicas, é preciso lembrar que a EAD também tem questões pedagógicas inerentes que influem na produção de seu material didático. Essa questão será abordada a seguir.

\section{4. \\ A tecnologia e as questões pedagógicas na EAD}

Coutinho (2009), considerando as experiências na capacitação de professores para cursos online, diz que a maior dificuldade dos docentes não está na utilização das ferramentas, mas na elaboração pedagógica, que demanda mais tempo de preparo e traz dificuldades na criação das estratégias diversificadas que a EAD exige.

Moran (2013) lembra que as tecnologias trazem muitas possibilidades, mas sem um trabalho paralelo sólido e constante de formação, passa a ser subutilizada pelos professores após a empolgação inicial.

Segundo Mattar (2009, p.112), a interatividade é um conceito complexo, ainda mais no contexto da educação. Em termos de EAD, é ainda mais complicado, já que "diversos agentes interagem de diferentes maneiras, utilizando inúmeras ferramentas e com expectativas e objetivos bastante distintos". O desenvolvimento constante da tecnologia traz cotidianamente novas formas de interação. Isso obriga os profissionais e estudiosos da área a revisitar o conceito com frequência. 
Um curso de graduação a distância, por sua complexidade, talvez não possa abrir mão de ser dialógico. Palange (2009, p.379 e 380), citando as definições de Porto (2006), lembra que a educação é um processo comunicacional em que alunos e professores estabelecem uma relação educativa dialógica e plural. Ao preparar um curso, o educador organiza o desenho pedagógico a partir de sua visão de educação e comunicação. Assim, é necessário construir a possibilidade de que o outro fale, se expresse, tenha voz.

Segundo Formiga (2009, p.43), o papel das TICs e a valorização da inovação criam um novo paradigma de aprendizagem flexível. Para os professores, caberá não mais a simples transmissão de conhecimento, mas deslocar sua competência para o incentivo à aprendizagem, para raciocinar, pensar, falar e escrever melhor. O professor passa a ser um eterno aprendiz ao dividir e compartilhar seus conhecimentos e, sobretudo, suas dúvidas.

\begin{tabular}{l|l}
\hline \multicolumn{2}{c}{ Da educação à aprendizagem } \\
\hline Antigo paradigma & Novo paradigma \\
\hline Instalaçóes físicas (prédios escolares) & Ciberespaço \\
\hline Frequência obrigatória e horário rígido & Conveniência de local e hora \\
\hline Ensinar & Aprender a aprender \\
\hline Currículo mínimo, disciplinas obrigatórias e pré-requisitos & Conteúdos significativos e flexiveis \\
\hline Unidisciplinaridade & Inter, multi e transdisciplinares \\
\hline Pedagogia & Andragogia \\
\hline Transmissão do conhecimento & Aprendizagem coletiva \\
\hline Educação formal & Educação não formal \\
\hline Formação com duração prefixada & Formação ao longo da vida \\
\hline Educaçảo a distância & Aprendizagem aberta e flexível \\
\hline Economia de bens e serviços & Economia do conhecimento \\
\hline Professor & Orientador de aprendizagem \\
\hline Avaliação quantitativa & Avaliação qualitativa \\
\hline Diploma/certificado & Satisfaçáo de aprender \\
\hline
\end{tabular}

Figura 2.4 - Combinação entre os novos paradigmas e as TICs (Fonte: FORMIGA, 2009, p.43. Adaptado de MEISTER, 1999)

Na Educação a Distância, não basta incorporar a tecnologia em sua atuação. Ela exige que o professor tenha uma responsabilidade maior perante os cro- 
nogramas e pleno domínio do conteúdo, porque não existe a possibilidade de improvisar (BENTES, 2009).

Saraiva (1996) lembra que a EAD só se realiza quando há uma verdadeira comunicação bilateral nitidamente educativa. Ela precisa necessariamente ultrapassar a simples disponibilização de material instrucional. A EAD exige atendimento pedagógico que promova a relação professor-aluno através de estratégias institucionais. A necessidade do uso de cada vez mais recursos acaba exigindo mais dos desenhistas instrucionais, tutores e conteudistas. Para Nunes (2009), a intensidade da utilização de tecnologias torna o ensino mais complexo. Assim, o papel do docente na EAD superior se transforma, pois passa a criar conteúdos que serão entregues em diferentes mídias (livros, vídeo e podcasts, entre outros). Isso exige processos que precisam ser pensados e adaptados. Enquanto isso, a tutoria passa a ser a distância, individualizada e "mediatizada através de diversos meios acessíveis" (NUNES, 2009).

A distância física entre alunos e professores da EAD, somada à comunicação através do uso de mídias, são um desafio para as IES. Exigem investimentos não só tem tecnologia para mediação, como também representam uma mudança na cultura de professores e alunos que têm como parâmetro a educação presencial (MUGNOL, 2009). Búrigo et al. (2016) reforçam que as ações pedagógicas ocupam lugar central no processo de gestão da educação a distância porque atendem as necessidades de ensino e de aprendizagem. O processo pedagógico, assim, é quem escolhe a definição dos meios, da produção dos materiais e do sistema de comunicação, integrando as equipes no objetivo de fomentar o processo de aprendizagem dos alunos.

Esse novo papel dos professores e do material didático na EAD, aliado às necessidades pedagógicas do uso das TICs, trouxeram uma nova demanda para as IES: a formação de equipes técnicas de apoio aos conteudistas, formadas por profissionais de várias especialidades.

\section{5 .}

\section{A multidisciplinaridade na produção de material didático para EAD}

Segundo Moore e Kearsley (2007), a EAD exige técnicas especiais de criação de curso e de instrução. Isso é feito através não só de tecnologias, mas de dis- 
posição organizacionais e administrativas especiais. Porém, Moran (2011) afirma que muitas IES banalizam a EAD; pensam que é fácil, barata e que pode ser funcional com recursos mínimos e pouca especialização dos funcionários. Para o autor, muitos cursos são previsíveis, simplificados, com poucas atividades estimulantes e em ambientes virtuais pobres. Essas IES contratam profissionais com pouca experiência, mal remunerados e, no caso dos tutores, sobrecarregados de atividades e alunos. Em muitas instituições superiores, as equipes de EAD sofrem, pois os currículos não estão integrados, os investimentos maiores estão no presencial e falta visão estratégica a muitos gestores.

A maioria das IES produz seu próprio material textual e audiovisual (Figura 2.5), sem a terceirização de nenhuma parte da produção. Assim, esses estabelecimentos dispõem de infraestrutura necessária e de profissionais capacitados (ABED, 2015, p.9). Essa informação reforça a importância da formação e do bom funcionamento de equipes para produção do material didático.

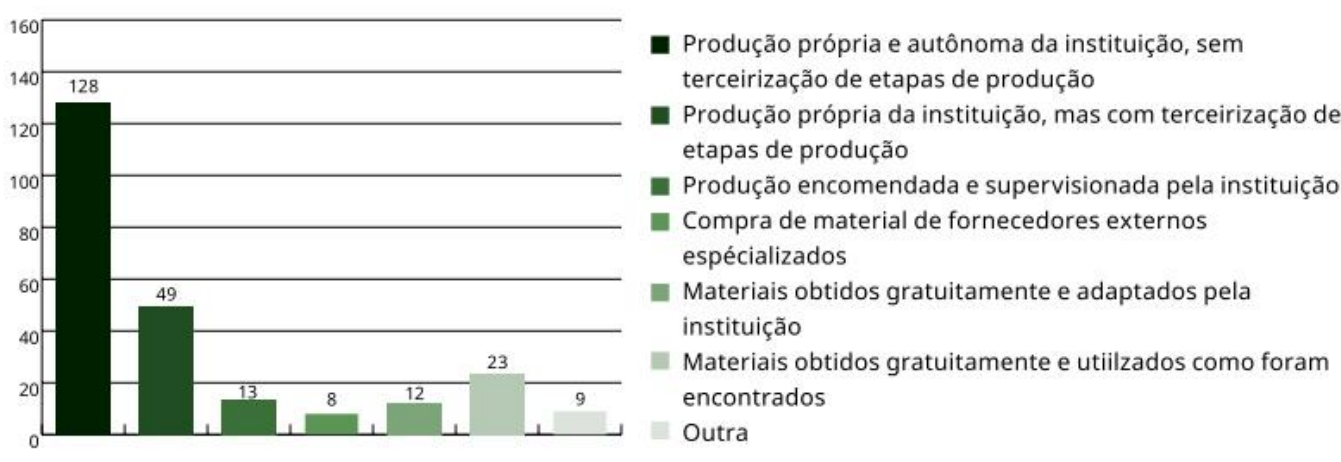

Figura 2.5 - Modo de produção dos materiais audiovisuais para EAD em 2014. (Fonte: ABED, 2015)

Como pode ser visto na Figura 2.6, ainda segundo o Censo da ABED (2015, p.47), $11 \%$ dos cursos a distância regulamentados ofereciam conteúdo exclusivamente físico aos alunos. Mas a maioria já oferece apenas materiais digitais on-line (63\%) ou materiais digitais combinados com físicos (23\%). Isso demonstra que as IES têm a necessidade de produção e combinação pedagógica de diferentes mídias. 


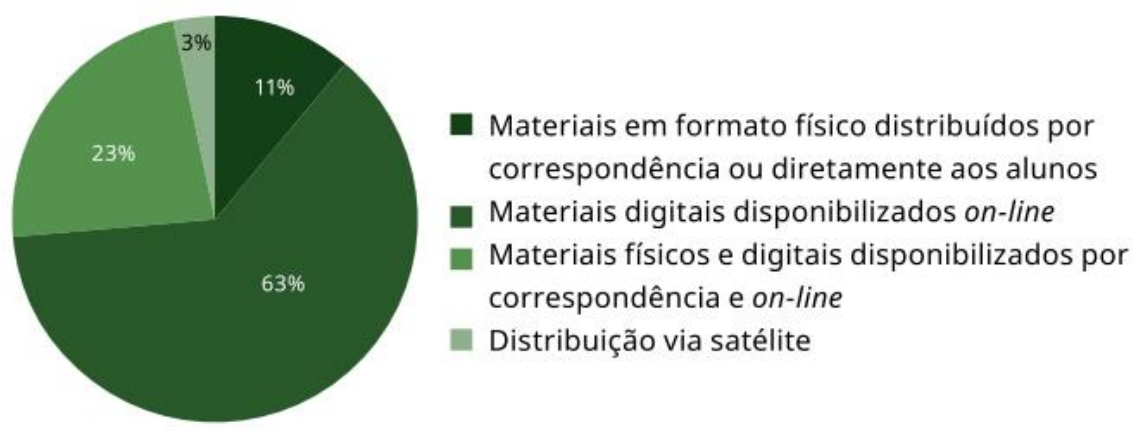

Figura 2.6 - Distribuição dos cursos regulamentados totalmente a distância oferecidos em 2014, de acordo com os materiais e a disponibilização (Fonte: ABED, 2015)

Nesse contexto, é plausível que um curso de graduação precise de professores conteudistas, desenhistas instrucionais, especialistas em filmagem e edição de vídeo e/ou áudio e profissionais de programação e/ou web design apenas para a construção de seu material didático.

Teixeira e Weschenfelder (2013, p.18) reforçam essa visão. Segundo eles, a apresentação final do trabalho envolverá várias pessoas: o professor que seleciona o conteúdo e preparar seus programas, o editor que dará legibilidade e o desenhista educacional que o organizará pedagogicamente. Além disso, o artista gráfico trabalhará sobre a aparência visual e arte final do texto.

Para Moreira (2009, p.372), num projeto EAD de pequena escala, profissionais ainda conseguem acumular funções. Por outro lado, projetos mais amplos, envolvendo a produção de materiais didáticos e a gestão de diferentes mídias, demandam a composição de uma equipe mais numerosa e com papéis diferenciados.

A interdisciplinaridade da equipe, segundo Longo (2009), é fundamental:

A interdisciplinaridade no processo de reconstrução do conhecimento e seu capital humano, em um programa de EAD, são fatores fundamentais para o sucesso. Portanto, a equipe envolvida nesse processo deve ser constituída por uma grande diversidade de profissionais com formação acadêmica sólida: $\mathrm{Ph}$.Ds, doutores, mestres, especialistas, graduados e trainees - contando com gestores, advogados, pedagogos, lingüistas, artistas plásticos, analistas de sistemas, programadores, profissionais da área de marketing, de operações e de tecnologia (LONGO, 2009, p.219).

Formiga (2009) afirma que o trabalho na produção e construção de conteúdo EAD requer um perfil de inovação próprio:

Trabalhar com a EAD requer profissionais e atores sensíveis e dispostos à inovação, porque atuam em um setor de transitoriedade, no qual a única certeza é a permanente mudança, cujas influências chegam pelos diferentes idiomas dos países que produzem conhecimento exponencial para a área. O profissional de EAD muito 
se assemelha ao conceito schumpeteriano de empresário inovador. Não há espaço para conservadores ou acomodados, exigem-se atividades ousadas e celeridade nas decisões, que obrigatoriamente envolvem riscos nas opções com as quais se defronta. Estar sempre de cabeça aberta às novidades e ser flexível para mudar a qualquer momento. Não é um território para dogmas ou verdades absolutas (FORMIGA, 2009, p.39).

Para Moreira (2009, p. 370 e 371), a conexão, na EAD, não é só dos computadores formando redes, mas entre pessoas. Isso demanda estratégias pedagógicas diferenciadas e um processo eficaz de gestão de processos e de pessoas que considere as novas formas de aprender em uma sociedade conectada. Para a IES, uma gestão dos componentes "pode favorecer a aprendizagem colaborativa e permanente da equipe, retroalimentando os processos de aprendizagem da própria instituição e a recontextualização de seus conceitos e práticas”.

Mas a montagem e o bom funcionamento de uma equipe multidisciplinar não é simples. Citando Brown (2010):

(...) é necessário paciência para alocar a um projeto pessoas com diversas formações e vindas de uma multidisciplinaridade de áreas. Isso requer a identificação de pessoas confiantes o suficiente em suas especialidades para se dispor a ir além dela (BROWN, 2010, p.26).

A composição e funcionamento da equipe deve levar em conta o perfil dos alunos e professores, as características do processo de ensino-aprendizagem e as mídias utilizadas. Além disso, devem ser consideradas as instituições, as políticas, a comunidade e a formação dos integrantes envolvidos (MOREIRA, 2009, p.377). Além das demandas técnicas e pedagógicas, os produtores de material didático também levam em conta um cenário cheio de especificidades. A EAD possui obstáculos e particularidades, como a alta taxa de evasão e o perfil diferenciado dos seus alunos. Esses temas serão abordados abaixo.

\section{6.}

\section{Evasão e obstáculos na EAD}

Segundo Nunes (2009, p.2), a Educação a Distância é voltada especialmente (mas não de forma exclusiva) para adultos que já estão no mercado de trabalho. Eles teriam tempo suficiente para estudar e completar sua formação ou fazer um novo curso. Segundo o autor, a clientela tende a ser não convencional, incluindo trabalhadores, deficientes físicos, populações em área de povoamento disperso ou 
simplesmente pessoas que residem longe das IES. O Censo da Educação Superior de 2013 (BRASIL, 2015, p.43) confirma a idade mais elevada dos estudantes na graduação a distância do que na presencial, bem como uma maior amplitude da distribuição das idades atendidas nessa modalidade:

(...) em média, o vínculo discente na condição de matrícula em um curso de graduação presencial tem 25,8 anos e, no curso a distância, 32,9 anos. Os ingressos na graduação presencial têm 24,6 anos em média, e, no curso a distância, 31,3 anos. Importa destacar que, nos cursos a distância (...) a idade mais frequente dos ingressos na modalidade a distância diminuiu de 30 para 28 anos. Finalmente, os concluintes na graduação presencial possuem, em média, 28,1 anos, e, na graduação a distância, 35,7 anos (BRASIL, 2015, p.42).

Essa característica faz com que o curso de EAD tenha um perfil diferente do presencial. Ele deverá considerar as características do seu público e a relação dessas pessoas com tempo, disponibilidade, cansaço cognitivo, etc.

Outra questão de suma importância na EAD é a evasão de alunos. Este, inclusive, é o obstáculo mais reportado pelas organizações que oferecem a modalidade. Longo (2009, p.219) lembra que a evasão é um problema existente também nos cursos presenciais, mas que na EAD, pelas características do público, costuma ser maior. A falta de vínculos afetivos com a turma e as dificuldades geradas pela mediação tecnológica seriam outros fatores determinantes, de acordo com o autor.

Segundo o Censo 2014 da ABED, os motivos mais reportados pelos alunos de cursos regulamentados semipresenciais para a evasão são a falta de tempo para estudar e a falta de adaptação à metodologia (ABED, 2015, p.77). Causa espanto que a maioria das instituições pesquisadas, no entanto, não possuía ou não forneceu os motivos para evasão de seus alunos (Figura 2.7).

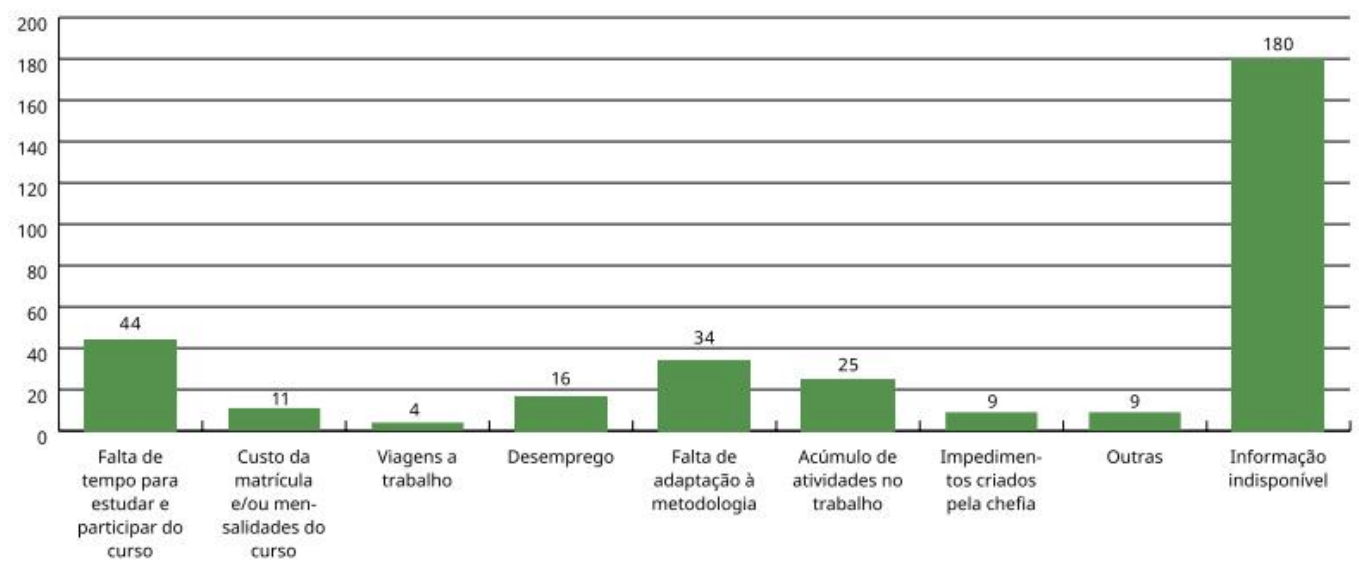

Figura 2.7 - Causas mais citadas para a evasão em cursos regulamentados semipresenciais em 2014 (Fonte: ABED, 2015) 
Se a evasão e a resistência dos educandos à EAD são obstáculos muito citados no Censo de 2014 (ABED, 2015, p.144) como utilizar o material e as ferramentas de comunicação como o AVA para diminuir esses problemas?

Se, ainda segundo a $\mathrm{ABED}$, a resistência dos educadores à EAD é um obstáculo maior que a dos educandos (Figura 2.8), como as IES podem dialogar com essas pessoas e diminuir essa aversão? Os profissionais estão sendo ouvidos? Participam das decisões e da construção educacional?

\begin{tabular}{|l|l|l|}
\hline Opções & Respostas & (\%) \\
\hline Resistência dos educadores à modalidade EAD & 80 & 33 \\
\hline Resistência dos educandos à modalidade EAD & 52 & 22 \\
\hline Custos de produção dos cursos & 77 & 32 \\
\hline Obtenção de lucros com os cursos & 34 & 14 \\
\hline Suporte em tecnologia da informação (TI) para docentes & 41 & 17 \\
\hline Suporte pedagógico e de TI para estudantes & 38 \\
\hline Acordos sindicais que definem cargas horárias de trabalho docente & 16 \\
\hline Desafios organizacionais de uma instituição presencial que passa a oferecer EAD & 60 \\
\hline Evasão de educandos & 116 \\
\hline Avaliação dos cursos & 14 & 33 \\
\hline Demanda de educandos interessados nos cursos & 48 \\
\hline Integração das novas tecnologias aos cursos & 6 \\
\hline Adequaçăo dos cursos para educandos com necessidades educacionais especiais para & 14 \\
\hline atender à legislação vigente & 39 & 17 \\
\hline Atender aos parâmetros de qualidades estabelecidos pelos órgãos de governo & 41 \\
\hline Outro(s) & 15 & 19 \\
\hline
\end{tabular}

Figura 2.8 - Obstáculos enfrentados pelas instituições formadoras na oferta de cursos EAD em 2014 (Fonte: ABED, 2015)

Assim, este capítulo buscou contextualizar a EAD no Brasil, relacionando suas particularidades e desafios com as novas tecnologias e as questões políticas, educacionais e sociais. Buscou mostrar um cenário pressionado por mudanças rápidas e profundas. Mudanças que demandaram a formação de equipes especializadas e multidisciplinares de trabalho. Mudanças que trouxeram novas necessidades organizacionais para as IES. Diante do quadro aqui exposto, viu-se que a produção de material didático para a graduação em EAD é uma atividade interdisciplinar complexa, com especificidades técnicas, socioculturais e pedagógicas. Também foi mostrado que, neste novo cenário, a produção de mídias e ferramentas são ainda mais fundamentais na comunicação e transmissão de conhecimento entre professores e alunos. Desta forma, a escolha e gestão dos profissionais responsáveis pelo material didático é fundamental para a EAD. 
O diálogo que o material precisa ter com o aluno talvez comece no diálogo que os profissionais da equipe multidisciplinar devem ter com as IES e entre si. As organizações dialogam com seus profissionais? Os profissionais estão dispostos a ouvir? Brown (2010, p.114), ao analisar a relação entre o Design Thinking e a exigência cada vez maior de se projetar experiências e não só produtos, tem uma frase que pode ajudar a responder algumas dessas questões: "Uma experiência excepcional começa com seu próprio pessoal".

No próximo capítulo, esta dissertação começa a abordar esses questionamentos, através do estudo de diferentes formas tradicionais de gestão de pessoas e de organizações. O que o campo da Administração pode trazer para avaliar o contexto multidisciplinar da EAD? É o que será apresentado a seguir. 


\section{3 \\ A relação entre o trabalho, as organizações e as pessoas}

No capítulo anterior, foram abordadas questões essencialmente externas ao trabalho multidisciplinar em EAD (legislação, crescimento das matrículas, tecnologia, entre outras). Agora, parte-se para questões de âmbito interno, como a relação das organizações com seus funcionários. Como ela é construída? Primeiramente, o capítulo foca nos sistemas de produção: como mudaram ao longo dos anos e como chegamos aos modelos atuais. Posteriormente, são analisadas algumas ferramentas e práticas organizacionais utilizadas pelas empresas e o seu impacto sobre os trabalhadores e sobre o produto final. Por fim, fala-se especificamente sobre a montagem de equipes multidisciplinares de EAD e quais características devem ser observadas neste processo.

\section{1. \\ O trabalho e os diferentes sistemas de produção}

As mudanças na sociedade, o desenvolvimento tecnológico e a evolução dos métodos produtivos criaram diferentes sistemas de trabalho, além de contextualizar os conceitos de gestão e formação de equipes que encontramos hoje.

Para um melhor entendimento desse cenário, é importante fazer uma reconstituição histórica do trabalho na produção em massa. Assim, ficam mais claros os diferentes momentos e modelos que a produção industrial capitalista adotou, e como eles são replicados até hoje, mesmo fora das fábricas.

O trabalho é uma atividade central para a sociedade. É essencial para a identidade individual e coletiva. É reveladora sobre a ordem social e sobre as mudanças pelas quais essa ordem passa. Também ajuda a revelar os tipos de problemas e questões que pessoas e governos devem abordar (KALLEBERG, 2009).

Muitas transformações na organização social e nas condições de vida e trabalho surgiram através de eventos como a Revolução Industrial e a saída dos trabalhadores do campo. Com o avanço da técnica e as transformações das relações 
sociais, ocorreram processos acelerados de industrialização e urbanização (LEÃO, 2012, p.294).

A necessidade de produção e sistematização dos processos trouxe a busca por gestão e organização do trabalho. Com isso, há uma transformação no paradigma da vida humana. Wood Jr. (1992, p.7) lembra que, com a troca da produção manual pela de massa, o humanismo dá lugar ao racionalismo. Constrói-se o mundo de acordo com princípios mecânicos: rigidez, predefinição, repetição e controle. Todo o sistema de valores e crenças foi afetado.

O reflexo desse sistema na vida humana se torna um objeto de estudo de vários campos do conhecimento. Pode-se citar, entre outras, a Sociologia, a Psicologia e a Administração (NAGUEL; DENCK, 2007, p.17).

Em meados do século XIX e nas primeiras décadas do século XX, já existiam práticas, investigações e experimentos no que tange aos problemas humanos no contexto industrial, em vários setores, como demonstra o nascimento da medicina do trabalho, bem como a obra de Max Weber (...) e as análises da psiquiatria de Emil Kraepelin, também na Alemanha, que, em 1902 já trabalhava com a noção mecânica da doença mental e com noções de pausas ótimas no trabalho e curva do trabalho (LEÃO, 2012, p.294).

Na Sociologia, segundo Kalleberg (2009, p.2), o trabalho é um tema central, que vem desde autores clássicos como Durkheim (divisão de trabalho), Marx (trabalho e alienação), e Weber (burocracia e fechamento social).

Nos estudos da Administração, Moraes Neto (1986) relaciona a obra de Marx ( $O$ Capital), como a base teórica do estudo do trabalho no contexto capitalista:

(...) a leitura de outros autores sobre processo de trabalho permite verificar que é bastante difundida a opinião de que o processo de trabalho capitalista no nosso século vai sendo, cada vez mais, um aprofundamento das coisas que Marx tinha colocado (MORAES NETO, 1986, p.31).

Coriat (1976, p.107) reafirma que as características apontadas por Marx do trabalho no capitalismo (parcelamento de tarefas, incorporação do saber técnico no maquinismo, caráter despótico da direção) foram aprofundadas posteriormente por Frederick Taylor, num sistema de produção que ficou conhecido por Taylorismo. São sistemas como o Taylorismo que serão abordados a seguir, para contextualizar os modelos produtivos surgidos através dos anos. Além disso, será 
mostrado como os sistemas deram origem aos conceitos de trabalho utilizados atualmente.

\title{
3.1.1.
}

\section{O sistema taylorista/fordista}

Segundo Moraes Neto (1986), o Taylorismo buscou controlar todos os passos, movimentos e o tempo do trabalhador. Ou seja, controlar o "trabalho vivo", transformando o homem em máquina. Taylor e seus seguidores queriam implementar uma visão mais científica (e menos empírica) nos processos industriais. Para isso, investigavam a execução das tarefas, desenvolvendo o que veio a ser chamado de "estudo do tempo e movimento" (NAGUEL; DENK, 2007, p.17). Leão (2012) também lembra que o taylorismo buscava controle ao retirar do trabalhador - e passar para a gerência - qualquer decisão sobre o seu fazer.

\begin{abstract}
A preocupação de Taylor também era o desperdício. As normas, princípios e leis "científicas" da administração do trabalho taylorista visaram, sobretudo, a exploração do trabalho em seu limite máximo, daí o estudo minucioso do tempo e movimentos, sendo um dos pontos fundamentais a separação entre os momentos de planejamento e execução do trabalho (BATISTA, 2008, p.5).
\end{abstract}

Algum tempo depois, na indústria automobilística de Henry Ford, a adoção da esteira de montagem dá origem a um novo modelo, o chamado Fordismo. Nele, houve a sistematização do trabalho mecanizado na fábrica. Com base nos métodos de Taylor e a padronização de poucos modelos, Ford produziu carros em série que puderam abastecer o consumo de massa (BATISTA, 2008). Antes da introdução da linha contínua, Ford já havia otimizado os processos ao ponto de reduzir o ciclo da tarefa de 514 minutos para apenas dois. Após implementar a produção linear, diminuiu este número à metade (WOOD JR., 1992).

O Fordismo utiliza elementos objetivos do processo ("trabalho morto") para objetivar a parte subjetiva do processo ("trabalho vivo"). O trabalhador é fixado no seu posto, enquanto o objeto de trabalho é transportado pelas esteiras, sem interferência do "trabalho vivo". Se possível, o trabalhador deve realizar apenas um mesmo movimento, continuamente, no seu processo de trabalho. Assim, o Fordismo, a linha de montagem, seria uma evolução do parcelamento de tarefas característico da manufatura (MORAES NETO, 1986, p.32 e 33). 


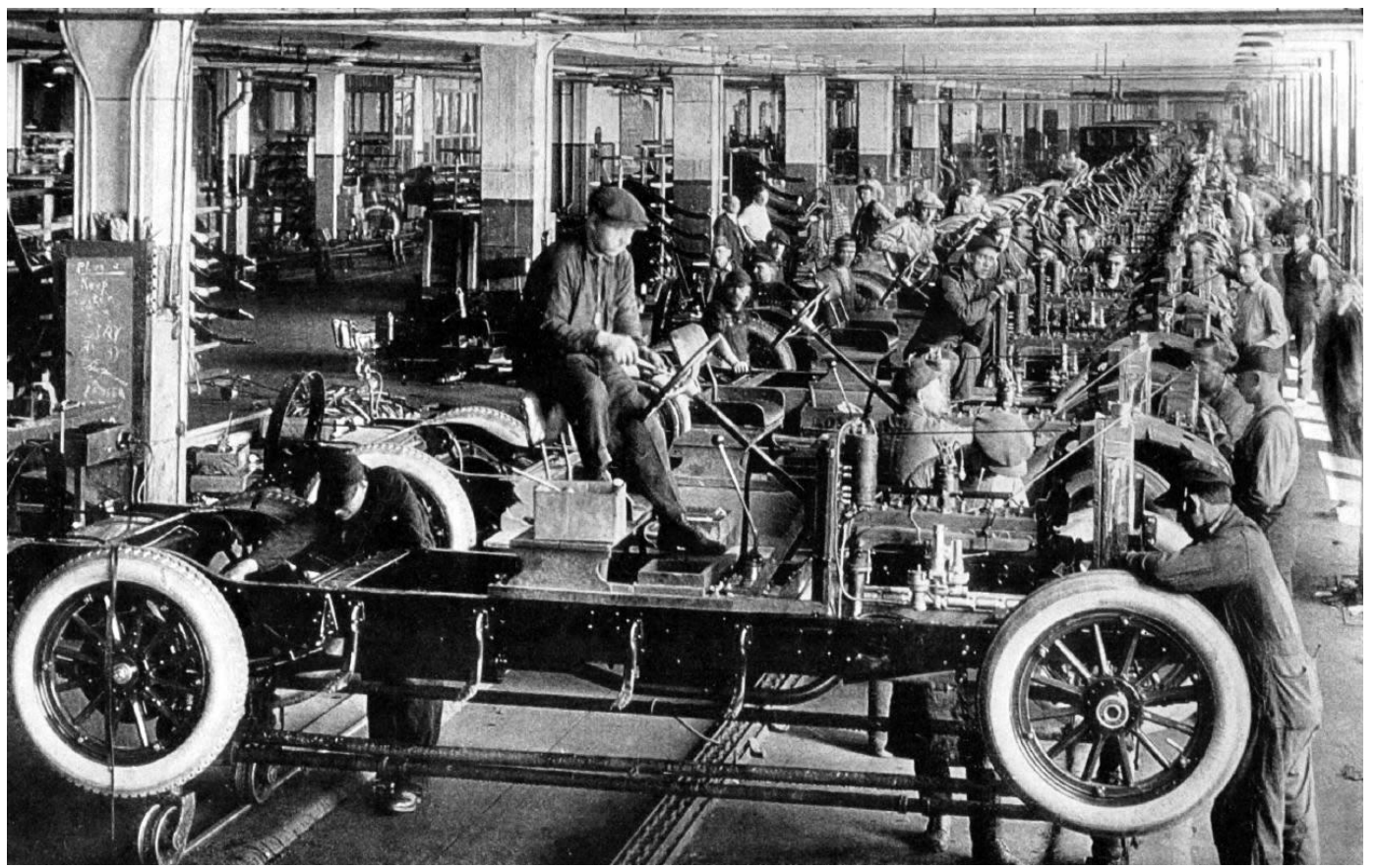

Figura 3.1 - Linha de montagem fordista

A intensa mecanização e a repetição quase robótica das tarefas no trabalho eram características completamente alheias ao comportamento humano. Por isso, essas modalidades de produção industrial logo apresentaram problemas: trabalho mal executado, absenteísmo, sabotagem e abandono de emprego. A limitação do modelo taylorista viria da destituição de conteúdo do trabalho realizado pelo funcionário, ao mesmo tempo em que sua ação manual sobre o objeto fabricado continuava necessária (MORAES NETO, 1986, p.33).

Navarro e Padilha (2007, p.17) confirmam o descontentamento dos operários. Foi registrada, segundo os autores, uma grande resistência dos trabalhadores ao Fordismo, causada pela forte mecanização. Batista (2008, p.7) diz que Gramsci, na década de 1930, e Friedmann, na de 1950, vislumbraram que o processo fordista/taylorista necessitaria ser reestruturado, e que surgiria um tipo superior de trabalhador, moldado pelo desenvolvimento do modo de produção.

Segundo Wood Jr. (1992, p.10), o modo taylorista/fordista começou a mostrar sinais de esgotamento em meados da década de 1950, com o aumento das reivindicações dos operários em questões de salários e jornadas de trabalho. Duas décadas depois, o modelo foi posto em cheque. Isso ocorreu, principalmente, pela crise do petróleo e a ascensão das empresas japonesas, em especial a Toyota (que propôs uma nova metodologia de produção em massa). Essas montadoras nipôni- 
cas inundaram o mercado com modelos mais baratos que consumiam menos combustível.

O desenvolvimento tecnológico e a internacionalização dos mercados produtor e consumidor forçaram as empresas à adaptação. A década de 1980 testemunha uma onda de reestruturações produtivas, num cenário de mais competição. Reduz-se os custos de produção, busca-se maior qualidade e produtividade. Investe-se em tecnologia e em arranjos organizacionais (NAVARRO; PADILHA, 2007, p.17).

A competitividade entre as empresas, a pressão por resultados e eficácia produtiva, a fim de garantir sobrevivência e destaque, levou-as a reduzir custos, efetuar empowerment (delegação do poder de decisão) e downsizing (enxugamento das estruturas organizacionais, reduzindo níveis hierárquicos) em sua estrutura. Objetivando crescente marketshare (participação no mercado), aponta para a tendência de equipes multidisciplinares, com formação generalista e contínua, além de jobrotation (revezamento de funções) intradepartamental para flexibilizar comportamentos (NAGUEL; DENCK, 2007, p.15 e 16).

Nesse sentido, os métodos da Toyota, juntamente com o cenário de globalização e as inovações tecnológicas, modificam os paradigmas de produção através de estratégias corporativas inovadoras. Um dos focos dessas mudanças foi o papel dos operários nas fábricas. É este recorte que será analisado a seguir.

\subsection{2. \\ O sistema toyotista (flexível)}

O modelo Toyotista (também conhecido como Produção Flexível) foi uma adaptação do fordismo para o âmbito do empregado japonês. Aqui, o funcionário necessita de mais treinamento e motivação. Os trabalhadores eram agrupados em torno de um líder e tinham responsabilidade sobre uma série de tarefas. Com o tempo, passaram a ser marcados encontros para discussão de melhorias nos processos de produção. O funcionário também ganhava autonomia de parar, ele mesmo, a linha de produção assim que detectasse um problema, desburocratizando os processos (WOOD JR., 1992, p.13).

No toyotismo, o saber tácito do trabalhador é utilizado no sistema de padronização das operações. Adota-se o princípio de combinar trabalho em equipe e habilidade individual. As aptidões pessoais são desenvolvidas até a plenitude. Busca-se iniciativa e comprometimento dos trabalhadores, juntamente com o en- 
volvimento da gerência. A lógica da Toyota impôs um sistema de gestão total, advindo da padronização de tarefas, que somava o trabalho repetitivo e o multifuncional (BATISTA, 2008, p.10). Ou seja, nesse modelo abandona-se o empregado quase "robótico", fixado exclusivamente em sua tarefa e alienado das outras fases de produção. Adota-se um padrão mais colaborativo e participativo, e o agrupamento de funcionários em equipes menores foi um embrião do que hoje se utiliza em equipes multidisciplinares e em sistemas de gestão de projetos, especialmente no caso das metodologias ágeis.

Esse modelo teve grande impacto sobre a produtividade, qualidade e velocidade de resposta às demandas do mercado. O sistema flexível da Toyota soube capitalizar as necessidades do consumidor e se adaptar às mudanças tecnológicas (WOOD JR., 1992, p.14).

Boltanski e Chiapello (2009, p.111 e 112) lembram que esses dispositivos foram, também, uma forma de passar o controle, antes exercido por executivos de alta remuneração, para os próprios assalariados. Assim, os trabalhadores passariam a se autocontrolar. O Taylorismo pressupõe a separação entre concepção, controle e execução. No modelo da Toyota, os operários, agora chamados de operadores, aos poucos foram encarregados pelo controle de qualidade e até pela manutenção. Era preciso formar os operadores, para que pudessem garantir reparos de emergência. O nível de qualificação, assim, é comparativamente mais elevado do que nos modelos anteriores.

O formato toyotista também tem seus problemas. Navarro e Padilha (2007, p.19) sublinham que a flexibilização produtiva teve grande exigência sobre os trabalhadores. Demandas de agilidade, adaptação a mudanças de curto prazo, adoção de riscos e independência de leis e procedimentos formais. A empresa enxuta trouxe sobrecarga de trabalho para aqueles que sobreviveram ao corte de postos funcionais. Houve um aumento de tarefas e responsabilidades que não foi acompanhado pelas políticas salariais. Ou seja, era preciso trabalhar e estudar mais para receber o mesmo pagamento.

Apesar de terem surgido em sequência, nenhum desses modelos acabou com o outro. Os modelos clássicos, mecânicos, que alienam o trabalhador de sua tarefa, não acabaram. Todos são adotados até hoje ao redor do mundo. Os diferentes sistemas de trabalho são utilizados, em maior ou menor escala, dependendo do setor produtivo, tipo de organização e área de atuação. 
Mesmo originados no âmbito industrial, os sistemas de produção tiveram a sua lógica aplicada nas organizações em geral. Para Batista $(2008$, p.8), as características das diferentes formas de gerenciamento de produção foram ampliadas "para fora" da esfera econômica. Partindo de Taylor, Ford e sofisticadas pelo Toyotismo, elas abrangem as relações pessoais nos planos político, ideológico e cultural. A relação trabalho-organização é compreendida além da esfera industrial, envolvendo também variados tipos de ambientes (LEÃO, 2012, p.296).

Após abordar a questão das pessoas e o trabalho, esta pesquisa se volta para o terreno onde esta relação ocorre: as organizações. Como suas decisões e visão influenciam o trabalhador? Como abordam a gestão de pessoas? Como constroem sua cultura de trabalho e funcionamento?

\section{2. As organizações e suas relações com os funcionários}

Assim como o estudo do trabalho, a gestão das organizações se tornou um campo interdisciplinar, com foco acentuado em muitas áreas além da Administração clássica: Psicologia, Estatística, Sociologia e até a Biologia (DIAS, 2002, p.8 e 9). Neste subcapítulo, serão expostos alguns conceitos sobre esses estudos no que se refere às pessoas nas organizações. Como o capital humano é tratado e visto no âmbito organizacional e qual a dimensão da sua importância.

De forma geral, o Modelo de Gestão é a ferramenta utilizada pela organização para esquematizar suas atividades. Para isso, constroem-se procedimentos, normas, ferramentas e regras. Essas construções, bem como os gestores, devem se referenciar à missão, visão, crenças e valores da empresa. Enfim, a prática deve se relacionar ao discurso (MEDEIROS et al., 2011). Não adianta a adoção de diretrizes, se as mesmas não forem seguidas no cotidiano da organização.

Santos et al. (2014, p. 109) citam a perspectiva de Hammer (1996), na qual a organização é configurada por meio de quatro elementos principais: processos de negócio; atividades e estrutura organizacional; gestão e sistemas de mensuração; valores e crenças de seus funcionários. Esses elementos são interdependentes e se influenciam mutuamente.

Esta pesquisa, após revisão bibliográfica, escolheu destacar três desses elementos: a cultura organizacional, a gestão de pessoas e a estrutura organizacional. 
Esta opção foi tomada por entender que esses fatores são os mais próximos da relação empresa-funcionário; e que os processos de negócios pertencem a um campo mais administrativo, que foge do recorte desta dissertação.

\subsection{1. \\ A cultura organizacional}

Uma das ferramentas de construção da relação entre as organizações e seus funcionários, através da definição de missão, visão e valores, é a chamada cultura organizacional:

Cultura refere-se ao "padrão de desenvolvimento refletido nos sistemas sociais de conhecimento, ideologia, valores, leis e rituais quotidianos" (MORGAN, 2002, p. 115). Ao especificar a visão geral de cultura no âmbito das organizações, Martin (1992) afirma ser a cultura organizacional constituída por diversos elementos, os quais incluem normas informais, histórias que pessoas contam sobre o que está acontecendo, procedimentos e normas formais da organização, seus códigos de comportamento informal, rituais, tarefas, sistemas de pagamento e jargões entendidos apenas por aqueles inseridos na organização, dentre outros. Esse conjunto de elementos representa algumas das muitas manifestações da cultura organizacional e constitui a cultura os padrões ou configurações das interpretações, bem como as formas como elas são cumpridas (SANTOS et al., 2014, p.111).

Segundo Barreto et al., (2013, p.35), O estudo da cultura organizacional é baseado na Psicologia, Antropologia, Sociologia e nas Ciências Políticas. Além disso, entre as muitas visões sobre a influência desses paradigmas, citam Allaire e Firsirotu (1984) ao defender que elas podem ser agrupadas em dois blocos. Um, entende a cultura organizacional de forma sociocultural, influenciada pelos níveis nacionais, regionais e sociais. Ela determina a identidade de um grupo assim como a personalidade determina a identidade de um indivíduo. Outro bloco identifica a cultura organizacional como um sistema de ideias, onde ela não só representa o comportamento, mas também um conjunto de mecanismos de controle do mesmo.

Compartilhando a visão de Smircich (1983), Barreto et al. (2013, p.35 e 36) também consideram a cultura organizacional uma variável que se utiliza enquanto ferramenta. Ela tanto dita o rumo das empresas quanto aplica estratégias. Assim, a organização é um resultado coletivo de valores, crenças e de um compromisso assumido. 
Santos et al. (2014, p.112) reforçam a necessidade de os gestores tornarem clara a visão da organização como "um conjunto de processos interligados que trabalham de maneira alinhada aos objetivos estratégicos". Os objetivos de cada equipe e departamento, mesmo particulares, devem ser harmoniosos com os objetivos gerais da empresa.

Barreto et al. (2013, p.36) citam o modelo de valores competitivos de Quinn e Rorbaugh (1981) como uma ferramenta de análise da cultura organizacional aplicada por Cameron e Quinn (2006). Segundo os autores, o modelo pressupõe que as organizações podem se caracterizar pelos seus traços comuns. Assim, pode-se "definir os tipos de cultura, interpretar seus atributos e estudar a cultura em termos comparativos". Os valores organizacionais preponderantes significariam a adoção de um estilo cultural, e este define o comportamento competitivo da organização em vários níveis: desenvolvimento humano e corporativo, estrutura organizacional (controle, estabilidade, flexibilidade), planejamento, resultados e produtividade. Essa tipologia propõe quatro modelos de cultura (Tabela 3.1 e Figura $3.2)$ :

\begin{tabular}{|c|c|}
\hline Tipo de cultura & Características \\
\hline Cultura clã & $\begin{array}{l}\text { - Desenvolvimento das pessoas e participação nas decisões; } \\
\text { - A autoridade flui quando emana de membros comprometidos com o sistema há muito } \\
\text { tempo; } \\
\text { - Os líderes tendem a uma postura participativa, oferecendo suporte e facilitando a } \\
\text { interação, a confiança e a lealdade. }\end{array}$ \\
\hline $\begin{array}{c}\text { Cultura } \\
\text { inovativa }\end{array}$ & $\begin{array}{l}\text {-Pressupostos de mudança e flexibilidade; } \\
\text { - Motivação calcada em crescimento, estímulo, diversificação e criatividade; } \\
\text { - Líderes tendem a ser empreendedores e idealistas; apreciam riscos e previsão do } \\
\text { futuro; } \\
\text { - Se preocupam em obter recursos, suporte e imagem externa; } \\
\text { - Ênfase na aquisição de conhecimentos em produtos e/ou serviços. }\end{array}$ \\
\hline $\begin{array}{l}\text { Cultura de } \\
\text { mercado }\end{array}$ & $\begin{array}{l}\text { - Orientado para tendências de mercado e bases seguras de clientes; } \\
\text { - Motivação baseada em competição e consecução de resultados; } \\
\text { - Líderes tendem a ser diretivos, realizadores, competidores, orientados para o objetivo } \\
\text { e encorajam a produtividade. São severos e exigentes. } \\
\text { - O elemento que fundamenta a organização é a ênfase no vencedor. }\end{array}$ \\
\hline $\begin{array}{c}\text { Cultura } \\
\text { hierárquica }\end{array}$ & $\begin{array}{l}\text { - Pressupostos de estabilidade; } \\
\text { - Reflete os valores e normas associados à burocracia; } \\
\text { - Empregados aceitam bem a autoridade que emana de papéis formalmente estabeleci- } \\
\text { dos, de regras e regulamentos impostos; } \\
\text { - Motivação inclui segurança e ordem; } \\
\text { - Os líderes tendem a ser conservadores em relação aos problemas de natureza técnica. }\end{array}$ \\
\hline
\end{tabular}

Tabela 3.1 - Características dos tipos de cultura propostos por Cameron e Quinn (2006) (Fonte: Baseado em Barreto et al., 2013) 


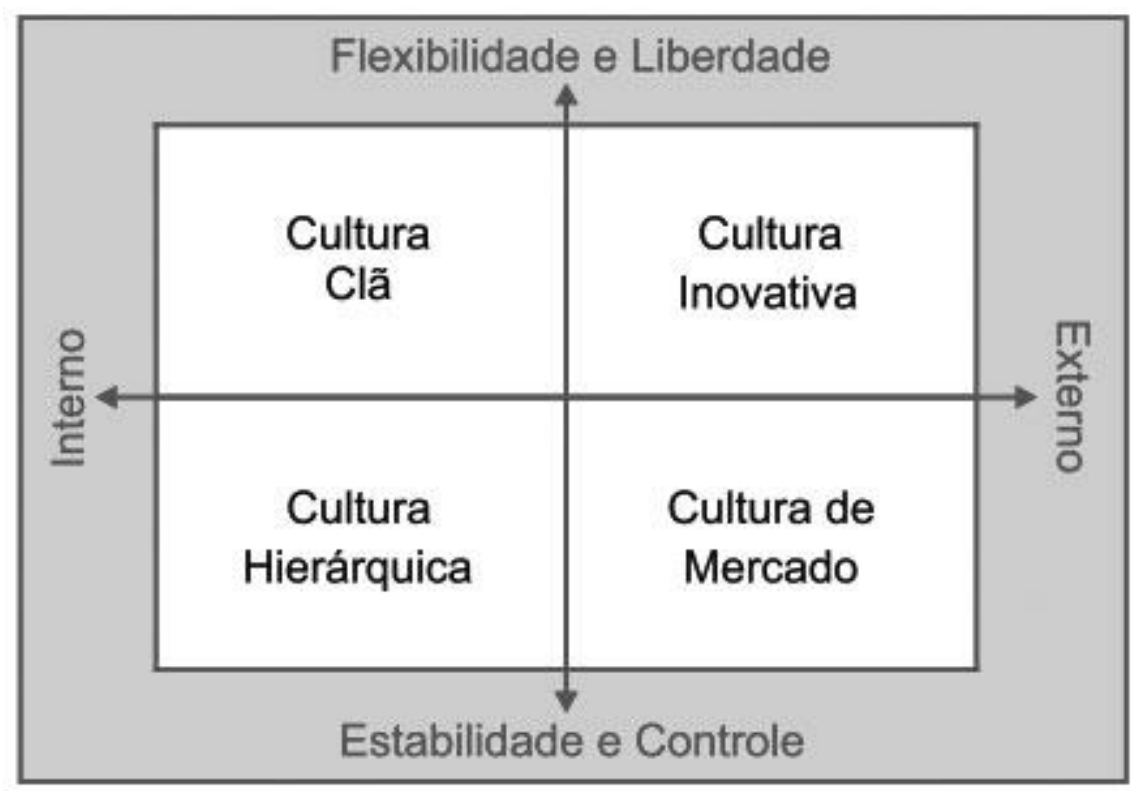

Figura 3.2 - Tipologia cultural proposta por Cameron e Quinn, 2006 (Fonte: Barreto et al., 2013)

Um elemento fundamental na construção dessa cultura é a liderança exercida dentro das empresas. Bastos (2009, p.101), citando Davel e Vasconcelos (2006), lembra que a ideia de tratar a empresa como uma família, e o patrão como uma figura paterna, pode causar problemas. Em muitas dessas organizações, pessoas são alçadas a cargos de liderança não por competência, mas por boa adaptação, docilidade à direção e fidelidade. A falta de preparo das lideranças atinge diretamente os funcionários, que sentem insatisfação, falta de cooperação e dificuldade de relacionamento interpessoal.

A escolha dos líderes é, por si só, um pilar de sustentação da organização. O perfil da liderança é correlato à montagem da cultura. São os líderes que escolhem e criam as ferramentas para o desenvolvimento e o reforço de normas e comportamentos internos. Diretrizes culturais surgem e mudam de acordo com o foco de sua atenção. Além disso, também são relevantes o modo como a liderança reage a crises, se comporta e constrói o capital humano da empresa (BARRETO et al., 2013, p.39 e 40).

A relação de poder entre indivíduos também é um tema estudado no âmbito organizacional e da psicologia do trabalho. A forma como líderes exercem seu poder sobre os funcionários é uma variável fundamental no funcionamento de uma empresa. Lana et al. (2016, p. 515), citam a visão de Spector (2006) e Fresch e Raven (1959), onde essa influência é baseada em cinco fatores calcados em ca- 
racterísticas individuais e organizacionais (Tabela 3.2). Os autores afirmam que as bases desse poder não são uma relação direta, vinda apenas do sujeito em posição de comando. O poder se configura da interação entre os atores. É o comportamento do subordinado que determina a influência do poder do comandante.

\begin{tabular}{|l|l|l|}
\hline \multicolumn{1}{|c|}{ Base } & \multicolumn{1}{|c|}{ Utilização } & \multicolumn{1}{c|}{ Características } \\
\hline Experiência & Fornecer informações & $\begin{array}{l}\text { Baseada no conhecimento e perícia do superior. Subordinado } \\
\text { seguiria as diretrizes de uma pessoa que ele acredita ter conhe- } \\
\text { cimento ou perícia especial sobre o assunto em questão. }\end{array}$ \\
\hline Referência & $\begin{array}{l}\text { Fazer com que os } \\
\text { subordinados gostem } \\
\text { de você }\end{array}$ & $\begin{array}{l}\text { Os subordinados gostam ou se identificam com o superior. } \\
\text { Pode ser desenvolvida por meio de relacionamentos pessoais } \\
\text { com outras pessoas ou ser aumentada elevando-se o status do } \\
\text { supervisor. }\end{array}$ \\
\hline Legitimidade & $\begin{array}{l}\text { Obter um alto cargo } \\
\text { ou escalão }\end{array}$ & $\begin{array}{l}\text { Inerente ao título do superior. Deriva da crença dos funcioná- } \\
\text { rios de que o supervisor tem o direito legítimo ou a autoridade } \\
\text { para estar no comando. Resultado dos valores do subordinado } \\
\text { a respeito dos direitos do supervisor. Se o subordinado se } \\
\text { recusa a reconhecer a autoridade, não haverá nenhum poder no } \\
\text { título. }\end{array}$ \\
\hline Recompensa & $\begin{array}{l}\text { Dar recompensas pela } \\
\text { conformidade }\end{array}$ & $\begin{array}{l}\text { Habilidade de recompensar subordinados com bônus, atribui- } \\
\text { ções desejadas, promoções ou aumentos de salário. }\end{array}$ \\
\hline Coerção & $\begin{array}{l}\text { Punir e não- } \\
\text { conformidade }\end{array}$ & $\begin{array}{l}\text { Habilidade de punir os subordinados com ações disciplinares, } \\
\text { multas, demissão ou reduções de salário. }\end{array}$ \\
\hline
\end{tabular}

Tabela 3.2 - As cinco bases da influência e poder interpessoais (Fonte: LANA et al., 2016, p.515. Baseado em SPECTOR, 2006, p.331)

O uso do poder é uma ferramenta que pode ser ou não benéfica. Se bem aplicada, melhora a organização como um todo. Pode criar um ambiente positivo entre indivíduos e ter efeito sobre a produção do trabalhador. Por outro lado, pessoas em posição de chefia podem usá-la para maltratar subordinados. Em casos mais leves, isso ocorre por características pessoais do superior, ou seja, isoladamente. Mas, onde é sistemática, se configura em sintoma de uma cultura calcada na punição como incentivo à produtividade (LANA et al., 2016).

\subsection{2.}

\section{A gestão de pessoas}

A gestão de pessoas é um dos grandes pilares da construção de uma organização. Chiavenato (1999) afirma que ela é situacional, pois depende da cultura, da estrutura organizacional, do ambiente, da atividade produtiva e da tecnologia adotada, entre outras variáveis.

Segundo Corrêa, Gonçalves e Santos (2016, p.82) a gestão de pessoas tem como função “desenvolver políticas, processos e práticas estrategicamente desenhadas para a realidade do seu contingente de recursos humanos". Ainda segundo 
os autores, essa área vem evoluindo ao romper com a visão tradicional, que concebia o ser humano como uma fonte de custos, e abordar o desenvolvimento do trabalhador como um parceiro estratégico. Chiavenato (1999, p.4 e 7) corrobora essa visão. Ele afirma que, para maximizar a mobilização dos funcionários, as organizações trocam o investimento direto nos clientes, produtos e serviços pelo investimento nas pessoas que os entendem e melhoram sua relação com as organizações. O corpo de funcionários é visto como um ativo, e sua gestão é um diferencial para manter ou conquistar vantagens competitivas no mercado. $\mathrm{O}$ autor também lembra que a organização pode escolher entre tratar as pessoas como recursos ou como parceiros. Como recursos, as pessoas precisarão ser administradas e ter suas atividades controladas. A elas é dado o papel de sujeito passivo na relação. Já como parceiros, as pessoas fornecem suas habilidades, capacidades e inteligência, construindo o capital intelectual da empresa.

\begin{tabular}{|l|l|}
\hline \multicolumn{1}{|c|}{ Pessoas vistas como recursos } & \multicolumn{1}{c|}{ Pessoas vistas como parceiros } \\
\hline - Empregados isolados nos cargos & - Colaboradores agrupados em equipes \\
- Horário rigidamente estabelecido & - Metas negociadas e compartilhadas \\
- Preocupação com normas e regras & - Preocupação com resultados \\
- Subordinação ao chefe & - Atendimento e satisfação do cliente \\
- Fidelidade à organização & - Vinculação à missão e à visão \\
- Dependência da chefia & - Interdependência entre colegas e equipes \\
- Alienação em relação à organização & - Participação e comprometimento \\
- Ênfase na especialização & - Ênfase na ética e na responsabilidade \\
- Executoras de tarefas & - Fornecedoras de atividade \\
- Ênfase nas destrezas manuais & - Ênfase no conhecimento \\
- Mão-de-obra & - Inteligência e talento \\
- Parte do patrimônio físico da organização & - Parte do patrimônio intelectual da organização \\
\hline
\end{tabular}

Tabela 3.3 - Diferenças entre os funcionários vistos como recursos e vistos como parceiros (Fonte: Chiavenato, 1999, p.7)

Wood Jr. (1992, p.9) sublinha que são as organizações que devem se mobilizar ao redor das pessoas. O inverso disso causa uma limitação da capacidade humana que prejudica a própria empresa. Para alcançar a eficiência, é preciso buscar a conciliação entre o que trabalhadores precisam e o que a empresa necessita (LEÃO, 2012). Uma maneira da empresa se mobilizar em torno das pessoas pode ser a descentralização das atividades de RH. Nesse cenário, a administração da área de recursos humanos deixa, aos poucos, suas funções burocráticas de lado e orienta os gestores a cuidarem das pessoas. Assim, os gerentes passam a ser os corresponsáveis, junto com o setor de RH, pelo pessoal. Os benefícios podem ser vistos na Figura 3.3: 


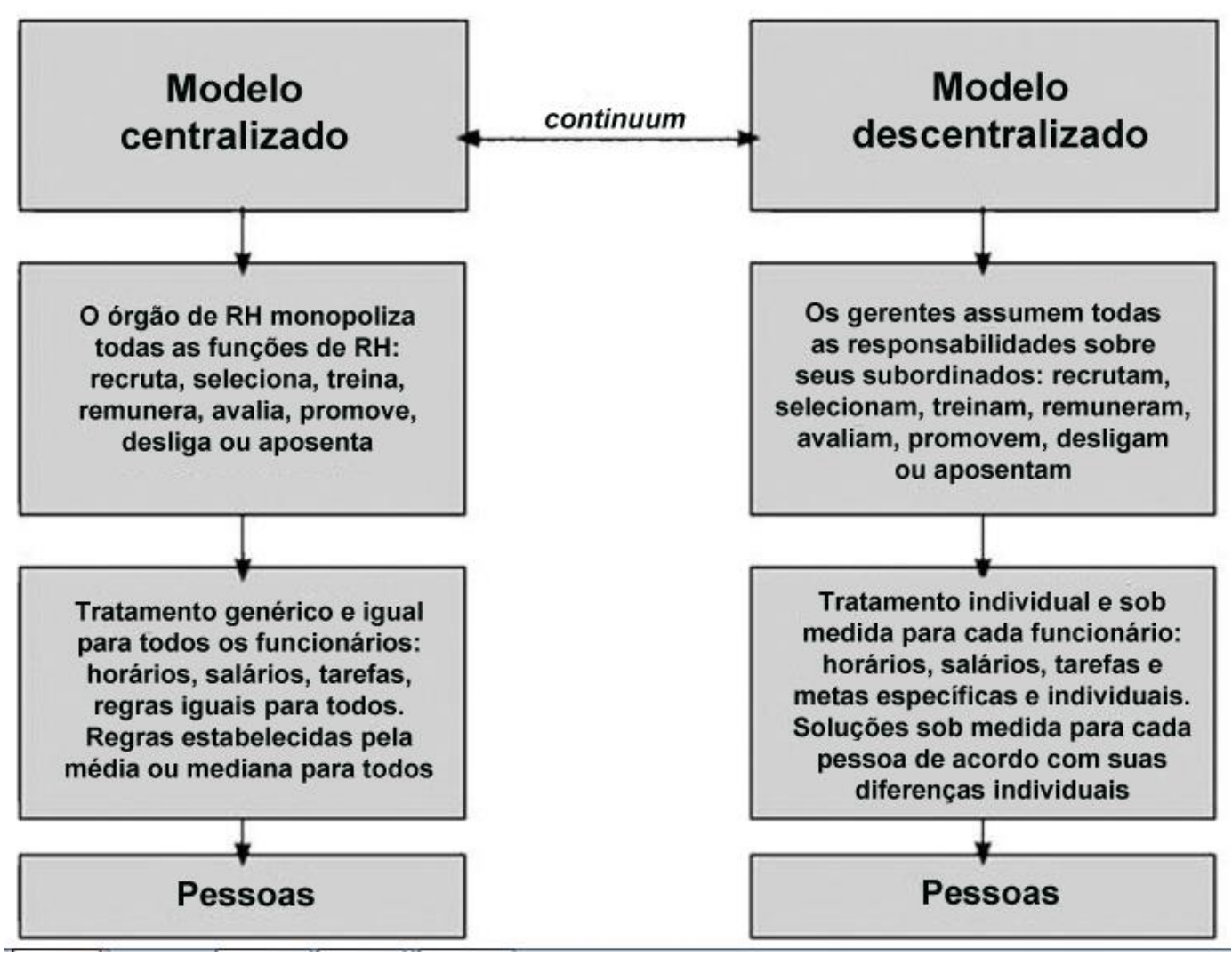

Figura 3.3 - Os modelos centralizado e descentralizado de gestão de pessoas (Fonte: Grupo Editorial Campus/Instituto Chiavenato. Baseado em Chiavenato, 1999, p.24)

Santos et al. (2014, p.111), citando Huselid (2005), lembram que práticas e políticas de gestão de pessoas podem afetar o desempenho do funcionário, seja atingindo as habilidades ou a motivação do indivíduo. Chiavenato (1999, p.9) destaca que pessoas podem "ampliar ou limitar as forças e fraquezas de uma organização, dependendo da maneira como elas são tratadas". Ainda segundo ele, para alcançar os objetivos é preciso que os gerentes tratem as pessoas como elementos básicos para a eficácia organizacional.

As empresas, em geral, percebem com facilidade a desmotivação do trabalhador, pois a chefia relaciona a falta de motivação ao desempenho. Porém, como afirma Bastos (2009, p.115), muitas vezes não há uma autocrítica: o que a organização está fazendo para acabar com o prazer no trabalho? É importante destacar que uma das atribuições da administração de recursos humanos nas empresas, na visão de Chiavenato (1999, p.9), é a manutenção da Qualidade de Vida no Trabalho. A QVT engloba a experiência do trabalho de forma geral: estilo de gerencia, liberdade e autonomia, ambiente de trabalho, segurança no emprego e tarefas significativas. 
Chiavenato (1999, p.14) também esquematizou os processos de gestão de pessoas num diagrama chamado Modelo de Diagnóstico de $\mathrm{RH}$, que explicita didaticamente todas as etapas, a importância e a estrutura desse setor na organização:

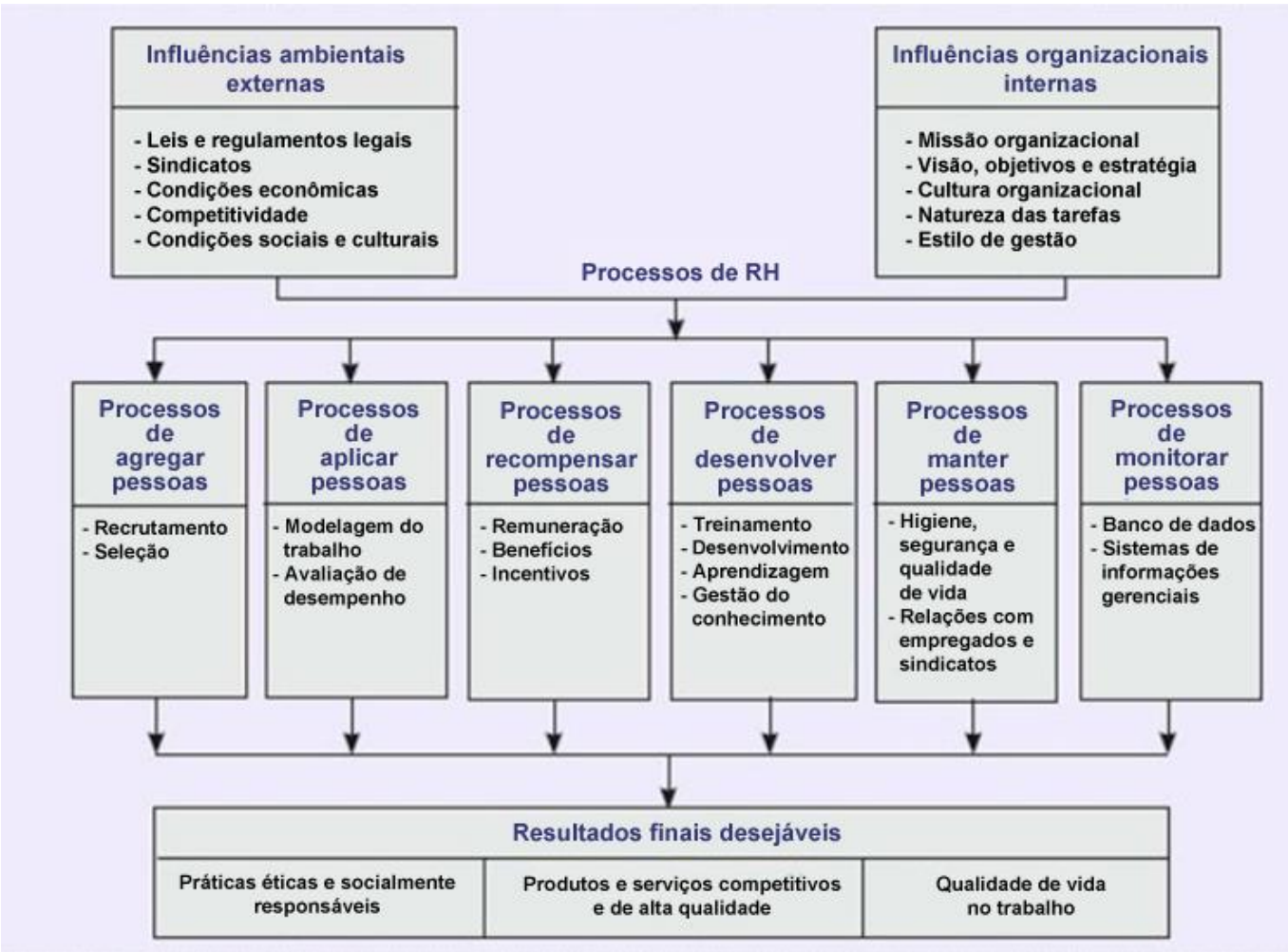

Figura 3.4 - Modelo de Diagnóstico de RH (Fonte: Grupo Editorial Campus/Instituto Chiavenato. Baseado em Chiavenato, 1999, p.14)

\subsection{3.}

\section{A estrutura organizacional}

Outra questão importante nesta equação é o desenho da estrutura da instituição, cujas características podem ajudar (ou não) a melhoria do trabalho do empregado. A estrutura organizacional é a forma como a empresa é montada para desenvolver suas atividades. Ela nunca pode ser considerada pronta ou perfeita, pois não pode ser inflexível. Deve ter capacidade de adaptação aos diferentes momentos vividos pela organização em sua existência (MEDEIROS et al., 2011).

Para Santos et al. (2014), a empresa pode ser vista como uma sequência de processos funcionais conectados, onde os altos funcionários escolhem as políticas e o direcionamento. Já o papel de gerir os métodos de trabalho é feito pelas equipes interfuncionais: 
A preocupação com a estrutura organizacional volta-se para a facilitação da integração dos fluxos de atividades entre as diferentes áreas, o que demanda e implementa mudanças nas políticas de recursos humanos, fazendo com que os funcionários passem a ter maior participação no resultado final (DeTORO; MCCABE, 1997; GONÇALVES, 2000b) (SANTOS et al., 2014, p113).

Nesse aspecto, as organizações se dividem em dois tipos, Mecânicas e Orgânicas:

\begin{tabular}{|l|l|l|}
\hline \multicolumn{1}{|c|}{ Tipo } & \multicolumn{1}{|c|}{ Características } & \multicolumn{1}{c|}{ Estruturas } \\
\hline $\begin{array}{l}\text { Organização } \\
\text { Mecânica }\end{array}$ & - Atividades divididas em tarefas & - Cargos estreitos em conteúdo; \\
& separadas por especialidades; & - Regras e procedimentos; \\
& - Centralização, hierarquia; & - Claras responsabilidades; \\
& - Regras, regulamentos, controles; & - Sistemas objetivos de recompensas; \\
& - Variabilidade humana vista como & - Critérios objetivos de seleção, informal e im- \\
& inconsistência; & pessoal; \\
& - Organização conservadora; & - Tarefas e metas conhecidas; \\
& & - Tarefas divisórias; \\
& & - Desempenho por medidas objetivas; \\
& & - Empregados responsivos; \\
\hline Organização & - Recompensas monetárias; \\
Orgânica & menos ordens; & - Autoridade aceita como legítima. \\
& - Comunicação ocorrendo em todos & - Responsabilidades ambíguas; \\
& os níveis da organização; & - Sistemas subjetivos de recompensas; \\
& - Variabilidade humana utilizada & - Sistemas subjetivos de seleção; \\
& para tomada de decisões; & - Tarefas e metas vagas; \\
& - Supervisão direta e quantidade de & - Tarefas divisíveis; \\
& regras menores; & - Desempenho por medidas subjetivas; \\
& - Trabalho em equipe = aprendizado & - Empregados motivados por necessidades com- \\
& contínuo; & plexas e autoridade desafiada. \\
& - Organização do tipo flexível. & \\
\hline
\end{tabular}

Tabela 3.4 - Tipos de organizações, suas características e estruturas (Fonte: baseado em MEDEIROS et al., 2011)

Segundo Wood Jr. (1992, p.15), as organizações não são totalmente racionais, pois seus integrantes têm acesso a redes limitadas de informações. Os planos, procedimentos e normas criadas tentam driblar essa limitação, simplificando as questões organizacionais. A visão mecânica o faz através de sistemas de decisão rígidos, enquanto a orgânica usa processos mais flexíveis.

Numa organização mecanicista, ou burocrática, a fragmentação do trabalho e da estrutura desencoraja a autonomia. Adicionalmente, os sistemas de avaliação, recompensa e punição representam um empecilho ao ciclo de melhoria. Certas ações podem, entretanto, levar ao desenvolvimento dessas características. Por exemplo: encorajar posturas abertas, novas visões e riscos; evitar estruturas rígidas; descentralizar a tomada de decisão e dar autonomia aos grupos ou departamentos (WOOD JR., 1992, p.15). 
É importante frisar que dependendo da área de atuação, do setor da empresa, do perfil dos funcionários e do contexto social, a escolha de uma abordagem mecânica ou orgânica é crucial para o bom funcionamento do sistema de trabalho.

Medeiros et al. (2011), citando Burns e Stalker (1960), lembram que as organizações mecânicas funcionam melhor em ambientes estáveis, enquanto as orgânicas se adaptam a ambientes turbulentos. No caso de cenários em transformação - como é o caso da EAD - é recomendável um misto de ambas.

Considerando todo o levantamento feito neste subcapítulo, percebe-se que a gestão dos funcionários de uma organização envolve mais do que simplesmente a utilização de ferramentas e processos. São escolhas cruciais de políticas, perfil, estilo de gerência e de relacionamento, que podem ter peso fundamental no sucesso ou fracasso de um setor ou até de uma instituição. É um trabalho complexo, que precisa analisar questões internas (pessoal, modelo de negócio) e externas (legislação, economia, política, mercado, cultura). De toda forma, pode-se dizer que o sucesso organizacional passará por conhecer seus funcionários e conhecer as características do seu trabalho. Com base nessas informações, deve-se escolher o estilo de gerência que una esses dois fatores da melhor forma possível.

A seguir, será abordada a escolha das estratégias e do perfil gerencial que atuem melhor na construção do material didático na EAD. Como visto no Capítulo 2 , essa construção é um trabalho calcado na criatividade necessária para a adap-

tação do conteúdo. É, também, atividade que demanda diálogo entre os pares e com a organização. Que exige conhecimento especializado e presteza para acompanhar a tecnologia e as mudanças sociais.

Quais ferramentas e qual estilo gerencial levantados neste capítulo melhor se encaixam na produção multidisciplinar de material didático? Quais as especificidades da montagem e gestão dessas equipes?

\section{3.}

\section{A montagem e o gerenciamento de equipes multidisciplinares em EAD}

Como visto até aqui nesta pesquisa, a evolução tecnológica e as TICs mudaram a educação, os materiais didáticos e a forma como eles são produzidos. Trouxeram a necessidade de formação de equipes multidisciplinares, compostas por profissionais variados que podem se agrupar em subequipes menores. Como lem- 
bram Mallmann e Catapan (2007, p. 64), a multidisciplinaridade permeia toda a concepção e desenvolvimento da EAD, pois a relação entre os atores é multidimensional.

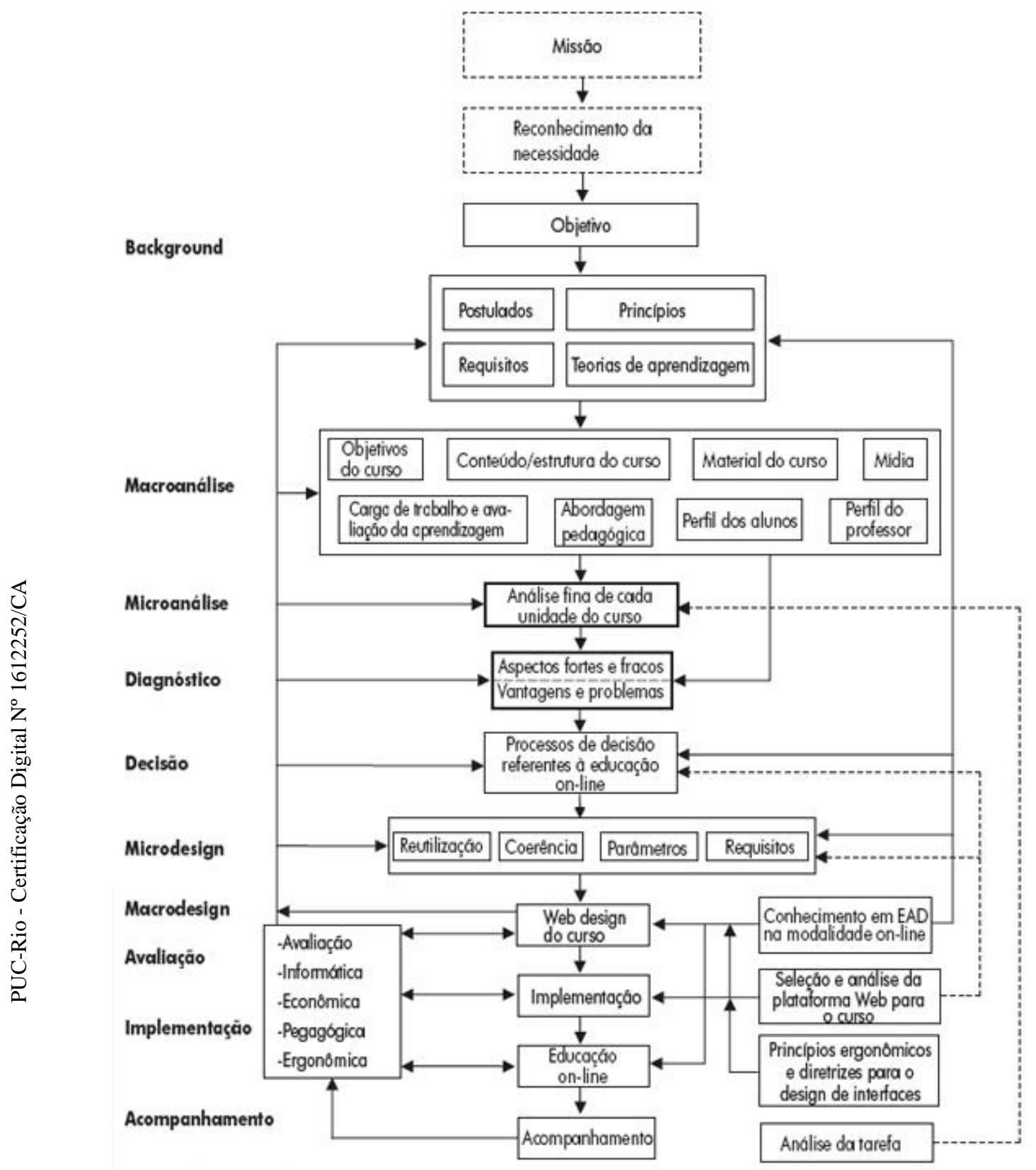

Figura 3.5 - Metodologia para concepção de cursos online (Fonte: GAMEZ, 2012, baseado em ROBERT et al., 2003)

Para ilustrar os diferentes elementos que compõem a montagem de um curso a distância, pode-se usar como exemplo o quadro de Gamez (2012, p.79) baseado na metodologia de Robert et al. (2003). O quadro identifica as etapas de um processo de concepção de cursos online, considerando a reutilização de materiais presenciais já existentes (Figura 3.5). Nele, percebe-se a quantidade de procedi- 
mentos e de conhecimentos específicos necessários na montagem de disciplinas EAD apresentadas pela internet.

Utilizando os conceitos de formação grupos de trabalho na EAD de Moreira (2009), pode-se também fazer um quadro que ilustra quais cargos e perfis são necessários, em geral, para a formação das subequipes que compõem o time multidisciplinar. É claro que a organização e o tamanho das instituições podem modificar essa estrutura, mas esta pesquisa exibirá o quadro como uma forma de exemplificar a complexidade desse arranjo organizacional.

É importante também ressaltar que um curso de EAD possui outros núcleos que dialogam com Departamento de Material Didático, como a Diretoria/Gestão, o Suporte Tecnológico e a Tutoria. Porém, por já estarem fora do escopo desta pesquisa, não serão incluídos no quadro abaixo (Tabela 3.5).

\begin{tabular}{|l|l|}
\hline SUBEQUIPE PROFISSIONAL & \multicolumn{1}{c|}{ PERFIL } \\
\hline Autores ou conteudistas & $\begin{array}{l}\text { Desenvolvem os conteúdos, selecionando e reunindo os materiais, } \\
\text { organizando e propondo dinâmicas, estratégias e recursos pedagó- } \\
\text { gicos. } \\
\text { O autor pode ou não acompanhar a tutoria da atividade ou estar } \\
\text { envolvido nos demais processos de desenvolvimento dos materiais. } \\
\text { Não é incomum que os conteúdos de um curso sejam elaborados } \\
\text { por diversos autores. Os profissionais envolvidos na autoria usual- } \\
\text { mente são professores universitários. }\end{array}$ \\
\hline Pedagógica & $\begin{array}{l}\text { Possui diferentes papéis no processo de EAD. } \\
\text { Pode coordenar os subsistemas de concepção, produção e avaliação } \\
\text { dos cursos; desenvolver pesquisas; promover discussões pedagógi- } \\
\text { cas; formar e acompanhar os tutores; dinamizar a comunicação; } \\
\text { assessorar a redação, a seleção e compilação de materiais didáticos, } \\
\text { entre outros. }\end{array}$ \\
\hline $\begin{array}{l}\text { Profissionais interdisciplinares, em especial nas áreas de educação, } \\
\text { comunicação e tecnologia. Acompanham o processo desde o plane- } \\
\text { jamento até a etapa de avaliação. } \\
\text { Em geral, fazem: levantamento e análise de necessidades de instru- } \\
\text { ção; levantamento do perfil dos alunos ou usuários; concepção e } \\
\text { planejamento do projeto; conversão ou adaptação dos conteúdos, } \\
\text { adequando-os à mídia a ser utilizada; definição de estratégias peda- } \\
\text { gógicas; colaboração com a autoria na programação de estratégias } \\
\text { de aprendizagem e avaliações e desenvolvimento de storyboards. }\end{array}$ \\
\hline $\begin{array}{l}\text { Responsável pela direção de arte, desenho gráfico, animações, } \\
\text { ilustrações, bem como outras características como a navegabilidade, } \\
\text { usabilidade e conformidade com os padrões internacionais. } \\
\text { Pode contar com diferentes profissionais, como web designers, } \\
\text { designers de interfaces, artistas gráficos, programadores, desenhis- } \\
\text { tas em 3-D, ilustradores ou outros. }\end{array}$ \\
\hline Arte \\
suctrucional
\end{tabular}

Tabela 3.5 - Características de subequipes envolvidas na produção de material didático em EAD (Fonte: Baseado em MOREIRA, 2009, p.373 e 374)

Qual seria a melhor forma de gerir essa equipe que se divide em várias, mas precisa ser uma só? Qual perfil de gerência fará com que apresente resultados 
consistentes com as características necessárias para a aprendizagem? A gestão correta do processo de produção do material é crucial para a EAD:

Em EaD o conceito de Gestão assume força central e singular no processo de elaboração dos materiais que contemplam todas as possibilidades didáticopedagógicas do curso. Pois, na concepção de uma proposta de curso na modalidade à distância a preparação do material é uma etapa de extrema importância. (...) A previsão das alternativas de interação é imprescindível para cada momento de aprendizagem que se fará autônomo, individual ou em grupos de estudantes (MALLMANN; CATAPAN, 2007, p.65).

Considerando-se o contexto da EAD, altamente impactado pela tecnologia, pode-se buscar a gestão de pessoas e de processos mais modernas e próximas a este tipo de cenário. Chiavenato $(1999$, p.40), ainda no fim do Século XX, já previa que as mudanças na sociedade demandariam dos gestores novas aptidões não só conceituais e técnicas, mas também novas habilidades humanas para lidar com suas equipes. Com isso, a gestão dos talentos e do capital intelectual numa organização também mudariam (Tabela 3.6):

- Uma nova visão do homem, do trabalho e da empresa.

- Estrutura plana, horizontalizada, enxuta, de poucos níveis hierárquicos.

- Organização voltada para processos e não para funções especializadas e isoladas.

- Necessidade de atender ao usuário - interno ou externo - e, se possível, encantá-lo.

- Sintonia com o ritmo e a natureza das mudanças ambientais.

- Visão voltada para o futuro e para o destino da empresa e das pessoas.

- Necessidade de criar valor e de agregar valor às pessoas, à empresa e ao cliente.

- Criação de condições para uma administração participativa e baseada em equipes.

- Agilidade, flexibilidade, dinamismo e proação.

- Compromisso com a qualidade e com a excelência de serviços.

- Busca da inovação e da criatividade.

Tabela 3.6 - As novas necessidades da administração de recursos humanos (Fonte:

Chiavenato, 1999, p.41)

Moreira (2009, p.371) concorda que os processos de produção se alteraram com as mudanças tecnológicas, políticas, econômicas, científicas e culturais. Citando Beloni (1999), a autora afirma que o sistema fordista não serve mais como parâmetro de funcionamento para a construção do material da EAD. A inovação demanda uma gestão de processos e pessoas mais integrada, como uma rede, que reflita "as novas formas de aprender em uma sociedade conectada".

Nesse contexto, Búrigo et al. (2016) também apontam que modelos próximos ao Fordismo não podem mais ser utilizados no campo multidisciplinar da EAD: 
Comumente os modelos de educação a distância são identificados com os modelos fordistas de produção industrial por apresentarem características semelhantes a este processo de produção. Exemplo dessa realidade é o enfoque de produção industrial proposto por Peters (2001), fundador e primeiro reitor da Fernuniversität, importante universidade aberta na Alemanha. A proposta é transpor para a educação a distância um ensino massificado, com divisão de tarefas e unidades estanques de produção. Nesta perspectiva, a EaD é concebida a partir de uma intensa racionalização do processo de ensino (PRETTO, 2005). Esta proposta apresenta pouca ou nenhuma comunicação entre as equipes, especialmente entre aqueles que produzem e aqueles que administram (BÚRIGO et al., 2016, p.167).

Como visto neste capítulo, o processo Fordista pressupõe a separação dos trabalhadores, fixando-os às suas tarefas específicas e alienando-os não só de uma visão em larga escala do processo, mas também das atividades dos colegas de trabalho. Para Búrigo et al. (2016, p. 167 e 168), a adoção desse tipo de modelo no âmbito da EAD não forma equipes, apenas reúne profissionais isolados que não compartilham ideias. Citando Almeida (2004), os autores sublinham que é preciso uma ação colaborativa corresponsável na construção de planos, propostas e material.

Moreira (2009, p.372) cita Asanome (2001) ao considerar que o que diferencia pessoas apenas trabalhando em conjunto de uma equipe propriamente dita é participação global de cada indivíduo, olhando sua atividade na perspectiva geral do processo e do resultado a ser entregue ao seu final. É o empenho e a satisfação. Ainda segundo a autora:

Stewart (1998) analisa a evolução da organização, afirmando que "onde antes havia pirâmides, patrões, departamentos, tropas, agora há redes, nós, agrupamentos, bandos. Nas empresas cuja riqueza é o capital intelectual, as redes, não as hierarquias, são o desenho organizacional mais adequado" (p.163-164). Essa visão fornece diretrizes claras para a criação de organizações capazes de aprender e considerar as TICs como ferramentas importantes para essa evolução, evitando as patologias do aprendizado do circuito único. Para Nonaka e Takeuchi (apud Basso, 2003), o processo por meio do qual o novo conhecimento é criado dentro das organizações sob a gestão de novos produtos, serviços ou sistemas - torna-se a pedra fundamental das atividades inovadoras (MOREIRA, 2009, p. 372).

Deve-se atacar a hierarquização e a fragmentação que acometem, muitas vezes, o processo de construção da equipe e o modelo de produção. Com isso, buscar "espaços que promovam a decisão e o compartilhamento das informações" (BÚRIGO et al., 2016, p.169). 
Assim, a multidisciplinaridade não precisaria ser encarada como uma demanda ou uma dificuldade para o processo, mas como um bônus. Silva e Santos (2012, p.156) citam Pinho (2006) ao lembrarem que a diversidade de uma equipe pode, também, ser uma ferramenta de promoção de novas visões e abordagens de trabalho. E o material didático para ensino a distância - que deve cumprir estratégias pedagógicas e ser capaz de potencializar a educação - precisa desse tipo de ação coletiva. Moreira (2009, p. 370 e 371) corrobora essa visão, ao afirmar que "a gestão dos componentes pode favorecer a aprendizagem colaborativa e permanente da equipe, retroalimentando os processos de aprendizagem da própria instituição e a recontextualização de seus conceitos e práticas".

Ainda segundo Moreira (2009), pode-se considerar quatro enfoques para a composição de equipes, quando se fala em elaboração de EAD. Citando Stone (apud Rumble, 2003), a autora diz que a interação entre os especialistas fica comprometida, na organização das equipes, quando se escolhe o Enfoque por especialidades ou por cadeia de montagem (Tabela 3.7).

\begin{tabular}{|l|l|}
\hline \multicolumn{1}{|c|}{ ENFOQUE } & \multicolumn{1}{c|}{ CARACTERÍSTICAS } \\
\hline Enfoque por especialidades & $\begin{array}{l}\text { Diferentes perfis de especialistas separados entre si, como } \\
\text { numa linha de montagem. }\end{array}$ \\
\hline Enfoque por cadeia de montagem & $\begin{array}{l}\text { Igual ao anterior, mas aqui cada especialista trabalha com } \\
\text { aquele que constitui o elo da cadeia produtiva. }\end{array}$ \\
\hline Enfoque por equipes interdisciplinares & $\begin{array}{l}\text { Diferentes perfis de especialistas se reúnem, assumindo a } \\
\text { elaboração e produção do projeto ou do curso conjuntamen- } \\
\text { te. }\end{array}$ \\
\hline $\begin{array}{l}\text { Enfoque por equipes de especialistas sob a } \\
\text { coordenação de um diretor do projeto }\end{array}$ & Todos atuam em conjunto em uma instituição. \\
\hline
\end{tabular}

Tabela 3.7 - Quatro enfoques para a organização e gestão da elaboração de cursos a distância relacionados à composição das equipes (Fonte: Baseado em Moreira, 2009, citando Stone apud Rumble, 2003)

Para Búrigo et al. (2016, p.169) é essencial que os profissionais troquem experiências e conhecimento sobre os processos de EAD. Especialmente entre os profissionais de perfil pedagógico e tecnológico. Conhecer as ferramentas permite aos pedagogos construir e demandar melhores veículos de aprendizagem. Do outro lado, identificar e entender as necessidades educacionais permite um melhor desenvolvimento tecnológico de ferramentas e de produtos hipermídia.

Além das questões profissionais, a experiência tácita e pessoal de cada pessoa também pode agregar valor ao grupo multidisciplinar. Moreira (2009, p.372) ressalta que cada componente traz consigo um universo particular: personalidade, vivências culturais, experiências de trabalho. Ainda segundo a autora: 
Caldwell (apud Parker, 1995) afirma que as equipes bem-sucedidas combinam conjuntos de habilidades que nenhum indivíduo isolado possui, participam do desenvolvimento de produtos nos quais os integrantes de diferentes departamentos e especialidades se reúnem sob a supervisão de um gerente e têm a responsabilidade de tomar decisões relativas ao desenvolvimento e de angariar o apoio de toda a empresa a essas decisões. (MOREIRA, 2009, p. 372)

É importante relembrar que os ganhos da multidisciplinaridade dependem da forma como a organização constrói e gerencia a equipe. Excelentes profissionais podem produzir resultados abaixo de seu potencial, se trabalharem num ambiente ou modelo inadequados. Considerando-se esses conceitos, pode-se concordar com Mallmann e Catapan (2007, p.65) quando afirmam que a organização deve escolher metodologias de gestão que construam um campo de atuação flexível. Esse campo deve estar de acordo com as competências profissionais dos envolvidos. Pois, como lembra Moreira (2009, p. 374), o conceito pedagógico e o modelo de gestão partem das organizações. E eles influem na definição dos papéis e na distribuição e funcionamento de equipes.

Por isso, a equipe multidisciplinar deve ser gerida e produzir num contexto e modelo onde o respeito e a cumplicidade entre os profissionais floresçam. Onde o diálogo entre as pessoas (e a organização) possa se refletir no diálogo do material didático com o mundo e com os alunos. Para que se atinja esse objetivo, é necessário conhecer o perfil pessoal e profissional de cada elemento. É preciso entendêlos, e construir um cenário onde possam render e dialogar, trazendo ganhos para toda a equipe. Essa questão passa por uma das predições desta pesquisa, na qual conhecer os atores e suas interações no processo multidisciplinar é tão importante quanto se debruçar sobre a interação e o perfil do usuário final. Mallman e Catapan (2007, p.66) corroboram essa importância, ao dizerem que "numa equipe multidisciplinar, em EaD, atributos como o diálogo e a participação ativa de todos os envolvidos são essenciais".

Em resumo, este capítulo buscou contextualizar os diferentes sistemas produtivos e sua relação com a formação de equipes de trabalho. Também buscou mostrar algumas políticas e perfis organizacionais e como eles podem influir no desempenho dos funcionários. Considerando as particularidades do trabalho multidisciplinar em EAD, foi mostrado que a produção do material didático perde ao ser abordada como uma linha de montagem fordista. Mesmo quando feita em larga escala, as especificidades contextuais, pedagógicas, o perfil dos profissionais 
e a necessidade de integração entre os atores envolvidos demandam uma gestão mais flexível da produção do material.

Neste processo, serão necessárias ferramentas para conhecer esses funcionários e para escolher o método de gestão que melhor se encaixe a eles. Ferramentas que levem em conta os perfis, o cenário externo e as características da organização. Ferramentas que incluam os profissionais, que abordem suas dificuldades cotidianas, que perguntem a eles como os processos podem melhorar. E essas respostas podem vir através da aplicação de metodologias colaborativas do Design e da Ergonomia Organizacional, como a Macroergonomia.

No próximo capítulo, essas metodologias serão abordadas e suas características e ferramentas serão descritas. Também será abordado qual o diferencial que seu uso pode trazer em relação aos métodos tradicionais de Gestão, especialmente no contexto multidisciplinar e dialógico da EAD, que pressupõe interação e colaboração entre os atores envolvidos. 


\section{4 \\ O Design e a Ergonomia aplicados em questões organiza- cionais}

Neste capítulo serão expostas as abordagens de metodologias como o Design Participativo, o Design Thinking e a Macroergonomia e qual o seu diferencial quando aplicadas no campo organizacional. A pesquisa buscará mostrar que essas metodologias, apesar de suas particularidades, têm uma visão comum centrada no ser humano e nos ambientes internos e externos que o cercam. Essa visão será comparada aos modelos organizacionais da Administração e contextualizada no trabalho multidisciplinar em EAD. Com isso, a pesquisa buscará o embasamento teórico para responder a sua questão norteadora: como utilizar o Design e a Ergonomia para construir, colaborativamente, uma proposta de mudança de cultura organizacional, de gestão de pessoas e de processos em ambientes multidisciplinares em Educação a Distância?

\section{1. O Design e a Ergonomia como ferramentas de mudança organizacio- nal}

O uso do Design e da Ergonomia na gestão de organizações foi e é um processo evolutivo natural. As mudanças sociais, econômicas e tecnológicas demandaram desses dois campos perspectivas de abordagem e de ação mais amplas, se debruçando sobre questões cada vez mais complexas - inclusive no campo organizacional. Buchanan (2004, p.54) avalia que gerenciar uma organização através dos conceitos do Design ainda pode parecer confuso para muitas pessoas. Até hoje, o Design é visto popularmente como uma atividade artística e associada à símbolos gráficos, produtos industriais, espaços interiores e edifícios. Porém, o autor defende que o Design é na verdade uma atividade intelectual e humanista, que busca criar soluções práticas e efetivas na melhora da vida humana em todos os seus aspectos. Inclusive, como veremos, os organizacionais. 
O Design é humanista porque se concentra na experiência humana dos produtos. É intelectual porque exige o conhecimento direto ou indireto de todos os fatores que devem ser integrados em um produto bem-sucedido, seja o produto como uma comunicação, um artefato, um serviço ou uma atividade de gerenciamento ou um ambiente. O Design oferece busca e resolução de problemas na vida prática através da criação de produtos que tenham integridade intelectual e satisfação emocional e estética (BUCHANAN, 2004, p.54, traduzido pelo autor).

\subsection{1. \\ O Design aplicado em questões organizacionais}

Para Brown (2010, p.7), o Design teve o seu papel aumentado e passou a despertar mais interesse da sociedade graças às mudanças no eixo econômico do mundo, que se moveu da produção industrial para a criação de conhecimento e a prestação de serviços. Buchanan (2015, p.16) lembra que o Design, no princípio, abordava problemas surgidos no projeto de produtos e serviços. Depois, passou a se relacionar mais profundamente com as questões operacionais das organizações. Por fim, os preceitos do Design foram utilizados para projetar o âmago das organizações e sua principal ponte com o mundo exterior: a visão e estratégia.

O mesmo Buchanan (2015, p.11 e 12) ilustrou esse processo gradual de evolução através do conceito das Quatro Ordens do Design. Nele, o autor divide a prática do Design em quatro áreas de "problemas de design" que seriam: comunicação; construção; interação; e integração. Cada uma dessas áreas se relaciona às diferentes questões abordadas pelos designers ao longo do tempo. As Quatro Ordens seriam, então, uma matriz que mostra a ação e atuação do Design sobre cada um desses problemas (Figura 4.1).

A primeira ordem seria o Design gráfico, surgido das questões de comunicação em massa do início do século XX, com textos e imagens para publicações impressas, cartazes e comunicação visual. A segunda ordem seria o Design industrial, uma consequência dos processos de produção massificada que necessitavam de soluções para os padrões, formas e mecanismos para o seu melhor funcionamento. A terceira ordem seria o Design de interação, uma demanda causada pela necessidade cada vez maior dos seres humanos de interagir com máquinas, interfaces e serviços. Por fim, a quarta ordem seria o Design de sistemas, e sua abordagem buscaria uma visão ainda mais ampla de tudo aquilo que o ser humano cria e com o que precisa interagir: os sistemas, o ambiente, as organizações (BUCHANAN, 2015, p.11 e 12). Se a evolução da presença do Design pode ser justi- 
ficada pelas mudanças do mundo, Cavalcanti (2015, p.64) enxerga também na trajetória explicitada pelas Quatro Ordens um aumento gradual da preocupação com os aspectos humanos e sociais.

\begin{tabular}{|l|l|l|}
\hline Ordem do Design: & Problema de Design: & Relaciona-se a: \\
\hline 1- Design gráfico & Comunicação (símbolos) & Palavras e Imagens \\
\hline 2- Design industrial & Construção (objetos) & Objetos físicos \\
\hline 3- Design de interação & Interação (ações) & Atividades, serviços e processos \\
\hline 4- Design de sistemas & Integração (pensamentos) & Sistemas, organizações, ambientes \\
\hline
\end{tabular}
Tabela 4.1 - As Ordens do Design e os problemas de Design abordados por elas (Fonte: baseado em BUCHANAN, 2015)

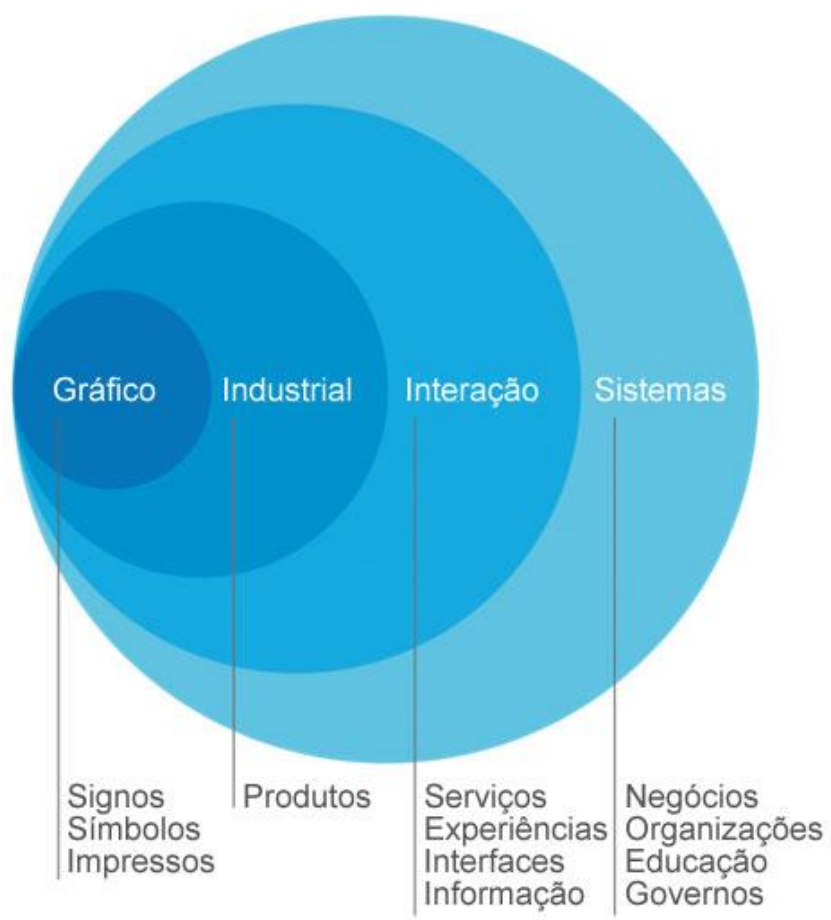

Figura 4.1 - As Quatro Ordens do Design e suas áreas de atuação (Fonte: baseado em BUCHANAN, 2015)

Por essa ótica, o Design de sistemas seria o âmbito principal da aplicação dos conceitos do Design na questão organizacional. Ele busca compreender as ideias por trás da comunicação, da construção e da interação. Ou seja, as ideias por trás das outras três ordens. O seu foco é no estudo da interdependência entre várias partes independentes. A visão do papel do designer defendida na Quarta Ordem é a base, o ponto de partida, da abordagem do Design sobre a questão organizacional (BUCHANAN, 2015, p.11 e 12). 
O design de hoje se dedica a evoluir seus métodos para lidar com problemas em nível de sistema. Problemas que não existiam antes e que são, em muitos casos, fruto do design em seus moldes tradicionais. (...) O design hoje enfrenta complexidades que o impede de manter-se focado somente no produto e seu meio de produção. (...) A condução de um projeto de design que hoje envolve a solução de problemas dessa ordem de complexidade exige, por consequência, a aplicação de métodos atuais, baseados na visão do design como transformador de situações (SILVA, 2012, p.15).

É preciso enxergar o ato de "fazer design" como o ato de projetar. Demarchi, Fornasier e Martins (2011) lembram que o Design representa tanto o processo de fazer alguma coisa, como o produto desse processo.

Niemeyer (1997) diz que a palavra inglesa design deriva do verbo latino designo, cujo sentido é designar, indicar, representar, marcar, ordenar, regular. Design significa projeto, configuração, distinguindo-se da palavra drawing - desenho, representação de formas por meio de linha e sombra. Essa distinção também ocorre no espanhol, porém, não no português (DEMARCHI; FORNASIER; MARTINS, 2011, p.26).

Mozota (2011) enfatiza que o Design não pode ser visto apenas pela ótica do resultado estético, pois ele também se debruça sobre questões de consistência, qualidade, forma e criatividade. $\mathrm{O}$ desenvolvimento de conceitos e especificações feito pelo designer traz também ganhos de função e valor, beneficiando usuários e organizações.

Assim, teoricamente, tudo passível de ser projetado pode ser abordado pelo designer e pelos seus preceitos: um cartaz, uma cadeira, uma interface, uma experiência de serviço ou o organograma de uma empresa.

Brown (2010, p.7) entende que, atualmente, temos grande necessidade de novos tipos de processos, serviços, interações e meios de comunicação e colaboração. E, segundo o autor, são exatamente esses os campos abordados pelo designer no seu cotidiano. Por essa lógica, a inovação se torna uma estratégia de sobrevivência, e o designer, um personagem fundamental para esse processo. Com essa visão em mente, percebeu-se que as organizações, em si, também poderiam ser tratadas como um projeto de design, se beneficiando de suas metodologias e preceitos. Para Demarchi, Fornasier e Martins (2011, p.28), por exemplo, o designer compatibiliza não só as técnicas, mas principalmente o planejamento e os fatores humanos para a resolução de problemas e verificação de oportunidades, caracterizando uma distinta forma de pensar o Design como ferramenta estratégica. 
Na mesma linha, Mozota (2011) diz que a natureza do Design muda: não mais envolvido num projeto ou produto, passa a atuar ajudando a coordenar funções, motivar e melhorar a comunicação em uma equipe de projeto, ligando-se à gestão de processos da organização e à gestão da inovação.

Pode-se relacionar essa concepção com a visão de design thinking de Brown (2010). Segundo ele, o Design deixa de ser apenas operacional para se tornar estratégico, conseguindo prover formas de integrar equipes, transformando o que é multidisciplinaridade em interdisciplinaridade.

Senge (apud BUCHANAN, 2015) considera que o novo papel dos líderes pode ser o de um gestor que é também pesquisador e designer. Pesquisador no sentido de entender a organização como um sistema que possui forças de mudança internas e externas, e designer enquanto projetista do processo de ensino que levará os demais gestores a entender essas forças. Buchanan (2015, p.12) corrobora essa visão, ao defender que a gestão é uma extensão natural desse novo Design. Isso ocorreria, pois gerir uma organização é buscar a sua unidade e coerência. $\mathrm{O}$ papel do gestor é criar ambientes - tanto conceituais quanto físicos - favoráveis, que facilitem a todos alcançarem seus objetivos. O gestor, assim como um desig$n e r$, seria o responsável não só por projetar o mundo que existe dentro da organização, mas também o mundo que existe para os outros além dela - a vida social ao redor de todos.

Todas essas questões são bastante abordadas pelos pesquisadores da Gestão do Design (Design Management). Holland e Lam (2014, p.21 e 22) citam Cooper e Press (1995) ao dizerem que gestão do design é sobre definir objetivos e propostas que tornem a abordagem do Design parte do gerenciamento, da estratégia, da tática e da operação da organização. Em seguida, os processos de gestão (planejamento, organização, implementação, monitoramento e avaliação) seriam aplicados para garantir que os objetivos e propostas vindos do Design sejam atingidos. Ainda segundo os autores, ocorrendo a convergência entre os dois campos, o Design deixa de ser exclusividade do projetista para se tornar um modo de vida da organização. Do outro lado, os gestores envolvidos devem tomar parte desse novo processo, e não simplesmente aceitá-lo. Para desempenhar esse novo papel, os designers devem compreender as necessidades gerenciais dos negócios e organizações, e devem dar suporte aos gestores estratégicos (Tabela 4.2). 


\begin{tabular}{|l|}
\hline \multicolumn{1}{|c|}{ Atitudes e ações do designer no campo estratégico } \\
\hline $\begin{array}{l}\text { Entender as questões envolvidas na tomada de decisão gerencial: olhar além do design; trazer ideias } \\
\text { e melhorias, mas sem esquecer o contexto e a realidade ao redor; }\end{array}$ \\
\hline $\begin{array}{l}\text { Encontrar a posição onde pode agregar mais valor: o designer não deve se portar como um artista, } \\
\text { uma "diva", e sim ter uma atitude madura onde possa agregar mais valor ao usuário; }\end{array}$ \\
\hline $\begin{array}{l}\text { Saber se comunicar na linguagem gerencial: gestores e designers precisam se comunicar e tentar se } \\
\text { compreender. Designers podem usar recursos visuais para facilitar o processo; }\end{array}$ \\
\hline $\begin{array}{l}\text { Usar as ferramentas do Design para trazer ideias e inovações: desenvolver habilidades e metodolo- } \\
\text { gias que tragam insights profundos e ajudem a organização a se diferenciar; }\end{array}$ \\
\hline $\begin{array}{l}\text { Usar o "pensamento de design" para ajudar os gestores: a abordagem do Design pode ajudar a plane- } \\
\text { jar e aprimorar produtos, de acordo com as necessidades e desejos dos usuários; }\end{array}$ \\
\hline $\begin{array}{l}\text { Usar o engajamento com o usuário para identificar prioridades: designers precisam entender os } \\
\text { usuários, e seus perfis, para avaliar as "questões-chave" de um produto ou serviço; }\end{array}$ \\
\hline $\begin{array}{l}\text { Usar o "pensamento de design" para ajudar os gestores no projeto dos seus sistemas: trazendo, } \\
\text { assim, coerência, consistência e alta qualidade para todos os processos; }\end{array}$ \\
Tabela 4.2 - Atitudes e ações do designer inserido no campo do Design estratégico e de \\
Gestão (Fonte: baseado em HOLLAND; LAM, 2014)
\end{tabular}

O grande diferencial desse novo papel do Design seria fazer com que elementos pouco notados pelas análises tradicionais de gestão sobressaíssem, gerando resultados diferenciados. Brown (2010, p.17), por exemplo, sublinha que um processo pensado pela lógica do Design, por ser neutro e iterativo, atinge resultados que visivelmente diferem dos processos lineares tradicionais.

Quando um problema típico de uma área é visto pela ótica de outra acontece um reposicionamento conceitual que levanta questões realmente novas e que apontam para uma solução inovadora (SILVA, 2012, p.17).

Para Boland Jr. e Collopy (2004, p.4), os estudos tradicionais de gestão e administração são voltados à construção de atitudes decisórias para a resolução de problemas. Parte-se do princípio que o gestor será colocado diante de várias possibilidades de ação e terá a difícil missão de decidir qual é a melhor. Já uma abordagem com "atitude de design" defenderia que é complexo, sim, projetar uma boa alternativa, mas, uma vez que esta é desenvolvida, a decisão torna-se corriqueira.

Por atitude de design, nos referimos às expectativas e orientações trazidas para um projeto de design. Uma atitude de design vê cada projeto como uma oportunidade para a inovação que inclui um questionamento de suposições básicas e uma determinação em tornar o mundo um lugar melhor do que o encontramos (BOLAND JR.; COLLOPY, 2004, p.9, traduzido pelo autor).

Ainda segundos os autores, a atitude decisória tradicional supõe que as possibilidades de ação já estão prontas, disponíveis, ou que são de fácil obtenção. Assim, o gestor desempenharia um papel passivo, pois consideraria que as alternativas já existentes, ou as primeiramente pensadas, estão entre as melhores possí- 
veis. Essa perspectiva levaria a resultados organizacionais "condenados à mediocridade" (aspas deste autor), pois não seria realístico pensar que as melhores opções, invariavelmente, já estão disponíveis (BOLAND JR.; COLLOPY, 2004, p.6).

Numa atitude de design, o custo de não conceber um curso de ação melhor do que os que já estão sendo considerados é muitas vezes bem maior do que fazer a escolha "errada" entre eles (BOLAND JR; COLLOPY, 2004, p.4, traduzido pelo autor).

Portanto, numa "atitude de design" organizacional, invariavelmente novas alternativas deverão ser projetadas (BOLAND JR; COLLOPY, 2004, p.6). O papel da criação, da inovação e da criatividade nessa nova abordagem do Design são também bastante destacados pelos teóricos do Design Thinking. Cavalcanti (2015, p.71 e 72), cita Welsh e Dehler (2012) na definição do Design Thinking como uma abordagem que busca solucionar problemas complexos e que coloca o ser humano no centro do processo. Isso se daria através de catalisação da inovação e da busca por soluções inovadoras através de observação e colaboração. $\mathrm{O}$ autor faz referência a Lloyd (2013) ao afirmar que o Design Thinking permite que equipes multidisciplinares usem os métodos de design como ferramentas para busca de soluções de problemas complexos em diferentes níveis - sociedade, educação e trabalho, por exemplo (CAVALCANTI, 2015, p.64). Alguns atributos que permeiam o Design Thinking foram compilados por Baeck e Gremett (2011) e resumidos por Cavalcanti (2015, p.74). Eles podem ser interessantes na busca por uma guideline para a abordagem e o pensamento em comum das diversas metodologias do Design aplicáveis no espectro organizacional (Tabela 4.3).

\begin{tabular}{|l|l|}
\hline \multicolumn{1}{|c|}{ Atributo } & \multicolumn{1}{c|}{ Descrição } \\
\hline Ambiguidade & Capacidade de lidar com situações complexas e cuja solução não é clara. \\
\hline Colaboração & Trabalho em equipe durante o desenvolvimento de projeto que busca por soluçães. \\
\hline Construção & $\begin{array}{l}\text { Criação de novas e melhores ideias que são construídas a partir de ideias existentes. } \\
\text { No Design Thinking, as soluções concebidas podem ser novas ou incrementais. }\end{array}$ \\
\hline Curiosidade & $\begin{array}{l}\text { Aproximação de situações e temas, a partir de uma visão curiosa, que muitas vezes são } \\
\text { desconhecidos. }\end{array}$ \\
\hline Empatia & Capacidade de ver e entender um problema a partir do ponto de vista do outro. \\
\hline Holístico & Precisa-se enxergar o contexto que está sendo estudado de forma integral e holística. \\
\hline Iterativo & $\begin{array}{l}\text { Adoção de um processo cíclico e não linear que visa a concepção de soluções ou ideias } \\
\text { inovadoras. }\end{array}$ \\
\hline Não crítico & $\begin{array}{l}\text { Criação de um ambiente onde as pessoas possam conceber e propor novas ideias sem } \\
\text { serem criticadas por outros membros da equipe de trabalho. }\end{array}$ \\
\hline Flexível & $\begin{array}{l}\text { Abordagem adotável em praticamente qualquer contexto, já que seu processo, min- } \\
\text { dsets, métodos e ferramentas são aplicáveis a diversas situações. }\end{array}$ \\
\hline
\end{tabular}

Tabela 4.3 - Atributos do Design Thinking. (Fonte: CAVALCANTI, 2015, adaptado de BAECK; GREMETT, 2011) 
Brown (2010, p. 16) afirma que o que diferencia um "pensamento de design" da visão presente na Administração Científica é o pressuposto de que não há, para os designers, uma "melhor" forma, um caminho totalmente linear, fixo, de percorrer o processo. As descobertas que surgem num cenário de inovação podem levá-los a inserir novas variáveis ao processo ou até a reverem suas premissas. Ainda segundo Brown, um processo pensado pela ótica do designer não segue necessariamente passos ordenados, mas pontos de apoio que se sobrepõem e podem ser percorridos mais de uma vez, à medida que ideias e direcionamentos vão surgindo. Esses pontos seriam: Inspiração (o problema ou oportunidade que motiva a busca por soluções); Idealização (o processo de gerar, desenvolver e testar ideias); e Implementação (o caminho que é percorrido até a colocação em prática).

Buchanan (2015, p.14) compartilha dessa visão ao dizer que o "pensamento de design" pode ser também uma inquirição criativa (no inglês, Creative Inquiry): a disciplina e prática de "perguntar e responder questões centrais sobre a proposta, a forma, os materiais e a eficiência de um resultado desejado numa situação específica" (traduzido por este autor). Mas o que seria, nesse sentido, criatividade? Cavalcanti (2015, p.73), cita Reimann e Schiike (2011) ao lembrar que a criatividade envolve novidade (algo inesperado) e usabilidade (algo que é adaptável e adequado para resolver um problema em um determinado contexto). Por esse prisma, pode-se definir criatividade como "a capacidade de pensar de forma original para conceber produtos, processos, serviços e soluções de problemas".

No entanto, a criatividade, por si só, não é suficiente. Pew e Mavor (2007, p.189) afirmam que o Design é um processo inovador que não substitui a criatividade, mas que, de fato, fornece uma estrutura e um contexto em que a inovação pode ocorrer.

Essa estrutura e contexto poderiam vir das fronteiras e limitações que os projetos possuem. Brown (2010, p. 17 e 18) defende que não é possível criar design sem que haja restrições. $\mathrm{O}$ autor lembra que o primeiro estágio do processo de design é a identificação das restrições mais importantes e a definição dos critérios para sua avaliação. Para ele, essas restrições podem ser melhor visualizadas de acordo com três critérios: praticabilidade (o que é possível funcionalmente num futuro próximo); viabilidade (o que poderá se tornar parte de um modelo sustentável); e desejabilidade (o que faz sentido para as pessoas). Assim, o papel do de- 
signer é não só o de solucionar essas restrições, mas também o de colocar as soluções em equilíbrio harmonioso.

Em resumo, a criatividade precisa ser guiada, precisa de uma base e de um contexto. É a orientação dada pelo Design que torna isso possível, que leva a resultados inovadores e a soluções organizacionais duradouras e voltadas para a satisfação humana (BOLAND JR.; COLLOPY, 2004, p. 15).

Esta citada preocupação com a satisfação humana é a base conceitual do Design. A partir dela, diversas metodologias colocarão o usuário, o ser humano, não só como foco principal do processo, mas também como um agente de mudança e uma fonte de soluções para os problemas organizacionais. Pode-se, aqui, fazer referência aos conceitos do Design Centrado no Ser Humano (DCSH) e do Design Centrado no Usuário (DCU):

Oviatt (2006) e Chaves, Bittencourt e Taralli (2013) indicam que o DCSH está embasado em métodos e modelos que enfatizam, comunicam, estimulam e explicitam as características, capacidades e comportamentos inerentes ao ser humano permitindo que seus desejos, necessidades e experiências sejam o ponto de partida para a projeção de soluções, produtos e serviços (CAVALCANTI, 2015, p.65).

Garret (2011, p. 17) foi outro autor que propõe o Design Centrado no Usuário (DCU), definindo-o como uma prática que leva em consideração o usuário a cada passo do caminho de desenvolvimento de um produto (...). Também se encontra nessa abordagem a utilização de técnicas de pesquisa de usuário e observação de seu comportamento. Para coletar opiniões sobre atitudes gerais e percepções, são propostos questionários, entrevistas e grupos focais (MOURA, 2015, p.77).

Segundo Buchanan (2015, p.5), o diferencial que esse pensamento pode trazer para o campo organizacional vem de um princípio intrínseco do Design: o foco na qualidade da experiência de todos os servidos por uma organização. Segundo ele, a preocupação não deve ser apenas com a lucratividade, mas, também, com a melhora significativa da vida das pessoas. Esse princípio traz consigo uma grande dificuldade: como o Design pode influenciar as organizações para que busquem não somente a mudança do pensamento e do comportamento dos indivíduos, mas também um efeito positivo na vida das pessoas, num mundo cada vez mais complexo?

Brown (2010, p.19) segue a mesma linha, ao afirmar que o que diferencia e orienta a forma de pensar do Design é o foco nas necessidades humanas fundamentais, e não em "desejos efêmeros ou artificialmente manipulados". 
Segundo Carayon, Hoonakker e Smith (2012, p.536), pessoas de todos os níveis hierárquicos são recursos essenciais para o sucesso da organização. Além disso, os melhores sistemas de trabalho são aqueles projetados usando as necessidades e conhecimentos dos trabalhadores na sua gestão.

\begin{abstract}
A gestão através do Design é um processo colaborativo, não o trabalho de um maestro único e heróico. Métodos inovadores de colaboração entre fronteiras disciplinares, funcionais e organizacionais são essenciais para a concepção de novos produtos e processos de sucesso. Um bom diálogo e uma argumentação persuasiva, juntamente com a manipulação física de artefatos, contribuem para a qualidade das ideias de design (BOLLAND Jr; COLLOPY, 2004, p.17, traduzido pelo autor).
\end{abstract}

Dul e Ceylan (2010, p.14) compartilham dessa visão ao analisarem o trabalho de Shalley et al. (2004). Segundo os autores, todos os funcionários em uma organização podem produzir ideias novas e potencialmente úteis não só para produtos ou serviços, mas também procedimentos de trabalho e soluções para os problemas do dia-a-dia. O envolvimento dos usuários no processo é fundamental nas novas teorias de Gestão baseadas no Design (BUCHANAN, 2015).

A partir da participação, as pessoas assumem responsabilidades nas atividades de seu grupo. Assim, podem-se criar condições favoráveis à motivação das pessoas, à medida que lhes são dadas oportunidades, o que as faz contribuir com sua iniciativa e criatividade, visando aos objetivos organizacionais. (RAUPP; BEUREN, 2003, p.4)

A compreensão das características dos usuários, incluindo suas motivações, metas e estratégias e o contexto do trabalho, devem ser forças centrais para a especificação de todo o design do sistema e não apenas a interface do usuário. A vantagem de abordar o sistema como um todo é o reconhecimento de que uma organização é, por si só, um sistema e alguns projetos organizacionais podem apoiar melhor a missão e a visão da organização (Lytle, 1998) do que outras (PEW; MAVOR, 2007, p.139, traduzido pelo autor).

Pode-se explicar a importância da inclusão dos usuários através da visão do Design Participativo, que se caracteriza por projetar com o usuário ao invés de para o usuário (LIVARI apud SILVA, 2012), por considerar que este é a melhor fonte de informações e respostas sobre a questão a ser abordada pelo designer. Isso ocorreria, pois o usuário vivencia o objeto de estudo cotidianamente, tornando-o, assim, o grande conhecedor da situação (SILVA, 2012). 
Camargo e Fazani (2014, p. 145) afirmam que o Design Participativo pode ser considerado como uma complementação do Design Centrado no Usuário, que segundo Dervin (1986 apud CAMARGO; FAZANI, 2014, p. 145) aborda o estudo com o foco direcionado às formas de interação e ao perfil do usuário. Enquanto o Design Centrado no Usuário envolve o estudo dos usuários e o desenvolvimento de um sistema para o usuário, o Design Participativo envolve a participação dos usuários e o desenvolvimento de um sistema com o usuário (MOURA, 2015, p.79).

Segundo Pew e Mavor (2007, p. 169), o aspecto crucial do Design Participativo é o compartilhamento completo de conhecimentos diversos, bem como uma orientação para o aprendizado mútuo. A análise participativa ajuda a entender o contexto de trabalho, incluindo tecnologias e práticas. O Design Participativo, assim, fornece métodos para melhorar o estado do trabalho de várias maneiras. Todos os métodos são pensados para serem realizados em colaboração com os usuários, que irão correlatar o seu atual estado de atuação, co-analisar o andamento do trabalho e co-projetar as melhores práticas de trabalho e tecnologia para seu sistema.

Silva (2012) afirma que um projeto de Design Participativo deve se apoiar na valorização do conhecimento tácito. Designers devem interagir com os usuários até que eles externalizem este conhecimento, e, de posse dessas informações, utilizá-las como base para idealizar e avaliar possíveis soluções.

O conhecimento tácito é o domínio do artesão. É o saber fazer, difícil de ser formalizado ou descrito e por isso mesmo normalmente subvalorizado por métodos administrativos que tendem a substituir o domínio holístico do trabalhador sobre o processo por uma série de tarefas formalizadas, mensuráveis e de fácil aprendizado (...) (SILVA, 2012, p.24).

Silva (2012, p.24 e 25) também faz referência ao trabalho de Sanders (2002), onde a empatia com o usuário é resultado da apreensão do que ele comunica nos níveis explícito, observável, tácito e latente (Figura 4.2). Para isso, é preciso perceber os desejos e necessidades expressados nesses diferentes níveis. A verbalização não é suficiente, pois mostraria somente o que o usuário quer e consegue expressar. A observação do que o usuário faz - e de que forma - permite a percepção do seu conhecimento tácito. E para conhecer os seus desejos latentes, é preciso ter acesso aos sonhos e aspirações desse usuário para o seu futuro. 


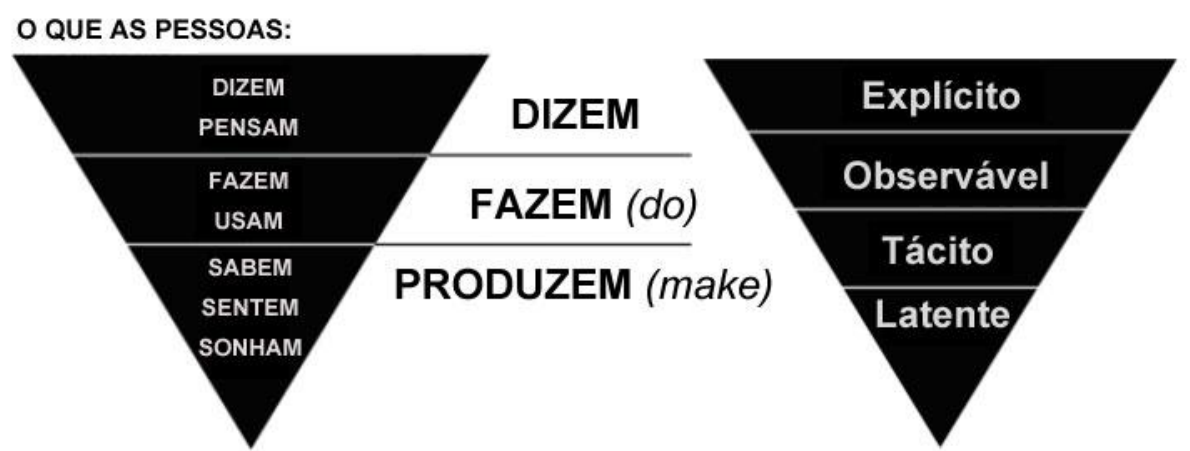

Figura 4.2 - Níveis de conhecimento e formas de expressá-los. (Fonte: SILVA, 2012, baseado em SANDERS, 2002)

Para atingir esse objetivo, os métodos de análise participativa deverão ser ferramentas diversificadas e criativas que ajudem os usuários a descrever seu trabalho, as organizações onde atuam, as tecnologias que utilizam no cotidiano profissional e seus contextos de trabalho (PEW; MAVOR, 2007, p.170). Entre essas ferramentas, pode-se citar mapas mentais, digramas, composições, colagens e esculturas, entre outras (SILVA, 2012).

Del Gaudio (2014), analisando as definições de Rizzo (2004) sobre o Design Colaborativo, também aborda o papel do designer como facilitador e condutor de um processo de criação coletiva e como responsável pela escolha das melhores ferramentas para o sucesso de um projeto colaborativo. Ainda segundo Del Gaudio:

\begin{abstract}
Uma vez que se trata de uma colaboração constante, contínua e paritária entre designer e usuário, a atividade é transparente; finalmente, neste processo o designer se coloca como facilitador, estimulador da criatividade, da capacidade de visão e da explicitação das necessidades inesperadas das pessoas. Ele faz isso projetando as ferramentas que ajudem o usuário a dar visibilidade e forma às ideias, muitas vezes usando e adaptando ferramentas das ciências sociais (DEL GAUDIO, 2014, p.44).
\end{abstract}

Na mesma linha, Pew e Mavor (2007, p. 173) sublinham que as metodologias participativas buscam métodos que não requerem habilidades ou conhecimento de tecnologia. O importante é ajudar os usuários a expressar o seu conhecimento exclusivo. Práticas que traduzam o mundo informal, contextual, concreto e rico dos usuários e do uso. As representações mais descontextualizadas, abstratas, "um pouco empobrecidas, mas poderosas", que podem ser utilizadas para análise de sistemas. 
Outro ganho da participação é a construção de uma relação de confiança com o usuário. Búrigo et al. (2016, p. 167 e 168), analisando as definições de Almeida (2005), dizem que a ação colaborativa vai além de compartilhar informações. É também uma elaboração conjunta de planos e proposta de ação. Isso traria confiança mútua, cumplicidade e comprometimento.

O perfil de cada organização, a cultura organizacional adotada e tipo de trabalho realizado podem demandar um maior ou menor nível de participação dos usuários num processo colaborativo. Por isso, é importante que o designer, ao abordar um sistema de trabalho, conheça a fundo as características da empresa, das tarefas e do ambiente interno e externo à organização. Assim, poderá escolher as melhores ferramentas e o nível adequado de envolvimento dos usuários no processo de design. Nesse sentido, vale ressaltar a categorização da progressão do nível de envolvimento do usuário de Cybis, Betiol e Faust (apud MOURA, 2015, p.80), detalhada na Tabela 4.4:

\begin{tabular}{|c|l|}
\hline Categoria & \multicolumn{1}{c|}{ Nível de envolvimento do usuário } \\
\hline Informativa & Usuário como fonte de informações - usa entrevistas, questionários e observação. \\
\hline Consultiva & $\begin{array}{l}\text { Usuário verifica e opina sobre as soluções projetadas pelo designer com base nos } \\
\text { dados informativos coletados - usa protótipos, maquetes. }\end{array}$ \\
\hline Participativa & $\begin{array}{l}\text { Organização transfere ao usuário o poder sobre as decisões de projeto - nível mais } \\
\text { elevado de participação. }\end{array}$ \\
\hline
\end{tabular}

Tabela 4.4 - Progressão do nível de envolvimento do usuário num projeto. (Fonte: CYBIS; BETIOL; FAUST, 2007)

Boland Jr. e Collopy (2004, p.18) lembram que uma solução de design só é realmente funcional se satisfizer os critérios de projeto de todos os que são afetados por ela. Isso incluiria "clientes, funcionários, vizinhos, públicos e futuras gerações”. Ainda segundo os autores, essa é uma busca sem fim, pois as demandas nunca conseguirão ser totalmente atendidas.

(...) qualquer esquema de otimização pode vir a ser de curta duração, porque as condições que foram consideradas na elaboração da otimização podem mudar (PEW; MAVOR, 2007, p. 140, traduzido pelo autor).

Por essa ótica, o envolvimento iterativo dos atores envolvidos é fundamental em qualquer processo organizacional baseado no Design. Moura (2015, p. 61), citando Vasconcelos et al., (2010), enxerga que os métodos de design foram aprimorados e se tornaram mais flexíveis, em adequação com os problemas e cenários 
atuais. Precisa-se de fluxos com mais retornos, fases mais detalhadas e novas técnicas diversas e multidisciplinares. Por isso, os métodos de design se tornaram mais iterativos, cíclicos e com várias fases de testes.

Assim, pode-se definir as características de uma abordagem sobre o pensamento, a atitude do Design aplicado sobre organizações. Nesta parte da pesquisa, foram referenciadas várias metodologias que, apesar de suas particularidades, trazem em comum uma visão sobre esse novo papel do Design. Na tabela abaixo, a pesquisa lista algumas características dessa visão, para depois serem comparadas e somadas à visão da Ergonomia organizacional.

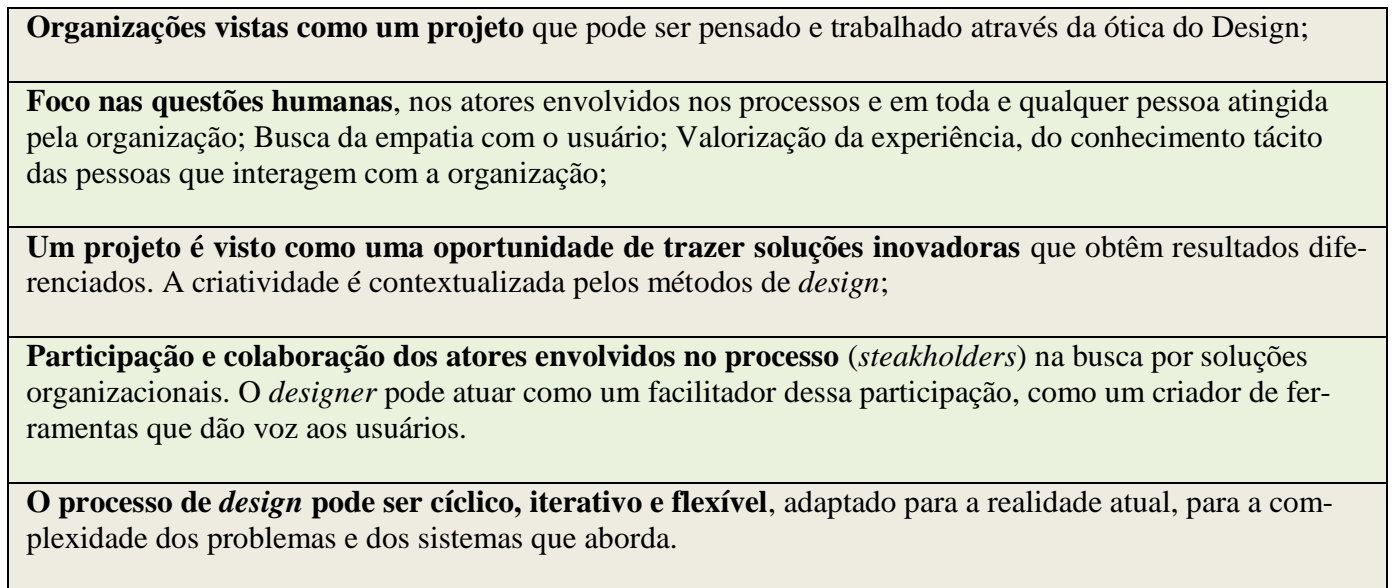

Tabela 4.5 - Características das metodologias de Design aplicáveis no campo organizacional (Fonte: $o$ autor, com base na pesquisa realizada.)

Enfim, os conceitos compilados neste capítulo, no âmbito do Design, talvez possam ser resumidos na definição de Brown (2010) sobre a necessidade de uma nova prática do Design:

As mudanças sísmicas que ocorrem em todos os setores demandam uma nova prática de design: colaborativa, mas de uma forma que intensifica, em vez de enfraquecer, os poderes criativos das pessoas; focada, mas ao mesmo tempo flexível e reativa a oportunidades inesperadas; concentrada não apenas na otimização dos componentes sociais, técnicos e de negócios de um produto, mas também em atingir equilíbrio harmonioso (BROWN, 2010, p. 35 e 36).

A seguir, a pesquisa abordará as características das metodologias organizacionais no campo da Ergonomia, e como elas podem ser reunidas com as do campo do Design. O objetivo desse levantamento é construir uma abordagem onde essas duas visões se complementem e possam trazer resultados diferenciados ao abordar equipes de trabalho multidisciplinares. 


\title{
4.1.2.
}

\section{A Ergonomia aplicada em questões organizacionais}

A Cultura Organizacional e a Gestão estão presentes no escopo da Ergonomia há algum tempo. Kleiner (2008) contextualiza que a abordagem dos sistemas de trabalho através da ergonomia começou na Europa pós-Segunda Guerra, advinda da necessidade de reconstrução do continente.

No entanto, a formalização de uma subdisciplina específica da Ergonomia voltada para a questão organizacional só viria anos depois. Na década de 1980, a Human Factors Ergonomics Society criou um comitê para analisar as tendências industriais dos próximos vinte anos, até 2000. Um dos focos do comitê foi a gestão dos sistemas de trabalho (HENDRICK; KLEINER, 2001) e o Design Organizacional. Além de previsões sobre o desenvolvimento da tecnologia do trabalho e das telecomunicações, o Comitê também avaliou as mudanças demográficas e de valores sociais. A conclusão do Comitê foi que a complexidade das mudanças, após vinte anos, exigiria uma presença maior da Ciência Ergonômica no Design Organizacional e na Gestão (em inglês, ODAM - Organizational Design and Management). Ao mesmo tempo, identificaram a necessidade da Ergonomia de absorver conceitos da ODAM, adotando uma visão mais ampla sobre sua atuação (KLEINER; HENDRICK, 2008).

\begin{abstract}
À medida que as organizações se tornavam mais complexas, formaram vários setores ou departamentos de especialização. Isso refletia a crescente complexidade da sociedade (...) as organizações de trabalho desenvolveram uma composição semelhante, com gerenciamento, finanças, segurança, fabricação, marketing, vendas, serviços ao cliente, transporte e recursos humanos. Essa complexidade levou a uma necessidade de estrutura, regras e procedimentos para fornecer operações efetivas e eficientes (CARAYON; HOONAKKER; SMITH, 2012, p.535).
\end{abstract}

Pela ótica da ODAM, deve-se construir uma cultura de processo de design e gestão organizacional onde se permita que as pessoas sejam motivadas, produtivas e eficazes, com qualidade de vida profissional e segurança. Para isso, é necessário ir de encontro às expectativas e necessidades das pessoas em uma organização. Os funcionários são a base de construção de uma organização sustentável, bemsucedida e saudável (CARAYON; HOONAKKER; SMITH, 2012, p.534). 
Medição do trabalho, eficiência, produtividade, qualidade, qualidade da vida profissional, demandas de emprego, gerenciamento de estresse físico e psicossocial, segurança e saúde dos trabalhadores formam um pacote completo para projetar e gerenciar o local de trabalho. No centro das abordagens da ODAM está o conceito de que os trabalhadores felizes, satisfeitos e não estressados serão trabalhadores saudáveis e produtivos (CARAYON; HOONAKKER; SMITH, 2012, p.537).

Os pesquisadores buscaram, constantemente, avaliar e projetar o trabalho através de métodos com bases científicas. Esse sistema foi bem recebido pelos funcionários, que viam nessa avaliação um método justo e sem viés. Isso permitiu a ampliação do escopo das questões humanas abordadas pelos gestores, a melhora no ambiente e nos padrões de trabalho e uma percepção mais nítida dos empregados sobre sua atividade profissional. Além disso, os aspectos sociais e informais também foram considerados. Lideranças e hierarquias informais podem influir no comportamento dos funcionários em assuntos como coesão entre as equipes e percepção dos trabalhadores sobre a organização (CARAYON; HOONAKKER; SMITH, 2012, p.536).

Desta forma, se aproximando mais desses conceitos da ODAM, a Ergonomia iria além do paradigma do operador interagindo com uma interface (KLEINER; HENDRICK, 2008).

\begin{abstract}
Historicamente, a disciplina da ergonomia se concentrou no empregado individual no nível do local de trabalho. Embora algumas pesquisas e práticas de fatores ergonômicos tenham levado em consideração as questões sociais e econômicas, eles geralmente não prestaram muita atenção ao meio ambiente (Steimle e Zink, 2006). Recentemente, abordagens macroergonômicas adotaram o sistema mais amplo no qual as pessoas trabalham, incluindo o meio ambiente (Hendrick e Kleiner, 2002) (CARAYON; HOONAKKER; SMITH, 2012, p.545 e 546, traduzido pelo autor).
\end{abstract}

Segundo Hendrick e Kleiner (2002, p.3), a Macroergonomia foca na interface entre Homem e Organização (no inglês, HOI - Human-Organization Interface) e nos fatores humanos, tecnológicos e contextuais (internos e externos à organização) que influem na hora de projetar e analisar sistemas de trabalho.

Pensar o projeto de interface das estações de trabalho individuais isoladamente já não é suficiente. Os sistemas complexos de hoje são operados por equipes de indivíduos cujas interações devem ser levadas em consideração. Mesmo pensar em sistemas únicos não é suficiente. Atualmente, existem requisitos para operar sistemas múltiplos - sistemas de sistemas - em interação uns com os outros (PEW; MAVOR, 2007, p.12, traduzido pelo autor). 
Assim, a Macroergonomia é o domínio que atua no projeto de sistemas de trabalho, e é reconhecida, desde a década de 1980, como a subdisciplina que foca na relação entre a Ergonomia e o Design Organizacional e a Gestão (HENDRICK, 2005, p.75-1).

\begin{abstract}
A Macroergonomia produziu resultados bem-sucedidos ao projetar sistemas de trabalho em áreas como saúde e manufatura. Este sucesso surge, em parte, através de eficazes métodos analíticos e de uma perspectiva que identificam e resolvem incompatibilidades de interface entre as capacidades humanas, o projeto de trabalho e as tecnologias e ferramentas (Hendrick, 2002) (WATSON et al. 2009, p.1042, traduzido pelo autor).
\end{abstract}

Segundo Kleiner (2008, p.461) o trabalho do Comitê e artigos científicos subsequentes resultaram em um conjunto de métodos, ferramentas e técnicas que visavam ir além dos $10 \%$ a $20 \%$ de melhora de performance atingidos pela ergonomia tradicional. A expectativa dos pesquisadores era que, se atendo corretamente aos fatores da ODAM, esse ganho poderia subir para de $60 \%$ a $80 \%$. Citando Bailey (1989), Hendrick e Kleiner (2008, p. 115) lembram que, tradicionalmente, a estrutura das organizações é direcionada pela tecnologia. Nesses casos, as máquinas recebem as tarefas que são capazes de fazer, e o que é "sobra" é atribuído aos trabalhadores. Essa situação pode acarretar em falta de motivação intrínseca dos indivíduos e em tarefas muito acima ou muito abaixo das habilidades humanas. Um sistema de trabalho planejado dessa forma não leva em consideração as características do Subsistema de Pessoal, nem do ambiente externo relevante que o permeia.

Existem muitos exemplos de sistemas que falharam completamente ou foram adotados apesar das suas inadequações (...) Muitas vezes, as razões pelas quais esses sistemas adotados foram considerados infrutíferos são porque eles não conseguiram atender aos requisitos dos usuários humanos - eles exigiam carga de trabalho não razoável, estresse psicológico e físico ou resultaram em erros humanos. Eles falharam porque seus desenvolvedores tinham uma compreensão inadequada ou negligenciaram a consideração das capacidades e limitações únicas das pessoas (PEW; MAVOR, 2007, p.12, traduzido pelo autor).

Desta forma, a Macroergonomia utiliza e adapta ferramentas e metodologias para o seu escopo: questionários, entrevistas semiestruturadas, pesquisa de campo, grupos de foco, entre outros. Também é possível simular sistemas de trabalho em laboratório, onde o ergonomista manipula variáveis sociotécnicas, ou o sistema 
em si, em busca de respostas (HENDRICK, 2005, p.75-2). Quando sistemas de larga escala precisam ser abordados, um framework macroergonômico pode organizar e triangular resultados de estudos em laboratório com dados de pesquisas de campo. Para isso, utiliza dados qualitativos e quantitativos e busca manter o foco tanto no contexto macro quanto no micro (KLEINER, 2008, p.465).

\begin{tabular}{|l|}
\hline Base teórica: Teoria dos sistemas sociotécnicos \\
\hline Foco principal: Organização dos sistemas de trabalho \\
\hline Focos secundários: Ambiente, pessoal, tecnologia \\
\hline Principal impacto na performance: Produtividade, saúde e segurança, satisfação, cultura \\
\hline $\begin{array}{l}\text { Valores adicionais e características agregáveis: Ponte entre o macro e o micro; melhor aplicada para } \\
\text { profissionais de ergonomia }\end{array}$ \\
Tabela 4.6 - Características gerais da Macroergonomia (Fonte: baseado em KLEINER, \\
2008)
\end{tabular}

Mas o que seriam sistemas de trabalho? Na definição do Conselho Internacional de Engenharia de Sistemas (no inglês, INCOSE), um sistema é uma "coleção de elementos diferentes que, em conjunto, produzem resultados que não podem ser obtidos pelos elementos isoladamente". Os elementos que formam os sistemas podem ser pessoas, hardware, softwares, instalações, políticas: todas as coisas necessárias para o sistema produzir qualidades, propriedades, características, funções, comportamento e desempenho. Ainda segundo o Conselho, o valor gerado por um sistema é resultado não só do que essas partes produzem isoladamente, mas, principalmente, do que é gerado pelo relacionamento entre essas partes (PEW; MAVOR, 2007, p.15).

As mudanças ocorridas nos últimos anos levaram cada uma dessas partes do sistema a serem consideradas sistemas por si só. Ou seja, dentro de um sistema existem outros (sub) sistemas, que devem ser encarados como tal (PEW; MAVOR, 2007, p.15). Os autores defendem, ainda, que a causa do mal funcionamento e insuficiência de muitos sistemas é que eles não são vistos como "sistemas de sistemas".

Para Walket et al. (2008, p.10), o grande problema ao se projetar e analisar sistemas de trabalho é que não se pode impor um comportamento determinista em uma organização e seu ambiente. As entidades interligadas em um sistema raramente mantêm-se em um estado fixo (como um "sistema fechado"). Esse comportamento mutável do sistema ocorre ainda mais em cenários de distúrbios externos. Quanto mais o determinismo é imposto, pior o problema se torna. 
Por isso, Kleiner (2008, p.462) lembra que a necessidade de enxergar um espectro maior dentro de sua área e de aumentar o ganho de produtividade levou a Macroergonomia a abordar os sistemas onde ela atua de forma mais ampla. Ela adotou, assim, conceitos da perspectiva dos sistemas sociotécnicos, especificamente a relação entre os subsistemas de Pessoal, Tecnológico, de Ambiente relevante e Organizacional. Ainda segundo Kleiner (2008), o ergonomista não precisa ser especializado nessas áreas, mas deve conhecer o suficiente para entendê-las e enxergar os fatores dentro do sistema que poderão contribuir, ou não, nas implementações e intervenções necessárias.

\begin{tabular}{|l|l|}
\hline \multicolumn{1}{|c|}{ Subsistema } & \multicolumn{1}{c|}{ Elementos do subsistema } \\
\hline Subsistema tecnológico & Ferramentas, métodos, equipamento, softwares \\
\hline Subsistema de pessoal & Pessoas necessárias para realizar o trabalho \\
\hline Subsistema de ambiente externo & $\begin{array}{l}\text { Elementos relevantes, externos à organização, aos quais ela } \\
\text { deve ter atenção }\end{array}$ \\
\hline Subsistema de ambiente interno & Características físicas e culturais da organização \\
\hline Subsistema organizacional & Estrutura organizacional e processos \\
\hline
\end{tabular}

Tabela 4.7 - Subsistemas presentes em um sistema sociotécnico de trabalho (Fonte: baseado em HENDRICK; KLEINER, 2008)

Para Walker et al. (2008, p.3), na teoria sociotécnica entende-se que a interação de fatores sociais e técnicos cria condições para o desempenho (bom ou ruim) do sistema. Parte dessas interações vem de relações lineares (e, em geral, projetadas) de causa e efeito; e parte de relações "não-lineares", complexas, imprevisíveis e até inesperadas.

Uma consequência inevitável de misturar "sócio" com "técnico" é que o sócio não se comporta necessariamente como o técnico, as pessoas não são máquinas, paradoxalmente, com crescente complexidade e interdependência, mesmo os "técnicos" podem começar a exibir comportamentos não lineares. Inevitavelmente, ambos os tipos de interação ocorrem quando um sistema sociotécnico é posto em prática (WALKER et al., 2008, p.3, traduzido pelo autor).

Um dos princípios dos sistemas sociotécnicos é que a otimização tanto dos aspectos sociais quanto dos técnicos (especialmente estes) em geral aumentam a quantidade de relações imprevisíveis, não-projetadas e não lineares. Além disso, aumentam as relações realmente prejudiciais ao desempenho do sistema. A teoria sociotécnica, portanto, buscaria uma "otimização conjunta" (no inglês, joint optimization) desses dois aspectos. Seu foco é, ao mesmo tempo, o melhor desempe- 
nho do sistema e a melhor experiência humana dentro dele. A teoria vê os dois aspectos como isomórficos (WALKER et al., 2008).

Os sistemas sociotécnicos tomam os conceitos e metáforas da teoria geral dos sistemas, em particular a noção de "sistemas abertos" (por exemplo, Bertalanffy, 1950), como uma forma de descrever, analisar e projetar sistemas com otimização conjunta em mente, particularmente aqueles que incorporam algum grau de nãolinearidade dentro de si, bem como no ambiente em que se encontram (WALKER et al., 2008, p.4, traduzido pelo autor).

Ainda segundo Walker et al. (2008, p. 20 e 21) um "sistema aberto" é aquele que faz fronteira com outros sistemas e realiza alguma forma de troca com eles. Citando Morgan (1986), os autores defendem que, se os sistemas sociotécnicos poderiam ser análogos a uma entidade viva, e "capazes de se adaptar e evoluir em mudanças ambientais e comportar-se mais como uma ecologia do que uma máquina".

Kleiner (2008, p. 465) expõe que muitos conceitos da teoria dos sistemas sociotécnicos, da joint optimization e da própria Macroergonomia não encontravam comprovações nem prescrições práticas na literatura. Por isso, estudos empíricos foram realizados em firmas americanas para quantificar e validar aspectos dessas teorias. Os resultados dessas pesquisas formam o corpo da base, o framework macroergonômico no qual se sustentam as metodologias específicas da subdisciplina. Entre essas metodologias, pode-se citar a Análise Macroergonômica de Estrutura (no inglês, MAS), a Análise e Design Macroergonômicos (no inglês, MEAD) e o Questionário Macroergonômico Organizacional (no inglês, $M a$ croergonomic Organizational Questionnaire Survey - MOQS).

Nessas metodologias, os pesquisadores analisam as características dos subsistemas que compõem o conjunto sociotécnico, estudam as relações entre eles, os efeitos sobre o sistema de trabalho e, com esses dados, desenvolvem projetos que corrijam e otimizem a estrutura de funcionamento (KLEINER, 2008, p.463).

Para melhor entendimento da forma macroergonômica de trabalhar a relação entre os subsistemas, pode-se analisar os métodos da MAS. Nela, a estrutura de um sistema de trabalho possui três dimensões principais, explicitadas na Tabela 4.8: a complexidade; a formalização; e centralização (Bedeian \& Zammuto, 1991; Robbins, 1983; Stevenenson, 1993). Os subsistemas do sistema de trabalho (Figura 4.3) são, assim, estudados em seus efeitos sobre essas três dimensões. O MAS 
busca integrar modelos selecionados como ferramentas para avaliar, modificar, ou mesmo desenvolver o projeto de um determinado sistema de trabalho (KLEINER, 2008, p.463).

\begin{tabular}{|c|l|}
\hline $\begin{array}{c}\text { Dimensões do sistema de } \\
\text { trabalho }\end{array}$ & \multicolumn{1}{|c|}{ Características da dimensão } \\
\hline \multicolumn{1}{|c|}{ Complexidade } & $\begin{array}{l}\text { - Foca na diferenciação (grau em que o sistema de trabalho está segmenta- } \\
\text { do em partes) e integração (mecanismos que são utilizados para integrar as } \\
\text { peças segmentadas para fins de comunicação, coordenação e controle) do } \\
\text { sistema de trabalho. } \\
\text { - A diferenciação pode ser vertical (mede a estrutura hierárquica da orga- } \\
\text { nização); horizontal (mede a especialização e a divisão departamental } \\
\text { dentro do sistema estudado) e espacial (mede se as atividades são realiza- } \\
\text { das em diferentes lugares). }\end{array}$ \\
- A integração mede o número de mecanismos projetados para um sistema \\
de trabalho assegurar comunicação, coordenação e controle entre os ele- \\
mentos diferenciados. Em geral, quanto mais um sistema de trabalho au- \\
menta em diferenciação, aumenta a sua necessidade de mecanismos de \\
integração.
\end{tabular}

Tabela 4.8 - Dimensões principais de um sistema de trabalho (Fonte: baseado em KLEINER, 2008, e em HENDRICK; KLEINER, 2008)

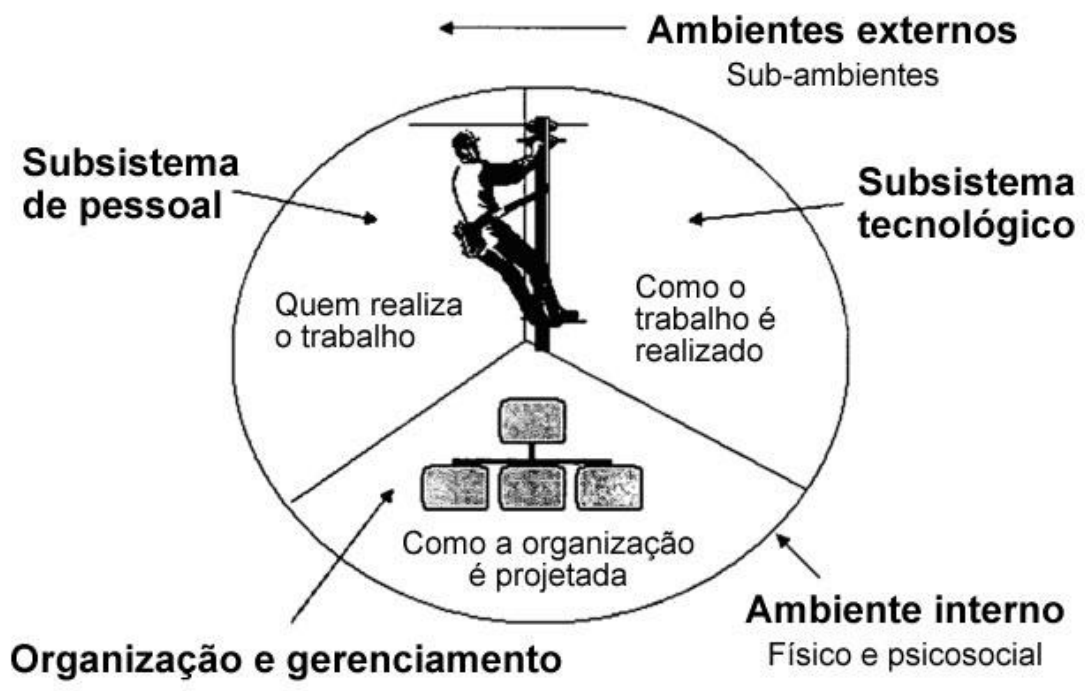

Figura 4.3 - Representação básica do conceito de sistemas de trabalho. (Fonte: baseado em KLEINER, 2008) 
Pode-se entender melhor os efeitos dessas dimensões sobre os subsistemas de trabalho observando-se a descrição das análises da MAS de Hendrick e Kleiner (2008). Na análise do subsistema tecnológico, por exemplo, a MAS usa o modelo de Perrow (1967) que relaciona a tecnologia (que o autor define como "a ação executada sobre um objeto para alterá-lo e que requer alguma forma de conhecimento técnico") com a estrutura do sistema de trabalho, numa classificação baseada no nível de conhecimento. Assim, Perrow identificou duas dimensões subjacentes: a variabilidade (o número de exceções encontradas no trabalho) e a analisabilidade (quais os procedimentos disponíveis para se pesquisar as respostas às exceções) da tarefa. Os procedimentos podem variar de "bem definidos" (no inglês, well-defined) - resolvidos com raciocínio racional, quantitativo e analítico a "mal definidos" (ill-defined) - sem procedimentos de pesquisa formal disponíveis e que demandam mais experiência, julgamento e intuição (HENDRICK; KLEINER, 2008, p.117).

Fazendo uma dicotomia entre as dimensões, Perrow (1967) chegou a uma matriz (Tabela 4.9) de quatro células que representam, cada uma, um tipo de tecnologia (Rotineira, Não-rotineira, de Engenharia e Artesanal) classificadas de acordo com o nível de conhecimento:

\begin{tabular}{|c|l|c|c|}
\hline \multicolumn{2}{|c|}{} & \multicolumn{2}{c|}{ Variabilidade da tarefa } \\
\cline { 3 - 4 } \multicolumn{2}{|c|}{} & $\begin{array}{c}\text { Rotineira com poucas } \\
\text { exceções }\end{array}$ & $\begin{array}{c}\text { Muita variação e muitas } \\
\text { exceções }\end{array}$ \\
\hline $\begin{array}{c}\text { Analisabilidade } \\
\text { do problema }\end{array}$ & Bem definido e analisável & Rotineira & Engenharia \\
\cline { 2 - 4 } & Mal definido e não analisável & Artesanal & Não-rotineira \\
\hline
\end{tabular}

Tabela 4.9 - Matriz do esquema de classificação de tecnologias de Perrow (Fonte: HENDRICK; KLEINER, 2008, baseado em PERROW, 1967)

\begin{tabular}{|l|l|}
\hline \multicolumn{1}{|c|}{ Tipo de tecnologia } & \multicolumn{1}{c|}{ Características do tipo de tecnologia } \\
\hline $\begin{array}{l}\text { Tecnologias rotineiras } \\
\text { (Routine Technologies) }\end{array}$ & $\begin{array}{l}\text { Têm problemas bem definidos com poucas exceç̃̃es (por exemplo, a pro- } \\
\text { dução em massa). A manutenção é bastante repetitiva. As tecnologias } \\
\text { rotineiras se prestam a uma coordenação padronizada e procedimentos de } \\
\text { controle. Associadas a alta formalização e centralização. }\end{array}$ \\
\hline $\begin{array}{l}\text { Tecnologias } \\
\text { não-rotineiras (Non- } \\
\text { routine Technologies) }\end{array}$ & $\begin{array}{l}\text { Têm muitas exceções e problemas difíceis de se analisar (por exemplo, } \\
\text { combate aeroespacial). Precisam de muita flexibilidade. } \\
\text { São altamente descentralizadas e com baixa formalização. }\end{array}$ \\
\hline $\begin{array}{l}\text { Tecnologias de } \\
\text { Engenharia (Engineering } \\
\text { Techologies) }\end{array}$ & $\begin{array}{l}\text { Têm muitas exceções, mas podem ser tratadas usando processos racionais. } \\
\text { Se prestam a centralização moderada e precisam da flexibilidade que é } \\
\text { possível através da baixa formalizção. }\end{array}$ \\
\hline $\begin{array}{l}\text { Tecnologias } \\
\text { Artesanais (Craft Techno- } \\
\text { logies) }\end{array}$ & $\begin{array}{l}\text { Envolvem tarefas bastante rotineiras, mas a resolução de problemas depen- } \\
\text { de fortemente da experiência, julgamento e intuição do artesão individual. } \\
\text { Assim, aqueles com a especialização necessária devem tomar decisões. } \\
\text { Requer descentralização e baixa formalização. }\end{array}$ \\
\hline
\end{tabular}

Tabela 4.10 - Tipos de tecnologia de um sistema sociotécnico (Fonte: HENDRICK; KLEINER, 2008, baseado em PERROW, 1967) 
Já a análise do subsistema de pessoal leva em consideração três fatores que devem ser considerados em um projeto de sistema de trabalho (Tabela 4.11): Nível profissional; Fatores culturais; e Aspectos psicossociais da força de trabalho (HENDRICK; KLEINER, 2008, p.117).

Por fim, a MAS analisa o subsistema do ambiente externo que é relevante para a organização. O sucesso das organizações é fortemente ligado à sua capacidade de adaptação ao ambiente externo.

A empresa e o meio ambiente terão um grande impacto sobre se um sistema é bemsucedido em cumprir a missão pretendida e é bem recebido. Hendrick e Kleiner (2001) afirmam que o ambiente é quatro vezes mais poderoso do que outros subsistemas como determinante do sucesso. Ao avaliar os contextos empresariais e ambientais no projeto inicial, a probabilidade de um resultado bem-sucedido será aprimorada (...). Um desafio é que o contexto inteiro não pode ser conhecido e, portanto, é difícil decidir quanto conhecimento contextual é suficiente (PEW; MAVOR, 2007, p.149).

Como sistemas abertos, as organizações exigem monitoramento para detectar mudanças externas e capacidade de se ajustar às necessidades (HENDRICK; KLEINER, 2008, p.118).

\begin{tabular}{|l|l|}
\hline $\begin{array}{l}\text { Fatores relevantes do } \\
\text { subsistema de pessoal }\end{array}$ & \multicolumn{1}{c|}{ Características dos fatores } \\
\hline $\begin{array}{l}\text { Nível de formação } \\
\text { profissional }\end{array}$ & $\begin{array}{l}\text { Onde o sistema de trabalho é projetado para permitir uma baixa formalização } \\
\text { (e o papel do empregado é maior), os trabalhos devem ser projetados para } \\
\text { exigir pessoas com um nível profissional relativamente alto. Na maioria das } \\
\text { vezes, é a necessidade de ter funcionários que possam lidar com coisas únicas, } \\
\text { não-rotineiras ou imprevistas que demandam baixa formalização e empregos } \\
\text { com mais exigência profissional. }\end{array}$ \\
\hline Fatores culturais & $\begin{array}{l}\text { É importante considerar os valores, percepções, costumes e atitudes culturais } \\
\text { do local e do ambiente de onde vem a força de trabalho. }\end{array}$ \\
\hline Aspectos psicossociais & $\begin{array}{l}\text { Aqui, utiliza-se o modelo da complexidade cognitiva (Harvey, Hunt \& Schro- } \\
\text { der, 1961; Harvey, 1966). Segundo ele, em geral, à medida que as pessoas são } \\
\text { encorajadas a explorar e pensar por si mesmas, e vivenciam uma diversidade } \\
\text { de experiências através da educação, mídia, viagens e etc., se tornam mais } \\
\text { complexas cognitivamente. } \\
\text { - Pessoas cognitivamente "concretas", com menos desenvolvimento, tendem } \\
\text { a ter necessidade de estrutura e ordem, baixa tolerância à ambiguidade e confi- } \\
\text { am em regras e tradições nas suas decisões. Tendem a ver o mundo como } \\
\text { relativamente estático e imutável, não gostam de mudanças. } \\
\text { - Pessoas cognitivamente complexas têm pouca necessidade de estrutura e } \\
\text { ordem, toleram a ambiguidade, tem um sistema de crenças aberto, não são } \\
\text { altamente autoritários e são flexíveis. }\end{array}$ \\
\hline
\end{tabular}

Tabela 4.11 - Fatores relevantes a serem considerados em um subsistema de pessoal (Fonte: HENDRICK; KLEINER, 2008, baseado em PERROW, 1967)

Citando os estudos de campo de Neghandi (1977) em empresas de diferentes países, Hendrick e Kleiner (2008, p.119) lembram que existem cinco tipos de 
ambientes externos que afetam o funcionamento organizacional: o Socioeconômico (grau de estabilidade, a natureza da concorrência e a disponibilidade de materiais e trabalhadores qualificados); a Educação (disponibilidade de instalações e programas, e o nível educacional dos trabalhadores); Político (postura governamental, controle de preços, etc.); o Cultural (estado social e sistema de castas, valores e atitudes em relação ao trabalho, gestão, natureza dos sindicatos); e o Legal (controles legais, restrições e requisitos de conformidade).

Referenciando os estudos de Duncan (1972), Hendrick e Kleiner (2008, p.119) apontam que o ambiente externo é estudado de acordo com duas variáveis importantes: o seu nível de mudança (grau de estabilidade e previsibilidade) e o seu nível de complexidade (o número de componentes externos com os quais a organização lida: agências do governo, concorrentes, fornecedores. Quantos mais componentes, maior a complexidade). Combinadas, essas variáveis definem o grau de incerteza do ambiente:

\begin{tabular}{|c|c|c|c|}
\hline & \multicolumn{2}{|c|}{ Nível de mudança } \\
\hline & & Estável & Dinâmica \\
\hline \multirow[t]{2}{*}{ Nível de complexidade } & Simples & Pouca incerteza & Moderada incerteza \\
\hline & Complexo & Moderada incerteza & Muita incerteza \\
\hline
\end{tabular}

Tabela 4.12 - Matriz do esquema de classificação do nível de incerteza do ambiente externo (Fonte: HENDRICK; KLEINER, 2008)

A partir daí, Burns e Stalker (1961) compararam, através de estudos empíricos em indústrias britânicas e escocesas, que o nível de incerteza, de mudanças e complexidade exigiam diferentes tipos de estruturas organizacionais (Tabela 4.13), voltadas para os tipos orgânicas e mecânicas (HENDRICK; KLEINER, 2008, p. 119).

\begin{tabular}{|c|l|}
\hline Tipo de estrutura & \multicolumn{1}{c|}{ Cenário em que funciona melhor } \\
\hline Mecânica & $\begin{array}{l}\text { Funciona melhor em ambientes estáveis e simples; } \\
\text { Diferenciação vertical e horizontal moderadamente alta; } \\
\text { Formalização e centralização; } \\
\text { Tarefas de rotina, comportamentos programados, resposta lenta às mudanças; } \\
\text { Forte ênfase na estabilidade e controle. }\end{array}$ \\
\hline Orgânica & $\begin{array}{l}\text { Ambientes que precisam de flexibilidade e rápida adaptabilidade; } \\
\text { Comunicação lateral no lugar da vertical; }\end{array}$ \\
& Comunicação baseada em conhecimentos e expertise e não posição e autoridade; \\
& Troca de informações no lugar de diretrizes de superiores; \\
& Definição das funções e tarefas menos rígida; \\
& Baixa diferenciação vertical e formalização; \\
& Tomada de decisão descentralizada; \\
& Alto nível de formação e experiência profissional; \\
\hline
\end{tabular}

Tabela 4.13 - Tipos de estrutura organizacional e os cenários em que funcionam melhor (Fonte: HENDRICK; KLEINER, 2008, baseado em BURNS; STALKER, 1961) 
Outra abordagem organizacional do campo ergonômico é a Ergonomia Participativa (no inglês, PE). Ela foca na participação ativa dos atores envolvidos no processo de trabalho ao implementar procedimentos, mudanças e conhecimento organizacional, objetivando a melhora da performance, do ambiente de trabalho, da cultura da empresa e das atitudes (KLEINER, 2008, p.463). Essa abordagem pode ser adotada em conjunto com o MEAD, por exemplo, pois também é construída de acordo com a perspectiva dos sistemas sociotécnicos.

Brown Jr. (2005), que diz que a participação e as práticas participativas são as metodologias principais para o projeto e análise de sistemas de trabalho. Ao mesmo tempo, Kleiner (2008, p.461) faz referência a Pew (1983) ao lembrar que a perspectiva dos ergonomistas ao projetar sistemas de trabalho começa em entender o papel dos usuários na performance do sistema como um todo. Além disso, deve-se sempre partir do pressuposto que os sistemas existem para servir os usuários. Pew e Mavor (2007) relacionaram algumas questões que conduzem um projeto centrado no ser humano de construção de um sistema:

\begin{tabular}{|l|}
\hline \multicolumn{1}{|c|}{ Questões que conduzem um projeto centrado no ser humano de um sistema } \\
\hline Quem são as partes interessadas (steakholders) do sistema? \\
Como ouvir as vozes de todas as partes interessadas? \\
Como resolver os conflitos entre as necessidades das partes interessadas? \\
Quais são as metas e restrições? \\
Quais padrões sociais e interativos ocorrem no local da prática? \\
Qual é o contexto mais amplo organizacional / sociopolítico no local onde trabalho ocorre? \\
\hline
\end{tabular}
Tabela 4.14 - Questões que conduzem um projeto centrado no ser humano de construção de um sistema (Fonte: baseado em PEW; MAVOR, 2007)

Citando Hendrick e Kleiner (2001), Brown Jr. observa que a ergonomia participativa se dá quando os trabalhadores são envolvidos no processo de análise e projeto ergonômicos. Assim, a PE é encontrada, em algum grau, "em praticamente todos os outros métodos ergonômicos, e suas aplicações no projeto e análise ergonômicos são infinitas" (BROWN JR, 2005, p.81-2, traduzido pelo autor). Pew e Mavor (2007, p.149) lembram que análises, projetos e implementações que desconsiderem as perspectivas dos steakholders podem resultar em problemas funcionais, organizacionais ou econômicos dentro do sistema.

Numa abordagem participativa, o papel do ergonomista pode variar, mas em todos os casos ele será um agente de mudança nos processos que, invariavelmente, necessitarão do envolvimento das equipes de trabalho (BROWN Jr., 2005, 
p.81-3). Na Tabela 4.15 estão descritos os papéis que o ergonomista pode desempenhar em abordagens participativas:

\begin{tabular}{|c|l|}
\hline $\begin{array}{c}\text { Papéis que o ergonomista } \\
\text { pode desempenhar }\end{array}$ & \multicolumn{1}{c|}{ Descrição dos papéis } \\
\hline Treinador & $\begin{array}{l}\text { Os membros de comitês de ergonomia ou grupos de resolução de pro- } \\
\text { blemas devem receber treinamento em trabalho em equipe e habilidades } \\
\text { interpessoais. Gestores podem precisar de instruções sobre como se } \\
\text { relacionar com os trabalhadores que agora podem tomar decisões (Wil- } \\
\text { son e Haines, 1997). }\end{array}$ \\
\hline $\begin{array}{c}\text { Consultor; Recurso } \\
\text { ("Resource Person") }\end{array}$ & $\begin{array}{l}\text { O ergonomista é familiarizado com a tecnologia em uso e disponibiliza } \\
\text { suas habilidades e conhecimentos para ajudar a resolver um problema ou } \\
\text { contribuir para a análise e o projeto de uma intervenção ergonômica. }\end{array}$ \\
\hline Facilitador da mudança & $\begin{array}{l}\text { O facilitador pode ser o "proprietário" de um projeto ou a pessoa que } \\
\text { quer a intervenção; pode ser alguém dentro ou fora da organização. }\end{array}$ \\
\hline
\end{tabular}

Tabela 4.15 - Papéis que o ergonomista pode desempenhar em abordagens participativas (Fonte: BROWN Jr., 2005, traduzido pelo autor)

O principal ganho com a participação dos funcionários numa análise do sistema de trabalho, segundo Hendrick (2005, p.75-2), é que eles conhecem os sintomas dos problemas. Além disso, podem ajudar na escolha da ferramenta de mudança que melhor se encaixe ao seu perfil e contexto.

Os funcionários gostam de se sentir importantes, respeitados e apreciados. As experiências de participação positiva abordam as necessidades sociais e do ego de um funcionário. Processos de gestão organizacional com a participação dos funcionários corporativos na produção, resolução de problemas, projeto ou atividades de compartilhamento de opinião proporcionam benefícios tanto para a organização quanto para o empregado (CARAYON; HOONAKKER; SMITH, 2012, p.537, traduzido pelo autor).

A participação dos atores envolvidos é positiva até em cenários onde a ferramenta de mudança proposta não passa pela preferência dos funcionários:

(...) tendo participado do processo, os funcionários são mais propensos a apoiar as alterações do sistema de trabalho, mesmo que a sua própria abordagem preferida não for a adotada (HENDRICK, 2005, p.75-3, traduzido pelo autor).

A implementação da participação dos steakholders numa organização é dividida por Brown Jr. em três abordagens que se diferenciam no grau em que os quatro pontos-chave de uma organização (Informação sobre o conhecimento dos trabalhadores; Sistema de recompensa/remuneração; Performance organizacional; e Poder de ação e decisão que influenciem práticas e políticas organizacionais) podem ser movidos para o menor nível hierárquico possível (Tabela 4.16). Essa 
divisão lembra bastante a progressão do nível de participação do usuário de Cybis, Betiol e Faust (2007) já abordada neste capítulo. De qualquer forma, ao implementar processos de envolvimento e participação dos trabalhadores, as organizações devem atentar para qual dessas abordagens tem melhor "ajuste" (fit) com o perfil da empresa (BROWN JR, 2005, p.81-2).

\begin{tabular}{|l|l|}
\hline $\begin{array}{c}\text { Nível de participação de } \\
\text { steakholders numa } \\
\text { organização }\end{array}$ & \multicolumn{1}{c|}{ Descrição das abordagens } \\
\hline $\begin{array}{l}\text { Envolvimento Paralalelo } \\
\text { (participação consultiva); }\end{array}$ & $\begin{array}{l}\text { Pede aos trabalhadores para resolverem problemas e produzir ideias } \\
\text { que influenciem a operação de rotina da organização, paralelamente às } \\
\text { atividades normais. Não têm autoridade formal; recompensas diretas } \\
\text { não são dadas; não têm o poder de implementar suas próprias decisões. }\end{array}$ \\
\hline $\begin{array}{l}\text { Envolvimento no Trabalho } \\
\text { (participação substantiva); }\end{array}$ & $\begin{array}{l}\text { Foco em projetar o trabalho, para aumentar a motivação e redesenhar } \\
\text { melhor o projeto e a estação de trabalho. Equipes apresentam um sis- } \\
\text { tema formal de envolvimento; participação direta e alto grau de contro- } \\
\text { le. Não é só uma atividade especial, como na abordagem de sugestão } \\
\text { paralela. É a forma como a organização conduz o seu negócio. }\end{array}$ \\
\hline Alto Envolvimento & $\begin{array}{l}\text { Estrutura a organização para que os níveis mais baixos tenham um } \\
\text { senso de envolvimento, não apenas na eficácia, mas no desempenho } \\
\text { total de toda a organização. Move informações, conhecimento, recom- } \\
\text { pensas e poder para o nível organizacional mais baixo. Os trabalhado- } \\
\text { res se preocupam com o desempenho organizacional porque sabem } \\
\text { sobre isso, são capazes de influenciá-lo, são recompensados por fazê-lo } \\
\text { e possuem o conhecimento e habilidades para contribuírem. Requer } \\
\text { mudanças consistentes e contínuas. }\end{array}$ \\
\hline
\end{tabular}

Tabela 4.16 - Tipos de abordagem na participação de steakholders numa organização.

(Fonte: BROWN Jr., 2005)

O conceito de fit é muito importante no design organizacional. A teoria dos sistemas sociotécnicos sustenta que nenhuma parte de uma organização deve ser alterada sem uma consciência e consideração de seu papel em todo o sistema. Os principais elementos que precisam se adequar são as pessoas, os processos de informação, a tecnologia, o sistema de recompensas e a estrutura organizacional (LAWLER, 1992 apud BROWN Jr., 2005, p. 81-2, traduzido pelo autor).

Assim como no Design, as metodologias ergonômicas organizacionais enxergam a importância da análise e estudo contínuo dos elementos e interações presentes nos sistemas de trabalho.

Profissionais e pesquisadores da ODAM há muito reconhecem a importância do processo de melhoria contínua: o projeto dos sistemas de trabalho deve ser um processo contínuo. Por exemplo, ao revisar os princípios do design do sistema sociotécnico (SST), Clegg (2000) enfatiza que o processo de projetar SST se estende ao longo do tempo. Novas necessidades de negócios e funcionários podem surgir, exigindo que o projeto do sistema de trabalho seja reavaliado e adaptado (CARAYON; HOONAKKER; SMITH, 2012, p.548, traduzido pelo autor). 
Pew e Mavor (2007, p.149) lembram que é preciso sempre atentar para a Organização e o ambiente em que ela se encontra, mesmo após o sistema estar projetado. Citando Carayon (2006), os autores sublinham que os sistemas sociotécnicos necessitam de adaptação, melhorias e participação dos empregados e clientes de forma contínua (Tabela 4.17).

\begin{tabular}{|c|c|}
\hline $\begin{array}{l}\text { Príncipios para adaptação } \\
\text { e melhoria de um sistema }\end{array}$ & Descrição dos princípios \\
\hline Participação & $\begin{array}{l}\text { Participação ativa dos steakholders nas atividades de projeto do sistema } \\
\text { (Ex: Ergonomia participativa). }\end{array}$ \\
\hline Interações & $\begin{array}{l}\text { Interação contínua entre os múltiplos sistemas de trabalho e entre os } \\
\text { sistemas e o ambiente. }\end{array}$ \\
\hline Design (projeto) & O sistema de trabalho deve ser continuamente desenhado e redesenhado. \\
\hline Adaptação & $\begin{array}{l}\text { O sistema deve ser adaptado para prover saúde, produtividade e sustenta- } \\
\text { bilidade no longo prazo. }\end{array}$ \\
\hline Aprendizagem & $\begin{array}{l}\text { Apoio à aprendizagem individual e organizacional (definição, análise e } \\
\text { modelagem de problemas de forma colaborativa). }\end{array}$ \\
\hline $\begin{array}{l}\text { Construção de sentido } \\
\text { (sense making) }\end{array}$ & $\begin{array}{l}\text { Todas as mudanças que ocorrem - e os impactos que possam causar - } \\
\text { devem fazer sentido e serem entendidas. }\end{array}$ \\
\hline
\end{tabular}

Desta forma, considerando todas as metodologias e práticas expostas, podemos resumir a visão da ergonomia organizacional na Tabela 4.18:

\footnotetext{
Organizações enquanto sistemas - as organizações são sistemas abertos, formados por vários sistemas internos interligados e que estão contidos e cercados por outros sistemas externos. Analisa-se todos esses sistemas e as interações entre eles, na busca pelo equilíbrio entre essas relações.

Os sistemas de trabalho são vistos pela ótica sociotécnica - deve-se focar na relação entre os subsistemas de Pessoal, Tecnológico, de Ambiente relevante e Organizacional.

Foco nas questões humanas - o ser humano é o centro do processo; a análise do sistema de trabalho mede, identifica e resolve incompatibilidades de interface entre as capacidades humanas, o projeto de trabalho e as tecnologias e ferramentas utilizadas. A busca pela melhora na produtividade e eficácia se baseia na motivação, na qualidade de vida profissional e na segurança. Busca atender as expectativas e necessidades das pessoas em uma organização.

O ambiente tem importância fundamental - as características, contingências e influência dos ambientes externos e internos da organização devem ser cuidadosamente observadas e consideradas.

Análise é feita através de métodos científicos testados e validados - as metodologias aplicadas na ergonomia organizacional - e os modelos que ela utiliza - foram formalmente validados e testados empiricamente em várias organizações.

Participação e colaboração dos atores envolvidos no processo - envolver os steakholders é fundamental na busca por soluções organizacionais. O ergonomista pode atuar como um facilitador dessa participação, como um consultor para a organização ou ainda como um treinador.

O processo de análise macroergonômica pode ser cíclico, iterativo e flexível - adaptado para a realidade atual, para a complexidade dos problemas e dos sistemas que aborda.

Tabela 4.18 - Características das metodologias ergonômicas aplicáveis no campo organizacional (Fonte: o autor, com base na pesquisa realizada)
}

Como visto, o Design propõe uma abordagem com foco no ser humano, com metodologias colaborativas que valorizam o conhecimento tácito e a interpretação da subjetividade humana. Ao mesmo tempo, a Ergonomia, apesar de também ser centrada no ser humano, dá muita importância a fatores contingenciais do 
ambiente que cerca os atores envolvidos nos processos, através da abordagem da Teoria dos Sistemas. A seguir, a pesquisa propõe reunir características dessas duas correntes num "pensamento" de ergodesign organizacional, por entender que a soma das suas semelhanças e diferenças talvez sejam exatamente o que o cenário da gestão da produção multidisciplinar de material didático em EAD precisa.

\section{2. O Ergodesign Organizacional: uma visão humanista, participativa, sistêmica e contextual}

Ao se relacionar as metodologias do Design e da Ergonomia que são aplicáveis no campo organizacional e nos sistemas de trabalho, talvez possa-se chegar a denominadores comuns que definam uma visão organizacional do Ergodesign. Ela envolveria metodologias que incluam não só a participação os atores envolvidos no processo, mas também a análise dos ambientes ao seu redor. Uma visão que pense tanto as questões subjetivas do ser humano quanto as questões objetivas do trabalho e da organização. Um pensamento organizacional que busque colocar todas essas questões em equilíbrio, proporcionando a melhor experiência possível para todos os envolvidos.

Fazer essa relação talvez ajude a explicar melhor a aplicação dos conceitos do Design e da Ergonomia no âmbito organizacional. Além disso, caracterizaria que não se está falando apenas de um conjunto de técnicas e ferramentas, mas sim de uma abordagem como um todo, uma visão diferenciada de como as pessoas e os ambientes de trabalho devem pensados na sua relação com as organizações.

Para Yap et al. (1997), ergodesign é um conceito novo. Significa a fusão dos focos teóricos e práticos das duas disciplinas: Ergonomia e Design. À medida que os sistemas se tornam mais complexos, torna-se cada vez mais difícil estabelecer as diferenças entre as duas disciplinas. Ao contrário dos enfoques mais conhecidos (...) que buscam garantir uma ótima compatibilidade ergonômica dos componentes do sistema com as metas globais do sistema, ergodesign garante a otimização do desenvolvimento das tecnologias da ergonomia e do design no processo criativo (MORAES, 2013, p.3).

Ainda segundo Moraes (2013), o ergodesign possui um enfoque macroergonômico e criativo. Desta forma, busca focar nos "atributos humanos e do sistema simultaneamente com a conceituação e desenvolvimento do design". Essa pos- 
tura tornaria o ergodesign uma ferramenta importante na implementação e desenvolvimento de produtos, equipamentos e sistemas.

Citando Wilcox (1998), Moraes lembra que com o aumento da complexidade dos problemas de design, as metodologias tiveram que se modificar e se tornarem mais vastas. Com isso, a integração de ergonomistas e designers no desenvolvimento de produtos e sistemas aumentou (MORAES, 2013, p.6).

Colocando esse conceito na perspectiva levantada nesse capítulo, esta pesquisa se questiona se não seria possível agrupar as interseções e particularidades dessas metodologias num "Ergodesign Organizacional" que buscaria unir as visões complementares do Design e da Ergonomia. O Ergodesign Organizacional seria a fusão de conceitos de metodologias como Design Thinking e Macroergonomia, por exemplo, numa abordagem a ser aplicada em organizações e ambiente de trabalho.

Reunindo as várias vertentes do Design e da Ergonomia listados neste capítulo, podemos começar a traçar essa visão organizacional do ergodesign, agrupando-as visualmente (Figura 4.4):

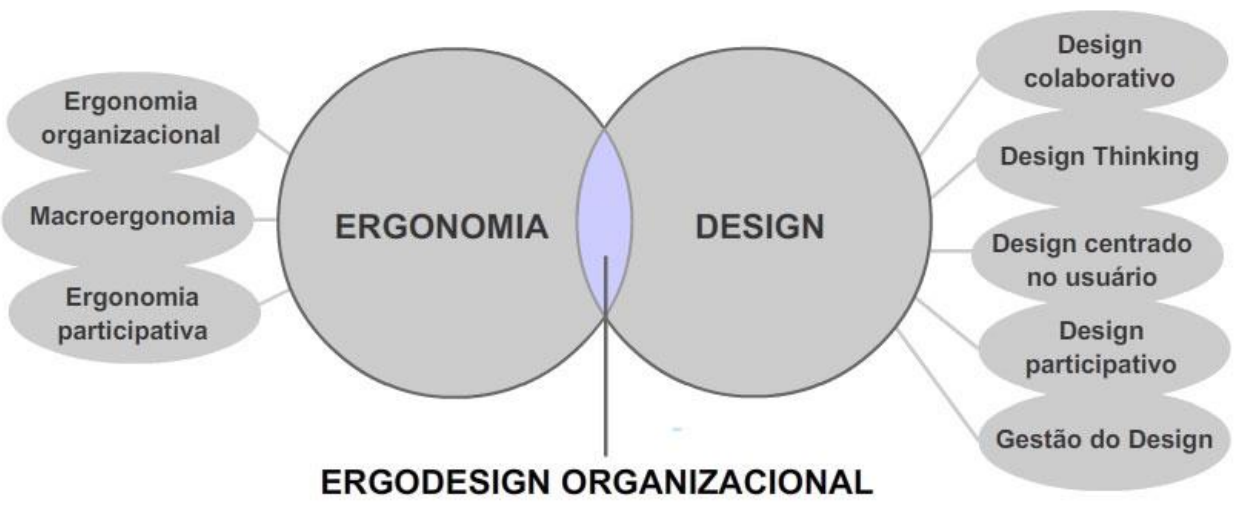

Figura 4.4 - Metodologias do Design e da Ergonomia aplicáveis na gestão de equipes de trabalho (Fonte: o autor, com base na pesquisa realizada)

Considerando autores como Buchanan (2005), Silva (2012) e Hendrick e Kleiner (2002), entre outros citados neste capítulo, pode-se apontar quais seriam as vantagens e o diferencial da abordagem organizacional do ergodesign. Ela seria centrada no ser humano (busca conhecer os envolvidos, focar na qualidade da experiência que a organização oferece a eles); colaborativa (a vivência cotidiana e o conhecimento tácito dos envolvidos é excelente fonte de resolução de problemas, ideias e melhorias); e sociotécnica e contextual (considera o impacto de fatores 
como tipo de tarefa, políticas da empresa, tecnologias envolvidas e questões culturais internas e externas). Mas já que a proposta desta parte da pesquisa é reunir visões particulares e comuns, e não apenas um conjunto de métodos e técnicas, na Figura 4.5 são agrupadas as características do Design e da Ergonomia organizacionais, independentemente da (s) metodologia (s) onde sejam mais citadas e consideradas.

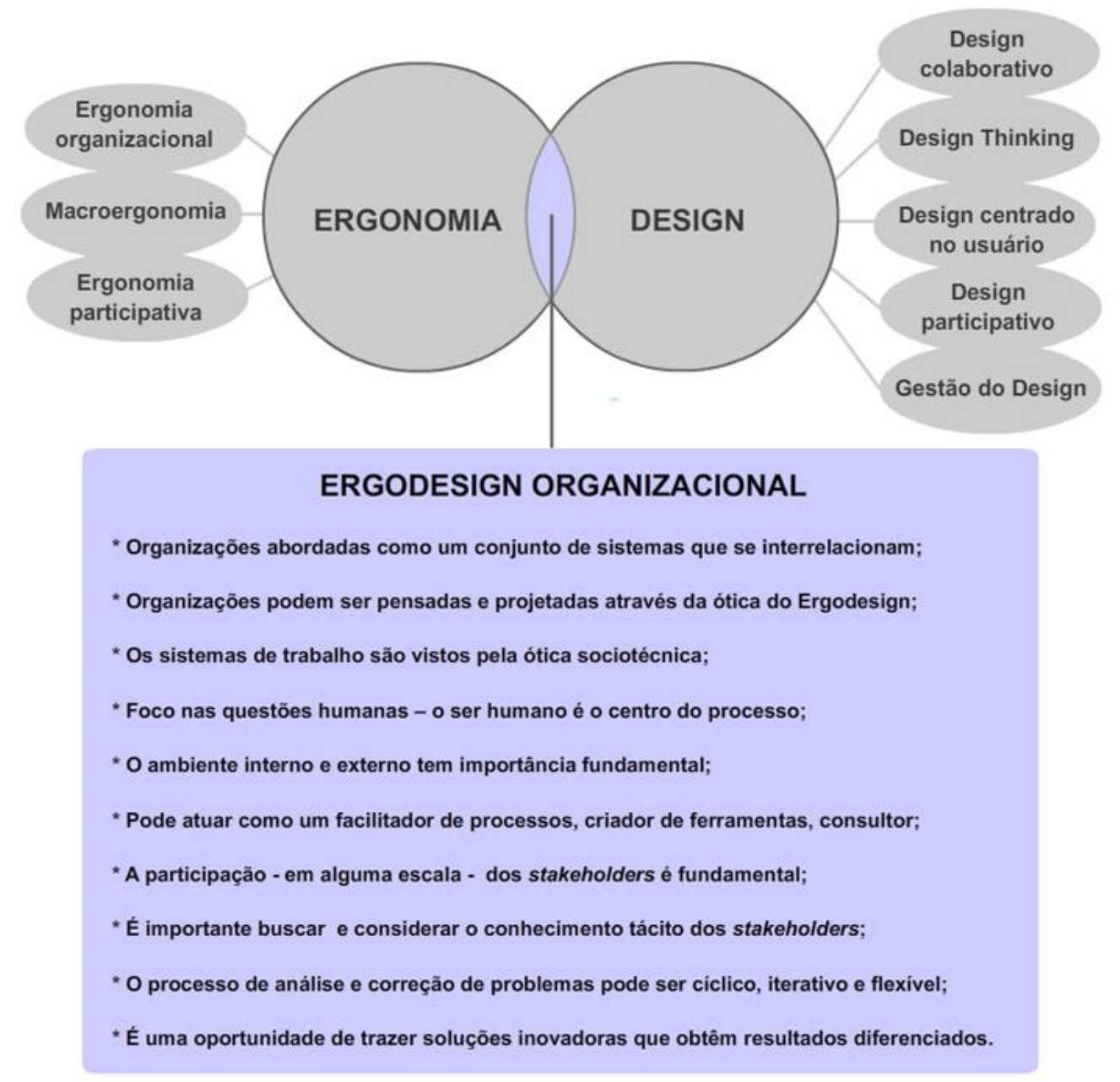

Figura 4.5 - Características básicas da abordagem do Ergodesign no campo organizacional (Fonte: o autor, com base na pesquisa realizada)

Por limitações próprias de uma dissertação de mestrado, futuras pesquisas acadêmicas poderão se aprofundar melhor no conceito do Ergodesign Organizacional e nas inter-relações entre as diferentes metodologias aqui explicitadas. Outro desdobramento possível é comparar a união do Design e da Ergonomia com duas visões antagônicas do estudo da Administração: as metodologias subjetivistas, interpretativas; e as metodologias objetivistas, funcionais. Autores como Astley e Van de Ven (2007) e Caldas e Fachin (2005) abordam essa dicotomia e a necessi- 
dade da Administração em chegar a um meio-termo entre elas. $\mathrm{O}$ ergodesign poderia ser uma resposta interessante, pois agrupa criatividade, conhecimento tácito, contingências ambientais e correlação sistemática. Desta forma, coloca o ser humano e sua subjetividade no centro do processo, mas não se esquece das necessidades práticas e funcionais.

A seguir, o conceito do ergodesign será aplicado no recorte pesquisado nesta dissertação. Por que ele pode ser uma opção interessante para a resolução de problemas no campo multidisciplinar da EAD?

\section{3. \\ O Ergodesign Organizacional aplicado na produção de material didá- tico em EAD}

Como vimos no Capítulo 2, a produção de material didático para EAD é uma atividade complexa, onde o conhecimento de cada membro da equipe e a criatividade na adaptação dos materiais são fundamentais. É uma atividade profissional ainda recente, com muitas incertezas e em constante evolução. Além disso, se depara com várias demandas externas como leis, busca crescente por cursos e vagas, questões pedagógicas, mudanças tecnológicas e necessidade de diálogo entre equipes multidisciplinares.

Com base em tudo visto neste capítulo, esta pesquisa acredita que a abordagem do Design e da Ergonomia podem servir, no cenário da EAD, para o encontro de novas e melhores soluções organizacionais. Pois, se o ser humano precisa ser abordado e ouvido, ao mesmo tempo as questões ambientais, as demandas externas e as inter-relações sistemáticas ao redor do usuário também precisam ser consideradas.

A multidisciplinaridade da equipe de produção influi nas questões subjetivas de relacionamento entre os profissionais e nas negociações políticas cotidianas com a organização. Ao se contextualizar, no capítulo 3, as diferenças entre os sistemas fordista e toyotista, pôde-se perceber que a participação dos funcionários e a abordagem da atividade profissional, neste campo, deveriam se aproximar dos preceitos da produção mais flexível. O perfil especializado dos funcionários, a codependência multidisciplinar e as especificidades das tarefas não permitem um ambiente de produção mecânico, com funcionários isolados e sem espaço para opinião e diálogo. Por isso, os profissionais envolvidos precisam ser conhecidos, 
entendidos e receber da organização os insumos e incentivo para produzirem e se relacionarem de forma melhor. Boltanski e Chiapello $(2009$, p.38) lembram que a motivação material não é suficiente, mesmo para os assalariados, para provocar o empenho e aguçar o entusiasmo na realização das tarefas. O salário se constitui num motivo para se permanecer no trabalho, mas não para se esforçar. Aí, entrariam a busca pelo conhecimento tácito, pelo pensamento dos envolvidos, pelos sentimentos com relação ao trabalho e a organização. Esses fatores seriam abordados pela visão humanística do Design.

Já questões inescapáveis para o funcionamento da equipe, como a legislação educacional, a corrida tecnológica, as opções políticas, as necessidades organizacionais e a economia seriam abordadas pela ótica sociotécnica e sistêmica da Macroergonomia.

Novas tecnologias oferecem novas capacidades, e estas geralmente geram novas expectativas, papéis e formas de fazer coisas que nem sempre foram antecipadas (Woods e Dekker, 2000). As complexidades não antecipadas podem surgir através do aumento da interconectividade e interdependência do sistema, que criam novas fontes de carga de trabalho, desafios para a resolução de problemas e requisitos de coordenação (PEW; MAVOR, 2007, p. 26, traduzido pelo autor).

Assim, uma abordagem de Ergodesign Organizacional questionaria: os seres humanos envolvidos estão no centro do processo? A organização conhece e escuta essas pessoas? Elas participam das decisões que afetam seu trabalho? As políticas de gestão e centralização de decisões são as mais indicadas para o perfil altamente especializado dos profissionais? A forma de produção adotada é a que funcionaria melhor para aqueles profissionais e cenário? As especificidades de suas tarefas são levadas em conta no projeto do seu sistema de trabalho? As demandas ambientais que impactam no trabalho e nos sistemas têm sua importância reconhecida? Soluções organizacionais já existentes funcionam em uma atividade tão nova e específica, num cenário de tantas mudanças?

Adaptando o modelo de sistema de trabalho de Smith e Carayon-Sainfort (1989) para o contexto multidisciplinar da EAD, pode-se explicitar como os elementos ao redor dos profissionais da área podem ser abordados pelo Ergodesign Organizacional (Figura 4.6). 


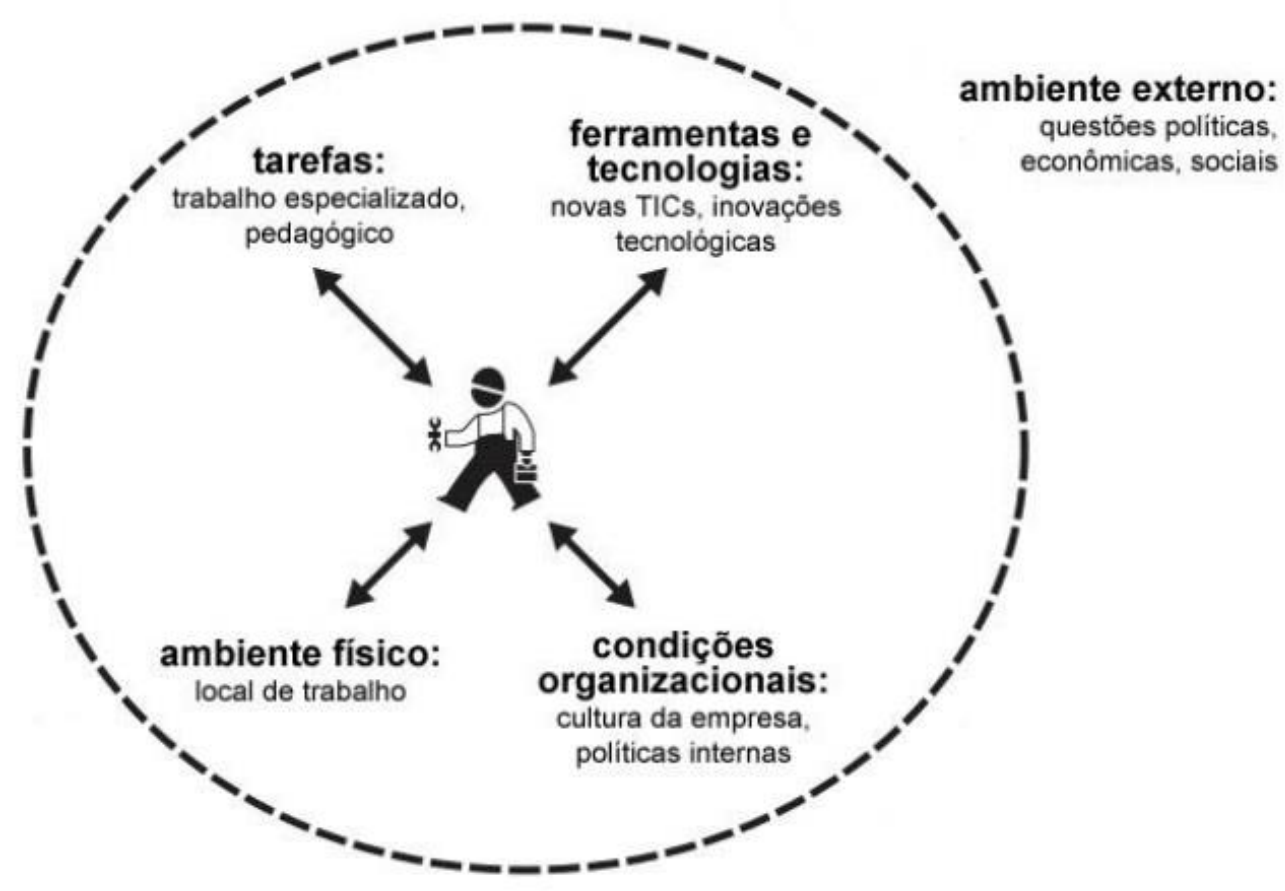

Figura 4.6 - Modelo de sistema de trabalho adaptado para a produção multidisciplinar de material para a EAD (Fonte: o autor, adaptado de SMITH; CARAYON-SAINFORT, 1989)

Boland Jr. E Collopy (2004, p.4) nos lembram que a atitude tradicional de decisão pode ser a maneira mais eficiente e efetiva de abordar a resolução de problemas numa situação claramente definida e estável, quando as alternativas viáveis são bem conhecidas. Mas, quando essas condições não se mantêm, como no cenário atual da EAD, é necessária uma "atitude de design".

Da mesma forma, no campo macroergonômico, Watson et al. (2009, p. 1042) afirmam que apesar da Educação ser um sistema complexo de trabalho, foi pouco explorada pelos métodos e teorias da Macroergonomia. Segundo os autores, o foco da Ergonomia no campo educacional ainda se concentra nas questões biomecânicas.

Assim, resumindo o levantamento teórico feito nos capítulos 2, 3 e 4, pôdese observar que a EAD possui uma série de demandas e características contextuais e externas às IES (legislação, desenvolvimento tecnológico, questões socioculturais) - abordadas no capítulo 2. Ao mesmo tempo, devem ser observadas questões internas e mais voltadas ao trato com os steakholders detalhadas no capítulo 3: modo de produção adotado, políticas da organização, gestão dos funcionários, perfil de chefia. Neste capítulo 4, procurou-se mostrar que a reunião do humanismo do Design com a visão mais sistemática e contextual da Ergonomia talvez 
possam trazer o equilibro necessário entre as questões subjetivas e tácitas dos seres humanos e as questões mercadológicas, pragmáticas e contextuais que caracterizam a gestão da EAD multidisciplinar. Pode-se ter educação e material didático de qualidade, se a ponte entre o conteudista e o aluno é negligenciada? Se as pessoas que produzem o material não são ouvidas? Se as políticas de gestão e produção não se enquadram nas características e demandas das pessoas, das tarefas e do contexto interno e externo?

Levando isso em conta, não poderia a Educação a Distância se beneficiar de uma visão como a apontada por Brown (2009), baseada na inovação e aplicada na gestão, com foco em organizações que precisam se adaptar à novas circunstâncias? É esta questão que se tentará responder no próximo capítulo, quando será realizada uma pesquisa de campo numa equipe de produção de material para EAD. A abordagem prática será baseada nos preceitos organizacionais do ergodesign e as ferramentas escolhidas e aplicadas estarão contidas no escopo das metodologias aqui descritas. 


\section{5 \\ A produção multidisciplinar de material didático na Funda- ção Cecierj: um estudo de caso}

Nesta parte da dissertação, a base teórica e contextual levantada nos capítulos anteriores serve como subsídio para um estudo de caso numa instituição que possua produção de material didático de graduação a distância. Abordar a realidade de trabalho dessas equipes multidisciplinares é uma oportunidade de avaliar a aplicação dos métodos, propostas e ferramentas de Ergodesign no cenário organizacional da Educação a Distância. Através do estudo de caso, se tentará relacionar o trabalho de produção de material didático de EAD com os parâmetros pedagógicos e organizacionais levantados, respectivamente, nos Capítulos 2 e 3. Para isso, a proposta da dissertação foi colher e analisar os resultados obtidos no campo e, sob a visão dos conceitos teóricos levantados, traçar uma proposta de mudança processual e de cultura de trabalho para a equipe multidisciplinar estudada.

Neste capítulo, são listados os métodos e técnicas utilizados pela dissertação no estudo de caso e o delineamento da pesquisa. Também serão apresentadas as razões e a contextualização das escolhas metodológicas e os resultados encontrados na etapa de entrevista com os alguns profissionais da equipe.

\section{1.}

\section{A opção pelo estudo de caso}

Baseando-se nos temas abordados nos capítulos anteriores, não seria possível testar a aplicabilidade dos conceitos organizacionais do Ergodesign longe do ambiente onde a produção do material didático para EAD efetivamente ocorre. Como visto no Capítulo 4, a contextualização das interações entre os profissionais envolvidos e entre os subsistemas sociotécnicos é fundamental para a aferição e análise organizacional de um sistema de trabalho.

Para a obtenção de resultados mais fidedignos, esta pesquisa procurou analisar o sistema de trabalho ao natural. Nesse sentido, uma pesquisa de campo é fundamental, pois permite observar os fatos sociais em seu contexto, sem alterações 
impostas pelo pesquisador (FACHIN, 2003). Optou-se pelo estudo de caso, pois ele é considerado o melhor procedimento para a investigação de um fenômeno contemporâneo dentro de seu contexto efetivo (YIN, 2001). Gil (2002, p.54) define o estudo de caso como uma modalidade de pesquisa onde se pode conhecer, de forma profunda e exaustiva, um ou poucos objetos. Gil (2002) e Yin (2001) afirmam que o estudo de caso permite a exploração de situações indefinidas e a descrição do contexto ao redor do objeto investigado. Essas características são importantes para esta pesquisa, pois a coleta de dados das entrevistas, além da escolha da subsequente metodologia aplicada, precisava ser subsidiada pelas características contextuais encontradas pelo pesquisador em campo. Segundo Yin (2001), o estudo de caso é também uma estratégia muito utilizada em estudos organizacionais e gerenciais, além de permitir lidar com uma gama maior de evidências, como documentos, entrevistas e observações - duas características presentes nesta pesquisa.

\section{2. \\ Delineamento metodológico}

Segundo Gil (2002, p.43) o delineamento da pesquisa é o planejamento da mesma, de forma ampla, e deve organizar não só os seus passos, mas também a previsão de análise e de coleta de dados. Durante a etapa de delineamento, considera-se o ambiente, as variáveis e os procedimentos para a obtenção dos dados. Seguindo os procedimentos de Marconi e Lakatos (2003, p.186) para as fases de uma pesquisa de campo, primeiramente foi realizada um levantamento bibliográfico sobre os temas abordados, para avaliação do seu Estado da Arte e para referenciar a abordagem prática. Posteriormente, houve a definição das técnicas de coleta de dados e, também, do perfil da amostra necessário para a obtenção dos resultados. Por último, estabeleceram-se as técnicas de registro e de análise dos dados. Na Tabela 5.1 são delineadas as etapas desta pesquisa e seus objetivos.

\begin{tabular}{|l|l|}
\hline \multicolumn{1}{|c|}{ Etapas da pesquisa } & \multicolumn{1}{c|}{ Objetivos } \\
\hline 1 - Pesquisa bibliográfica & $\begin{array}{l}\text { Construção de contexto histórico, levantamento do Estado da Arte de } \\
\text { conceitos abordados e embasamento para a realização da pesquisa. }\end{array}$ \\
\hline $\begin{array}{l}\text { 2 - Escolha da unidade de análi- } \\
\text { se e do local da pesquisa }\end{array}$ & $\begin{array}{l}\text { Realizar o estudo de caso em um local que reflita as necessidades do } \\
\text { problema da pesquisa. }\end{array}$ \\
\hline $\begin{array}{l}\text { 3 - Identificação dos processos, } \\
\text { atores envolvidos e do contexto } \\
\text { de trabalho }\end{array}$ & $\begin{array}{l}\text { Observação e pesquisa do ambiente estudado, para entender as re- } \\
\text { gras, costumes e convenções que regem o grupo. Com esses dados, } \\
\text { subsidiar as perguntas da etapa seguinte da pesquisa. }\end{array}$ \\
\hline
\end{tabular}




\begin{tabular}{|l|l|}
\hline $\begin{array}{l}4 \text { - Entrevistas com os profissi- } \\
\text { onais envolvidos e análise do } \\
\text { conteúdo das respostas }\end{array}$ & $\begin{array}{l}\text { Obtenção de dados qualitativos e quantitativos sobre o cotidiano de } \\
\text { trabalho, relações interpessoais e os principais problemas e dificulda- } \\
\text { des que essas pessoas encontrar na sua atividade. }\end{array}$ \\
\hline $\begin{array}{l}5 \text { - Validação de propostas de } \\
\text { melhora no sistema de trabalho, } \\
\text { baseadas na participação dos } \\
\text { usuários }\end{array}$ & $\begin{array}{l}\text { Baseada na análise de conteúdo das entrevistas e no contexto encon- } \\
\text { trado pelo pesquisador, serão escolhidos métodos e técnicas do De- } \\
\text { sign e/ou da Ergonomia que melhor se adequem ao perfil e cenário } \\
\text { encontrados no campo. Estes, serão utilizados para embasar e validar } \\
\text { as propostas surgidas através das entrevistas e do material teórico } \\
\text { levantado pelo autor. }\end{array}$ \\
\hline $\begin{array}{l}\text { 6-Apresentação de sugestões } \\
\text { de mudanças e melhorias para o } \\
\text { sistema estudado }\end{array}$ & $\begin{array}{l}\text { Após a aplicação das metodologias e análise dos resultados, a pesqui- } \\
\text { sa procurará atingir o objetivo principal desta dissertação: "Elaborar, } \\
\text { colaborativamente com os atores envolvidos, propostas de gestão e } \\
\text { de aperfeiçoamento de processos de produção de material didático da } \\
\text { graduação EAD da Fundação Cecierj". }\end{array}$ \\
\hline
\end{tabular}

Tabela 5.1 - Delineamento das etapas do estudo de caso (Fonte: o autor)

\section{3. Pesquisa bibliográfica}

A pesquisa bibliográfica tem como finalidade subsidiar a produção, coleção, armazenamento, (re)produção e comunicação das informações coletadas para a realização de uma pesquisa (FACHIN, 2003, p.125).

O levantamento bibliográfico desta dissertação foi realizado de forma assistemática, e focou especialmente nas áreas de EAD, Design e Ergonomia, passando também por temas como sistemas de trabalho, Gestão, Cultura Organizacional e gestão de pessoas. Também foram pesquisadas as características dos métodos e técnicas do Design e da Ergonomia a serem aplicados no contexto cotidiano da equipe multidisciplinar estudada.

Para a seleção dos textos, livros e periódicos, usou-se o seguinte critério: obras de referência e material pesquisado para construção de contexto histórico não tiveram limitação de data de publicação. Obras sobre temas mais atuais (tecnologia, por exemplo), especialmente no campo da Educação a Distância, foram limitadas ao ano de publicação de 2000. Escolheu-se esta data pois, aproximadamente, é quando começa o crescimento exponencial da EAD no Brasil e o surgimento de inovações tecnológicas que mudaram o paradigma da Educação. As principais fontes de material foram a Biblioteca da PUC Rio, o Portal CAPES, os sítios eletrônicos Google Scholar e Academia.edu, além de textos acadêmicos e leituras realizadas nas disciplinas cursadas. 


\section{4. Escolha da unidade de análise e do local da pesquisa}

A escolha da unidade de análise é um componente fundamental em um projeto de pesquisa, pois define o que é um "caso". As unidades de análise escolhidas definem as preposições de um estudo e delimitam a pesquisa em um escopo exequível (YIN, 2001).

Em sua acepção clássica, a unidade-caso refere-se a um indivíduo num contexto definido. (...) O conceito de caso, no entanto, ampliou-se, a ponto de poder ser entendido como uma família ou qualquer outro grupo social um pequeno grupo, uma organização, um conjunto de relações, um papel social, um processo social, uma comunidade, uma nação ou mesmo toda uma cultura (GIL, 2002, p.138).

Nesta dissertação, o recorte foi feito procurando uma equipe multidisciplinar de produção de material didático, em uma instituição de educação majoritariamente a distância. O processo de EAD tem outros atores fundamentais, como os tutores, mas o tempo disponível para a finalização de um mestrado não permitiria a sua inclusão no estudo. Além disso, a dinâmica de trabalho desses profissionais é mais individual do que multidisciplinar, e os parâmetros seriam diferentes da abordagem aos responsáveis pelo material didático. Assim, a unidade de análise do estudo foi a equipe de produção de material didático da Fundação Cecierj, responsável pelo Consórcio Cederj. Esse local foi escolhido por se adequar ao recorte da pesquisa: oferece todas as disciplinas de graduação a distância e produz seu próprio material. Essas características trazem o contexto necessário para a pesquisa: os cursos exigem processos e arranjos organizacionais mais complexos; a IES deve observar mais exigências governamentais; é necessária a formação de uma equipe multidisciplinar própria; e as inovações tecnológicas impactam nas decisões e na produção do conteúdo multimídia e nas formas de comunicação com os alunos.

Além disso, o autor faz parte da equipe que produz o material didático do Consórcio, tendo acesso aos processos e atores envolvidos. Isso trouxe mais "abertura" da instituição a ser pesquisada e mais oportunidades de abordagem aos profissionais - facilitando, assim, a observação de situações cotidianas e a elaboração coletiva de propostas de melhorias. A seguir, será detalhado o local escolhido para este estudo de caso: a Fundação Cecierj. 


\subsection{1.}

\section{Fundação Cecierj: características e cenário}

A Fundação Cecierj é uma autarquia fluminense, ligada à Secretaria de Estado de Ciência, Tecnologia e Desenvolvimento Social. Suas origens vêm da antiga CECIGUA (Centro de Ciências da Guanabara), um dos seis centros de ciência criados nas principais capitais do Brasil (São Paulo, Rio de Janeiro, Belo Horizonte, Porto Alegre, Salvador e Recife) nos anos de 1960. Segundo Valla e Ferreira (2007), o CECIGUA produziu ideias que influenciaram as disciplinas escolares de Ciências e Biologia, através de iniciativas curriculares inovadoras.

No início do século XXI, refletindo as atribuições advindas do Consórcio Cederj, o Centro de Ciências do Rio de Janeiro passa e se chamar Fundação Cecierj (Centro de Ciências e Educação Superior a Distância do Estado do Rio de Janeiro):

O Cederj é administrado pela Fundação Cecierj, criada pela Lei Complementar estadual n. 103/2002. A referida Lei transformou o Centro de Ciências do Estado do Rio de Janeiro, autarquia com personalidade jurídica de direito público, na Fundação Centro de Ciências e Educação Superior a Distância do Estado do Rio de Janeiro - Fundação Cecierj, pessoa jurídica de direito público, sem fins lucrativos, vinculada à Secretaria de Estado de Ciência e Tecnologia e integrada à Administração Estadual indireta (FIRMINO; VIEIRA, 2013, p.263).

Segundo a Lei Complementar citada acima, o objetivo social da Fundação é "oferecer educação superior gratuita e de qualidade, na modalidade à distância", além de realizar divulgação científica e formação continuada de professores dos ensinos fundamental, médio e superior. Com isso, promoveria a expansão e interiorização do ensino gratuito no Estado, através de “cursos de extensão, graduação e pós-graduação, atividades curriculares e extracurriculares, presenciais ou à distância” (RIO DE JANEIRO, 2002).

Atualmente, o Cecierj mantém atividades como Caravana da Ciência, PréVestibular Social, cursos de extensão e Ensino de Jovens e Adultos. A Fundação administra ainda o Museu Ciência e Vida, no município de Duque de Caxias. Porém, sua principal atividade, no que tange recursos humanos e financeiros, é a administração do Consórcio Cederj, que será abordado a seguir. 


\subsection{2. \\ Consórcio Cederj: educação superior a distância pública e gratuita para o Estado do Rio de Janeiro}

O Cederj (Centro de Educação Superior a Distância do Estado do Rio de Janeiro) é um programa de EAD superior à distância, formado pelo consórcio de sete instituições públicas do Rio de Janeiro (CEFET, UENF, UERJ, UFF, UFRJ, UFRRJ e UNIRIO), e administrado pela Fundação Cecierj desde o seu início, no ano de 2000.

Para a criação do Consórcio, foi assinado um termo de cooperação técnica entre o Governo do estado do Rio de Janeiro, através da Secretaria de Ciência e Tecnologia, a Uenf, Uerj, UFRJ, UFRRJ e a Unirio. Como seria preciso um ente para administrar a organização, é instituída então uma fundação para fazê-lo, que é a Fundação Cecierj (...) (FIRMINO; VIEIRA, 2013, p.266)

O consorciamento de instituições públicas de ensino foi uma estratégia adotada para vencer adversidades da EAD, como falta de pessoal qualificado e de financiamento específico, além de dificuldades estruturais (FIMINO; VIEIRA, 2013). O foco do Cederj são os moradores do interior, que vivem longe das sedes e campi das universidades públicas. Para isso, o Consórcio conta com 32 polos presenciais em 31 municípios (Figura 5.1), equipados com bibliotecas, laboratórios, computadores e salas. Nos polos, os alunos podem realizar, além da tutoria presencial (opcional), os momentos obrigatórios de comparecimento, como provas e aulas laboratoriais.

Atualmente, o Cederj possui cerca de 45 mil alunos de graduação, divididos em quinze cursos: Administração, Administração Pública, Engenharia de Produção; Licenciaturas em: Ciências Biológicas, Física, História, Letras, Matemática, Pedagogia, Química, Turismo, Geografia; e formação de tecnólogos em Sistemas de Computação, Segurança Pública e Turismo. 


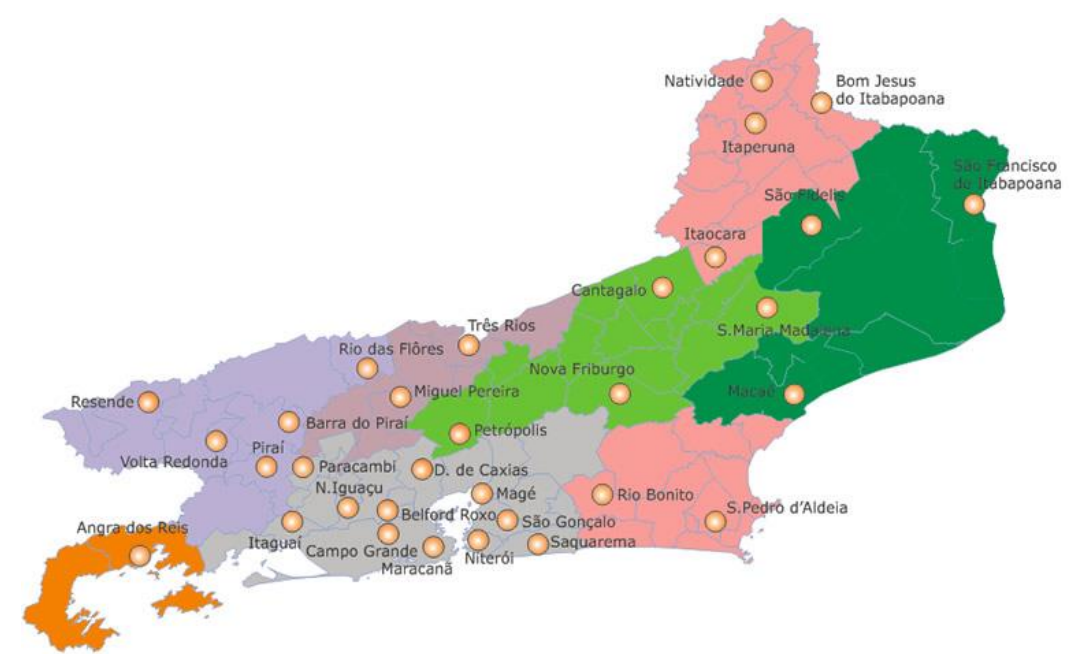

Figura 5.1 - Localização dos polos presenciais de EAD do Consórcio Cederj (Fonte: sítio eletrônico da Fundação Cecierj)

Segundo o Consórcio, sua metodologia educacional se apoia em cinco aspectos, listados na Tabela 5.2:

\begin{tabular}{|l|l|}
\hline $\begin{array}{l}\text { Aspectos metodológicos do } \\
\text { Cederj }\end{array}$ & \multicolumn{1}{c|}{ Características } \\
\hline Material didático próprio & $\begin{array}{l}\text { - Material especialmente preparado para Educação a Distância, incluindo } \\
\text { impressos, videoaulas e recursos multimeios; }\end{array}$ \\
\hline $\begin{array}{l}\text { Sistema de apoio à aprendi- } \\
\text { zagem }\end{array}$ & $\begin{array}{l}\text { - Tutoria presencial, disponibilizada para os alunos dos períodos iniciais, } \\
\text { através de um encontro semanal de duas horas por disciplina no Polo regi- } \\
\text { onal a que o aluno está vinculado; } \\
\text { - Tutoria a distância, alocada nas Universidades, acessível através da plata- } \\
\text { forma CEDERJ e de telefone gratuito, para todas as disciplinas; }\end{array}$ \\
\hline $\begin{array}{l}\text { Processo de avaliação pre- } \\
\text { sencial }\end{array}$ & $\begin{array}{l}\text { - Provas são realizadas nos Polos Regionais, e são similares àquelas utili- } \\
\text { zadas para avaliar os alunos nos cursos presenciais das Universidades; }\end{array}$ \\
\hline $\begin{array}{l}\text { Sistema de Universidade } \\
\text { virtual }\end{array}$ & $\begin{array}{l}\text { - Plataforma com ambiente virtual de aprendizagem e ferramentas que } \\
\text { garantem interatividade; }\end{array}$ \\
\hline $\begin{array}{l}\text { Laboratórios didáticos e de } \\
\text { apoio nos polos }\end{array}$ & $\begin{array}{l}\text { - Laboratórios didáticos de Biologia, Computação, Física e Química nos } \\
\text { polos que oferecem esses cursos; } \\
\text { - Polos com estrutura para atender o aluno: laboratórios de informática com } \\
\text { Internet, biblioteca e salas de estudo com pessoal técnico-administrativo, } \\
\text { além dos tutores presenciais. }\end{array}$ \\
\hline
\end{tabular}

Tabela 5.2 - Aspectos metodológicos dos cursos oferecidos pelo Consórcio Cederj (Fonte: Fundação Cecierj)

Apesar do vestibular único, cada consorciada tem seu próprio quadro de vagas e mantém particularidades, como sistemas de cotas. O aluno aprovado no vestibular é matriculado regularmente como aluno da IES responsável pelo curso escolhido.

No que se refere ao conteúdo acadêmico, as disciplinas e aulas são fornecidas e coordenadas pela instituição responsável por cada curso. Assim, por exemplo, em um curso de Licenciatura em Pedagogia oferecido pela UERJ, a mesma indicará o coordenador do curso, o currículo, os conteudistas e os professores res- 
ponsáveis pelas salas de aula virtuais. $\mathrm{O}$ aluno, ao fim do curso, receberá um diploma da UERJ, idêntico ao dos estudantes presenciais. A parte administrativa do consórcio, a produção de material didático, a seleção de tutores, o pagamento de bolsas para tutores e docentes, os sistemas acadêmicos e a organização do vestibular, entre outras atribuições, são feitos pelo Cecierj, através de recursos estaduais e verbas federais da Universidade Aberta do Brasil (UAB). A divisão de atribuições no consórcio é feita entre Estado, Municípios e Governo Federal, e está descrita na Tabela 5.3:

\begin{tabular}{|l|l|}
\hline \multicolumn{1}{|c|}{ Ente Federativo } & \multicolumn{1}{c|}{ Funções no consórcio } \\
\hline Governo do Estado do Rio de Janeiro & - Participação das Instituições estaduais (ex: UERJ); \\
& - Apoio financeiro, especialmente de custeio; \\
& - Gestão via Fundação Cecierj: administração, pagamento de \\
& bolsas aos docentes e aos tutores; equipamento para operacio- \\
& nalização dos polos regionais, montagem do material didático, \\
& organização do vestibular. \\
\hline Municípios fluminenses & - Cessão de espaço para alocação dos polos presenciais. \\
\hline Governo Federal & - Participação das Instituições federais (ex: UFRJ); \\
& - Apoio financeiro através da UAB. \\
\hline
\end{tabular}

Tabela 5.3 - Atribuições dos entes no Consórcio Cederj (Fonte: o autor, com base na pesquisa realizada; e FIRMINO; VIEIRA, 2013)

\subsection{3.}

\section{A crise econômica do Estado do Rio de Janeiro a partir de 2015}

Um fator importante que deve ser contextualizado nesta pesquisa é o cenário de crise econômica enfrentado pelo Governo do Estado do Rio de Janeiro, a partir de 2015. Esta questão foi amplamente coberta pelos veículos de imprensa e ficou explicitada como decreto de Estado de Calamidade Pública, realizado pela administração fluminense em 17 de junho de 2016. Segundo matéria publicada no sítio eletrônico do jornal $O$ Globo, a causa principal desse decreto foi a incapacidade financeira do Estado honrar seus compromissos, especialmente os referentes aos Jogos Olímpicos de 2016 (O GLOBO, 2017).

No que tange esta pesquisa, no decorrer da realização das entrevistas, os salários dos servidores do Cecierj começaram a ser parcelados. Posteriormente, já na fase da análise de conteúdo, não havia certeza das datas de pagamento e os atrasos foram constantes. Em 2017, o Governo chegou a dever três meses de salário aos trabalhadores.

Esta questão influenciou o dia-a-dia do funcionamento do Cecierj. A produção das aulas diminuiu, muitos funcionários passaram a trabalhar de casa e a Fun- 
dação precisou mudar de sede (transferindo toda sua estrutura física) duas vezes em um ano. $\mathrm{O}$ autor desta dissertação e sua orientadora cogitaram a possibilidade de realizar a pesquisa em outro local. Porém, o resultado das entrevistas com os funcionários se mostrava muito rico, os participantes enxergavam a crise como uma questão temporária e as respostas, de modo geral, não refletiam esse problema especificamente. Além do mais, se a visão organizacional do Design e da Ergonomia podem ser adaptáveis a qualquer situação contextual, a questão específica da crise do Estado do Rio de Janeiro não poderia ser um impeditivo para a realização da pesquisa.

Assim, o estudo de caso foi mantido. Posteriormente, o agravamento da crise econômica, que acarretou em ausência de funcionários, pedidos de licença e problemas financeiros, influenciou na escolha dos métodos e técnicas aplicadas na fase de validação participativa das propostas de melhoria. Mas, mesmo assim, a participação dos respondentes nesse segundo momento foi acima da expectativa e gerou bastante material para a apresentação das sugestões de melhoria. A escolha pela metodologia desse segundo momento participativo será aprofundada no próximo capítulo.

\section{5 . Identificação dos processos, atores envolvidos e do contexto de tra- balho}

Esta parte do processo se realizou com o consentimento da diretoria do setor de material didático. A princípio, houve uma liberação informal, após a proposta da pesquisa ser explicada. Posteriormente, um dos diretores assinou um documento formal, oficializando a realização da pesquisa. Não houve, em momento algum, interferência ou negativa por parte da Fundação CECIERJ a qualquer etapa do processo. A pesquisa se preocupou, pelo seu lado, em abordar os profissionais em momentos que não interferissem nas suas tarefas.

Primeiramente, fez-se um levantamento sobre as características contextuais e organizacionais da equipe de material didático, através da experiência do autor enquanto funcionário da equipe. Segundo Gil (2002, p.130), a fase exploratória de uma pesquisa de campo é uma etapa onde se pode realizar uma investigação informal, onde se procura obter "entendimento dos fatores que exercem influência na situação que constitui o objeto de pesquisa”. Citando Katz (1974), o autor lista 
alguns itens que podem auxiliar a investigação nesta etapa da pesquisa e que foram consideradas nesta dissertação (Tabela 5.4), especialmente na fase de redação da pauta das entrevistas com os profissionais. Gil (2002, p. 140 e 141) lembra ainda que o estudo de caso se utiliza de dados provenientes da convergência de mais de uma técnica, e o uso de procedimentos diversos garante a qualidade dos resultados encontrados. Isso garantiria "validade ao estudo, evitando que ele fique subordinado à subjetividade do pesquisador".

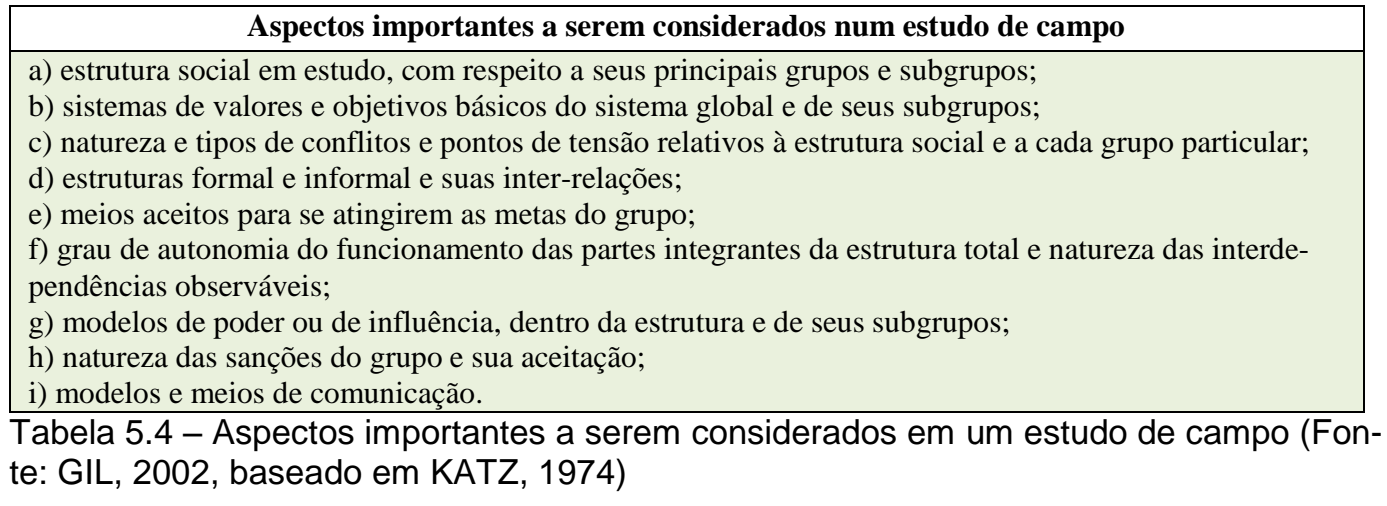

Desta forma, a opção pelo estudo de caso também seria uma maneira de depurar qualquer viés causado pelo fato deste autor ser membro da equipe de produção do material. Este estudo teve dois momentos colaborativos (entrevistas e construção das propostas de mudança) também como uma maneira de passar pela visão dos demais funcionários os dados vindos da observação exploratória.

Foram catalogadas questões como: perfil das subequipes e número de profissionais de cada uma; metodologia de trabalho utilizada; organograma do setor; arranjos organizacionais da instituição; e características do sistema de trabalho (questões tecnológicas e políticas de gestão, por exemplo). Esse material foi dividido em dois tópicos: atores envolvidos no processo e processos e fluxogramas do setor. A partir da compilação desses dados, foi feita a pauta da etapa seguinte, uma entrevista estruturada com funcionários do setor de material didático da Fundação Cecierj.

\subsection{1. Atores envolvidos no processo}

No Cederj, as instituições consorciadas definem currículos, coordenadores, conteudistas e professores responsáveis pelas disciplinas e pelas salas de aula vir- 
tuais. Os profissionais que desenvolvem essas funções não têm vínculo com a Fundação, sendo apenas remunerados pelo seu trabalho através de bolsas.

No caso específico do material didático, apesar dos autores do conteúdo serem externos à Fundação, a equipe de produção é formada por funcionários vinculados ao Cecierj, em sua grande maioria servidores estatutários selecionados em dois concursos, datados de 2005 e 2013.

No total, sessenta e três pessoas trabalham no Departamento de Material Didático da Fundação, sendo dois diretores e o autor desta dissertação, que não foram abordados por esta pesquisa. Os demais profissionais se dividiam em nove subequipes, detalhadas na Tabela 5.5:

\begin{tabular}{|l|c|l|}
\hline Subequipes de produção & Profissionais & \multicolumn{1}{c|}{ Funções básicas } \\
\hline Animação para $w e b$ & 2 & Desenvolver animações para as aulas \\
\hline Desenho instrucional & 24 & Adaptar o conteúdo para as diferentes mídias da EAD \\
\hline Design gráfico & 10 & Produção do material impresso e conversão para e-books \\
\hline Ilustração & 5 & Ilustraçães e infografia para as aulas \\
\hline Produção gráfica & 2 & Cuidar de questões gráficas e de impressão dos livros \\
\hline Revisão & 8 & Revisar o conteúdo antes de ser adaptado para livros e web \\
\hline $\begin{array}{l}\text { Suporte aos professores } \\
\text { (plataforma Moodle) }\end{array}$ & 2 & $\begin{array}{l}\text { Auxiliar os professores na autoria e na publicação de material } \\
\text { na plataforma Moodle }\end{array}$ \\
\hline Vídeo & 2 & Filmagem de vídeo-aulas e de eventos da Fundação \\
\hline Web design & 5 & $\begin{array}{l}\text { Produção de ferramentas e adaptação do Moodle para as salas } \\
\text { de aula na } w e b\end{array}$ \\
\hline
\end{tabular}

Tabela 5.5 - Subequipes de produção de material didático do Cederj, seu número de profissionais e suas funções básicas (Fonte: o autor, com base na pesquisa realizada)

\subsection{2.}

\section{Levantamento dos processos e fluxogramas de produção do setor}

Até 2015, o departamento de material didático do Cederj era dividido em três grandes equipes independentes, que contavam com diretores próprios: Desenho Instrucional (DI) - responsável pela a adaptação das aulas originais para a EAD; Material Impresso - que englobava toda a produção dos livros didáticos, produção gráfica e a revisão textual e Mídias Digitais - onde trabalhavam os web designers, a equipe de vídeo e os animadores. A produção, como um todo, era linear e as equipes eram bastante isoladas entre $\mathrm{si}$ - inclusive fisicamente. $\mathrm{O}$ contato dos conteudistas era maior com os DIs e com os designers gráficos, e a equipe web ficava responsável, na maioria das vezes, por apenas adaptar o conteúdo impresso para a internet, sem participar do planejamento inicial das disciplinas. Essa forma de produção pode ser vista no fluxograma apresentado na Figura 5.2. 
O pedido de afastamento do Diretor de Mídias Digitais, em 2015, coincidiu com a vontade da Fundação de integrar a produção do material e repensar o processo como um todo.

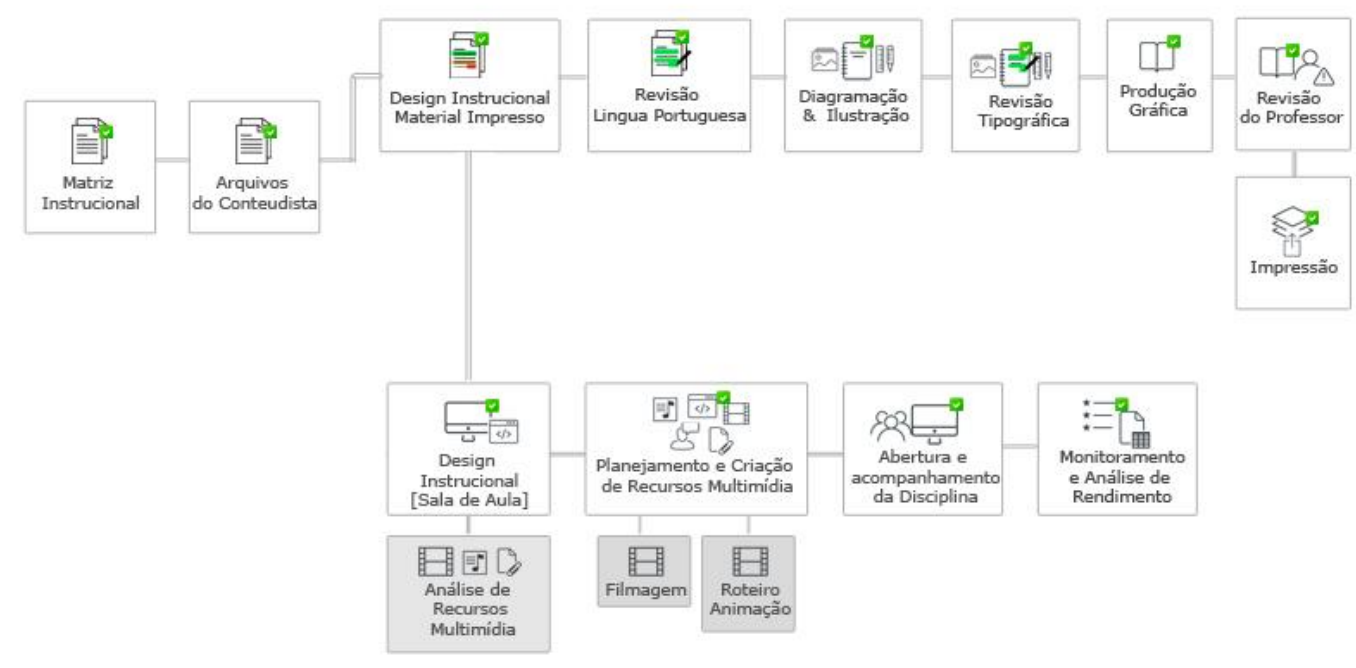

Figura 5.2 - Fluxograma do processo linear de produção de material didático do Cederj, adotado até 2015 (Fonte: Fundação Cecierj)

Foram realizadas reuniões entre os profissionais, suas chefias e o presidente da Fundação, onde se debateu questões e problemas do setor e a integração das equipes. Foram levantados alguns problemas, sendo os mais recorrentes: a falta de conhecimento das tarefas e processos entre as equipes e a distância e falta de participação do conteudista externo na produção do material.

Começou-se, então, um processo de mudança: os três setores foram reunidos como um Departamento de Material Didático, tocado pelos dois diretores remanescentes. A Fundação também propôs uma nova forma de produção do material: um processo integrado, onde profissionais de todas as subequipes se juntariam aos conteudistas e participariam, desde o início, do planejamento dos materiais. Esse novo fluxograma é apresentado na Figura 5.3: 


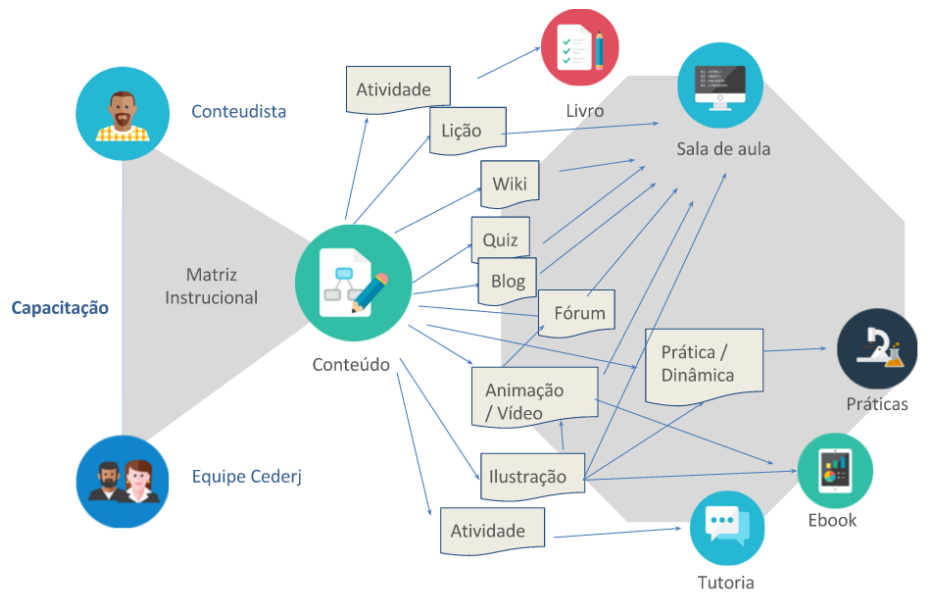

Figura 5.3 - Fluxograma do processo integrado de produção de material didático do Cederj, adotado a partir de 2015 (Fonte: Fundação Cecierj)

As questões contextuais e de fluxo de trabalho levantadas nas reuniões da Fundação foram abordadas pela pesquisa nas entrevistas estruturadas. Também se levou em conta as mudanças propostas pela direção após essas reuniões: a junção dos três setores e o novo modelo de produção do material. A pauta da entrevista e os objetivos de cada pergunta serão detalhados a seguir.

\section{6. Entrevistas estruturadas com os profissionais da equipe multidisci- plinar}

A entrevista é uma técnica de coleta de dados que envolve duas pessoas numa situação "face a face", onde uma delas formula questões e a outra responde, e é a forma de interrogação que apresenta maior flexibilidade (GIL, 2003). Segundo Marconi e Lakatos (2003), entrevistas podem possuir limitações como influência da presença do entrevistador, indisposição do entrevistado em dar informações e receio dos respondentes em ter sua identidade revelada. Mesmo assim, optou-se por essa forma de inquirição, pois dúvidas ou discordâncias sobre perguntas e respostas podem ser abordadas de imediato pelo entrevistador, trazendo informações mais precisas. Além disso, a compreensão das questões é maior, afinal o entrevistador pode repetir, reformular ou esclarecer perguntas (MARCONI; LAKATOS, 2003). Também se levou em conta a necessidade de que os respondentes expressassem maior quantidade possível de informações. É importante lembrar que todas as questões desta etapa eram abertas. Desta forma, o uso de um questionário, por exemplo, poderia ser cansativo para os participantes e resultar 
em respostas curtas ou incompletas que não adicionariam material suficiente à pesquisa. A presença do entrevistador poderia ajudar a diminuir essa possibilidade, através do reforço da importância e do sentido das perguntas e através do incentivo à participação do respondente.

\subsection{1.}

\section{Organização da pauta da entrevista}

Optou-se por uma entrevista menos extensa, dado que era abordado um tema politicamente sensível: a avaliação do trabalho dos respondentes. Procurou-se abordar apenas os pontos realmente essenciais levantados na observação do autor. Outras questões mais específicas, caso surgissem, poderiam ser apresentadas na fase posterior da pesquisa.

As perguntas foram organizadas do seguinte modo: as questões com respostas factuais viriam em primeiro lugar, seguidas de questões mais amplas, sobre dificuldades e estrutura de forma geral. Em sequência, viriam questões mais específicas sobre o fluxo de trabalho e organização do setor. Essa opção foi feita com base no entendimento de Gil (2002, p.115), de que perguntas sobre fatos têm obtenção mais fácil de respostas, ao contrário das "perguntas referentes a sentimentos, crenças, padrões de ação, bem como a razões conscientes que os determinam". Dessa forma, questões que se referiam a sentimentos, percepções e, principalmente, a decisões de chefia (como junção dos setores e mudanças no modelo de produção), foram posicionadas na metade final da pauta - mas não no seu fim. Com isso, procurou-se abordar esses assuntos em um momento onde o respondente já estivesse mais acostumado com a dinâmica, mas ainda não cansado ou com pressa para acabar de responder. Por esse motivo, a entrevista foi do tipo estruturada, onde as perguntas foram feitas na mesma ordem para todos os participantes, fora alguma eventual necessidade de esclarecimento ou questionamento de uma das partes. A montagem da pauta (Tabela 5.6) se baseou, também, nas etapas propostas por Courage e Baxter (2005).

\begin{tabular}{|l|l|l|}
\hline \multicolumn{1}{|c|}{ Etapa } & \multicolumn{1}{|c|}{ Pergunta } & \multicolumn{1}{c|}{ Objetivo da pergunta } \\
\hline Perguntas iniciais & $\begin{array}{l}\text { 1. Qual sua área de atuação e seu } \\
\text { subsetor no Cecierj? }\end{array}$ & $\begin{array}{l}\text { Identificar o cargo do participante e a } \\
\text { função que desempenha; }\end{array}$ \\
\cline { 2 - 3 } $\begin{array}{l}\text { Objetivo: Identificar } \\
\text { o cargo e o nível de } \\
\text { experiência dos parti- } \\
\text { cipantes. }\end{array}$ & $\begin{array}{l}\text { 2. Hánto tempo você atua na área } \\
\text { de EAD? }\end{array}$ & $\begin{array}{l}\text { Quantificar a experiência profissional do } \\
\text { respondente e seu nível de conhecimento } \\
\text { acerca da Fundação; }\end{array}$ \\
\hline
\end{tabular}




\begin{tabular}{|c|c|c|}
\hline \multirow{8}{*}{$\begin{array}{l}\text { Corpo principal da } \\
\text { entrevista } \\
\text { Objetivos: Levanta- } \\
\text { mento das questões e } \\
\text { problemas cotidianos } \\
\text { do trabalho dos entre- } \\
\text { vistados; Buscar } \\
\text { opiniões e sugestões } \\
\text { dos respondentes } \\
\text { sobre o cotidiano de } \\
\text { trabalho do setor de } \\
\text { material didático. }\end{array}$} & $\begin{array}{l}\text { 3. Fale um pouco sobre a estrutura } \\
\text { oferecida para você trabalhar. }\end{array}$ & $\begin{array}{l}\text { Pela visão macroergonômica, a estrutura } \\
\text { de trabalho é um elemento fundamental } \\
\text { nos sistemas sociotécnicos. Objetiva } \\
\text { colher informações sobre problemas } \\
\text { estruturais observados; }\end{array}$ \\
\hline & $\begin{array}{l}\text { 4. Você tem alguma dificuldade } \\
\text { cotidiana na realização do seu traba- } \\
\text { lho no Cecierj? }\end{array}$ & $\begin{array}{l}\text { Levantamento das dificuldades mais } \\
\text { observadas pelos profissionais. Importan- } \\
\text { te para a formulação de melhorias e } \\
\text { correção de problemas; }\end{array}$ \\
\hline & $\begin{array}{l}\text { 5. Quais sugestões você daria para } \\
\text { melhorar o que é produzido no seu } \\
\text { trabalho? }\end{array}$ & $\begin{array}{l}\text { Fomentar um dos objetivos do relatório: } \\
\text { levantar e validar coletivamente suges- } \\
\text { tões de melhoria para o setor e os proces- } \\
\text { sos de trabalho. Esta questão é posicio- } \\
\text { nada aqui para não sofrer influência das } \\
\text { questões específicas ( } 6 \text { a } 10) \text {; }\end{array}$ \\
\hline & $\begin{array}{l}\text { 6. Na realização do seu trabalho, com } \\
\text { qual frequência você tem contato } \\
\text { profissional com pessoas de outras } \\
\text { sub-áreas do seu setor (por exemplo, } \\
\text { DIs, web designers, animadores, } \\
\text { material gráfico, etc.?) }\end{array}$ & $\begin{array}{l}\text { Avaliar se os profissionais sentiam falta } \\
\text { de comunicação e integração entre as } \\
\text { subequipes do material didático - um dos } \\
\text { motivos alegados para a mudança estru- } \\
\text { tural do setor realizada em } 2015 ;\end{array}$ \\
\hline & $\begin{array}{l}\text { 7. O quanto você diria que conhece o } \\
\text { dia-a-dia de trabalho dos profissionais } \\
\text { das outras sub-áreas do seu setor (por } \\
\text { exemplo, DIs, web designers, anima- } \\
\text { dores, DI de impressos, etc.?) }\end{array}$ & $\begin{array}{l}\text { Também avaliar se faltava comunicação } \\
\text { e integração entre as subequipes, e o } \\
\text { quanto os profissionais conhecem do } \\
\text { trabalho e das funções uns dos outros; }\end{array}$ \\
\hline & $\begin{array}{l}\text { 8. O que você acharia de uma propos- } \\
\text { ta de ter mais conhecimento sobre o } \\
\text { funcionamento do setor de produção } \\
\text { de material didático como um todo? }\end{array}$ & $\begin{array}{l}\text { Validar as medidas tomadas pela Funda- } \\
\text { ção para a integração dos subsetores e } \\
\text { aferir se os funcionários sentiam necessi- } \\
\text { dade de que essa questão fosse aprofun- } \\
\text { dada. Esta questão foi colocada neste } \\
\text { ponto da pauta para não influir nas res- } \\
\text { postas anteriores, especialmente nas } \\
\text { questões de } 4 \text { a 7; }\end{array}$ \\
\hline & $\begin{array}{l}\text { 9. Qual sua opinião sobre o novo } \\
\text { modelo de criação de disciplinas, } \\
\text { envolvendo profissionais de todas as } \\
\text { especialidades do setor desde o início, } \\
\text { comparado ao modelo anterior? }\end{array}$ & $\begin{array}{l}\text { Foi proposto um sistema de produção } \\
\text { integrado. Essa pergunta buscava a vali- } \\
\text { dação do mesmo pelos respondentes: o } \\
\text { que funcionava ou não? O que poderia } \\
\text { melhorar? A mudança valia a pena? }\end{array}$ \\
\hline & $\begin{array}{l}\text { 10. Qual sua opinião sobre a trans- } \\
\text { formação dos } 3 \text { antigos setores (DI, } \\
\text { Material Impresso e Mídias digitais) } \\
\text { em um só? }\end{array}$ & $\begin{array}{l}\text { Buscar a opinião dos funcionários sobre a } \\
\text { junção dos três setores. O autor observa- } \\
\text { va opiniões muito variadas sobre o tema, } \\
\text { muitas delas negativas. Os funcionários } \\
\text { achavam a mudança válida? Os proble- } \\
\text { mas foram reduzidos? }\end{array}$ \\
\hline \multirow[t]{2}{*}{$\begin{array}{l}\text { Perguntas finais } \\
\text { Objetivos: Aferir a } \\
\text { opinião dos partici- } \\
\text { pantes sobre a EAD } \\
\text { em geral e comentá- } \\
\text { rios adicionais sobre } \\
\text { os temas abordados }\end{array}$} & 11. Qual sua opinião sobre EAD? & $\begin{array}{l}\text { Um problema relatado pela ABED em } \\
\text { seus censos e na literatura sobre EAD é a } \\
\text { dificuldade de adaptação e o preconceito } \\
\text { em relação à Educação a Distância. Isso } \\
\text { teria interferência no setor do Cecierj? } \\
\text { Esta pergunta foi uma forma indireta de } \\
\text { medir o nível de aceitação e as opiniões } \\
\text { dos funcionários sobre a EAD; }\end{array}$ \\
\hline & 12. Mais algum comentário? & $\begin{array}{l}\text { Espaço para o respondente levantar } \\
\text { questões, sugestões e pontos que possam } \\
\text { ter escapado ao pesquisador, ou reforçar } \\
\text { algum assunto abordado na entrevista. }\end{array}$ \\
\hline
\end{tabular}

Tabela 5.6 - Perguntas da entrevista estruturada e seus objetivos (Fonte: o autor, baseado em COURAGE; BAXTER, 2005) 


\subsection{2. \\ Metodologia da arguição}

Duas das principais preocupações desta pesquisa foram garantir anonimato aos participantes e reduzir ao máximo qualquer desconforto causado pelo fato de responderem sobre seu trabalho. Gil (2002, p.132), citando Katz (1974) reafirma que uma coleta de dados - por ser um processo longo e que requer momentos de contato variados com diferentes pessoas - pode se utilizar de vários procedimentos. Entre eles: fornecer aos participantes as informações obtidas; e preservar a identidade dos respondentes. Neste sentido, foi apresentado um Termo de Consentimento Livre e Esclarecido a todos os entrevistados, onde lhes era garantido: o anonimato de sua identidade e de suas respostas; acesso ao conteúdo da sua entrevista, se assim desejassem; e o direto de suprimir, a qualquer momento, trecho ou totalidade de sua participação na pesquisa. Além disso, explicou-se a importância e os objetivos da pesquisa e o fato de que se tratava de um estudo acadêmico sem vínculo com a Fundação Cecierj. Esse Termo foi lido e assinado pelos participantes, e está disponível, na íntegra, no Apêndice I da dissertação. Outra medida tomada foi a de realizar a entrevista fora do ambiente de trabalho, em locais como cafés ou na residência do profissional. Posteriormente, atendendo aos pedidos de respondentes, e em vista da dificuldade de agendamento das entrevistas (causada pelo atraso de salários e pelo desconforto de alguns profissionais), também foi oferecida a possibilidade de entrevistas remotas, à distância. Elas foram feitas através da ferramenta de áudio do aplicativo WhatsApp, por ser o preferido dos respondentes. Importante destacar que, nesse caso, todas as entrevistas remotas foram realizadas em tempo real, na ordem da pauta e com a presença online do pesquisador. Não houve envio de lista de perguntas para posterior participação ou interrupção da entrevista para que fosse concluída em outro momento. As arguições foram feitas de maneira a reproduzirem a mesma dinâmica da entrevista presencial.

Gil (2002, p.132) lembra que é preciso realizar pré-testes de todos os instrumentos de pesquisa antes de sua efetiva aplicação. Com isso, procura-se: desenvolver os procedimentos; testar vocabulário; e assegurar que as questões efetivamente abordam as variáveis que se quer medir. Assim, foram realizadas duas entrevistas-piloto do tipo remota e uma presencial, para testar a pauta e o modo de 
condução das perguntas. Em ambos os formatos não foram relatados problemas ou observações por parte dos participantes. A obtenção de respostas foi muito rica, principalmente no formato remoto. Com o sucesso dos testes-piloto, manteve-se o formato e a pauta, e os resultados obtidos foram considerados no montante geral das informações levantadas.

Todas as entrevistas - presenciais ou não - tiveram seu áudio gravado e foram transcritas. A pedido da banca examinadora desta dissertação de mestrado - e visando o anonimato dos participantes - a íntegra das transcrições não está disponível nos apêndices deste trabalho, mas podem ser obtidas contatando-se o autor. Posteriormente, foi feita uma análise de conteúdo das respostas, para fomentar a redação de etapa seguinte do estudo de caso.

\subsection{3.}

\section{Seleção da amostra e participação dos funcionários}

Em geral, precisa-se definir uma amostragem dos elementos que compõem o universo estudado, pois não é possível estudá-lo em sua totalidade (GIL, 2002, p.121). No caso desta pesquisa, o tempo mais exíguo de um mestrado e as questões financeiras dos servidores não permitiriam conduzir entrevistas abertas e individuais com mais de cinquenta pessoas. Assim, optou-se por uma amostragem do tipo estratificada, que é definida por Gil (2002) como a "seleção de uma amostra de cada subgrupo da população considerada”. Buscou-se, primeiramente, que a amostragem refletisse a proporção da divisão dos funcionários pelas equipes que compõem o setor. Neste ponto da pesquisa, porém, houve dificuldade em convencer pessoas de algumas subequipes a participar das entrevistas, mesmo fora do trabalho ou a distância. Esse problema se refletiu principalmente nas subequipes de revisão e design gráfico. Curiosamente, duas das que mais registraram participação na fase seguinte da pesquisa. Outro fato relevante aconteceu nas subequipes de vídeo e produção gráfica: ambas possuíam uma profissional em licença maternidade no momento das entrevistas, estando, então, restritas a um servidor cada. Considerando que a participação de ambos seria mais identificável e o anonimato não poderia ser garantido, ambos preferiram não participar. No caso específico dessas subequipes, observou-se que essas ausências não eram tão problemáticas para o levantamento em questão. Por um lado, a produção gráfica é uma função 
essencialmente técnica e isolada - voltada para a impressão dos livros. Já a equipe de vídeo, apesar de alocada no Departamento de Material Didático, presta serviço para toda a Fundação e é bastante isolada (inclusive fisicamente) e independente. Ambas não participam da formatação conceitual das aulas e dos outros materiais. Mesmo assim, seus profissionais foram convidados a participar da etapa da pesquisa que se seguiu às entrevistas. Apesar desses problemas, os resultados obtidos até então já eram muito ricos. Como o material coletado ainda seria submetido a um número maior e mais diverso de profissionais na etapa seguinte, partiu-se para uma estratégia de entrevistar um número suficiente de profissionais disponíveis dentro do tempo possível, mas garantindo que ao menos um representante de cada subequipe fosse contemplado - fora os casos de licença maternidade citados. Fezse, no total, doze entrevistas. Dez delas foram realizadas entre 31 de março e 21 de julho de 2016. As duas últimas foram realizadas em março de 2017. Coincidentemente, seis delas foram presenciais e seis a distância. Apesar das dificuldades, os desenhistas instrucionais - maior equipe do setor - foram os mais abordados, com quatro respondentes. A lista de participantes e seus cargos podem ser vistas na Tabela 5.7.

\begin{tabular}{|l|c|c|}
\hline Subequipe de produção do material & Pessoas na subequipe & Participantes entrevistados \\
\hline Animação para $w e b$ & 2 & 1 \\
\hline Desenho instrucional & 24 & 4 \\
\hline Design gráfico & 10 & 1 \\
\hline Ilustração & 5 & 2 \\
\hline Produção gráfica & 1 (de 2) & - \\
\hline Revisão & 8 & 1 \\
\hline Suporte aos professores (Moodle) & 2 & 1 \\
\hline Vídeo & 1 (de 2) & - \\
\hline Web design & 5 & 2 \\
\hline
\end{tabular}

Tabela 5.7 - Divisão dos participantes das entrevistas, em relação ao cargo ocupado. (Fonte: o autor, com base na pesquisa realizada)

Para garantir maior anonimato aos participantes, daqui por diante eles serão referenciados pela pesquisa através das alcunhas de "Entrevistado 1" a "Entrevistado 12", sem distinção de cargo e gênero. Na Tabela 5.8 são especificadas a lista de respondentes, o tipo de entrevista de cada profissional e o local onde a mesma ocorreu. Por esses dados, pode-se ter uma ideia da dificuldade dos servidores em participar: das sete primeiras entrevistas, seis foram remotas. Das seis entrevistas presenciais, apenas três foram na Fundação Cecierj. 


\begin{tabular}{|l|c|c|}
\hline \multicolumn{1}{|c|}{ Participante } & Tipo de entrevista & Local da entrevista \\
\hline Entrevistado 1 (Piloto 1) & Remota & Residências dos mesmos \\
\hline Entrevistado 2 (Piloto 2) & Remota & Residências dos mesmos \\
\hline Entrevistado 3 (Piloto 3) & Presencial & Fundação Cecierj \\
\hline Entrevistado 4 & Remota & Residências dos mesmos \\
\hline Entrevistado 5 & Remota & Residências dos mesmos \\
\hline Entrevistado 6 & Remota & Residências dos mesmos \\
\hline Entrevistado 7 & Remota & Residências dos mesmos \\
\hline Entrevistado 8 & Presencial & Fundação Cecierj \\
\hline Entrevistado 9 & Presencial & Fundação Cecierj \\
\hline Entrevistado 10 & Presencial & Residência do respondente \\
\hline Entrevistado 11 & Presencial & PUC-Rio \\
\hline Entrevistado 12 & Presencial & Escola do filho do respondente \\
\hline
\end{tabular}

Tabela 5.8 - Lista de respondentes, tipo de entrevista e local de realização (Fonte: 0 autor, com base na pesquisa realizada)

Ainda no que se refere ao perfil dos respondentes, através da questão número 2 da entrevista foi possível levantar o tempo de experiência em EAD dos participantes. É importante notar que pelas características da Fundação - de admitir servidores apenas por concurso - nenhum membro do setor estudado possuía, então, menos de dois anos de experiência com EAD, já que o último concurso havia se realizado em 2013. Metade dos participantes (seis pessoas) possuíam experiência de EAD em outros lugares além do Cederj. Nove dos entrevistados tinham, até então, mais de cinco anos de experiência em EAD, sendo que quatro deles possuíam dez ou mais anos de experiência. Esses dados demonstram que os respondentes tinham vivência na área e experiência, o que poderia facilitar seu entendimento sobre os assuntos abordados.

A seguir, será detalhado o resultado da análise de conteúdo e como esse material foi utilizado para direcionar a etapa seguinte do estudo de caso.

\section{7.}

\section{Análise de conteúdo das entrevistas estruturadas}

Segundo Bardin (2011, p.15), a análise de conteúdo é um conjunto de instrumentos metodológicos que se aplicam a "discursos" (conteúdos e continentes) diversificados. Instrumentos baseados em uma hermenêutica (arte de interpretar os textos sagrados ou misteriosos) controlada: a inferência. Em geral, seus métodos objetivam superar a incerteza (a leitura do pesquisador é efetiva? É compartilhada por outros? É válida e generalizável?) e enriquecer a leitura (o aprofundamento do olhar pode trazer mais produtividade e pertinência? Pode ajudar a com- 
preender filigranas e elementos mais sucintos?). A análise de conteúdo tem uma função heurística: enriquece a tentativa exploratória e aumenta a propensão para a descoberta, além de ser uma técnica que descreve sistematicamente o conteúdo de mensagens (escritas, orais, sonoras), obtendo, dessa forma, indicadores para realização de inferências (BARDIN, 2011, p.35 e 44).

Por essas características, usou-se esta técnica em conjunto com as entrevistas: para avaliar, entre outras coisas, quais as questões mais relevantes, os problemas mais citados, as sugestões de melhoria propostas pelos funcionários abordados.

\subsection{1.}

\section{Pré-análise}

A análise de conteúdo se divide em três fases: pré-análise, exploração do material e interpretação (BARDIN, 2011). Na pré-análise, organizam-se as ideias iniciais colocadas pelo referencial e definem-se os indicadores para a interpretação das informações coletadas. É onde se faz uma leitura geral das entrevistas transcritas e dos documentos relacionados ao tema (BARDIN, 2011). Também ocorrem a leitura flutuante (primeiro contato com os documentos da coleta, que ajuda no nascimento de hipóteses e projeção de teorias, além de um pensamento inicial sobre técnicas a serem utilizadas), a definição do corpus da análise e a formulação dos objetivos e indicadores que serão utilizados para interpretar o material coletado.

Ainda segundo Bardin (2011), a definição do corpus deve seguir alguns critérios, que foram observados por esta pesquisa: exaustividade (consideração de todo o material, não se deixando nada de fora por qualquer razão); representatividade (análise a partir de uma amostra do universo escolhido), homogeneidade (padronização dos documentos) e pertinência (os documentos devem ser adequados ao objetivo pretendido).

Considerando o perfil e os objetivos deste estudo de caso, já relatados neste capítulo, o corpus da análise foram doze entrevistas realizadas com profissionais do setor de material didático da Fundação Cecierj. Assim, as transcrições das mesmas foram organizadas e identificadas, de E1 a E12 (referentes ao entrevistado abordado), formando as unidades de amostragem da análise. 
Para que os resultados e categorias obtidos fossem mais amplos, e considerando que eles iriam fomentar outra etapa da pesquisa, optou-se por uma análise com procedimentos exploratórios, onde se parte da evidenciação das propriedades dos textos para a formulação de hipóteses. Segundo Bardin (2011), esses procedimentos permitem que se apreenda, dos textos, ligações entre as diferentes variáveis, funcionando segundo o processo dedutivo.

Em seguida, passou-se ao processo que Moraes (1999) classifica como unitarização - a releitura cuidadosa do material para a definição do tipo da unidade de análise (também chamada de unidade de registro). No caso desta pesquisa, optou-se pelas unidades temáticas. Bardin (2011, p. 135) afirma que a análise temática busca descobrir "núcleos de sentido", onde sua presença ou frequência de aparição podem ter significado relevante, dentro do objetivo da análise. Além disso, é o formato geralmente adotado para estudar motivações de opiniões, atitudes, valores e crenças. A partir dessa definição, iniciou-se o processo de recorte do conteúdo em unidades adequadas aos objetivos e ao referencial de codificação da pesquisa. Bauer e Gaskell (2015) definem o referencial de codificação como uma forma sistemática de comparação, baseada em uma seleção teórica montada de acordo com os objetivos da pesquisa. Assim, o pesquisador se guia por um conjunto de questões no momento de tratar os materiais e conseguir respostas. Segundo Nunes e Mont'Alvão (2017, p.122) é o referencial de codificação que embasa a interpretação do texto. Para isso, a parte considerada relevante do conteúdo é agrupada em unidades de registro e de contexto. Seguindo este procedimento, os recortes isolados foram lidos e codificados em unidades de registro. Bardin (2011, p.134) diz que as unidades de registro são "a unidade de significação codificada" que "corresponde ao segmento de conteúdo considerado unidade de base, visando a categorização e a contagem frequencial". Na sequência, essas unidades foram agrupadas em unidades de contexto, que Moraes (1999) define como unidades mais amplas, que servem de referência e de limites contextuais às unidades de registro. Como pode se perder parte do significado das unidades de registro no seu processo de isolamento, é necessário o seu agrupamento em unidades contextuais. Ao se considerar o contexto em que o registro está inserido, o seu entendimento é facilitado - e seu significado pode ser mantido de forma mais íntegra. Uma unidade de contexto é capaz de conter várias unidades de registro (MORAES, 1999). Assim, com o referencial de codificação determinado, passou-se à análise de con- 
teúdo propriamente dita: a exploração do material e o tratamento dos resultados e impressões. A pré-análise está resumida na tabela 5.9:

\begin{tabular}{|l|l|}
\hline \multicolumn{2}{|c|}{ Resumo da pré-análise de conteúdo } \\
\hline Objetivos da análise & $\begin{array}{l}\text { Levantamento das questões e problemas cotidianos do traba- } \\
\text { lho dos entrevistados e suas opiniões e sugestões sobre me- } \\
\text { lhorias nas suas condições de trabalho; Aferir a opinião dos } \\
\text { participantes sobre a EAD. }\end{array}$ \\
\hline Corpus & $\begin{array}{l}\text { Entrevistas com doze profissionais do Departamento de } \\
\text { Material Didático da Fundação Cecierj }\end{array}$ \\
\hline Unidade de amostragem & Transcrição das doze entrevistas feitas na Fundação Cecierj \\
\hline Códigos das entrevistas & E1, E2, E3, E4, E5, E6, E7, E8, E9, E10, E11, E12 \\
\hline Unidades de registro & Total: 96 \\
\hline Unidades de contexto & Total: 27 \\
\hline
\end{tabular}

Tabela 5.9 - Resumo da pré-análise de conteúdo das entrevistas (Fonte: o autor, com base na pesquisa realizada)

\subsection{2.}

\section{Análise de conteúdo: exploração do material e resultados}

Definidas as unidades de registro e de contexto, a próxima fase da análise foi o agrupamento das unidades em categorias. Bardin (2011, p.146) lembra que as categorias são classes que reúnem as unidades de registro, de acordo com as suas características comuns. No caso desta pesquisa, os elementos foram agrupados em categorias de acordo com semelhanças semânticas, após a definição das unidades de registro e contexto. Esse procedimento de categorização é chamado por Bardin (2011, p.149) como "acervo", e nele "o sistema de categorias não é fornecido, antes resulta da classificação analógica e progressiva dos elementos". Numa entrevista aberta e ampla como a realizada nesta pesquisa, a categorização é uma forma de condensar as várias questões levantadas, agrupando-as com foco nas suas origens. Facilitando, dessa maneira, a leitura e entendimento do material, além da alimentação de dados para próxima etapa do estudo de caso.

Também se optou por uma exploração de conteúdo qualitativa, apesar das unidades também terem sido contabilizadas. Isso se deu após a leitura do material e a percepção que apenas a quantificação dos elementos não traria o cenário suficiente das questões e comentários dos profissionais. Além disso, o levantamento das sugestões de melhoria dos profissionais era uma questão essencialmente qualitativa, e poderia haver desperdício de material levando-se em conta apenas a quantificação. Segundo Bardin (2011), a análise qualitativa é mais intuitiva e mais adaptável a índices não previstos. Esse foi o caso nesta pesquisa, onde vários registros não abordados na pauta das entrevistas surgiram de forma recorrente nos 
relatos. Ainda segundo a autora, a análise qualitativa permite lançar hipóteses e sugerir relações entre um índice da mensagem e variáveis do locutor (BARDIN, 2011, p.145). Mesmo assim, as unidades de registro também foram contabilizadas, para casos onde a hierarquização por quantidade fosse relevante, e como uma ferramenta de apoio para a análise.

Foram, então, definidas sete categorias no total: (1) Opinião dos profissionais sobre os colegas e sobre a proposta da Fundação; (2) Condições de trabalho; (3) Questões processuais do setor de material didático; (4) Questões gerais da Fundação Cecierj; (5) Visão sobre as mudanças propostas para o setor; (6) Sugestões; e (7) Relação dos profissionais com a EAD. Os títulos foram definidos de acordo com as informações que as categorias reuniam e de acordo com a pauta e os objetivos da entrevista. A seguir, será abordado o tratamento desse material e as características de cada uma das categorias.

\subsubsection{1. \\ Categoria 1 - Opinião dos profissionais sobre os colegas e sobre a proposta da Fundação}

Considerou-se a opinião dos funcionários sobre a proposta da Fundação um tema importante, pois permitiria avaliar se há estranhamento dos profissionais com a EAD (tema abordado no capítulo 2). Já no caso das opiniões sobre os colegas, como a própria Fundação identificou problemas de integração entre as equipes, esse registro seria uma forma de medir se essas questões vinham de deficiências organizacionais ou de problemas de relacionamento entre as pessoas. A Tabela 5.10 traz as unidades de registro e de contexto dessa categoria:

\begin{tabular}{|l|l|}
\hline \multicolumn{2}{|c|}{ Categoria 1 - Opinião dos profissionais sobre os colegas e sobre a proposta da Fundação } \\
\hline \multicolumn{1}{|c|}{ Unidades de contexto } & \multicolumn{1}{c|}{ Unidades de registro (ocorrências) } \\
\hline 1.1. Elogios aos colegas de equipe & $\begin{array}{l}\text { 1.1.1. Equipe de web é muito boa (1) } \\
\text { 1.1.2. Material humano é muito bom (3) } \\
\text { 1.1.4. Mão-de-obra muito especializada (1) }\end{array}$ \\
\hline 1.2. Críticas aos colegas de equipe & 1.2 .1 Servidor público se acomoda com a estabilidade (1) \\
\hline 1.3. Elogios à proposta da Fundação & 1.3.1. Admiram a proposta EAD da Fundação (4) \\
& 1.3.2. Fundação busca qualidade no conteúdo dos cursos (2) \\
\hline
\end{tabular}

Tabela 5.10 - Unidades de registro e de contexto da Categoria 1 da análise de conteúdo

Nesta categoria, identificou-se que, para os entrevistados, a há qualidade no material humano da equipe de material didático, sendo um ponto positivo da 
instituição que ajuda a superar os problemas encontrados. Todas as menções a esse fato foram espontâneas, pois não havia uma pergunta específica sobre essa questão. Outro fato que ajuda a chegar a esta conclusão foi que houve apenas uma menção de crítica aos colegas em todas as doze entrevistas, e, ainda assim, mais voltada ao perfil do funcionalismo público em geral.

(...) o grande diferencial do Cederj é o material humano. (...) são os recursos humanos que estão disponíveis para troca, para a relação, são pessoas altamente competentes, inteligentes, criativas, com enorme potencial. Então, eu creio que esse é o maior diferencial. São pessoas que estão dispostas a fazer um trabalho bacana. Eu penso que esse é o maior valor da instituição (Entrevistado 4).

Outra unidade de registro espontânea foi a admiração pela proposta do

Consórcio Cederj. Vê-se que os funcionários entrevistados enxergam a importância social e educacional da proposta do Consórcio para o interior e para as populações carentes.

(...) funcionando adequadamente e tendo essa preocupação com integridade, que é o que o Consórcio Cederj tem, com certeza, eu acho que é algo maravilhoso. É uma grande oportunidade para o estudante, e é uma grande oportunidade financeira, também, para o Estado, de conseguir levar educação pro estado inteiro (Entrevistado 7).

\subsubsection{2. \\ Categoria 2 - Condições de trabalho}

Aqui, reuniu-se opiniões sobre a estrutura oferecida para os profissionais. Esta questão foi abordada na Pergunta 3, mas também surgiram menções ao longo das outras respostas. Autores como Kleiner (2008) e Smith e Carayon-Sainfort (1989) falam da importância do ambiente físico no desempenho dos profissionais. Esta categoria busca medir se as condições oferecidas pela Fundação interferem no cotidiano do setor. Resultados na Tabela 5.11:

\begin{tabular}{|l|l|}
\hline \multicolumn{2}{|c|}{ Categoria 2 - Condições de trabalho } \\
\hline \multicolumn{1}{|c|}{ Unidades de contexto } & \multicolumn{1}{c|}{ Unidades de registro (ocorrências) } \\
\hline $\begin{array}{l}\text { 2.1. Estrutura física, de trabalho ou } \\
\text { maquinário deficiente }\end{array}$ & $\begin{array}{l}\text { 2.1.1. Estrutura física da Sede é ruim (8) } \\
\end{array}$ \\
& $\begin{array}{l}\text { 2.1.2. Problemas de hardware e software (10) } \\
\text { 2.1.3. Ergonomia ruim (mobiliário) (3) }\end{array}$ \\
\hline 2.2. Elogio às condições de trabalho & $\begin{array}{l}\text { 2.2.1. Hardware e softwares adequados (3) } \\
\text { 2.2.2. Não encontra problemas para trabalhar (1) }\end{array}$ \\
\hline $\begin{array}{l}\text { 2.3. Problemas com a plataforma } M o- \\
\text { odle }\end{array}$ & 2.3 .1 . Acesso à plataforma fica muito lento e dificultado (1) \\
\hline
\end{tabular}


2.4. Dificuldades causadas por limitações técnicas

Tabela 5.11- Unidades de registro e de contexto da Categoria 2 da análise de conteúdo
2.4.1. Não existe um sistema próprio de atendimento aos professores que procuram o suporte (1)

Nesta categoria, destacam-se os problemas com os computadores e/ou os softwares utilizados pelas pessoas. Mesmo assim, foram encontrados, em menor número, relatos de que o equipamento e programas eram adequados. Cabe lembrar que alguns cargos, como os revisores, necessitam apenas de computador e internet, enquanto outros, como animadores, web designers e DIs que trabalham com a plataforma, precisam de máquinas com mais processamento e softwares específicos. Há reclamações de programas desatualizados e computadores lentos.

(...) o equipamento, se fosse de melhor qualidade, facilitaria, porque a gente usa coisas muito pesadas, a gente assiste vídeo, usa a plataforma, a gente às vezes precisa ficar com várias abas abertas, e a lentidão às vezes atrapalha, compromete o nosso trabalho, não rende muito (Entrevistado 6).

As condições físicas ruins do local de trabalho também foram bastante citadas. Problemas de sujeira, elevadores quebrados, ar-condicionado deficiente, falta de água, entre outros. Cabe ressaltar que com a piora da situação econômica do Estado do Rio de Janeiro, houve deterioração de serviços como limpeza e manutenção predial, e isso afetou muito a sede da Fundação Cecierj, localizada num prédio antigo. Outra questão relevante é que, ao longo das entrevistas, a Fundação se mudou para um prédio temporário na Glória de qualidade bem superior. Então, pode ter havido uma diminuição desse tipo de relato nas entrevistas.

(...) eu tenho dificuldade sim, em relação à falta de um bebedouro adequado, às vezes tem falta de água na cozinha e nos banheiros, às vezes falta papel higiênico (...) Não sei se a água ali realmente é limpa, tenho essas preocupações. Com a sujeira também do ambiente, que é tudo muito sujo, tem que estar limpando a minha mesa se não quiser trabalhar na poeira. (...)Além do elevador quebrado, também, agora. O medo também da segurança do prédio. Então, são os fatores que dificultam sim (Entrevistado 5).

\subsubsection{3.}

\section{Categoria 3 - Questões processuais do setor de material didático}

Pew e Mavor (2007) lembram que muitos sistemas falham por negligenciarem ou não atenderem os requisitos dos seus usuários. Abordar as questões processuais é fundamental para uma pesquisa com ênfase contextual, como esta. Para que fos- 
sem abordadas de forma mais focada, optou-se por dividi-las em duas categorias: as questões específicas do setor e as questões da Fundação como um todo. A Tabela 5.12 traz as unidades de registro e de contexto da Categoria 3, os relatos específicos do setor:

\begin{tabular}{|c|c|}
\hline \multicolumn{2}{|c|}{ Categoria 3 - Questões processuais do setor de material didático } \\
\hline Unidades de contexto & Unidades de registro (ocorrências) \\
\hline $\begin{array}{l}\text { 3.1. Dificuldades nos processos entre } \\
\text { subequipes }\end{array}$ & $\begin{array}{l}\text { 3.1.1. Estrutura de processos entre as subequipes é confusa (14) } \\
\text { 3.1.2. Falta um fluxo de trabalho constante (4) } \\
\text { 3.1.3. Centralizacão de processos nos DIs (3) }\end{array}$ \\
\hline $\begin{array}{l}\text { 3.2. Pouca integração com outra(s) } \\
\text { subequipe(s) }\end{array}$ & $\begin{array}{l}\text { 3.2.1. Subequipes ainda estão muito isoladas e se comunicam } \\
\text { pouco ( } 48 \text { ) } \\
\text { 3.2.2. Falta de comunicação em geral (5) }\end{array}$ \\
\hline $\begin{array}{l}\text { 3.3. Pouco conhecimento sobre os } \\
\text { alunos }\end{array}$ & $\begin{array}{l}\text { 3.3.1. Os dados sobre os alunos não são disponibilizados (3) } \\
\text { 3.3.2. Não há pesquisa sobre opinião dos alunos (1) } \\
\text { 3.3.3. Não se sabe o perfil dos alunos (2) } \\
\text { 3.3.4. Não há comunicação com os alunos (1) }\end{array}$ \\
\hline $\begin{array}{l}\text { 3.4. Dificuldade nos processos com } \\
\text { outros setores ou com os conteudistas } \\
\text { externos }\end{array}$ & $\begin{array}{l}\text { 3.4.1. Dificuldade nos processos com outros setores da Funda- } \\
\text { ção (5) } \\
\text { 3.4.2. Demora dos conteudistas externos em responder questões } \\
\text { sobre as aulas (7) } \\
\text { 3.4.3. Distanciamento entre o setor e o conteudista externo (13) }\end{array}$ \\
\hline $\begin{array}{l}\text { 3.5. Integração positiva com outra(s) } \\
\text { subequipe(s) }\end{array}$ & $\begin{array}{l}\text { 3.5.1. Troca de informações e experiência com outras subequi- } \\
\text { pes enriqueceu o trabalho (13) } \\
\text { 3.5.2. Acha que existe integração entre as subequipes (1) }\end{array}$ \\
\hline 3.6. Críticas aos conteudistas externos & $\begin{array}{l}\text { 3.6.1. Professores antigos não aceitam mudanças (1) } \\
\text { 3.6.2. Acadêmicos enxergam os técnicos como inferiores (1) } \\
\text { 3.6.3. Conteudistas às vezes não sabem o que é EAD (1) } \\
\text { 3.6.4. Muitas vezes falta engajamento aos conteudistas (1) }\end{array}$ \\
\hline
\end{tabular}

Apesar das mudanças implementadas pela Fundação Cecierj no sentido de integrar os subsetores, houve um grande número de menções (53) ao fato dos profissionais se relacionarem pouco e não conhecerem o trabalho das outras subequipes. Cabe lembrar que esse tópico foi explorado nas Perguntas 6 e 7 da entrevista. Muitos relatos dão conta de desconhecimento sobre o trabalho cotidiano dos colegas (e dos colegas para o seu trabalho), o que causaria fragmentação e entraves no processo de construção do material. Há relatos de profissionais que acabam realizando, eles mesmos, etapas que deveriam ser compartilhadas com outras equipes.

Nas disciplinas em que eu estou que não são integradas, não estão sendo desenvolvidas nessa modalidade integrada, eu realmente não tenho contato com os demais perfis. O único contato que eu tenho é com o Fluxo, que redireciona a linha de produção, a disciplina, para quem vai revisar, pra quem vai diagramar, mas eu realmente sequer vejo o que foi produzido e nem quando ele é finalizado (Entrevistado 4). 
A falta de integração entre as equipes se relaciona diretamente com outra questão muito citada: dificuldades processuais no trabalho do setor. Essas dificuldades seriam geradas, segundo as entrevistas, por fragmentação e pouca comunicação entre as equipes. Também foi dito que ainda há uma produção muito isolada, fordista, em que cada um executa sua tarefa e passa adiante. Assim, a produção, ao passar de uma equipe para outra, ainda ocorre de forma confusa e não padronizada.

Houve, ainda, depoimentos onde se reclama de ausência de um fluxo de trabalho mais definido, que há demora nas respostas quando se precisa de uma demanda de outra subequipe. Também se relatou que não há respeito aos prazos estipulados nos cronogramas. Como veremos na categoria que trata da Fundação como um todo, há questionamentos sobre a ausência de planejamento na instituição, o que se reflete no trabalho das pessoas. Há várias menções sobre processos que são atropelados por demandas urgentes e inesperadas. Ainda assim, há registros (14) sobre integração positiva com os outros subsetores, quando necessário. Há relatos de que essa experiência melhora o trabalho e de que há boa vontade dos outros profissionais em ajudar em dúvidas e atendimento de demandas. Foi dito que profissionais têm relação boa com os subsetores mais próximos da sua atividade, mas desconhecem outros.

(...) como a gente não têm um fluxo muito bem desenhado, eu acho, ou uma gestão pra esse tipo de coisa, pra encaminhar as demandas, solicitações da gente pro web designer. Ou então o fluxo de produção dos cursos, por que a gente não tem uma linearidade pra poder organizar isso de uma forma que eu entre no curso e eu vou produzir sala de aula, e vou mandando demanda pro web designer e ele me devolve na semana seguinte, é uma coisa demorada... eu acho que seria demorado se a gente fizesse assim, e geralmente a gente não tem tempo. Uma coisa de uma hora pra outra, e é complicado eu chegar pro web designer e falar "olha, eu quero pra daqui a pouco essas vinte imagens" (Entrevistado 6).

Outra questão com muitos registros (25), e que apareceu de forma espontânea, foi a dificuldade processual no que tange os conteudistas externos das Universidades. Os principais problemas apontados foram o distanciamento deles para com o setor, em como, às vezes, é difícil o contato com esses profissionais para refinamento de material já escrito. Outra questão muito apontada foi a demora dos conteudistas em dar respostas ou prosseguimento ao processo de construção do material, após participarem de consultas ou reuniões. Essas 
questões atrapalhariam o fluxo de trabalho, o cronograma e também trariam um desconhecimento do conteudista sobre a capacidade de trabalho de cada equipe.

\subsubsection{4. \\ Categoria 4 - Questões gerais da Fundação Cecierj}

Nesta categoria, agrupou-se as questões de influência no trabalho que passavam pela Fundação como um todo, e não apenas ao setor pesquisado. A Tabela 5.13 traz as suas unidades de registro e de contexto:

\begin{tabular}{|c|c|}
\hline \multicolumn{2}{|c|}{ Categoria 4 - Questões gerais da Fundação Cecierj } \\
\hline Unidades de contexto & Unidades de registro (ocorrências) \\
\hline 4.1. Falta de planejamento & $\begin{array}{l}\text { 4.1.1. Falta de metodologia e fluxo definido de trabalho (11) } \\
\text { 4.1.2. Desorganização de processos/funções (10) } \\
\text { 4.1.3. As demandas chegam de repente, sem aviso e sem planejamen- } \\
\text { to (9) } \\
\text { 4.1.4. Não há planejamento interno da Fundação (8) } \\
\text { 4.1.5. Faltam dados concretos para tomada de decisões (3) } \\
\text { 4.1.6. Retrabalho causado por falta de planejamento (3) } \\
\text { 4.1.7. Não há a tentativa de antecipar problemas/gargalos (1) } \\
\text { 4.1.8. A gestão dos processos é deficiente (1) } \\
\text { 4.1.9. Os prazos exigidos não correspondem ao tempo de preparação } \\
\text { do trabalho (1) }\end{array}$ \\
\hline $\begin{array}{l}\text { 4.2. Sentimento de subutiliza- } \\
\text { ção / desvalorização }\end{array}$ & $\begin{array}{l}\text { 4.2.1. Falta de espaço para inovação e/ou proposta de ideias (5) } \\
\text { 4.2.2. Os outros desconhecem o trabalho que exerço (2) } \\
\text { 4.2.3. Não se sente reconhecido (a) (2) } \\
\text { 4.2.4. Passa por desvio de função (2) } \\
\text { 4.2.5. Desmotivação causada pelos problemas recorrentes (2) } \\
\text { 4.2.6. Falta de domínio sobre o próprio trabalho (1) }\end{array}$ \\
\hline 4.3. Centralização de decisões & $\begin{array}{l}\text { 4.3.1. A centralização de decisões atrasa o trabalho (5) } \\
\text { 4.3.2. A centralização tira a liberdade do funcionário resolver pro- } \\
\text { blemas (1) } \\
\text { 4.3.3. As decisões técnicas são centralizadas em quem não tem co- } \\
\text { nhecimento técnico (1) }\end{array}$ \\
\hline 4.4. Burocracia & $\begin{array}{l}\text { 4.4.1. Questões burocráticas atrasam os processos (4) } \\
\text { 4.4.2. Os processos são muito atravessados por outras pessoas (1) } \\
\text { 4.4.3. Toda decisão tem que passar por várias instâncias (2) }\end{array}$ \\
\hline $\begin{array}{l}\text { 4.5. Falta de pessoal / excesso } \\
\text { de trabalho }\end{array}$ & $\begin{array}{l}\text { 4.5.1. Poucas pessoas para lidar com muito trabalho (1) } \\
\text { 4.5.2. Aumento das demandas sem aumento de pessoal (1) } \\
\text { 4.5.3. Falta de pessoal não permite repensar processos (1) } \\
\text { 4.5.4. Equipes são boas, mas muito pequenas (1) }\end{array}$ \\
\hline $\begin{array}{l}\text { 4.6. Problemas de gestão de } \\
\text { pessoas }\end{array}$ & $\begin{array}{l}\text { 4.6.1.Não há gestão de pessoas na Fundação (1) } \\
\text { 4.6.2. Falta mobilizar e incentivar as equipes e conteudistas (1) }\end{array}$ \\
\hline $\begin{array}{l}\text { 4.7. Falta de investimento da } \\
\text { Fundação nos seus profissionais }\end{array}$ & $\begin{array}{l}\text { 4.7.1. Não há incentivo ao estudo e atualização dos profissionais (2) } \\
\text { 4.7.2. Fundação não patrocina cursos para os profissionais (1) }\end{array}$ \\
\hline
\end{tabular}

Tabela 5.13 - Unidades de registro e de contexto da Categoria 4 da análise de conteúdo

Aqui, percebeu-se que os entrevistados enxergam problemas com a organização e o planejamento da Fundação. Quarenta e sete vezes houve menção a questões de falta de planejamento que se relacionam e impactam o trabalho realizado por eles. O que torna esse número mais significativo é que essas menções foram totalmente espontâneas, sem uma pergunta específica sobre planejamento. 
A principal queixa foi sobre a falta de um fluxo de trabalho definido. Não há, segundo essas observações, uma metodologia fixa de trabalho, um cronograma que permita a eles se organizarem. $O$ conteúdo não chega, muitas vezes, de forma padronizada e com o tempo necessário para adaptação para a EAD. Segundo os relatos, demandas chegam repentinamente ao setor, geralmente urgentes e atrasadas, e atrapalham os processos correntes (que, talvez, já sofram com os problemas levantados na unidade de registro anterior). Mais de um entrevistado usou o termo "apagar incêndio" para ilustrar a situação onde estão sempre resolvendo algo emergencial e não planejado ao invés de se dedicarem aos processos em andamento. Onze vezes houve menção à uma falta de organização nos processos e funções da Fundação que impacta diretamente o trabalho deles.

(...) ausência de processos bem estabelecidos. De processos de trabalho. Então, as tomadas de decisões, em nível de Gestão, não são claras, elas não são padrão, e variam de acordo com o contexto (...) a gente não tem um planejamento, surgem projetos do nada com prazos urgentes e que atropelam os projetos que já estão em andamento (Entrevistado 4).

Outra questão surgida espontaneamente foi um sentimento de desvalorização e subutilização. Segundo as entrevistas, a principal razão seria o pouco espaço para inovação e proposição de ideias (5), além de falta de reconhecimento, desvio funcional, desconhecimento sobre o trabalho realizado e desmotivação, entre outras. Também tiveram número de citações relevante (sete, cada): a centralização de tomada de decisões na Fundação e a burocracia. Segundo depoimentos, essas questões se inter-relacionariam, pois a centralização cria uma demora burocrática nas respostas que a equipe necessita e nas definições de projetos e fluxos. Além disso, ela também tiraria dos profissionais uma maior autonomia na tomada de decisões e na sugestão de ideias, o que, como visto acima, incomoda as pessoas.

(...) qualquer pequena diferença (...) vai passar por uma série de perguntas que não são referentes ao serviço porque a pessoa não conhece exatamente o que que você tá fazendo. Então, acaba virando um processo muito longo. E isso, de certa forma, prejudica o funcionamento da Fundação, porque no final das contas você acaba ou passando por todo esse processo e vendo aquilo não acontecer, ou você acaba fazendo à revelia, e arriscando, depois, receber reclamação ou não. Então, essa descentralização da demanda, de tudo ter que ir pra uma pessoa só, porque é uma pes- 
soa só que tem uma árvore gigantesca abaixo dela. Porque não existe definição de nada, tudo tá abaixo de uma pessoa só, e sempre essa pessoa, é uma pessoa que não entende do que você tá fazendo. Isso seria muito bom. (Entrevistado 7)

\subsubsection{5.}

\section{Categoria 5 - Visão sobre as mudanças propostas para o setor}

Reuniu-se, nesta parte, inferências sobre as mudanças propostas e iniciadas para o setor de material didático e se os profissionais percebiam se elas já modificavam (ou não) seu trabalho. Foi especificamente perguntado (nas Questões 9 e 10 da entrevista) sobre a junção dos três antigos setores (Desenho instrucional, Design Gráfico e Mídias Digitais) num grande setor integrado, e sobre o novo modelo de construção das aulas, onde profissionais de todos os subsetores participam do processo desde o início, ao invés da forma anterior, mais "linear". A Tabela 5.14 traz as unidades de registro e contexto dessa categoria:

\begin{tabular}{|c|c|}
\hline \multicolumn{2}{|c|}{ Categoria 5 - Visão sobre as mudanças propostas para o setor } \\
\hline Unidades de contexto & Unidades de registro (ocorrências) \\
\hline $\begin{array}{l}\text { 5.1. Elogio às mudanças propos- } \\
\text { tas }\end{array}$ & $\begin{array}{l}\text { 5.1.1. Elogio à união das } 3 \text { equipes numa só (12) } \\
\text { 5.1.2. Vê a importância das mudanças e as acha positivas (23) } \\
\text { 5.1.3. Elogio ao processo integrado de produção do material (27) }\end{array}$ \\
\hline $\begin{array}{l}\text { 5.2. Críticas ou dúvidas sobre } \\
\text { novas mudanças propostas ou já } \\
\text { executadas }\end{array}$ & $\begin{array}{l}\text { 5.2.1. Ainda não viu a integração da produção funcionando bem (4) } \\
\text { 5.2.2. Tem dúvidas sobre a viabilidade da união das três equipes na } \\
\text { prática (17) } \\
\text { 5.2.3. Tem dúvidas sobre o novo processo integrado de produção } \\
\text { do material na prática (21) }\end{array}$ \\
\hline
\end{tabular}

Considerando-se uma visão quantitativa da análise de conteúdo, o número de menções positivas (61) foi superior às negativas (42). Ainda assim, em alguns depoimentos, mesmo com uma avaliação de que as mudanças são positivas, registrou-se ressalvas e dúvidas sobre se os processos serão exitosos na prática. No campo da visão positiva, apesar de ressalvas, os entrevistados parecem inclinados a elogiar o novo modelo de produção e afirmam que a integração melhoraria o nível das aulas e o trabalho em geral.

Então, quando você tem uma reunião integrada (...) apresenta, por exemplo, um infográfico (...) aí vem o pessoal (...) explica como é que você tem que montar o seu conteúdo, explicando sobre os objetivos, e tem que ter cobrança do objetivo em meio à aula, sabe, toda essa coisa que amarra, amarra o que você escreveu lá em cima nos objetivos com o teu conteúdo desenvolvido na parte de baixo, né? E aí a gente vem também e apresenta o ambiente, o Moodle com suas especificações, a possibilidade de interação entre aluno, entre tutor, as ferramentas (...) ele fica assim espantado, vamos dizer assim, com a gama de recursos que ele pode usar na Educação a distância (Entrevistado 1). 
Já a junção dos três setores, comparativamente, levantou mais dúvidas (17) do que elogios (12):

(...) é uma iniciativa inovadora, dentro da instituição. (...) mais integrativa, colaborativa, e com indicativo de que a gente possa começar a trabalhar de uma maneira mais sistêmica e propondo soluções diferenciadas, de acordo com o contexto e a necessidade do curso ou da disciplina que está sendo desenvolvida nesse modelo. E que me parece muito mais ao encontro do que a gente entende que seria um modelo mais adequado pro desenvolvimento das disciplinas e dos cursos a distância (Entrevistado 4).

$\mathrm{Na}$ verdade, eu acho que são setores diferentes, com especialidades diferentes. Eu acho que esse é o maior entrave que está acontecendo no DI integrado. Por que tem... pra ter um chefe só, ou dois, no caso, de um setor desse inteiro, os dois chefes teriam que conhecer as utilidades dos dois setores. Assim que eu acho. E é o que não acontece (Entrevistado 5).

No que tange a visão das críticas e dúvidas que os profissionais possuem, percebeu-se muitas ressalvas sobre a colocação em prática das mudanças pro-

postas (42 registros). Vinte e uma vezes detectou-se dúvidas sobre os processos de construção das aulas e dezessete vezes sobre a viabilidade da reunião das três equipes em uma só. Também houve, quatro vezes, registros de que o profissional participou de uma disciplina formatada no modelo integrado e não achou positivo.

Termina que esse modelo de criação de disciplina tenta colocar a coisa toda numa fôrma, só que cada disciplina tem sua própria personalidade, o conteúdo da disciplina tem sua própria forma de lidar. (...) você envolver catorze pessoas numa sala pra pensar uma disciplina no início, quando às vezes nem o conteudista ainda sabe direito como ele vai conduzir, é muito complicado. (...) às vezes termina sendo um ruído muito maior, porque vão vir um monte de ideias que podem ser aproveitadas, podem ser descartadas, e isso prolonga mais as reuniões (...) e é bem menos produtivo do que se, talvez, tivesse uma coesão maior entre os designers instrucionais antes de fazer o resumo e passar pros webs, e animadores e ilustradores pra poderem ter um briefing melhor (Entrevistado 2).

\subsubsection{6.}

\section{Categoria 6 - Sugestões de melhoria dos profissionais}

Aqui são compiladas as sugestões de melhoria expressas pelos profissionais ao longo das entrevistas, não só na pergunta específica sobre o assunto (Questão 5). O objetivo principal dessa questão foi fomentar propostas a serem validadas com um maior de número de profissionais na próxima etapa da pesquisa. 
Percebeu-se que as sugestões de melhoria mais comuns foram uma maior integração entre as equipes (17 registros) e melhor planejamento dos processos de trabalho (9 menções). Ambas se relacionam com o que já havia surgido nas questões sobre dificuldades cotidianas. Um ponto bastante interessante foi a sugestão de subcoordenações dentro Departamento de Material Didático, uma para cada antigo setor independente, que pode se relacionar, também, com a questão apontada de centralização das decisões e processos. A Tabela 5.15 traz as unidades de registro e contexto desta categoria:

\begin{tabular}{|l|l|}
\hline \multicolumn{2}{|c|}{ Categoria 6 - Sugestões de melhoria dos profissionais } \\
\hline \multicolumn{1}{|c|}{ Unidades de contexto } & \multicolumn{1}{c|}{ Unidades de registro (ocorrências) } \\
\hline 6.1. Sugestões para processos & 6.1.1. Mais integração entre as equipes (17) \\
do setor de material didático & 6.1.2. Melhor planejamento do processo de trabalho da construção \\
& das aulas (9) \\
& 6.1.3. Criação de subcoordenações dentro do Departamento / descen- \\
& tralização (7) \\
& 6.1.4. Ter equipes "fixas" (um DI, um web, um ilustrador, etc.) por \\
& disciplina (5) \\
& 6.1.5. Um sistema gerenciador de andamento das aulas, acessível \\
& pelos profissionais (3) \\
& 6.1.6. Mais autonomia dos técnicos em relação aos conteudistas (2) \\
& 6.1.7. Mapear as opiniões e problemas dos usuários (2) \\
& 6.1.8. Melhorar o setor de suporte a alunos e professores (2) \\
& 6.1.9. A primeira reunião com o conteudista não precisaria ser com \\
& todas as equipes, e sim com os DIs (2) \\
& 6.1.10. Aproveitamento maior de mídias de impresso em digital e \\
& vice-versa (1) \\
& 6.1.11. Criar/contratar um banco de imagens (1) \\
\hline 6.2. Sugestões para a Fundação & 6.2.1. Mais capacitação de técnicos e conteudistas (3) \\
& 6.2.2. A Fundação deve escutar mais os profissionais (2) \\
& 6.2.3. Valorizar os tutores (2) \\
& 6.2.4. Estimular os conteudistas a escreverem pensando em EAD (1) \\
& 6.2.5. Dar mais autonomia aos professores e conteudistas (2) \\
& 6.2.6. Criar um setor de vídeo-tutoria (1) \\
& 6.2.7. Técnicos serem tão respeitados quanto os acadêmicos (1) \\
\hline Tabela 5.15 - Unidades de registro e de contexto da Categoria 6 da análise de conteúdo
\end{tabular}

Esta categoria foi a principal razão da análise de conteúdo ter sido qualitativa e não apenas quantitativa. Desta forma, ideias interessantes que se relacionam com os problemas encontrados e que não tiveram tantas menções, como a do sistema gerenciador do andamento da produção de aulas, por exemplo, podem ser incluídas na etapa seguinte de validação dos profissionais.

\subsubsection{7. Categoria 7 - Relação dos entrevistados com a EAD}

Pesquisas (ABED, 2014 e 2015) e autores como Moran, Valente e Arantes (2011) apontam possíveis problemas de adaptação de docentes e profissionais à 
EAD. O próprio Governo Federal (BRASIL, 2015) e autores como Mugnol (2009) apontam ainda uma visão historicamente preconceituosa sobre essa modalidade de ensino. Esta parte do levantamento buscou averiguar se essa aversão e preconceito estavam presentes nos profissionais do setor.

Ao menos no grupo entrevistado, não se pôde identificar esse preconceito. Não houve crítica direta à modalidade, apenas preocupação com a qualidade dos cursos oferecidos pelo mercado em geral (nove menções), e a observação que a EAD não funciona para todo tipo de estudante (três registros). Mesmo nesses casos, eram mais uma ressalva do que exatamente uma crítica. A Tabela 5.16 traz as unidades de registro e contexto dessa categoria:

\begin{tabular}{|c|c|}
\hline \multicolumn{2}{|c|}{ Categoria 7-Relação dos entrevistados com a EAD } \\
\hline Unidades de contexto & $\begin{array}{ll}\text { Unidades de registro (ocorrências) } \\
\end{array}$ \\
\hline 7.1. Elogios à EAD & $\begin{array}{l}\text { 7.1.1. EAD é democrática (11) } \\
\text { 7.1.2. EAD é importante (4) } \\
\text { 7.1.3. Teve uma experiência pessoal positiva com EAD (3) } \\
\text { 7.1.4. É uma forma flexível de estudar (2) } \\
\text { 7.1.5. É pedagogicamente rica (1) } \\
\text { 7.1.6. A EAD evoluiu muito (1) }\end{array}$ \\
\hline $\begin{array}{l}\text { 7.2. Preocupações ou críticas à } \\
\text { EAD }\end{array}$ & $\begin{array}{l}\text { 7.2.1. EAD muitas vezes não é feita com o cuidado preciso (9) } \\
\text { 7.2.2. EAD não funciona com todo tipo de aluno (3) } \\
7.2 .3 \text {. Teve experiência pessoal negativa estudando à distância (2) }\end{array}$ \\
\hline $\begin{array}{l}\text { 7.3. Percepção de preconceito } \\
\text { com a EAD }\end{array}$ & $\begin{array}{l}\text { 7.3.1. Preconceito de professores com a EAD (2) } \\
\text { 7.3.2. Preconceito de alunos com a EAD (1) } \\
\text { 7.3.3. Preconceito em geral com a EAD (1) }\end{array}$ \\
\hline
\end{tabular}

(...) muitas vezes eu tenho a sensação que ela é feita na tentativa e erro, como é o caso nas universidades públicas, ou como uma forma de você massificar a quantidade de alunos pra poucos professores, como é o caso de uma universidade particular, que universidade particular tá visando o lucro. (...) nesse aspecto, eu acho assim que a EAD é necessária, porém ela tem que ser mais pensada (Entrevistado 3).

Sobre a questão da aversão de alunos e profissionais à EAD, em quatro oportunidades os entrevistados citaram a percepção de preconceito de outras pessoas em relação à EAD. Mas, no geral, A maior parte das menções (vinte e duas) foram de elogios para a EAD, principalmente no aspecto de democratização do ensino.

Preconceito que algumas pessoas mais conservadoras, principalmente professores, nas instituições mais conservadoras, ainda têm, um pouco, com a EAD. Mas acho que isso é um problema temporário, acho que as próximas gerações realmente não vão ter problema nenhum com isso. As próximas gerações de alunos, né? As de professores, eu ainda não sei (Entrevistado 6). 
Então, como ferramenta de democratização de acesso, é fundamental, porque não vão ser construídas universidades em todos os, né, em todo o interior do Rio, então, é, o ideal seria isso, mas, nesse sentido, já é um primeiro passo pra que haja essa possibilidade de autonomia e de democratização do ensino. Eu acho fundamental, sabe, ensino a distância (Entrevistado 8).

Concluindo, este capítulo apresentou a proposta e a fundamentação do estudo de caso realizado por esta dissertação no departamento de material didático do Cecierj. Também foi exposta a primeira etapa do estudo: as entrevistas estruturadas e sua posterior análise de conteúdo. As dificuldades enfrentadas pelo Estado do Rio de Janeiro tornaram o processo mais trabalhoso e extenso, mas possível graças ao uso de ferramentas como as entrevistas remotas. Não se conseguiu atingir o número de pessoas na exata proporção dos subsetores do departamento, mas, ainda assim, os resultados foram submetidos, avaliados e validados por um número maior e mais proporcional de pessoas na etapa seguinte da pesquisa, reduzindo a chance de viés nos resultados.

As técnicas utilizadas (entrevistas e análise de conteúdo) trouxeram um material muito rico e que foi além dos assuntos diretamente abordados nas perguntas. Dentre os tópicos espontâneos, destacaram-se a necessidade de mais organização e planejamento da Fundação como um todo e as questões que envolvem a participação dos conteudistas externos das universidades. Ofereceram, assim, os insumos necessários para a etapa seguinte da pesquisa, onde se buscou saber: as opiniões levantadas neste capítulo são compartilhadas pelos demais funcionários? Qual o grau de impacto dos problemas apontados no funcionamento do setor? As sugestões de melhoria aqui colhidas seriam aceitas pela maioria dos funcionários? Este material poderia embasar propostas de mudanças no modelo de produção de material e no organograma do setor? São essas questões o que a dissertação abordará a seguir.

No capítulo 6, será explicitado o contexto que levou à escolha dos métodos e técnicas colaborativas da próxima etapa e como o material da análise fomentou as questões apresentadas aos profissionais. 


\section{6 \\ Elaboração colaborativa de uma proposta de melhoria para um sistema de trabalho multidisciplinar de EAD}

Como dito anteriormente, não houve definição prévia de um método ou técnica específico para a realização do levantamento e validação das propostas de mudança para o setor estudado. Partiu-se do princípio levantado no Capítulo 4, de que as ferramentas utilizadas e o nível de participação dos stakeholders dependem do contexto e cenário encontrados. Desta forma, o processo aqui descrito foi definido após as etapas anteriores do estudo de caso e, principalmente, após uma análise do contexto de trabalho da equipe de material didático do Cecierj. Esta escolha é explicada a seguir.

\section{1. \\ Contexto encontrado e escolha do método de pesquisa}

No momento de finalização da análise de conteúdo, o cenário de crise financeira do Estado do Rio havia piorado ainda mais. Não havia certeza nem previsão das datas de pagamento e os atrasos de salário eram ainda maiores. Os servidores, para economizar, passaram a trabalhar remotamente na maior parte da semana. O clima entre os funcionários, por esses motivos, também não era dos mais favoráveis. Assim, qualquer técnica que exigisse uma reunião presencial dos envolvidos foi descartada. Passou-se a analisar qual metodologia funcionaria bem, remotamente, para a obtenção dos melhores resultados objetivados pela pesquisa.

Através do levantamento teórico realizado, identificou-se que o método Delphi seria muito interessante para validar as propostas com um número maior de participantes. Everling e Mont'Alvão (2011) definem a Delphi como uma técnica que permite a minimização de incertezas e a resolução de problemas, através do consenso de especialistas - neste caso, os profissionais do setor estudado. Segundo Cândido et al. (2007, p.161), a aplicação da Delphi acontece através da apresentação de questionários específicos aos participantes. Ocorre da seguinte forma: 1) os resultados do questionário são agregados e tratados; 2) as 
questões onde o pesquisador detecta consenso entre os respondentes são retiradas da pauta; 3) os tópicos não consensuais são reformulados e reapresentados aos participantes. Esse processo é repetido até que se atinja, em todos os assuntos abordados, o grau de consenso necessário. Desta forma, a técnica pode apresentar várias "rodadas" de participação (preferencialmente quatro, no máximo), dependendo do grau de consenso dos especialistas. O processo da Delphi está resumido na Figura 6.1:

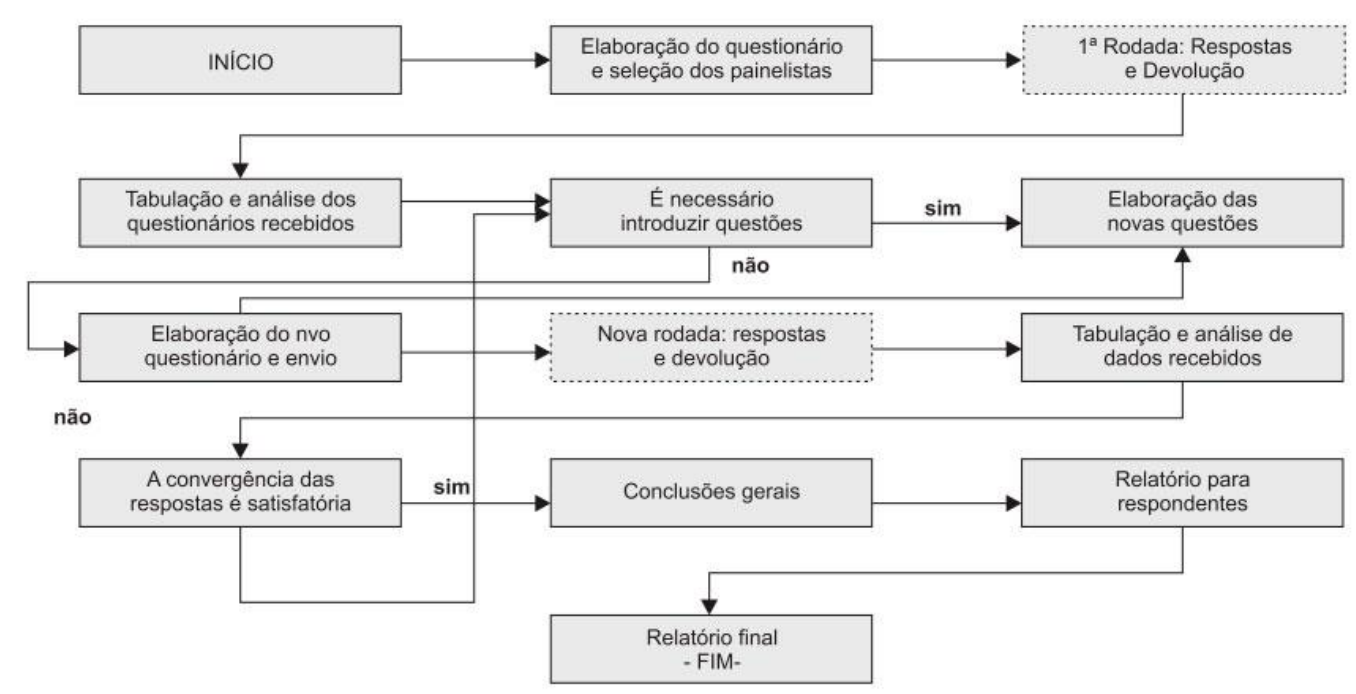

Figura 6.1 - Sequência de execução de uma pesquisa Delphi (Fonte: CÂNDIDO et. al, 2007, baseado em WRIGHT; GIOVINAZZO, 2000)

A vantagem da técnica Delphi é permitir a estruturação da comunicação num grupo de pessoas, facilitando a abordagem coletiva de um problema complexo. Além disso, é um método especialmente voltado para a análise de dados qualitativos (CÂNDIDO et al., 2007, p.161). Essas características são particularmente interessantes para uma pesquisa como a aqui proposta, que visa refinar, com um grupo de profissionais, melhorias para o cotidiano profissional.

Porém, com a piora do cenário econômico dos funcionários, seria arriscado optar por uma técnica que, provavelmente, necessitaria de duas ou três etapas de participação. Os servidores teriam a iniciativa de participar até o final, mesmo se os salários continuassem atrasando? Haveria tempo hábil para iniciar outro processo, caso esse desse errado? De qualquer forma, corria-se o risco de “queimar cartuchos" com pessoas já com pouca disposição.

Desta forma, optou-se por um questionário online, onde as sugestões e impressões surgidas nas observações do autor e na análise de conteúdo das 
entrevistas seriam validadas com um maior número de funcionários. Fez-se essa escolha, pois questionários permitem coletar informações de forma eficaz e reunir uma infinidade de informações que ajudam a projetar produtos (COURAGE; BAXTER, 2005, p.313). Para isso, é necessário que o questionário seja bem planejado e formulado, e que a análise das respostas seja feita de forma adequada. A formatação das perguntas e objetivos do questionário utilizado nesta pesquisa serão abordados a seguir.

\section{2. Questionário online para validação das propostas e sugestões de melhoria}

O questionário é uma ferramenta de coleta de dados acessível que pode ser respondida pelo participante sem a presença do pesquisador (FACHIN, 2003). Courage e Baxter (2005) lembram que o questionário é uma maneira de alcançar um número maior de pessoas, e que pode ser usado como uma atividade autônoma ou - como nesta pesquisa - um complemento a outras técnicas e métodos. No caso em estudo, o uso do questionário online deu maior autonomia aos participantes, que tiveram liberdade para responder anonimamente e fora do ambiente do trabalho. Segundo Fachin (2003), por prescindir da presença do pesquisador, o questionário dá aos respondentes mais anonimato e, muitas vezes, mais segurança. Isso pode se refletir, segundo a autora, em respostas mais verdadeiras. Estas são variáveis importantes nesta pesquisa, onde os funcionários avaliavam seu próprio ambiente de trabalho. O questionário online também permitiu uma pesquisa sem custos, já que foi usada a ferramenta gratuita Google Forms.

Courage e Baxter (2005, p. 316) listam algumas medidas que podem ser tomadas pelo pesquisador na montagem de questionários com maior índice de participação. Entre elas: uso de um texto ou carta de apresentação com informações sobre a finalidade do estudo e o tempo necessário para a conclusão do mesmo; reduzir o número de perguntas abertas; manter o questionário curto, atrativo e fácil de responder; e enviar lembretes educados, incentivando a participação, após o lançamento do questionário. Todas essas medidas foram seguidas nesta pesquisa. 
O questionário elaborado nesta pesquisa contou com um texto introdutório sobre o trabalho em andamento, explicou a etapa anterior das entrevistas e o objetivo das perguntas. Esse texto pode ser visto no Apêndice III da dissertação. A seguir, serão detalhadas as etapas de preparação das perguntas, envio do questionário e análise dos resultados obtidos.

\subsection{1. Redação das perguntas do questionário}

O modelo de Courage e Baxter (2005) diz que se deve evitar o acúmulo de questões abertas, para que o questionário não fique cansativo para os respondentes. Como a proposta deste questionário era medir o grau de concordância com as opiniões e sugestões advindas das entrevistas, optou-se que as respostas seguissem, em sua maioria, uma escala do tipo Likert, com espaço para comentários abertos opcionais. A exceção ficou a cargo de três perguntaschave, que abordavam propostas de mudança estrutural, validação de organogramas e processos de trabalho. Nessas três questões, o respondente obrigatoriamente deveria efetivar um comentário aberto para prosseguir.

Segundo Trojan e Sipraki (2015), a escala Likert surgiu em 1932, criada pelo psicólogo Rensis Likert. Nela, faz-se referência a uma série de afirmações relacionadas com o objeto pesquisado, e o respondente não só exprime sua concordância ou discordância, mas também declara em que grau ela se dá. $\mathrm{Na}$ escala de Likert, os respondentes escolhem em um sistema de cinco categorias de resposta, partindo de "aprovo fortemente" até "desaprovo fortemente". Além disso, a escala também introduzia o caráter bidimensional da escala e um ponto neutro no meio (DALMORO; VIEIRA, 2013). Isso permite identificar "a direção da atitude do respondente em relação a cada afirmação, sendo ela positiva ou negativa" (TROJAN; SIPRAKI, 2015). Citando Lima et al. (2012), os autores lembram que a Likert é a escala mais utilizada em questionários e pesquisas de opinião.

Inicialmente, são coletadas as várias informações sobre determinadas afirmações, em relação às quais são oferecidas opções com graus de intensidade ou importância (...) a avaliação das frases pode ser feita de acordo com as seguintes opções: concordo totalmente, concordo parcialmente, neutra, discordo parcialmente e concordo totalmente (TROJAN; SIPRAKI, 2015, p.281). 
Para Brandalise (2005), as principais vantagens dessa escala são: a sua simplicidade; a possibilidade de incluir qualquer item que seja empiricamente coerente com o resultado; e uma coleta de opinião mais precisa sobre cada afirmação, resultante da amplitude das respostas permitidas. No caso deste questionário, essas afirmações foram retiradas das sugestões e declarações das entrevistas. Alguns desses trechos, muito coloquiais, foram adaptados para os enunciados das questões, mas tiveram seu sentido mantido.

Optou-se pelo formato clássico da escala Likert, com cinco opções de resposta, sendo a intermediária uma opção neutra. Escolheu-se esse modelo por dois motivos: uma escala com mais opções poderia ficar muito cansativa para os respondentes; e uma escala sem opção de neutralidade poderia distorcer a opinião de participantes que não tivessem familiaridade, informações ou conhecimento sobre um determinado assunto, já que eles seriam obrigados a concordar ou não. Citando Campbell (1988) e Tourangeau e Rasinski (1988), Dalmoro e Vieira (2013, p.163) sublinham que o tamanho da escala pode aumentar a complexidade na escolha do respondente e a discriminação entre as opções de resposta. Isso ocorreria, pois responder a uma escala envolve um processo mental de quatro estágios, entre interpretação, julgamento e seleção. Ao mesmo tempo, escalas com poucas respostas podem não discriminar a opinião dos respondentes da melhor forma.

O modelo clássico da Likert apresenta as respostas em formato de linha. Como a ferramenta Google Forms permitia apenas a apresentação das respostas em lista, optou-se por não repetir a mesma ordem de respostas em questões sequenciais. Desta forma, se uma questão trazia como primeira resposta “Concordo totalmente", a questão seguinte começaria pela opção "Discordo totalmente”. Com isso, buscou-se evitar que o questionário ficasse tedioso e que os participantes respondessem as perguntas de forma "automática".

Sobre o número de perguntas, seguiu-se o modelo de Courage e Baxter (2005), onde questionários online devem ter, preferencialmente, por volta de 20 a 25 perguntas, contendo apenas as questões essenciais e relacionadas com os objetivos da pesquisa (COURAGE; BAXTER, 2005, p. 321). Assim, primeiramente montou-se uma lista de perguntas que abordassem todos os tópicos levantados pelos entrevistados na etapa anterior do estudo de caso. A partir daí, foi feita uma depuração, mantendo-se apenas as questões mais importantes e de 
maior relevância, de acordo com os objetivos da pesquisa e os resultados da análise de conteúdo. Desta forma, a pauta final deste questionário conteve vinte e quatro perguntas sobre o cotidiano de trabalho do setor e mais três questões sobre o perfil dos respondentes, totalizando vinte e sete. Das vinte e quatro perguntas sobre trabalho, oito (Questões 1, 5, 6, 14, 15, 16, 17 e 18) não seguiram o modelo Likert, sendo perguntas de validação efetiva de propostas ou comparação de cenários.

Assim como na etapa anterior, aqui também houve preocupação com a ordem das questões na pauta, de acordo com os preceitos de Gil (2002) e Courage e Baxter (2005), já citados. Desta forma, as questões iniciais abordavam assuntos mais familiares aos respondentes, já discutidas nas reuniões internas da Fundação, como junção dos setores e relação entre as subequipes, por exemplo. Perguntas sobre a organização do trabalho e propostas de mudança mais profundas foram introduzidas ao longo da pauta. Questões mais pessoais, como idade e gênero do participante, foram deslocadas para o final. A lista de perguntas é disponibilizada, neste capítulo, no item 6.2.3, onde se analisa as respostas submetidas.

\subsection{2.}

\section{Aplicação do questionário}

Antes da sua aplicação propriamente dita, o questionário foi submetido a um pré-teste, como já ocorrera nas entrevistas na etapa anterior do estudo de caso. Quatro funcionários do setor responderam às questões, e depois discutiram com o pesquisador acerca de suas impressões sobre as perguntas, a linguagem utilizada, a compreensão da proposta e dos objetivos da pergunta, entre outros. Por conta dos problemas enfrentados pelos servidores, três dos quatro participantes eram da equipe de Desenho Instrucional e, o outro, da equipe de suporte. Houve a preocupação de realizar o piloto tanto com funcionários que já haviam participado da entrevista (um), quanto com pessoas tendo o primeiro contato com a pesquisa (três). Dos pré-testes, surgiram algumas modificações, como deixar mais claros os objetivos do questionário e da pesquisa de mestrado e uma barra informativa do número de páginas do questionário.

Após os ajustes, no dia 14 de julho de 2017 o questionário foi enviado aos demais cinquenta e seis servidores do setor, através de correio eletrônico. A 
mensagem continha um texto explicativo e link para o questionário online. $\mathrm{O}$ período de aplicação do questionário se estendeu até $1^{\circ}$ de agosto de 2017 , quando a submissão de respostas foi suspensa. Nesse ínterim, foram enviados lembretes por e-mail, incentivando a participação, nos dias 21 e 31 de julho. Ao fim, trinta e quatro participantes responderam as questões, dando origem ao material que será exibido e analisado a seguir.

\subsection{3.}

\section{Resultados do questionário}

Abaixo, as vinte e sete perguntas do questionário são detalhadas e os resultados obtidos em cada pergunta são listados e analisados.

\begin{tabular}{|c|c|}
\hline \multicolumn{2}{|c|}{$\begin{array}{l}\text { Questão 1- Em 2015, os antigos setores (DI, Impressos e Mídias Digitais) foram reunidos no mesmo } \\
\text { espaço físico. Qual sua opinião sobre essa mudança? }\end{array}$} \\
\hline Opções de resposta & $\begin{array}{l}\text { Número de optantes } \\
\end{array}$ \\
\hline Era melhor antes, com salas separadas & 10 pessoas; \\
\hline É melhor agora, com todos juntos & 11 pessoas; \\
\hline É indiferente & 13 pessoas. \\
\hline \multicolumn{2}{|c|}{$\begin{array}{l}\text { Objetivo da pergunta: validar a questão da junção dos profissionais no mesmo espaço, já abordada nas } \\
\text { entrevistas, com um número maior de funcionários. }\end{array}$} \\
\hline
\end{tabular}

Análise: Apesar do equilíbrio das respostas, dos dez participantes que comentaram voluntariamente, sete disseram ser irrelevante a questão do mesmo espaço físico. É importante notar que após a aplicação dos questionários, durante a análise das respostas, a Fundação mudou de endereço e as equipes voltaram a ficar em salas separadas - uma com revisores, ilustradores e profissionais gráficos; e outra com desenhistas instrucionais, web designers e equipe de vídeo.

\begin{tabular}{|c|c|}
\hline \multicolumn{2}{|c|}{$\begin{array}{l}\text { Questão 2- "As equipes do Material Didático sabem muito pouco da rotina umas das outras. Não } \\
\text { sabem quem faz o quê, como faz, quanto tempo leva." Sobre essa afirmação, você: }\end{array}$} \\
\hline Opções de resposta & Número de optantes \\
\hline Discorda totalmente & 1 pessoa \\
\hline Discorda parcialmente & 2 pessoas; \\
\hline Não concorda, nem discorda & 0 pessoas; \\
\hline Concorda parcialmente & 12 pessoas; \\
\hline Concorda totalmente & 19 pessoas; \\
\hline
\end{tabular}

Análise: Dos seis comentários efetuados, três afirmaram que o problema já melhorara, com a tentativa de implementação de uma maior integração das 
equipes. Um participante disse que existem planilhas, públicas, de controle de produção que explicitam todas as tarefas e duração dos processos, além de documentação sobre o fluxo de trabalho. Sendo o caso, deveriam ser melhor divulgadas ou utilizadas para abastecer um sistema interno de gerenciamento.

\begin{tabular}{|c|c|}
\hline \multicolumn{2}{|c|}{$\begin{array}{l}\text { Questão } 3 \text { - "A falta de comunicação e de integração entre as equipes no setor de Material Didático } \\
\text { dificultam o nosso trabalho." Você: }\end{array}$} \\
\hline Opções de resposta & Número de optantes \\
\hline Concorda totalmente & 13 pessoas; \\
\hline Concorda parcialmente & 12 pessoas; \\
\hline Não concorda, nem discorda & 3 pessoas; \\
\hline Discorda parcialmente & 5 pessoas; \\
\hline Discorda totalmente & 1 pessoa; \\
\hline
\end{tabular}

Tabela 6.3 - Resultados da pergunta 3 do questionário (Fonte: o autor)

Análise: Esse dado é importante, pois explicita que a falta de comunicação tem efeito negativo sobre o trabalho.

\begin{tabular}{|c|c|}
\hline \multicolumn{2}{|c|}{$\begin{array}{l}\text { Questão 4- "Com a fusão dos setores de DI, de Impressos e de Mídias Digitais, ficou muita coisa para } \\
\text { dois diretores gerirem sozinhos". Você: }\end{array}$} \\
\hline Opções de resposta & $\begin{array}{l}\text { Número de optantes } \\
\end{array}$ \\
\hline Discorda totalmente & 4 pessoas \\
\hline Discorda parcialmente & 6 pessoas; \\
\hline Não concorda, nem discorda & 8 pessoas; \\
\hline Concorda parcialmente & 6 pessoas; \\
\hline Concorda totalmente & 10 pessoas; \\
\hline
\end{tabular}

Análise: A maioria concordou em algum grau com a afirmativa. Nos comentários opcionais, dois dos quatro respondentes ressaltaram que enxergam mais um problema geral de gestão e organização como raiz dessa sobrecarga.

\begin{tabular}{|c|c|}
\hline \multicolumn{2}{|c|}{$\begin{array}{l}\text { Questão 5- "O Material Didático poderia ter subcoordenações de DI, de Impressos e de Mídias } \\
\text { Digitais. Assim, as demandas ficariam menos centralizadas nos diretores". Para você, essa é uma boa } \\
\text { proposta? }\end{array}$} \\
\hline Opções de resposta & Número de optantes \\
\hline Sim & 22 pessoas; \\
\hline Não & 6 pessoas; \\
\hline Acho indiferente & 6 pessoas. \\
\hline
\end{tabular}

Análise: Três pessoas comentaram que já existiam as coordenações de Material impresso e Desenho Instrucional - informação que, aparentemente, não é do 
conhecimento de todos os profissionais. De qualquer forma, essa organização do setor não é replicada nas outras equipes do setor (notadamente Mídias Digitais).

\begin{tabular}{|c|c|}
\hline \multicolumn{2}{|c|}{$\begin{array}{l}\text { Questão } 6 \text { - Com base nas entrevistas, a pesquisa propõe um novo organograma para o setor de } \\
\text { Material Didático (ver figura abaixo). Você acha que esta proposta melhoraria o fluxo de trabalho } \\
\text { no setor? }\end{array}$} \\
\hline Opções de resposta & $\begin{array}{l}\text { Número de optantes } \\
\end{array}$ \\
\hline Sim & 19 pessoas; \\
\hline Não & 5 pessoas; \\
\hline Acho indiferente & 10 pessoas. \\
\hline \multicolumn{2}{|c|}{$\begin{array}{l}\text { Objetivo da pergunta: propor e validar um novo organograma para o setor, com subcoordenações } \\
\text { agrupando algumas subequipes com afinidade de processos e tipo de trabalho. Para obtenção de mais } \\
\text { elementos qualitativos, esta questão possuía comentários abertos obrigatórios. }\end{array}$} \\
\hline
\end{tabular}

Análise: A maioria dos respondentes achou que as subcoordenações podem auxiliar na descentralização dos processos. Houve alguma preocupação nos comentários sobre isso acarretar mais burocracia. Alguns acharam que o problema é mais de gestão de pessoas do que de processos. Muitos concordaram com a ideia, mas deram outras sugestões de configuração, como equipe de Vídeo subordinado à de Mídias Digitais e equipe de Animação ligada à de Vídeo. A figura ilustrativa utilizada na pergunta está no Apêndice VI da pesquisa.

\begin{tabular}{|c|c|}
\hline \multicolumn{2}{|c|}{$\begin{array}{l}\text { Questão } 7 \text {-"O Material Didático precisa de um processo de trabalho definido: quando começa a } \\
\text { produção, quando deve terminar, quem participa de qual etapa. E com cronogramas que sejam } \\
\text { respeitados." Você: }\end{array}$} \\
\hline Opções de resposta & $\begin{array}{c}\text { Número de optantes } \\
\end{array}$ \\
\hline Discorda totalmente & 0 pessoas; \\
\hline Discorda parcialmente & 3 pessoas; \\
\hline Não concorda, nem discorda & 3 pessoas; \\
\hline Concorda parcialmente & 9 pessoas; \\
\hline Concorda totalmente & 19 pessoas. \\
\hline
\end{tabular}

Tabela 6.7 - Resultados da pergunta 7 do questionário (Fonte: o autor)

Análise: Uma expressiva maioria dos respondentes concordou totalmente com essa necessidade. Dez pessoas comentaram a pergunta, e mostraram preocupação com as particularidades do processo. Disseram que existem muitas variáveis, que as tarefas (ilustração, DI, animação, etc.) são díspares e isso dificulta a estimativa de um cronograma. Que não se pode estipular um prazo que diminua a qualidade do material. Que os conteudistas externos são uma variável complicada no processo, pois se depende muito deles, e os mesmos não estão sempre disponíveis. 


\begin{tabular}{|c|c|}
\hline \multicolumn{2}{|c|}{$\begin{array}{l}\text { Questão } 8 \text { - "Uma ferramenta interna de acompanhamento da produção - onde se possa ver e } \\
\text { atualizar o andamento do material - traria um fluxo de trabalho mais organizado e preciso". Você: }\end{array}$} \\
\hline Opções de resposta & Número de optantes \\
\hline Concorda totalmente & 25 pessoas; \\
\hline Concorda parcialmente & 4 pessoas; \\
\hline Não concorda, nem discorda & 1 pessoa; \\
\hline Discorda parcialmente & 3 pessoas; \\
\hline Discorda totalmente & 1 pessoa; \\
\hline \multicolumn{2}{|c|}{$\begin{array}{l}\text { Objetivo da pergunta: uma sugestão interessante nas entrevistas foi a do desenvolvimento (ou compra) de } \\
\text { um sistema interno de controle e informação do andamento das diferentes etapas de produção do material } \\
\text { Esta pergunta visa validar essa sugestão com os funcionários. }\end{array}$} \\
\hline
\end{tabular}

Análise: A maioria (29 pessoas) sente falta de uma ferramenta, de um sistema de gerenciamento para acompanhar o andamento das aulas e materiais. Nos comentários opcionais, houve a preocupação com a complexidade do sistema, sobre qual ele seria. Além disso, ressaltou-se que algumas ferramentas já foram tentadas sem sucesso.

\begin{tabular}{|c|c|}
\hline \multicolumn{2}{|c|}{$\begin{array}{l}\text { Questão } 9 \text { - "Deveríamos ter acesso claro e fácil ao perfil dos alunos e à avaliação institucional do } \\
\text { Cecierj. Ajudaria a pensar melhor nosso trabalho." Você: }\end{array}$} \\
\hline Opções de resposta & Número de optantes \\
\hline Discorda totalmente & 0 pessoas; \\
\hline Discorda parcialmente & 0 pessoas; \\
\hline Não concorda, nem discorda & 2 pessoas; \\
\hline Concorda parcialmente & 3 pessoas; \\
\hline Concorda totalmente & 29 pessoas. \\
\hline
\end{tabular}

Tabela 6.9 - Resultados da pergunta 9 do questionário (Fonte: o autor)

Análise: Outro resultado que mostra uma maioria absoluta de concordância com a necessidade de ter acesso facilitado ao perfil dos alunos. Neste caso, essa necessidade é ainda mais reforçada pelo fato de nenhum dos trinta e quatro participantes ter discordado em maior ou menor grau da proposta.

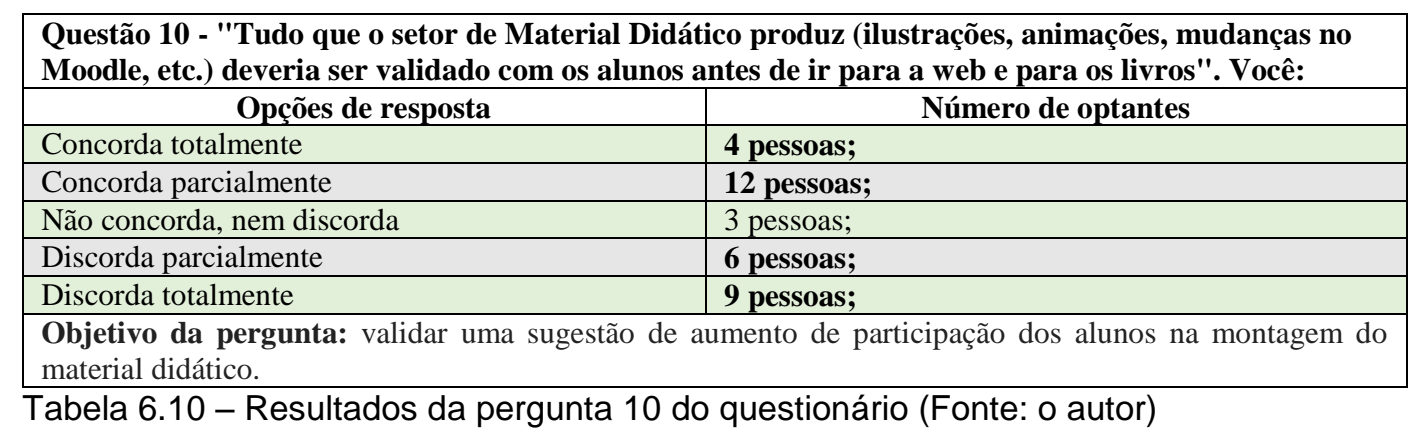

Análise: uma das questões com resultados mais antagônicos. São dezesseis pessoas que concordam em algum grau contra quinze que discordam. Através dos 
comentários espontâneos (13), ficou mais claro que há preocupação com o aumento do tempo do processo, que poderia se tornar “interminável”. Há, também, ressalvas de que a pesquisa com o aluno deveria ser apenas do perfil e da metodologia, e não de todo o material, todas as ferramentas. Sugeriu-se testes apenas em mudanças mais profundas, como no Moodle, por exemplo. Também se fez referência a recolher a opinião do aluno ao fim do curso e não antes do material ir para o ar. Comentou-se também que apenas uma pesquisa bem feita sobre o perfil do aluno já traria uma construção melhor e mais rápida do material.

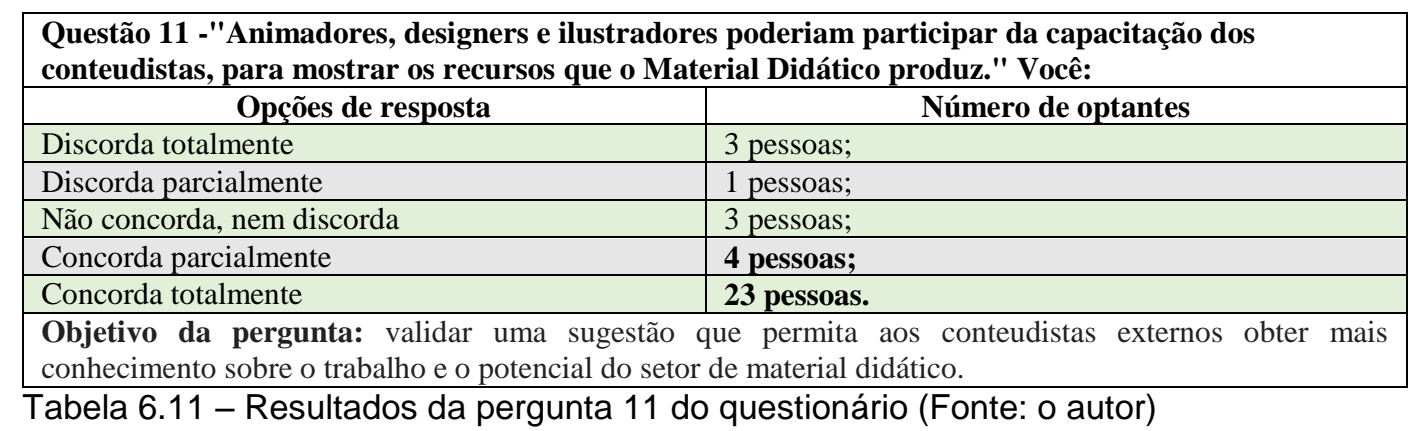

Análise: Nos comentários, surgiram sugestões interessantes para essa participação: capacitações, workshops, imersão dos conteudistas. Essas sugestões serão citadas na conclusão da pesquisa.

\begin{tabular}{|c|c|}
\hline \multicolumn{2}{|c|}{$\begin{array}{l}\text { Questão } 12 \text { - "Os conteudistas das aulas em produção deveriam comparecer periodicamente ao setor } \\
\text { (a cada } 30 \text { dias, por exemplo) para validar o material e tirar dúvidas". Você: }\end{array}$} \\
\hline Opções de resposta & Número de optantes \\
\hline Concorda totalmente & 8 pessoas; \\
\hline Concorda parcialmente & 13 pessoas; \\
\hline Não concorda, nem discorda & 3 pessoas; \\
\hline Discorda parcialmente & 4 pessoas; \\
\hline Discorda totalmente & 6 pessoas; \\
\hline
\end{tabular}

Análise: Aqui, aconteceram muitos comentários espontâneos (13). Neles, mencionou-se bastante que o prazo de trinta dias e o fato de ser uma visita presencial não seriam possíveis na prática. Deu-se a ideia de que os conteudistas acompanhariam o andamento das aulas por uma ferramenta online (talvez, a mesma já proposta nesta pesquisa). Comentou-se bastante que o problema real é o pouco comprometimento dos conteudistas externos e a dificuldade de entrar em contato com eles. Que uma participação mais ativa e solícita já melhoraria a questão. 


\begin{tabular}{|c|c|}
\hline \multicolumn{2}{|c|}{$\begin{array}{l}\text { Questão } 13 \text { - "Às vezes, o conteúdo das aulas chega para o setor muito perto do início da disciplina. } \\
\text { Não dá tempo de preparar o material didático adequadamente." Você: }\end{array}$} \\
\hline Opções de resposta & Número de optantes \\
\hline Discorda totalmente & 0 pessoas; \\
\hline Discorda parcialmente & 1 pessoas; \\
\hline Não concorda, nem discorda & 0 pessoas; \\
\hline Concorda parcialmente & 4 pessoas; \\
\hline Concorda totalmente & 29 pessoas. \\
\hline \multicolumn{2}{|c|}{$\begin{array}{l}\text { Objetivo da pergunta: validar com mais participantes a questão levantada do atraso na entrega do } \\
\text { conteúdo original das aulas e o pouco prazo para produção das aulas e materiais. }\end{array}$} \\
\hline
\end{tabular}

Análise: outra pergunta onde foi reafirmada, por ampla maioria, a necessidade da uma maior integração e participação dos conteudistas. As mudanças estruturais e no processo de trabalho dependem do conteúdo original chegar ao setor a tempo de ser trabalhado e adaptado com qualidade.

Questão 14 - Em 2015, o Cecierj adotou um novo modelo integrado de produção do material didático. Considerando aspectos como fluxo de trabalho, resultados obtidos e qualidade do material, qual dos modelos você diria que funciona melhor?

\begin{tabular}{|l|r}
\multicolumn{1}{c|}{ Opções de resposta } & Nún \\
\hline O novo modelo funciona melhor & 13 pessoas;
\end{tabular}

\begin{tabular}{|l|l}
\hline O modelo antigo funciona melhor & 3 pessoas; \\
\hline
\end{tabular}

Não participei ainda de nenhuma disciplina no novo modelo 18 pessoas.

Objetivo da pergunta: medir, com uma gama maior de participantes, a preferência pelo modelo novo ou pelo antigo de produção do material. Para a obtenção de dados qualitativos e dos motivos pela preferência dos respondentes, os comentários nesta questão eram obrigatórios.

Tabela 6.14 - Resultados da pergunta 14 do questionário (Fonte: o autor)

Análise: Nos comentários, a ampla maioria disse que a crise do Estado não permitiu avaliar a qualidade do novo modelo, mas que a princípio creem ser superior ao anterior. A dificuldade de implementação fica clara ao notarmos que a maioria (18 pessoas) não participou ainda do novo modelo na prática.

\begin{tabular}{|c|c|}
\hline \multicolumn{2}{|c|}{$\begin{array}{l}\text { Questão } 15 \text { - Tendo participado de alguma disciplina "integrada", você diria que o novo modelo já } \\
\text { está funcional? As equipes conseguem trabalhar bem nesse formato? }\end{array}$} \\
\hline Opções de resposta & Número de optantes \\
\hline Não, ainda não funciona bem. & 16 pessoas; \\
\hline Sim, já funciona bem & 4 pessoas; \\
\hline Não participei ainda de nenhuma disciplina no novo modelo & 16 pessoas. \\
\hline \multicolumn{2}{|c|}{$\begin{array}{l}\text { Pergunta condicional nesta mesma questão - Se você já participou de alguma disciplina no novo } \\
\text { modelo integrado, que nota daria para o processo, de } 1 \text { (péssimo) a } 5 \text { (ótimo)? }\end{array}$} \\
\hline \begin{tabular}{|l|l|} 
Opções de resposta & \\
\end{tabular} & Número de optantes \\
\hline Nota 1 & 0 pessoas; \\
\hline Nota 2 & 3 pessoas; \\
\hline Nota 3 & 14 pessoas; \\
\hline Nota 4 & 3 pessoas; \\
\hline Nota 5 & 0 pessoas. \\
\hline $\begin{array}{l}\text { Objetivo das perguntas: nas entrevistas, citou-se que o no } \\
\text { de forma completa. Essa pergunta busca a opinião de ma } \\
\text { avaliação da experiência de quem já participara do novo mod }\end{array}$ & $\begin{array}{l}\text { modelo ainda não funcionava na prática ou } \\
\text { respondentes sobre o assunto e também a }\end{array}$ \\
\hline
\end{tabular}

Tabela 6.15 - Resultados da pergunta 15 do questionário (Fonte: o autor) 
Análise: Mais uma vez, um número expressivo de respondentes afirmou não ter participado de nenhuma experiência no novo modelo. Nos comentários, novamente houve bastante referência ao fato da crise do Estado interferir na avaliação do modelo. A pergunta condicional, por não ser obrigatória, teve vinte respondentes.

\begin{tabular}{|c|c|}
\hline \multicolumn{2}{|c|}{$\begin{array}{l}\text { Questão } 16 \text { - A primeira reunião com o conteudista da disciplina deveria ser com todas as equipes do } \\
\text { setor ou só com os DIs? }\end{array}$} \\
\hline Opções de resposta & Número de optantes \\
\hline $\begin{array}{l}\text { Como o início é muito embrionário, só com os DIs. Eles } \\
\text { depois passariam a proposta da disciplina para os outros }\end{array}$ & 13 pessoas; \\
\hline $\begin{array}{l}\text { Com todas as equipes do Material Didático, para agilizar a } \\
\text { produção e evitar retrabalho }\end{array}$ & 19 pessoas; \\
\hline Acho indiferente & 2 pessoas. \\
\hline
\end{tabular}

Tabela 6.16 - Resultados da pergunta 16 do questionário (Fonte: o autor)

Análise: Apesar de comentários de que reuniões longas são improdutivas, os respondentes afirmam ser importante a presença de representantes de todas as subequipes desde o início do processo.

Questão 17 - Das opções abaixo, qual você diria que é a melhor forma das equipes trabalharem juntas nas disciplinas?

\begin{tabular}{l|l} 
Opções de resposta & Número de optantes
\end{tabular}
Trabalho em núcleos fixos: um DI sempre atuaria com o 3 pessoas; mesmo ilustrador, os mesmos designers, o mesmo animador, etc. - Isso traria entrosamento e, como resultado, um produto mais "coeso".

Rodízio de profissionais: diferentes DIs trabalhando com diferentes designers, ilustradores, animadores, etc. - Permite maior integração entre as equipes do setor e maior troca de experiências, o que enriquece o processo.

Acho indiferente

Objetivo da pergunta: nas entrevistas, surgiu a proposta das equipes trabalharem de forma "fixa" e não no rodízio proposto no novo modelo. Esta pergunta visa medir a opinião dos profissionais sobre essa proposta. Tabela 6.17 - Resultados da pergunta 17 do questionário (Fonte: o autor)

Análise: A grande maioria prefere manter o formato atual, de rodízio.

\begin{tabular}{|c|c|}
\hline \multicolumn{2}{|c|}{$\begin{array}{l}\text { Questão } 18 \text { - Abaixo, propõe-se uma revisão do modelo integrado de produção do material. Ela } \\
\text { inclui maior participação dos alunos e dos conteudistas. Comparado com o modelo atual, que nota } \\
\text { você daria para esta proposta, de } 1 \text { (péssima) a } 5 \text { (ótima)? }\end{array}$} \\
\hline Opções de resposta & Número de optantes \\
\hline Nota 1 & 1 pessoa; \\
\hline Nota 2 & 2 pessoas; \\
\hline Nota 3 & 7 pessoas; \\
\hline Nota 4 & 20 pessoas; \\
\hline Nota 5 & 4 pessoas. \\
\hline \multicolumn{2}{|c|}{$\begin{array}{l}\text { Objetivo das perguntas: baseado nos pontos levantados nas entrevistas, apresentou-se um novo modelo } \\
\text { de produção que incluísse a participação e validação dos conteudistas e alunos, e cujo início se desse com } \\
\text { mais tempo hábil para uma melhor produção do material. Para que os respondentes trouxessem dados } \\
\text { qualitativos sobre a proposta, os comentários a esta questão eram obrigatórios. }\end{array}$} \\
\hline
\end{tabular}

Tabela 6.18 - Resultados da pergunta 18 do questionário (Fonte: o autor) 
Análise: Nos comentários, apesar da aprovação à proposta, houve muita dúvida sobre a participação dos alunos. Alguns acharam desnecessária, outros acharam que tornaria o processo muito longo e que não funcionaria na prática. Houve mais de uma vez a sugestão de que a avaliação pelos alunos fosse feita apenas no final, ou ao longo, da disciplina. Segundo eles, antes das aulas irem ao ar, os materiais seriam construídos de acordo com o perfil dos estudantes. A imagem do modelo proposto, que ilustrou esta pergunta no questionário, está disponível no Apêndice VII da dissertação.

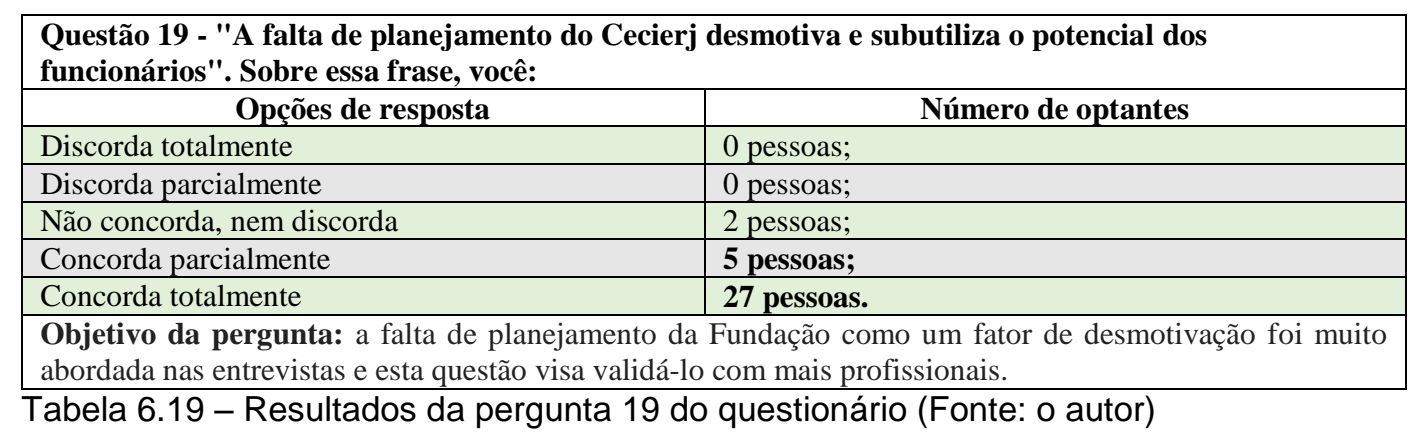

Análise: Os entrevistados amplamente demonstraram se sentir desmotivados e subutilizados por causa da falta de planejamento da Fundação Cecierj. O mais impactante é não ter havido um voto sequer de discordância parcial ou total.

\begin{tabular}{|c|c|}
\hline \multicolumn{2}{|c|}{$\begin{array}{l}\text { Questão } 20 \text { - "Assim como avaliam os cursos e os polos, poderiam nos chamar para avaliar o setor } \\
\text { em que trabalhamos, as aulas e o Cecierj. Dar nossa opinião sobre o que pode ser melhorado." Você: }\end{array}$} \\
\hline Opções de resposta & Número de optantes \\
\hline Concorda totalmente & 25 pessoas; \\
\hline Concorda parcialmente & 3 pessoas; \\
\hline Não concorda, nem discorda & 1 pessoa; \\
\hline Discorda parcialmente & 2 pessoas; \\
\hline Discorda totalmente & 3 pessoas; \\
\hline \multicolumn{2}{|c|}{$\begin{array}{l}\text { Objetivo da pergunta: um ponto recorrente nas entrevistas foi a da falta de participação dos funcionários, } \\
\text { que eles eram pouco ouvidos. Esta pergunta busca validar uma sugestão de avaliação periódica do setor, da } \\
\text { Fundação e do material criado. }\end{array}$} \\
\hline
\end{tabular}

Análise: A grande maioria acha importante essa avaliação interna. Aparentemente, é mais uma demonstração de que os entrevistados querem participar mais das decisões e serem mais ouvidos pela Fundação Cecierj. 


\begin{tabular}{|c|c|}
\hline \multicolumn{2}{|c|}{$\begin{array}{l}\text { Questão } 21 \text { - "Eu já tive ideias, sugestões de implementação, mas foram 'barradas'. A gente não tem } \\
\text { espaço para inovar." Você: }\end{array}$} \\
\hline Opções de resposta & Número de optantes \\
\hline Discorda totalmente & 2 pessoas; \\
\hline Discorda parcialmente & 9 pessoas; \\
\hline Não concorda, nem discorda & 5 pessoas; \\
\hline Concorda parcialmente & 11 pessoas; \\
\hline Concorda totalmente & 7 pessoas. \\
\hline
\end{tabular}

Análise: Apesar da maioria concordar, percebe-se um número relativamente alto de pessoas que discordam em algum grau (onze respondentes). Nos comentários, citou-se que muitas vezes as sugestões não são acatadas ou consideradas por motivos de limitação técnica ou falta de tempo hábil para sua realização.

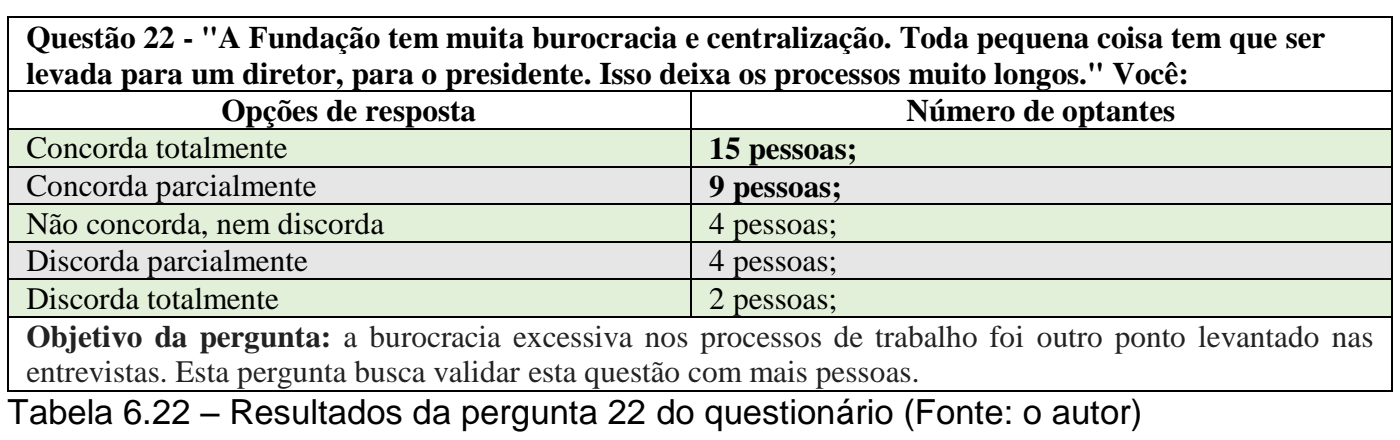

Análise: Um dos comentários desta questão diz: “A fundação tem características de uma empresa familiar, centralizadora, em que não se dá autonomia aos funcionários". Como visto no Capítulo 3 (HENDRICK; KLEINER, 2008), pelo tipo de perfil profissional e de tarefa desempenhada no setor de material didático, é mais apropriada uma menor centralização dos processos e decisões, ao menos no departamento abordado na pesquisa.

\begin{tabular}{|c|c|}
\hline \multicolumn{2}{|c|}{$\begin{array}{l}\text { Questão } 23 \text { - "Poderíamos ser consultados periodicamente sobre a necessidade de compra ou de } \\
\text { atualização dos softwares e dos computadores." Você: }\end{array}$} \\
\hline Opções de resposta & Número de optantes \\
\hline Discorda totalmente & 0 pessoas; \\
\hline Discorda parcialmente & 1 pessoas; \\
\hline Não concorda, nem discorda & 1 pessoas; \\
\hline Concorda parcialmente & 6 pessoas; \\
\hline Concorda totalmente & 26 pessoas. \\
\hline \multicolumn{2}{|c|}{$\begin{array}{l}\text { Objetivo da pergunta: como visto no Capítulo } 4 \text {, o ambiente e as ferramentas são fundamentais para o } \\
\text { funcionamento de um sistema sociotécnico de trabalho. Esta pergunta aborda uma questão surgida também } \\
\text { nas entrevistas: funcionários lidando com computadores e programas desatualizados, o que atrapalharia a } \\
\text { sua performance profissional. }\end{array}$} \\
\hline
\end{tabular}


Análise: Nos comentários, alguns respondentes ressaltaram que até são consultados sobre a questão, mas não há verba para a constante atualização dos micros e dos softwares. Apesar das dificuldades financeiras e burocráticas na aquisição de produtos no serviço público, é importante que a Fundação tenha atenção para a questão, que é fundamental para a produção do setor.

\begin{tabular}{|l|c|c|}
\hline \multicolumn{2}{|c|}{ Questão 24 - Qual sua equipe no setor de Material Didático? } \\
\hline \multicolumn{1}{|c|}{ Opções de resposta } & Respondentes & Funcionários das equipes aptos a responder \\
\hline Animação & 2 pessoas & 2 pessoas \\
\hline $\begin{array}{l}\text { Desenho Instrucional (DI) para } \\
\text { impresso }\end{array}$ & 7 pessoas & 21 pessoas \\
\hline Desenho Instrucional (DI) para Web & 5 pessoas & \\
\hline Design gráfico & 9 pessoas & 10 pessoas \\
\hline Ilustração & 1 pessoa & 5 pessoas \\
\hline Produção gráfica & 0 pessoas & 2 pessoas \\
\hline Revisão & 5 pessoas & 8 pessoas \\
\hline Suporte & 0 pessoas & 1 pessoa \\
\hline Vídeo & 1 pessoa & 2 pessoas \\
\hline Web design & 3 pessoas & 5 pessoas \\
\hline Prefiro não responder & 1 pessoa & -- \\
\hline $\begin{array}{l}\text { Objetivo da pergunta: avaliar a participação dos funcionários das diferentes equipes e relacionar as } \\
\text { respostas com o número de profissionais de cada subsetor. }\end{array}$ \\
\hline
\end{tabular}

Análise: É importante citar que os quatro funcionários que participaram do préteste (três DIs e um profissional de suporte) não foram incluídos nesta etapa da entrevista, assim como o autor desta dissertação. Desta forma, cinquenta e seis profissionais do setor de material didático receberam os convites para preencher o questionário. Cabe dizer que a separação entre DIs de impressos ou de Web não existe mais formalmente, mas como muitos funcionários ainda fazem cotidianamente esta distinção, foi incluída desta forma no questionário. Ressaltase o caso das duas equipes que registraram nenhuma participação: na Produção Gráfica, como já dito, um dos dois profissionais está em licença maternidade apesar de ter sido contatada a participar - e, por isso, talvez o outro servidor tenha preferido não responder ou não se identificar. No Suporte, um dos dois profissionais já realizara o pré-teste. Desta forma, enviou-se apenas um convite de participação para esta equipe. Aqui cabe uma consideração deste autor: fosse um ambiente menos problemático e com mais disposição colaborativa, todos os prétestes seriam realizados com profissionais de equipes mais numerosas, para não reduzir o número de participantes aptos dos times menores. 
Já a Questão 25, se referia ao gênero dos participantes, e objetivava comparar a participação por gênero com a divisão do total de funcionários neste quesito. Vinte pessoas se identificaram como do gênero feminino, dez como do gênero masculino e quatro preferiram não responder (Figura 6.2).

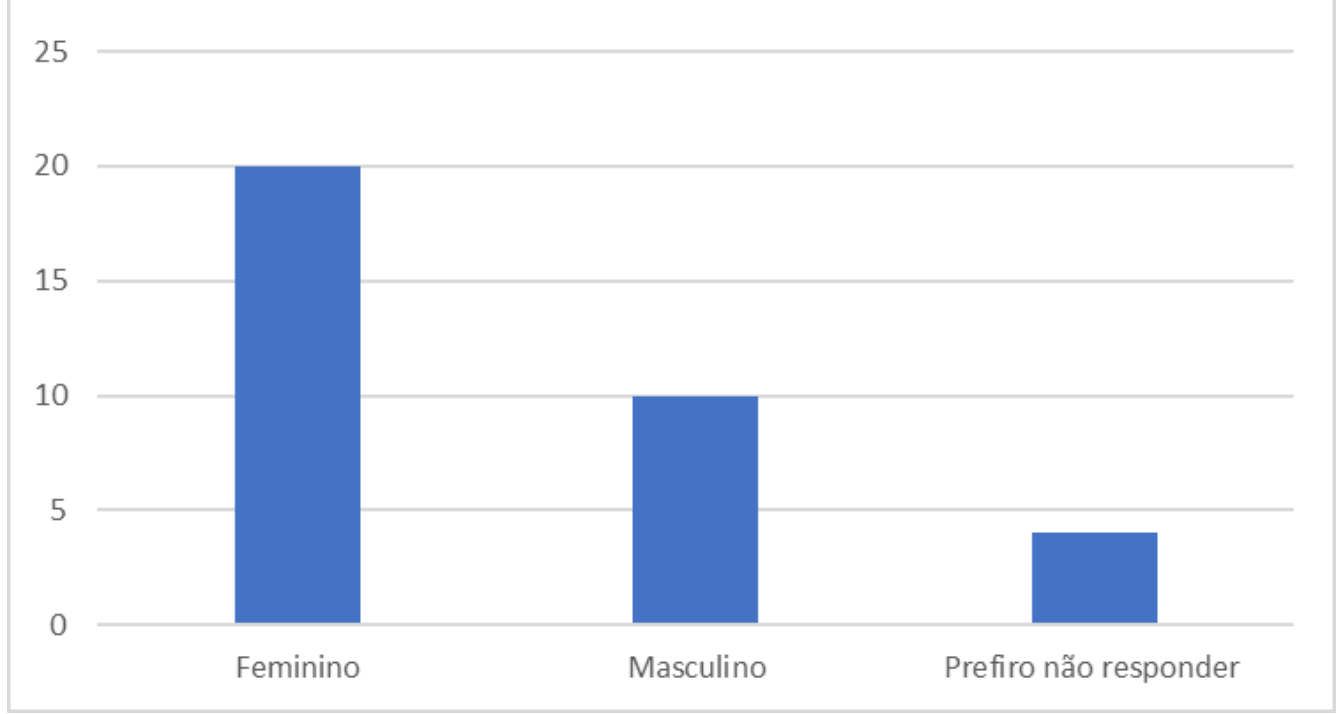

Figura 6.2 - Divisão do número de respondentes do questionário, por gênero (Fonte: o autor)

Levando em conta que, dos sessenta servidores do setor, tem-se 35 mulheres e 25 homens, era esperada uma maioria feminina de respondentes. Como quatro pessoas optaram por não declarar seu gênero, não se pode afirmar o quão maior foi a proporção feminina em relação à masculina.

A Questão 26 perguntou a idade dos participantes, e foi uma forma, juntamente com a Questão 27, de verificar a vivência e a experiência profissional dessas pessoas. As respostas estão disponíveis na Figura 6.3.

Analisando os resultados desta pergunta, percebe-se que os respondentes são, em sua maioria, mais jovens. Dos trinta e quatro participantes, treze têm entre 25 e 35 anos e outros treze entre 36 e 40 anos. Enquanto isso, apenas oito pessoas têm mais de 40 anos. 


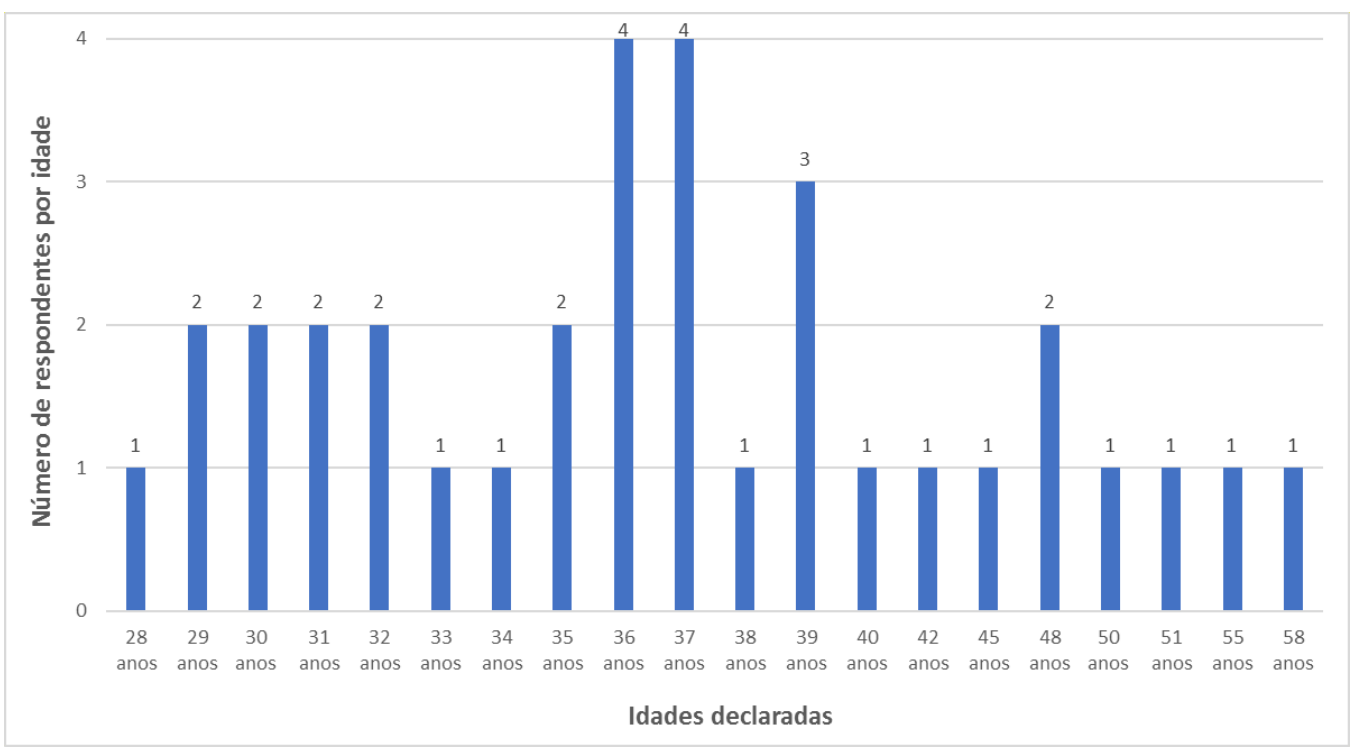

Figura 6.3 - Idades declaradas pelos respondentes (Fonte: o autor)

Por fim, a Questão 27 perguntou o tempo de trabalho na Fundação Cecierj dos participantes. O objetivo foi medir se o nível de experiência e de conhecimento da instituição dos participantes. As respostas foram agrupadas de acordo com as convocações de aprovados em concursos públicos para cargos no setor: Mais de dez anos (concurso de 2006), Entre quatro e dez anos (reclassificação do concurso, ocorrida em 2010); e Até quatro anos (concurso de 2013). Cabe dizer que esta era uma questão aberta, onde se podia colocar qualquer período de tempo. Assim, os funcionários mais recentes que responderam " 3 anos e um mês" ou "3 anos e dois meses" foram agrupados na opção "Até quatro anos". Outro detalhe que merece menção é que o fato de um profissional ter dez anos de Fundação não quer dizer que ele, necessariamente, entrou no concurso de 2006. Há casos de profissionais que trabalhavam como terceirizados ou comissionados e só se tornaram concursados em 2010 ou 2013. Cabe dizer também que a maior participação de funcionários recentes reflete o perfil do setor, pois o concurso de 2013 teve mais vagas que o de 2006 e sua reclassificação, em 2010. O resultado pode ser visto na Figura 6.4. Assim, se poderia dizer que um perfil dos respondentes foi caracterizado por mulheres, com idade entre 31 e 40 anos, e com experiência de três anos no Cecierj. 


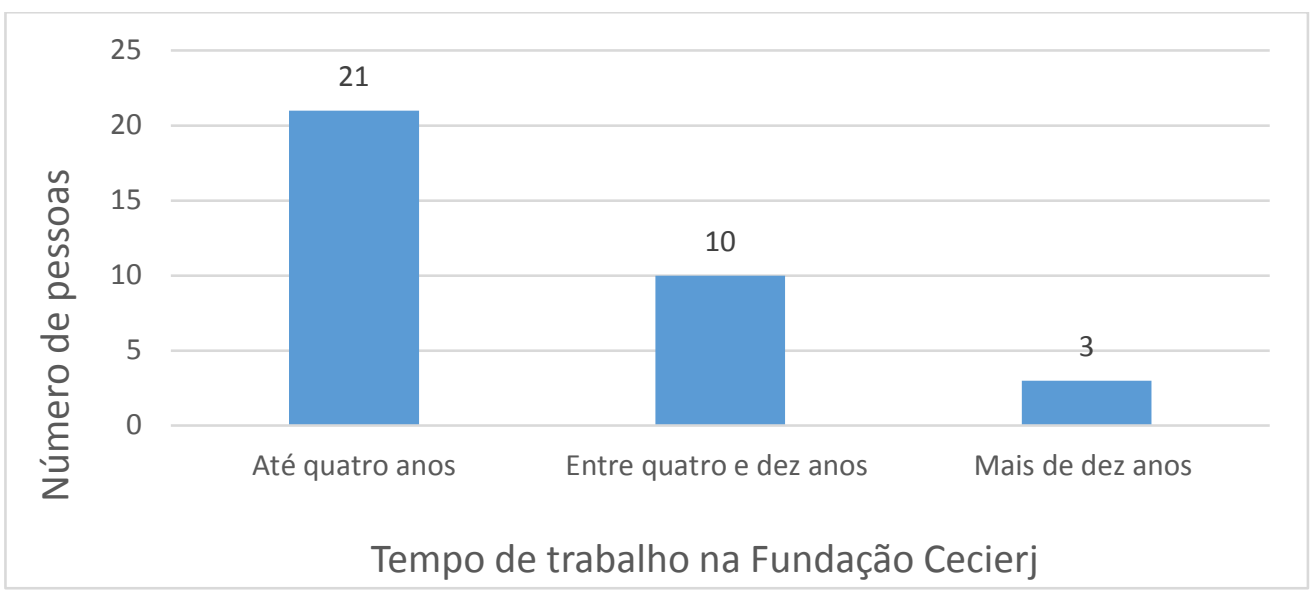

Figura 6.4 - Tempo de trabalho na Fundação Cecierj declarados pelos respondentes, agrupados pelas datas dos concursos públicos realizados (Fonte: o autor)

Apresentados e analisados os resultados do questionário online, no próximo capítulo será abordada a conclusão da parte textual desta dissertação. Serão apresentadas as sugestões de melhoria levantadas no estudo de caso, além das reflexões, conclusões e desdobramentos futuros desta pesquisa. 


\section{7 \\ Conclusões e desdobramentos futuros}

Neste capítulo, o autor reflete sobre suas experiências vividas nesta pesquisa e projeta os desdobramentos futuros que dela podem advir. Para finalizar o estudo de caso, também serão apresentadas aqui as sugestões de melhoria e mudanças para o setor de Material Didático da Fundação Cecierj, o objetivo principal desta dissertação.

\section{1.}

\section{Conclusões e reflexões sobre a pesquisa}

Esta dissertação nasceu de observações e experiências vividas em doze anos de trabalho na área de EAD e suas mídias digitais. Tendo especialização em Design, Interação Humano-Computador e Arquitetura da Informação, minha maior preocupação era a de criar interfaces e experiências ajustadas ao perfil e necessidades dos usuários. Mas, com o tempo, percebi que grande parte dos problemas e dificuldades que enfrentava no dia a dia, em diferentes empresas, eram mais profundos e de ordem estrutural. Eu, um desenvolvedor, também me sentia como um usuário "intermediário", também tinha necessidades e um perfil que precisavam ser atendidos na busca pelo melhor produto possível. Experimentava a dificuldade de interação entre os diferentes profissionais que compunham as equipes multidisciplinares e a pressão que o rápido desenvolvimento tecnológico exercia sobre nós. Senti que era que preciso uma visão mais global dos processos e o uso das boas práticas que aprendera na minha especialização. Se eu e meus colegas de trabalho éramos usuários, se interagíamos com a organização, com o material produzido e entre nós mesmos, não poderíamos também ser abordados e pesquisados pelas metodologias do Design? Se sim, no que isso seria diferente dos métodos tradicionais de gestão de pessoas? O QUEM FAZ não é tão importante quanto o PARA QUEM SE FAZ? Com este pensamento, a pesquisa foi submetida para o Programa de Pós-Graduação da PUC-Rio. 
Algumas questões que moveram esta dissertação foram: podemos utilizar metodologias colaborativas do Design e da Ergonomia aplicadas na gestão dessas pessoas e processos? Como? Podemos usar o Design para pensar uma estrutura processual comprometida com a qualidade do conteúdo do material e das ferramentas ofertadas? Como usar essas metodologias para ajudar os atores envolvidos a resolver ou prevenir essas questões? Como podemos entender e identificar melhor as pessoas que participam dessa construção multidisciplinar e limitar o ruído de comunicação entre elas? Como podemos tornar o ambiente da EAD, que para muitos causa estranhamento, menos inóspito?

Ao longo do curso, pude estudar diversas metodologias do Design e da Administração que eu não conhecia a fundo. Mas, sendo um aluno do LEUI (Laboratório de Ergodesign e Usabilidade de Interfaces), inevitavelmente tive contato com os métodos e técnicas organizacionais da Ergonomia, e eles me trouxeram uma visão mais ampla do que - e como - eu deveria abordar na minha pesquisa. Isso foi importante para avaliar o ambiente de trabalho estudado e para formular as questões da entrevista e do questionário. No Capítulo 4, as metodologias organizacionais do Design e da Ergonomia foram comparadas e relacionadas. Isso as levou a serem agrupadas em suas diferenças e semelhanças. Com base nos conceitos apontados por Moraes (2013), a pesquisa chamou esse agrupamento, a princípio, de "Ergodesign Organizacional". Por agregar tanto visões subjetivas (como a busca pela criatividade e pelo conhecimento tácito), quanto objetivas (contingências contextuais e inter-relações entre organizações e sistemas de trabalho), o Ergodesign pode ser um contraponto interessante à dicotomia que caracteriza o estudo de organizações (ASTLEY; VAN DE VEN, 2007 e CALDAS; FACHIN, 2005). Esta possiblidade também foi abordada no Capítulo 4 e acredito que deveria ser aprofundada em outros trabalhos específicos, reunindo mais metodologias do Ergodesign e expandindo a correlação com o campo da Administração e Gestão. Esta foi uma grata surpresa desta pesquisa e um assunto que espero retomar adiante.

Ao fim do Capítulo 4, esta dissertação destacou que uma abordagem de Ergodesign Organizacional em EAD se basearia em elementos como a centralização dos humanos envolvidos no processo, o cuidado em ouvir e considerar a opinião das pessoas nas decisões que afetem seu trabalho, as especificidades das tarefas realizadas e as demandas e características ambientais. Todas essas questões deve- 
riam pautar o projeto de um sistema de trabalho. É interessante e necessário notar que os resultados obtidos em campo responderam esses questionamentos e encontraram eco no levantamento teórico aqui realizado. Como, por exemplo, de que a tecnologia na EAD demandava dos professores mais participação e respeito aos cronogramas (BENTES, 2009), ou que as organizações modernas devem ser voltadas à criação de processos e valorização das pessoas (CHIAVENATO, 1999). Ou, ainda, a já citada relação entre tipo de tarefa executada, os perfis profissional e cognitivo dos funcionários e o nível de centralização das decisões da empresa (HENDRICK, KLEINER, 2008). Esses resultados mostram que, apesar dos problemas enfrentados pelo Estado no decorrer desta pesquisa, conseguiu-se chegar a uma lista de sugestões e melhorias do sistema de trabalho abordado. E também demonstram que, ao menos no caso estudado, o Ergodesign pode, sim, ser uma ferramenta organizacional aplicável no levantamento de problemas e melhorias para um ambiente multidisciplinar da EAD.

Houve alguns momentos em que se pensou ser impossível contar com a participação dos funcionários. Mas, se o estudo de caso foi concluído no Cecierj, isso se deve à perseverança da equipe de material didático e sua colaboração na pesquisa. O conteúdo das etapas participativas, por eles criado e validado, aponta direções, anseios, questões cotidianas e, principalmente, soluções. Espera-se que esses pontos possam ser abordados coletivamente pela organização no futuro.

O problema central que norteou esta pesquisa foi: "como utilizar o Design e a Ergonomia para elaborar, colaborativamente, propostas de mudanças na cultura de trabalho e na gestão de pessoas e de processos, em ambientes multidisciplinares de EAD?" Após todo o levantamento bibliográfico e o estudo realizado, ao menos no caso desta pesquisa, se poderia responder esta questão da seguinte forma: reunindo a abordagem humanística do Design e a abordagem sistêmica e contextual da Ergonomia. E encará-las não como um mero conjunto de métodos e técnicas, mas como uma visão, uma "filosofia" organizacional. Foi essa reunião que pautou a observação, o estudo e a abordagem do sistema de trabalho, fornecendo um "mapa" abrangente do setor de material didático do Cecierj. Com posse desses dados - e considerando-se a visão organizacional do ergodesign - pôde-se escolher os métodos e técnicas que melhor se encaixassem no sistema estudado, num processo que sempre buscou e se norteou pela participação dos atores envolvidos. Foi desta forma que esta pesquisa obteve a lista de sugestões de melhoria 
para o setor de material didático da Fundação Cecierj, que será apresentada a seguir.

\section{2 .}

Sugestões de melhoria e mudança para o setor de Material Didático da Fundação Cecierj

Abaixo, lista-se as sugestões resultantes desta pesquisa, baseadas nos conceitos levantados nos Capítulos 2, 3 e 4 e no material coletado nas entrevistas e validado no questionário.

Pouca integração entre as subequipes do setor - esta é uma questão tão presente no ambiente estudado que a própria Fundação buscou formas de atenuá-la através de reuniões e da junção dos três antigos setores. No levantamento feito por esta pesquisa, ficou claro que, para os servidores, a falta de integração e de comunicação dificultam o exercício de suas atividades. A Fundação deveria intensificar, assim que a situação financeira for normalizada, a troca de informações entre as equipes e as dinâmicas coletivas de integração entre os profissionais. As informações sobre as tarefas e o seu andamento poderiam, também, ser disponibilizadas para todos. A reunião das equipes num mesmo espaço físico foi uma opção que dividiu opiniões e, se for mantida na nova sede, deveria ser abordada e reavaliada coletivamente pelo Cecierj e seus funcionários.

Organograma do setor de Material Didático - após a junção dos departamentos de Material Impresso, Desenho Instrucional e Mídias Digitais em um só setor, a coordenação do Material Didático ficou a cargo de dois diretores. Considerando as respostas das perguntas 4, 5 e 6 do Questionário, propõe-se que os setores de Mídias Digitais, Animação e Vídeo também tenham alguma forma de subcoordenação, como acontece com Material Impresso e D.I. Os subcoordenadores poderiam ser escolhidos pelas próprias equipes, e seriam profissionais com conhecimento técnico em suas áreas e capacidade de resolver questões internas, aliviando, assim, o volume de trabalho dos dois diretores. Com base nas entrevistas, um organograma foi apresentado no Questionário e validado pela maioria dos respondentes (Figura 7.1). Como alguns participantes sugeri- 
ram modificações ao modelo organizacional proposto, eventuais detalhes e ajustes podem ser decididos coletivamente entre diretores e funcionários.

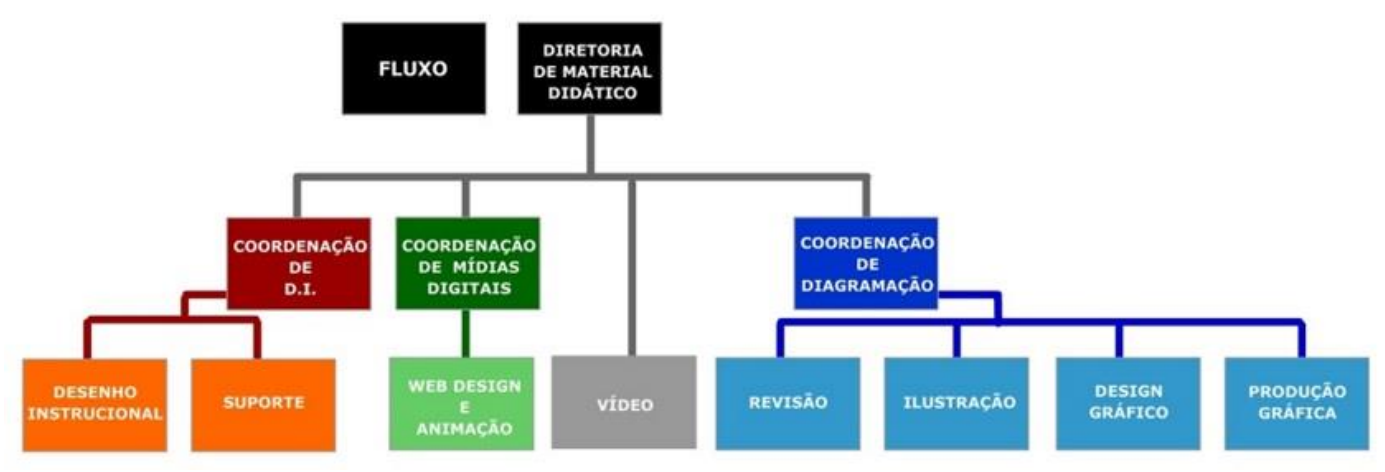

Figura 7.1 - Organograma proposto pela pesquisa para o Setor de Material Didático do Cecierj, validado no questionário online (Fonte: o autor)

Processos de trabalho do setor - Ficou evidente, tanto na análise de conteúdo quanto no questionário, que o setor precisa de um processo mais organizado de trabalho. Como as disciplinas possuem muitas particularidades, o cronograma poderia ser construído aula a aula e estimado pelos profissionais responsáveis, semelhante ao que ocorre em metodologias ágeis como o SCRUM. A questão do conteudista externo aparece como um complicador apontado em todas as etapas de consulta desta pesquisa. Sugere-se fortemente que a Fundação encontre ferramentas que estimulem e facilitem aos conteudistas a entrega do material sempre no prazo. Além disso, que os incentive a participar mais efetivamente do processo, quando necessário. Uma sugestão dada nas entrevistas e amplamente aceita pelos profissionais foi a de uma ferramenta interna de gerenciamento e controle da produção das aulas, onde os funcionários poderiam acompanhar cada passo. A diretoria do setor, juntamente com os profissionais, levantaria as especificidades e necessidades dessa ferramenta e a Fundação pesquisaria no mercado qual produto se adequaria melhor. Outra opção seria criar a própria ferramenta internamente, já que o Cecierj conta com uma equipe de desenvolvimento de sistemas.

Mais pesquisa sobre o perfil dos alunos e acesso a desses dados - Os profissionais deixaram claro que gostariam de ter mais acesso ao perfil do usuário final de seu trabalho. Quando perguntados se a produção do setor deveria ser toda validada com os estudantes, as opiniões se dividiram, pois há um temor de atraso no anda- 
mento do material. De qualquer forma, recomenda-se que os dados dos alunos e da avaliação institucional que o Cecierj realiza anualmente sejam disponibilizados de forma mais fácil e clara. Poderiam ser divulgados na própria intranet da Fundação ou na rede interna, com destaque. Sobre a validação do material com os estudantes, como não houve um consenso expressivo, recomenda-se que essa proposta seja discutida pelo setor conjuntamente. E que sejam levados em conta fatores práticos e a necessidade de se incluir o aluno, de alguma forma, na elaboração dos materiais ou, ao menos, na avaliação dos mesmos ao fim do curso. Já mudanças de interface, por exemplo, deveriam ser validadas pelos alunos desde o início do processo.

Maior participação e interação dos conteudistas externos - Muito se reclamou de que alguns autores entregam o material fora do prazo e muito em cima do início das aulas. Ficou clara a necessidade de se intensificar a participação do conteudista externo no processo de construção do material didático. Como sugerido, os professores poderiam utilizar também a ferramenta de acompanhamento do material. Além disso, visitas presenciais ao setor, ou ao menos alguma ferramenta de contato em tempo real entre a equipe e o conteudista, poderiam ser discutidas em conjunto, para encontro da melhor solução para a questão. É importante que os autores validem os materiais ainda nos estágios iniciais, para evitar atrasos e retrabalho. Também houve expressiva aprovação à sugestão de maior participação dos técnicos na capacitação dos conteudistas. Os autores já têm, ao seu dispor, salas de aula no Moodle onde vão interagir com alunos, ferramentas e a plataforma. Lá, encontrarão exemplos de materiais e tutoriais de aplicação dos mesmos. Mesmo assim, uma participação maior dos técnicos na capacitação poderia trazer mais informações, além de troca presencial de conhecimento e esclarecimento de dúvidas. O melhor formato (workshops, palestras) poderia ser discutido entre os profissionais, coordenadores e conteudistas.

Opção pelo modelo integrado de produção - A maioria dos participantes declarou que não teve a chance de trabalhar no novo modelo de elaboração das aulas. Ainda assim, quem já o fez considerou o novo modelo superior ao antigo. Mesmo com a crise, propõe-se que a nova forma de produção seja mantida e, com a normalização da situação do Governo, seja discutida e avaliada dentro do 
setor. Nesta pesquisa, mediu-se também que a maioria aprova um princípio desse modelo - a presença de representantes de todas as subequipes desde a primeira reunião com os autores. A maior parte dos participantes também preferiu o rodízio de profissionais, como é hoje, ao invés de equipes fixas de trabalho. No questionário, propôs-se uma revisão do modelo integrado de produção, com maior participação de alunos e conteudistas. Ela foi aprovada, mas houve ressalvas quanto a participação ampliada desses atores burocratizar e alongar o processo. Considerando que a maioria acha a proposta positiva, ela poderia ser discutida e ajustada coletivamente pelos profissionais das equipes junto a sua coordenação. O modelo apresentado e validado pelos participantes pode ser visto com mais detalhes e melhor resolução no Apêndice VII da dissertação. Abaixo, na Figura 7.2, um comparativo do modelo de produção do Cecierj adotado em 2016 e 2017 e o modelo proposto por esta pesquisa.
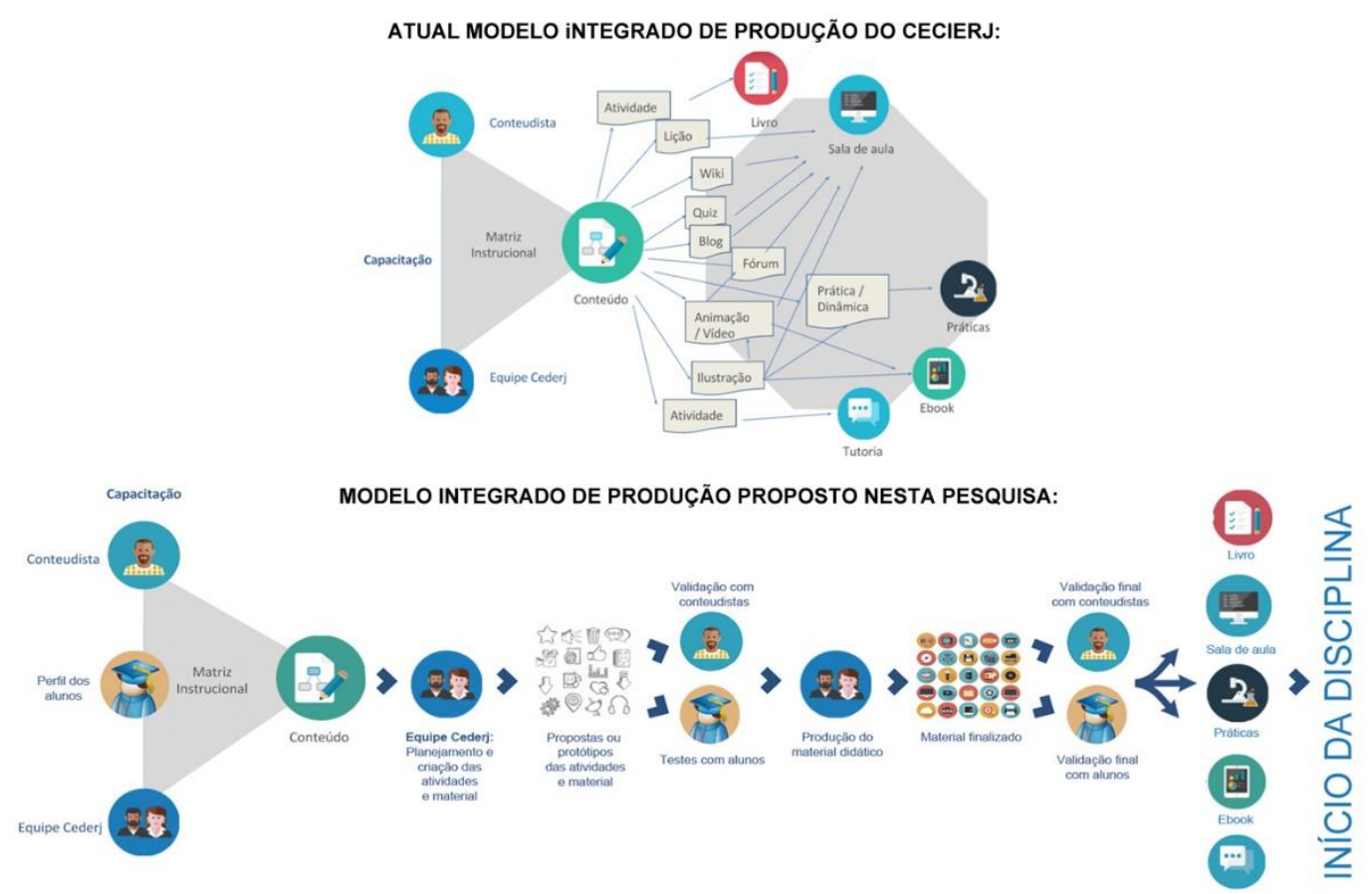

Figura 7.2 - Comparativo entre o modelo de produção adotado pelo Cecierj em 2017 e o proposto e validado pela dissertação (Fonte: Fundação Cecierj / o autor)

Questões da Fundação: burocracia, subutilização e centralização - Uma questão amplamente citada foi a falta de planejamento do Cecierj como um todo, e o quanto isso desmotivava os funcionários. Como visto nos Capítulos 3 e 4 desta dissertação, um planejamento bem feito é fundamental para que os profissionais envolvidos trabalhem melhor. A Fundação deve abordar esse tema assim que pos- 
sível, repensando seus processos e filosofia. Deve, também, considerar o perfil das tarefas e dos profissionais, ajustando seu estilo de gerenciamento de acordo com esses dados. E, preferencialmente, envolvendo os steakholders nesse processo. Sobre centralização e burocracia, um dos respondentes comentou: "A fundação tem características de uma empresa familiar, centralizadora, em que não se dá autonomia aos funcionários". Como visto no Capítulo 4, autores como Kleiner (2008), Perrow (1967) e Hendrick e Kleiner (2008) relacionam o tipo de tarefa e de profissionais envolvidos com o tipo de centralização e formalização do sistema de trabalho. Pelo tipo de perfil profissional (altamente especializado e, em vários casos, com experiência e formação acadêmica) e de tarefa desempenhada no setor de material didático (não rotineira, criativa, multidisciplinar) é mais apropriada uma menor centralização dos processos e decisões. A Fundação poderia envolver mais os funcionários e adotar métodos mais participativos na tomada de decisões. Nas respostas das perguntas 20, 21 e 23 do Questionário, ficou explícito que os profissionais gostariam de ser consultados sobre a qualidade do material, sobre os processos de trabalho e sobre a estrutura que eles recebem para trabalhar. Também disseram que gostariam de ser ouvidos em suas ideias e sugestões. Mais uma vez, propõe-se o aumento da participação e colaboração dos steakholders na gestão da Fundação ou, ao menos, do setor. Poderia ser criada uma (auto) avaliação dos setores da Fundação, onde os funcionários dariam sugestões, opiniões e notas para os processos e funcionamento do seu setor e do Cecierj, como um todo. Se isso não for possível, ao menos que fosse implementada no Departamento de Material Didático. Os responsáveis pela Avaliação Institucional poderiam tocar esse projeto juntamente com o setor.

Chiavenato (1999) lembra que a organização pode escolher entre tratar as pessoas como recursos (administrados e controlados) ou como parceiros (construindo o capital intelectual da empresa). De modo geral, pôde-se perceber que no Cecierj adota-se a primeira opção. Através dos resultados da pesquisa, sugere-se à Fundação uma Cultura Organizacional mais colaborativa e participativa, onde seus valores, crenças e compromissos sejam pautados pelo, talvez, único ativo perene das instituições públicas: o quadro de funcionários efetivos. Vários autores abordados nesta dissertação (entre eles, CARAYON; HOONAKKER; SMITH, 
2012, PEW; MAVOR, 2007 e WALKER et al., 2008) focam na importância da construção de sistemas de trabalho onde haja equilíbrio entre as necessidades da empresa e o capital humano por ela empregado.

Mudar uma cultura arraigada dentro de uma organização pode ser difícil, mas, como disse Formiga (2009), no campo da EAD se deve "estar sempre de cabeça aberta às novidades e ser flexível para mudar a qualquer momento. Não é um território para dogmas ou verdades absolutas". O Cecierj poderia mudar sua Cultura Organizacional para um perfil mais inovativo (CAMERON; QUINN, 2006 apud BARRETO et al., 2013): flexível, empreendedor, idealista; com motivação calcada em estímulo, diversificação e criatividade; e com ênfase na aquisição de conhecimentos.

Nesse processo, a Fundação poderia utilizar a abordagem organizacional do Ergodesign não só como uma ferramenta de melhorias, mas como um parceiro de direcionamento do gestor. Isso se daria ao ajudar o administrador a definir objetivos, propostas de gerenciamento, estratégia, tática e operação (HOLLAND; LAM, 2014). O Ergodesign se tornaria, então, um modo de vida de uma organização que se preocupa, sim, com suas obrigações, com o mercado e com o ambiente, mas sem se esquecer que é formada, antes de tudo, por um grupo de pessoas.

\section{3. \\ Desdobramentos futuros}

Para aprofundamento dos conceitos e propostas levantadas nesta dissertação, propõe-se os seguintes desdobramentos futuros:

\section{Aplicar as sugestões validadas e os conceitos de gestão do Ergodesign no coti-} diano da equipe estudada - o complemento mais interessante à dissertação seria não só implementar as sugestões e mudanças sugeridas no estudo de caso, mas também gerir o setor estudado através dos conceitos organizacionais do Ergodesign. Assim, se poderia medir efetivamente, e na prática, o seu grau de funcionamento e sucesso, além de refinar as propostas através da iteratividade do Design. As sugestões aqui levantadas serão repassadas à Fundação Cecierj e espera-se que possam ser colocadas em prática. 
Aplicar, novamente, um estudo de caso no Cederj, em outro momento menos conturbado - desta forma, comparando os novos resultados com os já obtidos, seria possível aferir se a crise financeira teve algum impacto nos dados levantados nesta pesquisa de campo;

Realizar um estudo de caso em outro ambiente EAD de perfil diferente do Cecierj - o Cederj tem algumas particularidades, sendo a principal o fato de ser um consorciamento público de diferentes IES. Além disso, o autor desta dissertação é seu funcionário. Outro estudo de caso, nos mesmos moldes do aqui apresentado, poderia ser feito numa instituição de ensino superior particular, ou autônoma, sem ligação com este autor, para aferição dos resultados e comparação com a experiência descrita nesta dissertação. 


\section{Referências bibliográficas}

ABED - ASSOCIAÇÃO BRASILEIRA DE EDUCAÇÃO A DISTÂNCIA. Censo ead.br: relatório analítico da aprendizagem a distância no Brasil 2014. Curitiba: Ibpex, 2015. Disponível em: <http://www.abed.org.br/censoead2014/CensoEAD2014_portugues.pdf >. Acesso em 09 abr. 2016.

. Censo ead.br: relatório analítico da aprendizagem a distância no Brasil 2013.Curitiba, Ibpex, 2014. Disponível em: <http://www.abed.org.br/censoead2013/CENSO_EAD_2013_PORTUGUES.pdf> . Acesso em 09 abr. 2016.

ANDRADE, F. V.; LOPES, A. M. DE A. EaD: uma história de inovações tecnológicas no Brasil. Citi - 7. Congresso de Tecnologia da Informação. Anais... 2012. Disponível em: <http://www.essentiaeditora.iff.edu.br/index.php/citi/article/view/2779>. Acesso em 09 set. 2016.

ARRUDA, E. P.; ARRUDA, D. E. P. Educação a Distância no Brasil: Políticas Públicas e democratização do acesso ao Ensino Superior. Belo Horizonte: Educação em Revista, v. 31, n. 3, p. 321-338, set. 2015. Disponível em: $<$ http://www.scielo.br/scielo.php?script=sci_arttext\&amp;pid=S0102-

46982015000300321\&amp;lng=en\&amp;nrm=iso>. Acesso em 03 mai. 2016.

ASTLEY, W. G.; VAN DE VEN, A. H. Debates e perspectivas centrais na teoria das organizações. In: CALDAS, M.P.; BERTERO, C.O. Teoria das Organizações. Série RAE - Clássicos. São Paulo: Atlas, 2007. p. 80-116.

BARDIN, L. Análise de Conteúdo. 4. ed. São Paulo: Edições 70, 2011.

BARRETO, H. Aprendizagem por televisão. In: LITTO, F. M.; FORMIGA, M. (Org.). Educação a distância : o estado da arte - Volume 1. São Paulo: Pearson, 2009. p. 449-455.

BARRETO, L. M. T. D. S. et al. Cultura organizacional e liderança: uma relação possível? Revista de Administração, v. 48, n. 1, p. 34-52, 2013. Disponível em: <http://www.rausp.usp.br/busca/artigo.asp?num_artigo=1512>. Acesso em 23 nov. 2016.

BASTOS, E. Á. M. O que fazemos quando fazemos psicologia do trabalho? Psicólogo InFormação, v. 13, n. 13, p. 99-124, 2009. Disponível em: $<$ https://www.metodista.br/revistas/revistasmetodista/index.php/PINFOR/article/view/2083>. Acesso em 21 nov. 2016. 
BATISTA, E. Fordismo, taylorismo e toyotismo: apontamentos sobre suas rupturas e continuidades. 3o Simpósio Lutas Sociais na América Latina. Anais...2008. Disponível em: <http://www.uel.br/grupopesquisa/gepal/anais_iii.html>. Acesso em 26 out. 2016.

BAUER, M. W.; GASKELL, G. Pesquisa Qualitativa com Texto, Imagem e Som: Um manual prático. 13a. ed. Petrópolis: Vozes, 2015.

BEHAR, P. A. Modelos Pedagógicos em Educação a Distância. Porto Alegre: Artmed, 2008.

BENTES, R. D. F.A avaliação do tutor. In: LITTO, F. M.; FORMIGA, M. (Org.). Educação a distância: o estado da arte - Volume 1. São Paulo: Pearson, 2009. p. 166-170.

BOLAND JR., R. J.; COLLOPY, F. Design Matters for Management. In: BOLAND JR., R. J.; COLLOPY, F. (Eds.). Managing as Designing. Stanford: Stanford University Press, 2004. p. 3-18.

BOLTANSKI, L.; CHIAPELLO, È. O novo espírito do capitalismo. 1. ed. São Paulo: WMF Martins Fontes, 2009.

BONOMA, T. Case Research in Marketing: Opportunities, Problems, and Process. Chicago: Journal of Marketing Research, 1985.

BRANDALISE, L. T. Modelos de medição de percepção e comportamento: uma revisão. Laboratório de Gestão Tecnologia e Informação - Universidade Federal de Santa Catarina. Florianópolis: LGTI, 2005. Disponível em: $<$ https://www.researchgate.net/publication/267679506_MODELOS_DE_MEDIC AO_DE_PERCEPCAO_E_COMPORTAMENTO_-_UMA_REVISAO $>$. Acesso em 16 ago. 2017.

BRASIL. Balanço Social SESu 2003-2014. Brasília: Ministério da Educação, 2015. Disponível em: <http://portal.mec.gov.br/sesu-secretaria-de-educacaosuperior/arquivos>. Acesso em 03 mai. 2016.

Censo da Educação Superior 2013 - resumo técnico. Brasília: INEP (Instituto Nacional de Estudos e Pesquisas Educacionais Anísio Teixeira), 2015. Disponível em: <http://download.inep.gov.br/download/superior/censo/2013/resumo_tecnico_cen so_educacao_superior_2013.pdf>. Acesso em 02 mai.2016.

Decreto $n^{0}$ 5.622, que regulamenta $o$ art. 80 da Lei de Diretrizes e Bases da Educação Nacional. Brasília: Diário Oficial da União, 2005. Disponível em: <http://www.planalto.gov.br/ccivil_03/_Ato20042006/2005/Decreto/D5622.htm>. Acesso em 02 mai.2016.

Lei no 9.394, que estabelece as Diretrizes e Bases da Educação Nacional. Brasília: Diário Oficial da União, 1996. Disponível em: <http://www.planalto.gov.br/ccivil_03/leis/L9394.htm>. Acesso em 20 abr. 2016. 
Lei $n^{0}$ 10.172, que aprova o Plano Nacional de Educação. Brasília: Diário Oficial da União, 2001. Disponível em: <http://www.planalto.gov.br/ccivil_03/leis/L9394.htm>. Acesso em 20 set. 2016.

BROWN, T. Change by Design: How Design Thinking Transforms Organizations and Inspires Innovation, New York: Harper Business, 2009.

BROWN, T. Design Thinking. Rio de Janeiro: Elsevier, 2010.

BROWN JR., O. Participatory Ergonomics (PE). In: STANTON, N. A. (Ed.). Handbook of Human Factors and Ergonomics Methods. Boca Raton: CRC Press, 2005. p. 81-1-81-7.

BUCHANAN, R. Management and Design: Interaction Pathways in Organizational Life. In: BOLAND JR., R. J.; COLLOPY, F. (Eds.). Managing as Designing. Stanford: Stanford University Press, 2004. p. 54-64.

BUCHANAN, R. Worlds in the Making: Design, Management, and the Reform of Organizational Culture. Xangai: She Ji: The Journal of Design, Economics and Innovation, $2015 . \quad$ Disponível em: <http://www.sciencedirect.com/science/article/pii/S2405872615000039>. Acesso em 30 mar. 2016.

BÚRIGO, C. C. D. et al. A Gestão Colaborativa no processo formativo da EAD. Revista Gestão Universitária na América Latina - GUAL, v. 9, n. 1, p. 165176, 2016. Disponível em: $<$ https://periodicos.ufsc.br/index.php/gual/article/view/19834535.2016v9n1p165/31558>. Acesso em 25 out. 2016.

CALDAS, M. P.; FACHIN, R. Paradigma funcionalista: desenvolvimento de teorias e institucionalismo nos anos 1980 e 1990. RAE - Revista de Administração de Empresas, v. 45, n. 2, p. 46-51, 2005. Disponível em: <http://rae.fgv.br/rae/vol45-num2-2005>. Acesso em: 14 jun. 2017.

CÂNDIDO, R. et al. Método Delphi - uma ferramenta para uso em Microempresas de Base Tecnológica. Revista da FAE, v. 10, n. 2, p. 157-164, 2007. Disponível em: < https://revistafae.fae.edu/revistafae/article/view/346/242>. Acesso em: 20 out. 2017.

CARAYON, P.; HOONAKKER, P.; SMITH, M. J. Human Factors in Organizational Design and Management. In: SALVENDY, G. (Ed.). Handbook of Human Factors and Ergonomics. Hoboken: Wiley, 2012. p. 534-552.

CAVALCANTI, C. M. C. Contribuições do Design Thinking para concepção de interfaces de Ambientes Virtuais de Aprendizagem centradas no ser humano. 2015. 254f. Tese (Doutorado) - Universidade de São Paulo, Curso de PósGraduação em Educação.

CHIAVENATO, I. Gestão de pessoas: o novo papel dos recursos humanos nas organizações. Rio de Janeiro: Campus, 1999. 
CORIAT, B. Ciencia, técnica y capital. Madrid: H. Blume, 1976.

CORRÊA, D. A.; GONÇALVES, W. A.; SANTOS, A. L. L. Impactos do bônus demográfico para gestão de pessoas. Revista de Administração FACES Journal, v. $15, \quad$ n. $3, \quad$ p. 69-87, 2016. Disponível em: < http://www.spell.org.br/documentos/ver/42939/impactos-do-bonus-demograficopara-gestao-de-pessoas>. Acesso em 20 nov. 2016.

COURAGE, C.; BAXTER, K. Understanding Your Users: A Practical Guide to User Requirements Methods, Tools, and Techniques. San Francisco, CA: Elsevier, 2005.

COUTINHO, L. Aprendizagem on-line por meio de estruturas de cursos. In: LITTO, F. M.; FORMIGA, M. (Org.). Educação a distância : o estado da arte Volume 1. São Paulo: Pearson, 2009. p. 310-316.

CYBIS, W.; BETIOL, A. H.; FAUST, R. Ergonomia e Usabilidade: Conhecimentos, Métodos e Aplicações. São Paulo: Novatec Editora, 2007.

DALMORO, M.; VIEIRA, K. M. Dilemas na Construção de Escalas Tipo Likert: o Número de Itens e a Disposição Influenciam nos Resultados? Revista Gestão Organizacional, v. 6, n. 3, p. 161-174, 2013. Disponível em: <https://bell.unochapeco.edu.br/revistas/index.php/rgo/article/view/1386>. Acesso em 21 jul. 2017.

DEL GAUDIO, C. Design Participativo e Inovação Social: A influência dos fatores contextuais. 2014. 342f. Tese (Doutorado) - PUC-Rio, Curso de PósGraduação em Design.

DIAS, E. D. P. Conceitos de gestão e administração: Uma revisão crítica. REA Revista Eletrônica de Administração, v. 1, n. 1, p. 1-12, 2002. Disponível em: <http://periodicos.unifacef.com.br/index.php/rea/article/view/160/16>. Acesso em 22 nov. 2016.

DUL, J.; CEYLAN, C. Work environments for employee creativity. Loughborough: Ergonomics, 2010. Disponível em: <http://www.tandfonline.com/doi/abs/10.1080/00140139.2010.542833>. Acesso em 01 mai. 2016.

DEMARCHI, A. P. P.; FORNASIER, C. B. R.; MARTINS, R. F. F. A Gestão de Design humanizada pelo Design Thinking a partir de relações conceituais. Londrina: Revista Projética, 2011. Disponível em: <http://www.uel.br/revistas/uel/index.php/projetica/article/view/10108>. Acesso em 04 mai. 2016.

EVERling, M. T.; MONT'AlVÃO, C. Diretrizes Para um Ambiente de Aprendizagem Assíncrona no Curso de Design. 2011. 411f. Tese (Doutorado) PUC-Rio, Curso de Pós-Graduação em Design.

FACHIN, O. Fundamentos de metodologia. São Paulo: Saraiva, 2003. 
FARIAS, S. C. Os benefícios das Tecnologias de Informação e Comunicação (TIC) no processo de Educação a Distância (EAD). Revista Digital de Biblioteconomia e Ciência da Informação, v. 11, n. 3, p. 15-29, 2013. Disponível em: <http://periodicos.sbu.unicamp.br/ojs/index.php/rdbci/issue/view/147/showToc>. Acesso em 02 out. 2016.

FIRMINO, D. L. F.; VIEIRA, J. J. Consórcio CEDERJ: uma análise crítica. Anais do 3o Seminário Internacional Inclusão em Educação: Universidade e Participação. Anais... Rio de Janeiro: UFRJ, 2013. Disponível em: <http://www.lapeade.educacao.ufrj.br/anais/files/WSM31A54.pdf>. Acesso em 21 ago. 2017.

FORMIGA, M. A terminologia da EAD. In: LITTO, F. M.; FORMIGA, M. (Org.). Educação a distância : o estado da arte - Volume 1. São Paulo: Pearson, 2009. p. 39-46.

GAMEZ, L. A estruturação de cursos em EAD. In: LITTO, F. M.; FORMIGA, M. (Org.). Educação a distância : o estado da arte - Volume 2. São Paulo: Pearson, 2012. p. 75-82.

GIL, A. C. Como elaborar projetos de pesquisa. São Paulo: Atlas, 2002.

GOMES, C. A. DA C. A legislação que trata da EAD. In: LITTO, F. M.; FORMIGA, M. (Org.).Educação a distância : o estado da arte - Volume 1. São Paulo: Pearson, 2009. p. 21-28.

GOMES, L. F. EAD no Brasil: perspectivas e desafios. Campinas: Avaliação: Revista da Avaliação da Educação Superior, 2013. Disponível em: $<$ http://www.scielo.br/scielo.php?script=sci_arttext\&pid=S1414$40772013000100002 \& \operatorname{lng}=$ pt\&nrm=iso > . Acesso em 20 abr. 2016.

HENDRICK, H. W. Macroergonomic Methods. In: STANTON, N. A. (Ed.). Handbook of Human Factors and Ergonomics Methods. Boca Raton: CRC Press, 2005. p. 75-1-75-4.

HENDRICK, H. W.; KLEINER, B. M. Macroergonomics: An Introduction to Work System Design. Santa Monica (CA): Human Factors and Ergonomics Society, 2001.

Jersey: CRC Press, 2002.

Macro ergonomics: Theory, Methods, and Applications. New

HOLLAND, R.; LAM, B. Managing Strategic Design. Nova Iorque: Palgrave, 2014.

KALLEBERG, A. L. Precarious work, insecure workers: employment relations in transition. American Sociological Review, v. 74, n. 1, p. 1-22, 2013. Disponível em: <http://www.jstor.org/stable/27736045>. Acesso em: 29 out. 2016. 
KLEINER, B. M. Macroegonomics: work system analysis and design. Human

factors, v. 50, n. 3, p. 461-467, 2008. Disponível em: <http://journals.sagepub.com/doi/abs/10.1518/001872008X288501>. Acesso em: 07 de jun. de 2017.

KLEINER, B. M.; HENDRICK, H. W. Human factors in organizational design and management of industrial plants. International Journal of Technology and Human Interaction 4.1, 2008. Disponível em: <http://go.galegroup.com/ps/i.do?id=GALE\%7CA172437275\&amp;v=2.1\&amp; $\mathrm{u}=$ capes \&amp;it=r\&amp;p=AONE\&amp;sw=w\&amp;a sid=9abfb82c741421dc160a24ae2ea812a5> . Acesso em 15 abr. 2016.

LAKATOS, E.M., MARCONI, M. de A. Fundamentos de metodologia científica. 5.ed. São Paulo: Atlas, 2003.

LANA, R. D. et al. As organizações como fonte de conflitos de poder. Revista Administração UFSM, v. 9, n. 3, p. 506-519, 2016. Disponível em: < https://periodicos.ufsm.br/reaufsm/article/view/10055>. Acesso em 25 nov. 2016.

LEÃO, L. H. D. C. Psicologia do Trabalho: aspectos históricos, abordagens e desafios atuais. Ecos, v. 2, n. 2, p. 291-305, 2012. Disponível em: <http://www.uff.br/periodicoshumanas/index.php/ecos/article/view/1008>. Acesso em 22 out. 2016.

LITTO, F M. O atual cenário internacional da EAD. In: LITTO, F. M.; FORMIGA, M. (Org.). Educação a distância : o estado da arte - Volume 1. São Paulo: Pearson, 2009. p. 14-20.

LONGO, C. R. J. A EAD na pós-graduação. In: LITTO, F. M.; FORMIGA, M. (Org.). Educação a distância: o estado da arte - Volume 1. São Paulo: Pearson, 2009. p. 215-222.

MALLMANN, E. M.; CATAPAN, A. H. Materiais Didáticos em Educação a Distância: gestão e mediação pedagógica. Linhas, v. 8, n. 2, p. 63-75, 2007. Disponível

em: <http://www.periodicos.udesc.br/index.php/linhas/article/view/1360>. Acesso em 23 jun. 2016.

MATTAR, J. Interatividade e aprendizagem. In: LITTO, F. M.; FORMIGA, M. (Org.). Educação a distância: o estado da arte - Volume 1. São Paulo: Pearson, 2009. p. 112-120.

MAXIMIANO, A. C. A. Teoria geral da administração: da revolução urbana à revolução digital. São Paulo: Atlas, 2010.

MEDEIROS, M. I. G. et al. Estrutura Organizacional E Modelo De Gestão: Uma Análise No Instituto Federal Sul-Rio-Grandense - Ifsul. II Congresso Internacional IGLU. Anais... Florianópolis: 2011. Disponível em: $<$ https://repositorio.ufsc.br/bitstream/handle/123456789/26140/5.34.pdf?sequence =1>. Acesso em 22 nov. 2016. 
MOORE, M.; KEARSLEY, G. Educação a distância: uma visão integrada. São Paulo: Thompson Learning, 2007.

MORAES, A. DE. Ergonomia, ergodesign e usabilidade: algumas histórias, precursores: divergências e convergências. Ergodesign e HCI, v. 1, n. 1, p. 1-9, 2013. Disponível em: <http://ergodesign-hci.com.br/artigos/artigo_01_v-1_n1_ano_1.pdf $>$. Acesso em 22 jun. 2016.

MORAES, R. Análise de conteúdo. Revista Educação, v. 22, n. 37, p. 7-32, 1999.

MORAN, J.; VALENTE, J.; ARANTES, V. (org.). Educação a Distância: Pontos e Contrapontos. São Paulo: Summus Editorial, 2011.

MORAN, J. A EAD no Brasil: cenário atual e caminhos viáveis de mudança. Disponível em: <http://www2.eca.usp.br/moran/wpcontent/uploads/2013/12/cenario.pdf>. Acesso em 02 out. 2016.

Desafios da educação a distância no Brasil. Revista RCN, v. 12, p.

14-16, 2012. Disponível em: <http://www2.eca.usp.br/moran/wpcontent/uploads/2013/12/desafios_ead.pdf>. Acesso em 02 out. 2016.

MORAES NETO, B. R. DE. Maquinaria, Taylorismo e Fordismo: a Reinvenção da Manufatura. RAE-Revista de Administração de Empresas, v. 26, n. 4, 1986. Disponível em: <http://rae.fgv.br/rae/vol26-num4-1986/maquinaria-taylorismofordismo-reinvencao-manufatura $>$. Acesso em 26 out. 2016.

MOREIRA, M. A composição e o funcionamento da equipe de produção. In: LITTO, F. M.; FORMIGA, M. (Org.). Educação a distância : o estado da arte Volume 1. São Paulo: Pearson, 2009. p. 370-378.

MOURA, A. L. P. Métodos e técnicas de Design Centrado no Usuário: um levantamento a partir da usabilidade de produtos do CTIC/Fiocruz. 2015. 292 f. Dissertação (mestrado) - UERJ, Curso de Pós-Graduação em Design.

MOZOTA, B. Gestão do design - usando o design para construir valor de marca e inovação corporativa. Porto Alegre: Bookman, 2011.

MUGNOL, M. Educação a Distância no Brasil: conceitos e fundamentos. Curitiba: Revista Diálogo Educacional, 2009. Disponível em: $<$ http://google.redalyc.org/articulo.oa?id=189117298008>. Acesso em 20 abr. 2016.

NAGUEL, M.; DENCK, R. Série técnica: manual de psicologia organizacional. 21. ed. Curitiba: Unificado, 2007.

NAVARRO, V. L.; PADILHA, V. Dilemas do Trabalho no Capitalismo Contemporâneo. Psicologia \& Sociedade, Edição Especial n. 1, p. 14-20, 2007. Disponível <http://www.ufrgs.br/seerpsicsoc/ojs2/index.php/seerpsicsoc/article/viewFile/266 4/1601>. Acesso em 29 out. 2016. 
NISKIER, A. Educação a distância: a tecnologia da esperança. São Paulo: Loyola, 2000.

NORDESTE, D. DO. Brasil é o 60 em uso de smartphones no mundo; na América Latina o País é o líder. Disponível em: $<$ http://diariodonordeste.verdesmares.com.br/suplementos/tecno/online/brasil-e-o6-em-uso-de-smartphones-no-mundo-na-america-latina-o-pais-e-o-lider1.1190571>. Acesso em 02 out. 2016.

NUNES, I. B. A história da EAD no mundo. In: LITTO, F. M.; FORMIGA, M. (Org.). Educação a distância : o estado da arte - Volume 1. São Paulo: Pearson, 2009. p. 2-8.

NUNES, R. DA S. et al. A experiência sócio-técnica no ambiente de produção: uma discussão acerca do Volvismo. Revista de Administração UFSM, v. 2, n. 2, p. 235-249, 2009. Disponível em: <https://periodicos.ufsm.br/reaufsm/article/view/1554>. Acesso em: 30 out. 2016.

NUNES, L.; MONT'ALVÃO, C. Visualização do invisível: valores humanos no design de sistemas de eco-feedback para a reciclagem de resíduos sólidos urbanos. 2017. 253f. Dissertação (Mestrado) - PUC-Rio, Curso de PósGraduação em Design.

O GLOBO. Usuários de internet móvel no Brasil crescem $7 \%$ nos últimos seis meses e chegam a $\mathbf{3 8 , 3}$ milhões. Disponível em: $<$ http://oglobo.globo.com/sociedade/tecnologia/usuarios-de-internet-movel-nobrasil-crescem-7-nos-ultimos-seis-meses-chegam-383-milhoes-16195120>. Acesso em: 4 out. 2016.

Relembre a crise econômica e política no estado do Rio. Disponível em: <https://infograficos.oglobo.globo.com/rio/linha-do-tempo-da-crise-norio.html\#7>. Acesso em 21 set. 2017.

OLIVEIRA, D. S. DE. O uso do vídeo em EAD: desafios no processo de ensino aprendizagem. Revista Cesuca Virtual: Conhecimento sem Fronteiras, v. 1, n. 1, p. 1-15, 2013. Disponível em: <http://ojs.cesuca.edu.br/index.php/cesucavirtual/article/view/422>. Acesso em: 12 jul. 2016.

OTONI, A. C. Brasileiros gastam 650 horas por mês em redes sociais. Disponível em: <http://blogs.oglobo.globo.com/nas-redes/post/brasileiros-gastam-650horas-por-mes-em-redes-sociais-567026.html>. Acesso em: 4 out. 2016.

PALANGE, I. Os métodos de preparação de material para cursos on-line. In: LITTO, F. M.; FORMIGA, M. (Org.). Educação a distância : o estado da arte Volume 1. São Paulo: Pearson, 2009. p. 379-385. 
PEW, R. W.; MAVOR, A. S. Human-System Integration in the System Development Process: A New Look. Washington: The National Academies Press, 2007.

RAUPP, F. M.; BEUREN, I. M. Modelos de gestão flexíveis a partir de mudanças na cultura organizacional alicerçada no empreendedorismo. Revista de Ciências da Administração, v. 5, n. 10, p. 1-18, 2003. Disponível em: <https://periodicos.ufsc.br/index.php/adm/article/view/1782>. Acesso em 25 out. 2016.

RIO DE JANEIRO. Lei Complementar $n^{0}$ 103, que transforma o Centro de Ciências do Estado do Rio de Janeiro na Fundação Centro de Ciências e Educação Superior à Distância do Estado do Rio de Janeiro - Fundação CECIERJ. Rio de Janeiro: Diário Oficial do Estado do Rio de Janeiro, 2002.

SANTOS, N. DE M. et al. Cultura Organizacional, Estrutura Organizacional e Gestão de Pessoas como Bases para uma Gestão Orientada por Processos e seus Impactos no Desempenho Organizacional. Brazilian Business Review (Portuguese Edition), v. 11, n. 3, p. 106-129, 2014. Disponível em: $<$ http://www.scielo.br/scielo.php?pid=S0080-

$21072013000100004 \&$ script=sci_abstract\&tlng=pt $>$. Acesso em 23 nov. 2016.

SARAIVA, T. Educação a distância no Brasil: lições da história. Em Aberto, v. 16, n. 70, abr./jun., p. 17-27, 1996. Disponível em: <http://www.rbep.inep.gov.br/index.php/emaberto/article/viewFile/1048/950>. Acesso em 04 jun. 2016.

SILVA, A. H.; FOSSÁ, M. I. T. Análise de Conteúdo: Exemplo de Aplicação da Técnica para Análise de Dados Qualitativos. EnEPQ 2013, p. 1-14, 2013.

SILVA, N. A. N. Abordagens Participativas para o Design: Metodologias e plataformas sociotécnicas como suporte ao design interdisciplinar e aberto a participação. 2012. 67 f. Dissertação (Mestrado) - PUC-SP, Curso de PósGraduação em Tecnologias da Inteligência e Design Digital.

SILVA, L. A.; SANTOS, J. N. Concepções e Práticas do Trabalho e da Gestão de Equipes Multidisciplinares na Saúde. Revista de Ciências da Administração, v. 14, n. 34, p. 155-168, 2012. Disponível em: <http://spell.org.br/documentos/ver/9070/concepcoes-e-praticas-do-trabalho-egestao-de-equipes-multidisciplinares-em-saude>. Acesso em 30 nov. 2016.

SMITH, M. J.; CARAYON-SAINFORT, P. A balance theory of job design for stress reduction. International Journal of Industrial Ergonomics, v. 4, n. 1, p. 6779, $1989 . \quad$ Disponível em: <http://www.sciencedirect.com/science/article/pii/0169814189900516\#>. Acesso em 20 ago. 2016.

TEIXEIRA, O. A. F.; WESCHENFELDER, G. V. Evolução do EAD e as novas mídias. Revista Cesuca Virtual: Conhecimento sem Fronteiras, v. 1, n. 1, p. 121, 2013. Disponível em: 
$\langle$ http://ojs.cesuca.edu.br/index.php/cesucavirtual/article/view/425/210>. Acesso em 26 jun. 2016.

TROIAN, T. A. Service Design como meio de inovação em organizações prestadoras de serviço: caso do hospital Moinhos de Vento. Porto Alegre: CRARSRS, 2013. Disponível em: <http://crars.org.br/artigos_interna/service-designcomo-meio-de-inovacao-em-organizacoes-prestadoras-de-servicos-caso-dohospital-moinhos-de-vento- 44.html>. Acesso em 04 jul. 2015.

TROJAN, R. M.; SIPRAKI, R. Perspectivas de estudos comparados a partir da aplicação da Escala Likert de 4 pontos: um estudo metodológico da pesquisa TALIS. Revista Ibero-Americana de Estudos em Educação, v. 10, n. 2, p. 275300, 2015. Disponível em: $<$ http://seer.fclar.unesp.br/iberoamericana/article/view/7761>. Acesso em 16 ago. 2017.

VALLA, D. F.; FERREIRA, M. S. Investigando o Centro de Ciências do Estado da Guanabara e suas retóricas nos anos de 1960/70. Atas do VI Encontro Nacional de Pesquisa em Educação em Ciências. Anais... Belo Horizonte: ABRAPEC, $2007 . \quad$ Disponível em: <http://www.nutes.ufrj.br/abrapec/vienpec/CR2/p656.pdf>. Acesso em 19 ago. 2017.

WALKER, G. H. et al. A review of sociotechnical systems theory: a classic concept for new command and control paradigms. Theoretical Issues in Ergonomics Science, v. 9, n. 6, p. 1-49, 2008. Disponível em: <http://www.tandfonline.com/doi/abs/10.1080/14639220701635470>. Acesso em 02 ago. 2017.

WATSON, J. et al. Macroergonomics in Education: On Your Mark, Set, GO! Proceedings of the Human Factors and Ergonomics Society Annual Meeting. Anais...1 out. 2009. Disponível em: 〈http://hfs.sagepub.com/content/50/3/461>. Acesso em 20 jun. 2016.

WOOD JR., T. Fordismo, toyotismo e volvismo: os caminhos da indústria em busca do tempo perdido. Revista de Administração de Empresas, v. 32, n. 4, p. 6-18, 1992. Disponível em: <http://spell.org.br/documentos/ver/14858/fordismo-toyotismo-e-volvismo--os-caminhos-da-industria-em-busca-do-tempoperdido/i/pt-br>. Acesso em 27 out. 2016.

YIN, R. Estudo de caso: planejamento e métodos. Porto Alegre: Bookman, 2001. 


\section{Anexos}

\section{Anexo I - Parecer positivo do Comitê de Ética da PUC-Rio para} a realização desta pesquisa
Pontifícia Universidade Católica

DO RIO DE JANEIRO

Câmara de Ética em Pesquisa da PUC - Rio

PARECER DA COMISSÃO DE ÉTICA EM PESQUISA DA PUC-RIO (2017-61)

A Câmara de Ética em Pesquisa da PUC-Rio foi constituída como uma Câmara específica do Conselho de Ensino e Pesquisa conforme decisão deste órgão colegiado com atribuição de avaliar projetos de pesquisa do ponto de vista de suas implicações éticas.

Identificação:

Título: $O$ designer como agente organizocional na produção multidisciplinar de material didático para EAD (Departamento de Artes \& Design da PUC-Rio)

Autor: Cid Moreira Boechat (Mestrando do Departamento de Artes \& Design da PUC-Rio)

Orientadora: Claudia Renata Mont'Alvão (Professora do Departamento de Artes \& Design da PUC-Rio)

Apresentação: A pesquisa tem a ver com o uso do Design e da Ergonomia como ferramentas de gestão $e$ resoluçäo de problemas em ambientes multidisciplinares de EAD (Educação a Distância), aplicados em sistemas de trabalho para a resoluç̧o de questões organizacionais enfrentadas pelas instituiçães de ensino superior. Ten conto objetivo construir, com os atores envolvidos, propostes de gesto e de aperfeiconento de processes de funcion (Fundaç̃os Centro de Eduçăo Distâncio do Estodo do Rio ferracta didático para EAD. para EAD.

Aspectos éticos: $O$ projeto e os Termos de Consentimento Livre e Esclarecido (entrevista e questionário) apresentados estão de acordo com os princípios e valores do Marco Referencial, Estatuto e Regimento do Universidade no que se referem às responsabilidades de seu corpo docente e discente. Os Termos de Consentimento Livre e Esclarecido expöem com clareza os objetivos da pesquisa, os procedimentos a serem seguidos $e$ a garantia do sigilo e da confidencialidade dos dados coletados e da identidade dos participantes. Informam sobre a possibilidade de interrupção na pesquisa sem aplicação de qualquer penalidade ou constrangimento.

Parecer: Considerando os elementos expostos acima somos de parecer Favorável d̀ aprovação do projeto quento cos princípios e critérios estabelecidos pela Comissão de Ética em Pesquisa da PUC-Rio.

Prof. José Ricuddo Bergmann

Presidente do Conselho de Ensino e Pesquisa da PUC-Rio 


\section{Apêndices}

Apêndice I - Termo de consentimento para entrevista estruturada

\section{TERMO DE CONSENTIMENTO LIVRE E ESCLARECIDO}

Pontifícia Universidade Católica do Rio de Janeiro

Programa de Pós-Graduação em Design | PPGDesign PUC-Rio

Pesquisador Responsável: Claudia Mont'Alvão |E-mail: cmontalvao@puc-rio.br

Assistentes de pesquisa: Cid Boechat

E-mails: cmontalvao@puc-rio.br ou ergonomiapuc@gmail.com

O Sr. (a) está sendo convidado (a) como voluntário (a) a participar da pesquisa "Perguntas sobre seu cotidiano de trabalho na Fundação Cecierj". Esta é uma pesquisa realizada pelo Laboratório de Ergodesign e Usabilidade de Interfaces da PUC-Rio.

Qualquer dúvida a respeito dos procedimentos, dos resultados e/ou de assuntos relacionados à pesquisa será esclarecida pelo aluno pesquisador Cid Boechat e/ou por sua orientadora Cláudia Mont'Alvão, no telefone (21) 99361-0491 ou através dos e-mails: cmontalvao@puc-rio.br ou ergonomiapuc@gmail.com.
O objetivo da pesquisa é obter um levantamento sobre o cotidiano de trabalho da equipe multidisciplinar que produz material didático da Fundação Cecierj.

Para este estudo adotaremos o seguinte procedimento em 1 (UMA etapa) que consiste em uma entrevista estruturada onde será utilizado um gravador de áudio e seu depoimento poderá ser utilizado para fins científicos e de estudos.

BENEFÍCIOS: A presente pesquisa busca contribuir para melhorar o sistema de trabalho em equipes que produzem material didático para $\mathrm{EaD}$ através de metodologias de Design.

RISCOS: por se tratar de uma metodologia cuja técnica pauta-se em uma entrevista e levantamento de dados demográficos, a mesma é considerada com possibilidade quase nula de riscos para o entrevistado. OS ENTREVISTADOS NÃO SERÃO IDENTIFICADOS NA PESQUISA NEM TERÃO SEUS NOMES LIGADOS AOS SEUS DEPOIMENTOS.

RESSARCIMENTO: Os voluntários dessa pesquisa não serão remunerados por essa participação e nem tampouco correrão riscos. Para participar deste estudo você não terá nenhum custo, nem receberá qualquer vantagem financeira. Você será esclarecido sobre o estudo em qualquer aspecto que desejar e estará livre para participar ou recusar-se a participar. Poderá retirar seu consentimento ou interromper a participação a qualquer momento. A sua participação é voluntária e a recusa em participar não acarretará qualquer penalidade ou modificação na forma em que é atendido pelo pesquisador. 


\section{A PRESENTE PESQUISA NÃO TEM QUALQUER LIGACÃO COM A FUNDAÇÃO CECIERJ OU OUTRO ÓRGÃO GOVERNAMENTAL.}

Depois de conhecer e entender os objetivos, procedimentos metodológicos, riscos e benefícios da pesquisa, bem como de estar ciente da necessidade do uso do meu depoimento, especificados nesse Termo de Consentimento Livre e Esclarecido (TCLE), AUTORIZO, através do presente termo, os pesquisadores Cid Boechat e sua orientadora Cláudia Mont'Alvão, do projeto de pesquisa intitulado " $\underline{O}$ Design e a Ergonomia como ferramentas organizacionais na producão multidisciplinar de material didático para EAD" (título provisório), a colher meu depoimento sem quaisquer ônus financeiros a nenhuma das partes.

Ao mesmo tempo, libero a utilização destes depoimentos para fins científicos e de estudos (livros, artigos, slides e transparências), em favor dos pesquisadores da pesquisa, acima especificados.

$\mathrm{O}$ pesquisador irá tratar a sua identidade com padrões profissionais de sigilo. Os resultados da pesquisa estarão à sua disposição quando finalizada. Seu nome ou o material que indique sua participação não será liberado sem a sua permissão.

O (A) Sr. (a) não será identificado em nenhuma publicação que possa resultar deste estudo.

Agradeço, desde já, pela sua atenção e valiosa colaboração!

Cid Boechat - cidboechat@gmail.com

De acordo,

Assinatura do participante 
Apêndice II - Contagem de ocorrências da análise de conteúdo,

divididas por categorias

\begin{tabular}{|c|c|c|c|c|c|c|c|c|c|c|c|c|c|c|c|c|}
\hline \multicolumn{3}{|c|}{ Categoria e Unidades } & \multicolumn{12}{|c|}{ Contagem das ocorrências por questão da entrevista } & \multicolumn{2}{|c|}{ Total e norcentagem } \\
\hline \multirow[t]{8}{*}{ Categoria 1} & U. Contexto & U. Registro & Q1 & Q2 & Q3 & Q4 & Q5 & Q6 & Q7 & Q8 & Q9 & Q10 & Q11 & Q12 & Total de ocorrências & $\%$ sobre o total de ocorrências \\
\hline & \multirow{3}{*}{1.1} & 1.1 .1 & 0 & 0 & 1 & 0 & 0 & 0 & 0 & 0 & 0 & 0 & 0 & 0 & 1 & 8,33 \\
\hline & & 1.1 .2 & 0 & 0 & 3 & 0 & 0 & 0 & 0 & 0 & 0 & 0 & 0 & 0 & 3 & 25 \\
\hline & & 1.1 .3 & 0 & 0 & 0 & 0 & 0 & 0 & 0 & 0 & 0 & 0 & 0 & 1 & 1 & 8,33 \\
\hline & 1.2 & 1.2 .1 & 0 & 0 & 0 & 0 & 0 & 0 & 0 & 1 & 0 & 0 & 0 & 0 & 1 & 8,33 \\
\hline & \multirow[t]{2}{*}{1.3} & 1.3.1 & 0 & 0 & 0 & 1 & 0 & 0 & 0 & 0 & 0 & 0 & 2 & 1 & 4 & 33,33 \\
\hline & & 1.3 .2 & 0 & 0 & 0 & 0 & 0 & 0 & 0 & 0 & 0 & 0 & 2 & 0 & $\frac{7}{2}$ & 16,66 \\
\hline & & & & & OTA & DA & ATEC & DRIA & & & & & & & 12 & $100 \%$ \\
\hline
\end{tabular}

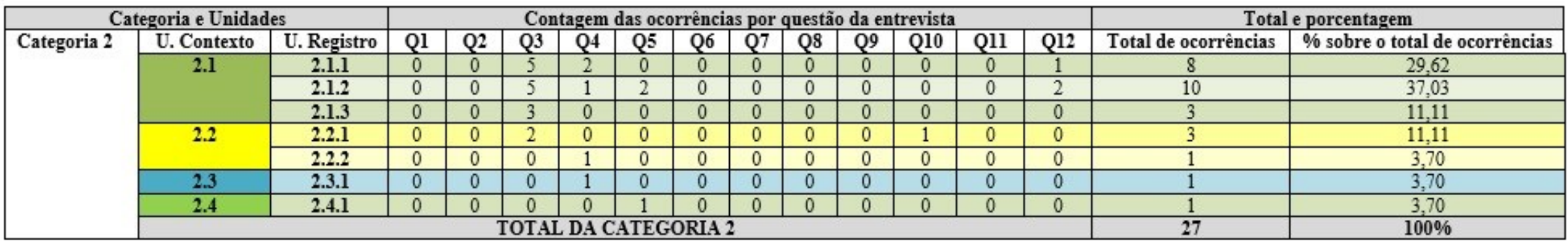




\begin{tabular}{|c|c|c|c|c|c|c|c|c|c|c|c|c|c|c|c|c|}
\hline \multicolumn{3}{|c|}{ Categoria e Unidades } & \multicolumn{12}{|c|}{ Contagem das ocorrências por questão da entrevista } & \multicolumn{2}{|c|}{ Total e porcentagem } \\
\hline \multirow[t]{20}{*}{ Categoria 3} & U. Contexto & U. Registro & Q1 & Q2 & Q3 & Q4 & Q5 & Q6 & Q7 & Q8 & Q9 & Q10 & Q11 & Q12 & Total de ocorrências & $\%$ sobre o total de ocorrèncias \\
\hline & \multirow[t]{3}{*}{3.1} & 3.1 .1 & 0 & 0 & 3 & 1 & 1 & 2 & 0 & 1 & 6 & 0 & 0 & 0 & 14 & 11,29 \\
\hline & & 3.1 .2 & 0 & 0 & 0 & 1 & 0 & 0 & 1 & 2 & 0 & 0 & 0 & 0 & 4 & 3,22 \\
\hline & & 3.1 .3 & 0 & 0 & 0 & 0 & 1 & 0 & 0 & 0 & 2 & 0 & 0 & 0 & 3 & 2,41 \\
\hline & \multirow[t]{2}{*}{3.2} & 3.2.1 & 0 & 0 & 1 & 2 & 6 & 9 & 14 & 4 & 9 & 3 & 0 & 0 & 48 & 38,7 \\
\hline & & 3.2 .2 & 0 & 0 & 0 & 1 & 2 & 0 & 0 & 1 & 0 & 1 & 0 & 0 & 5 & 4.03 \\
\hline & \multirow[t]{4}{*}{3.3} & 3.3 .1 & 0 & 0 & 1 & 2 & 0 & 0 & 0 & 0 & 0 & 0 & 0 & 0 & 3 & 2,41 \\
\hline & & 3.3 .2 & 0 & 0 & 0 & 0 & 1 & 0 & 0 & 0 & 0 & 0 & 0 & 0 & 1 & 0,80 \\
\hline & & 3.3 .3 & 0 & 0 & 0 & 0 & 2 & 0 & 0 & 0 & 0 & 0 & 0 & 0 & 2 & 1,61 \\
\hline & & 3.3 .4 & 0 & 0 & 0 & 0 & 1 & 0 & 0 & 0 & 0 & 0 & 0 & 0 & 1 & 0,80 \\
\hline & \multirow[t]{3}{*}{3.4} & 3.4 .1 & 0 & 0 & 0 & 5 & 0 & 0 & 0 & 0 & 0 & 0 & 0 & 0 & 5 & 4,03 \\
\hline & & 3.4 .2 & 0 & 0 & 0 & 2 & 2 & 0 & 1 & 0 & 1 & 0 & 0 & 1 & 7 & 5,64 \\
\hline & & 3.4 .3 & 0 & 0 & 0 & 2 & 4 & 0 & 0 & 0 & 5 & 1 & 0 & 1 & 13 & 10,48 \\
\hline & \multirow[t]{2}{*}{3.5} & 3.5 .1 & 0 & 0 & 0 & 0 & 0 & 9 & 4 & 0 & 0 & 0 & 0 & 0 & 13 & 10,48 \\
\hline & & 3.5 .2 & 0 & 0 & 0 & 0 & 0 & 0 & 1 & 0 & 0 & 0 & 0 & 0 & 1 & 0,80 \\
\hline & \multirow[t]{4}{*}{3.6} & 3.6 .1 & 0 & 0 & 0 & 0 & 0 & 0 & 0 & 0 & 0 & 0 & 1 & 0 & 1 & 0,80 \\
\hline & & 3.6 .2 & 0 & 0 & 0 & 0 & 0 & 0 & 0 & 0 & 0 & 1 & 0 & 0 & 1 & 0,80 \\
\hline & & 3.6 .3 & 0 & 0 & 0 & 0 & 0 & 0 & 0 & 0 & 1 & 0 & 0 & 0 & 1 & 0,80 \\
\hline & & 3.6 .4 & 0 & 0 & 0 & 0 & 0 & 0 & 0 & 0 & 1 & 0 & 0 & 0 & 1 & 0,80 \\
\hline & \multicolumn{14}{|c|}{ TOTAL DA CATEGORIA 3} & 124 & $100 \%$ \\
\hline
\end{tabular}




\begin{tabular}{|c|c|c|c|c|c|c|c|c|c|c|c|c|c|c|c|c|}
\hline \multicolumn{3}{|c|}{ Categoria e Unidades } & \multicolumn{12}{|c|}{ Contagem das ocorrências por questão da entrevista } & \multicolumn{2}{|c|}{ Total e porcentagem } \\
\hline \multirow[t]{31}{*}{ Categoria 4} & U. Contexto & U. Registro & Q1 & Q2 & Q3 & Q4 & Q5 & Q6 & Q7 & Q8 & Q9 & Q10 & Q11 & Q12 & Total de ocorrências & $\%$ sobre o total de ocorrências \\
\hline & \multirow[t]{9}{*}{4.1} & 4.1 .1 & 0 & 0 & 1 & 3 & 1 & 1 & 0 & 3 & 1 & 1 & 0 & 0 & 11 & 13,09 \\
\hline & & 4.1.2 & 0 & 0 & 0 & 2 & 1 & 1 & 0 & 0 & 1 & 3 & 0 & 2 & 10 & 11,90 \\
\hline & & 4.1 .3 & 0 & 0 & 1 & 6 & 1 & 1 & 0 & 0 & 0 & 0 & 0 & 0 & 9 & 10,71 \\
\hline & & 4.1 .4 & 0 & 0 & 0 & 0 & 3 & 0 & 0 & 3 & 1 & 0 & 0 & 1 & 8 & 9,52 \\
\hline & & 4.1 .5 & 0 & 0 & 0 & 1 & 1 & 0 & 0 & 0 & 0 & 0 & 1 & 0 & 3 & 3,57 \\
\hline & & 4.1 .6 & 0 & 0 & 0 & 0 & 0 & 0 & 1 & 0 & 0 & 1 & 0 & 1 & 3 & 3,57 \\
\hline & & 4.1 .7 & 0 & 0 & 0 & 0 & 1 & 0 & 0 & 0 & 0 & 0 & 0 & 0 & 1 & 1,19 \\
\hline & & 4.1 .8 & 0 & 0 & 0 & 0 & 0 & 0 & 0 & 0 & 1 & 0 & 0 & 0 & 1 & 1,19 \\
\hline & & 4.1 .9 & 0 & 0 & 0 & 0 & 0 & 0 & 0 & 0 & 1 & 0 & 0 & 0 & 1 & 1,19 \\
\hline & \multirow[t]{6}{*}{4.2} & 4.2 .1 & 0 & 0 & 0 & 2 & 0 & 0 & 0 & 0 & 0 & 0 & 0 & 3 & 5 & 5,95 \\
\hline & & 4.2 .2 & 0 & 0 & 0 & 1 & 0 & 0 & 1 & 0 & 0 & 0 & 0 & 0 & 2 & 2,38 \\
\hline & & 4.2 .3 & 0 & 0 & 0 & 1 & 0 & 0 & 0 & 0 & 0 & 0 & 0 & 1 & 2 & 2,38 \\
\hline & & 4.2 .4 & 0 & 0 & 0 & 0 & 0 & 0 & 2 & 0 & 0 & 0 & 0 & 0 & 2 & 2,38 \\
\hline & & 4.2 .5 & 0 & 0 & 0 & 0 & 0 & 0 & 0 & 1 & 0 & 0 & 0 & 1 & 2 & 2,38 \\
\hline & & 4.2 .6 & 0 & 0 & 0 & 1 & 0 & 0 & 0 & 0 & 0 & 0 & 0 & 0 & 1 & 1,19 \\
\hline & \multirow[t]{3}{*}{4.3} & 4.3 .1 & 0 & 0 & 0 & 2 & 0 & 0 & 0 & 0 & 2 & 1 & 0 & 0 & 5 & 5,95 \\
\hline & & 4.3 .2 & 0 & 0 & 0 & 0 & 1 & 0 & 0 & 0 & 0 & 0 & 0 & 0 & 1 & 1,19 \\
\hline & & 4.3 .3 & 0 & 0 & 0 & 0 & 1 & 0 & 0 & 0 & 0 & 0 & 0 & 0 & 1 & 1,19 \\
\hline & \multirow[t]{3}{*}{4.4} & 4.4.1 & 0 & 0 & 0 & 3 & 1 & 0 & 0 & 0 & 0 & 0 & 0 & 0 & 4 & 4,76 \\
\hline & & 4.4 .2 & 0 & 0 & 0 & 1 & 0 & 0 & 0 & 0 & 0 & 0 & 0 & 0 & 1 & 1,19 \\
\hline & & 4.4 .3 & 0 & 0 & 0 & 1 & 1 & 0 & 0 & 0 & 0 & 0 & 0 & 0 & 2 & 2,38 \\
\hline & \multirow[t]{4}{*}{4.5} & 4.5 .1 & 0 & 0 & 0 & 1 & 0 & 0 & 0 & 0 & 0 & 0 & 0 & 0 & 1 & 1,19 \\
\hline & & 4.5 .2 & 0 & 0 & 0 & 1 & 0 & 0 & 0 & 0 & 0 & 0 & 0 & 0 & 1 & 1,19 \\
\hline & & 4.5 .3 & 0 & 0 & 0 & 0 & 0 & 0 & 0 & 0 & 0 & 1 & 0 & 0 & 1 & 1,19 \\
\hline & & 4.5 .4 & 0 & 0 & 0 & 0 & 0 & 0 & 0 & 0 & 0 & 0 & 0 & 1 & 1 & 1,19 \\
\hline & \multirow[t]{2}{*}{4.6} & 4.6 .1 & 0 & 0 & 1 & 0 & 0 & 0 & 0 & 0 & 0 & 0 & 0 & 0 & 1 & 1,19 \\
\hline & & 4.6 .2 & 0 & 0 & 0 & 0 & 0 & 0 & 0 & 0 & 0 & 0 & 0 & 1 & 1 & 1,19 \\
\hline & \multirow[t]{2}{*}{4.7} & $\begin{array}{l}4.7 .1 \\
\end{array}$ & 0 & 0 & 1 & 0 & 1 & 0 & 0 & 0 & 0 & 0 & 0 & 0 & 2 & 2,38 \\
\hline & & 4.7 .2 & 0 & 0 & 0 & 0 & 1 & 0 & 0 & 0 & 0 & 0 & 0 & 0 & 1 & 1,19 \\
\hline & \multicolumn{14}{|c|}{ TOTAL DA CATEGORIA 4} & 84 & $100 \%$ \\
\hline
\end{tabular}




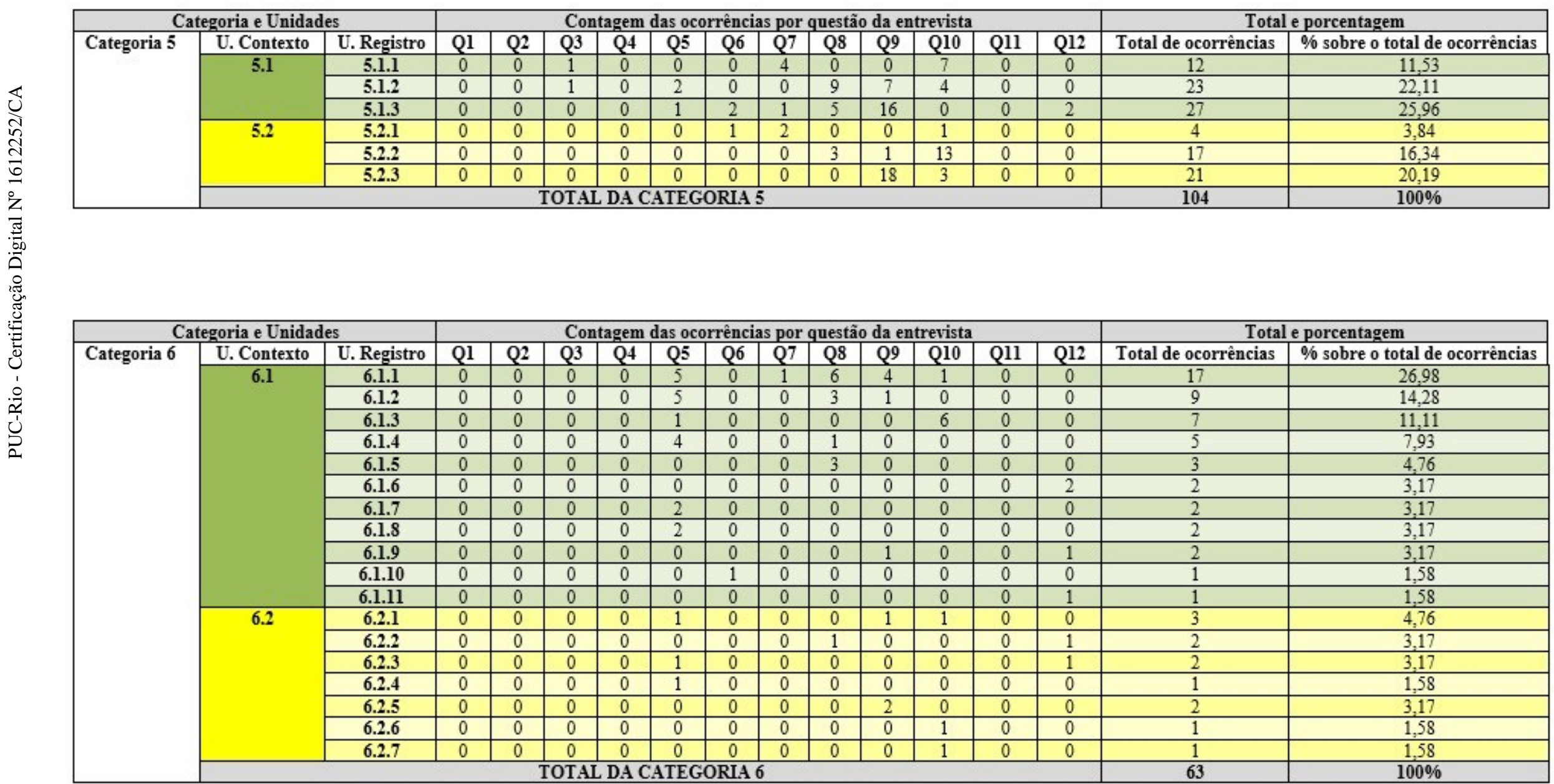




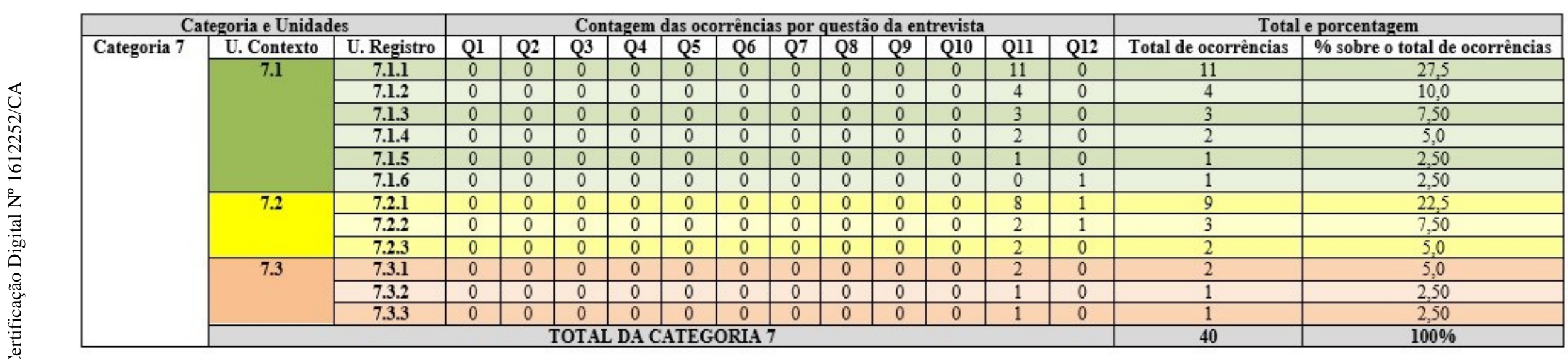




\section{Apêndice III - Texto de introdução do questionário online}

Olá. Meu nome é Cid Boechat e estou fazendo Mestrado em Design na PUC-Rio. Minha pesquisa é sobre o uso do Design e da Ergonomia como ferramentas organizacionais de equipes multidisciplinares de EAD. Minha pesquisa de campo está sendo feita no nosso setor de Material Didático do Cecierj.

Após entrevistar alguns colegas do setor, a pesquisa fez um levantamento sobre o cotidiano de trabalho da equipe e chegou a várias sugestões de melhoria, observações e questões que gostaria de validar com vocês. O Objetivo é descobrir se é possível construir, colaborativamente, um relatório com sugestões de mudanças e melhorias para um setor multidisciplinar de produção de EAD.

São questões rápidas, a serem respondidas com um click, e que levam, no total, de 5 a 7 minutos. As questões tratam de assuntos do setor, como processos de trabalho, cronogramas, andamento das aulas, entre outros.

Importante:

ESTA É UMA PESQUISA ACADÊMICA, SEM LIGAÇÃO OFICIAL COM A FUNDAÇÃO CECIERJ;

VOCÊ NÃO SERÁ IDENTIFICADO EM SUAS RESPOSTAS.

MUITO obrigado pela sua participação, ela é fundamental!
Esta pesquisa está de acordo com os parâmetros éticos brasileiros para pesquisas científicas. Para ver detalhes, acesse: https://goo.gl//kjXB3 (arquivo .pdf)

Se quiser saber mais sobre minha pesquisa de mestrado, acesse um resumo em: https://goo.gl/gptX3d (arquivo.pdf) 


\section{Apêndice IV - Pauta do questionário online}

O setor de Material Didático do Cecierj é formado por nove equipes: Diagramação, Produção gráfica, Design Instrucional, Revisão, Animação, Ilustração, Webdesign, Suporte e Vídeo. Desde 2015, esse setor trabalha reunido e num novo modelo integrado de produção das disciplinas. Nesse modelo, as equipes se juntam aos conteudistas e participam, desde o início, do planejamento dos materiais.

Neste questionário, trazemos algumas considerações coletadas nas entrevistas e pedimos para você marcar seu grau de concordância com elas. Além disso, gostaríamos da sua opinião sobre sugestões de mudanças e melhorias para o setor e o Cecierj. Vamos lá? :)

1- Em 2015, os antigos setores (DI, Impressos e Mídias Digitais) foram reunidos no mesmo espaço físico. Qual sua opinião sobre essa mudança?

( ) Era melhor antes, com salas separadas

( ) É melhor agora, com todos juntos

( ) É indiferente

Se quiser deixar um comentário sobre o assunto (opcional)

2 - "As equipes do Material Didático sabem muito pouco da rotina umas das outras. Não sabem quem faz o quê, como faz, quanto tempo leva." Sobre essa afirmação, você:
( ) Discorda totalmente
( ) Discorda parcialmente
( ) Não concorda, nem discorda
( ) Concorda parcialmente
( ) Concorda totalmente

Se quiser deixar um comentário sobre o assunto (opcional):
3 - "A falta de comunicação e de integração entre as equipes no setor de Material Didático dificultam o nosso trabalho." Você:

( ) Concorda totalmente

( ) Concorda parcialmente

( ) Não concorda, nem discorda

( ) Discorda parcialmente

( ) Discorda totalmente

Se quiser deixar um comentário sobre o assunto (opcional):

4 - "Com a fusão dos setores de DI, de Impressos e de Mídias Digitais, ficou muita coisa para dois diretores gerirem sozinhos". Você:

( ) Discorda totalmente

( ) Discorda parcialmente

( ) Não concorda, nem discorda

( ) Concorda parcialmente

( ) Concorda totalmente

Se quiser deixar um comentário sobre o assunto (opcional):

5 - "O Material Didático poderia ter sub coordenações de DI, de Impressos e de Mídias Digitais. Assim, as demandas ficariam menos centralizadas nos diretores". Pra você, essa é uma boa proposta?
( ) $\mathrm{Sim}$
( ) Não
( ) Acho indiferente

Se quiser deixar um comentário sobre o assunto (opcional): 
6 - Com base nas entrevistas, a pesquisa propõe um novo organograma para o setor de Material Didático (ver figura abaixo). Você acha que esta proposta melhoraria o fluxo de trabalho no setor?

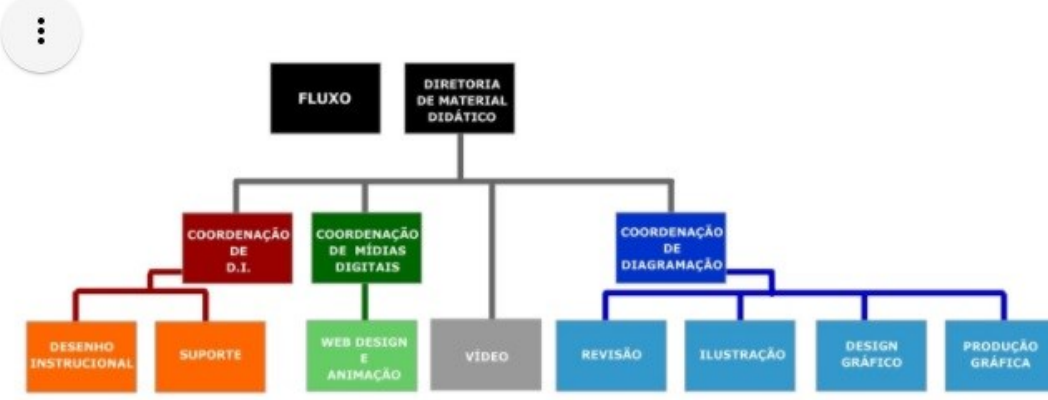

Para ver a imagem ampliada: https://goo.gl/GvZJzH
( ) $\operatorname{Sim}$
( ) Não
( ) Acho indiferente

Por favor, justifique sua resposta:

7 - "O Material Didático precisa de um processo de trabalho definido: quando começa a produção, quando deve terminar, quem participa de qual etapa. E com cronogramas que sejam respeitados." Você:

( ) Discorda totalmente

( ) Discorda parcialmente

( ) Não concorda, nem discorda

( ) Concorda parcialmente

( ) Concorda totalmente

Se quiser deixar um comentário sobre o assunto (opcional):
8 - "Uma ferramenta interna de acompanhamento da produção - onde se possa ver e atualizar o andamento do material - traria um fluxo de trabalho mais organizado e preciso". Você:

( ) Concorda totalmente

( ) Concorda parcialmente

( ) Não concorda, nem discorda

( ) Discorda parcialmente

( ) Discorda totalmente

Se quiser deixar um comentário sobre o assunto (opcional)

9 - "Deveríamos ter acesso claro e fácil ao perfil dos alunos e à avaliação institucional do Cecierj. Ajudaria a pensar melhor nosso trabalho." Você:

( ) Discorda totalmente

( ) Discorda parcialmente

( ) Não concorda, nem discorda

( ) Concorda parcialmente

( ) Concorda totalmente

Se quiser deixar um comentário sobre o assunto (opcional):

10 - "Tudo que o setor de Material Didático produz (ilustrações, animações, mudanças no Moodle, etc.) deveria ser validado com os alunos antes de ir para a web e para os livros". Você:

( ) Concorda totalmente

( ) Concorda parcialmente

( ) Não concorda, nem discorda

( ) Discorda parcialmente

( ) Discorda totalmente 
Se quiser deixar um comentário sobre o assunto (opcional):

11 - "Animadores, designers e ilustradores poderiam participar da capacitação dos conteudistas, para mostrar os recursos que o Material Didático produz." Você:

( ) Discorda totalmente

( ) Discorda parcialmente

( ) Não concorda, nem discorda

( ) Concorda parcialmente

( ) Concorda totalmente

Se quiser deixar um comentário sobre o assunto (opcional):

12 - "Os conteudistas das aulas em produção deveriam comparecer periodicamente ao setor (a cada 30 dias, por exemplo) para validar o material e tirar dúvidas". Você:

( ) Concorda totalmente

( ) Concorda parcialmente

( ) Não concorda, nem discorda

( ) Discorda parcialmente

( ) Discorda totalmente

Se quiser deixar um comentário sobre o assunto (opcional):

13 - "Às vezes, o conteúdo das aulas chega para o setor muito perto do início da disciplina. Não dá tempo de preparar o material didático adequadamente." Você:

( ) Discorda totalmente

( ) Discorda parcialmente

( ) Não concorda, nem discorda
( ) Concorda parcialmente
( ) Concorda totalmente

Se quiser deixar um comentário sobre o assunto (opcional):

14 - Em 2015, o Cecierj adotou um novo modelo integrado de produção do material didático. Considerando aspectos como fluxo de trabalho, resultados obtidos e qualidade do material, qual dos modelos você diria que funciona melhor?
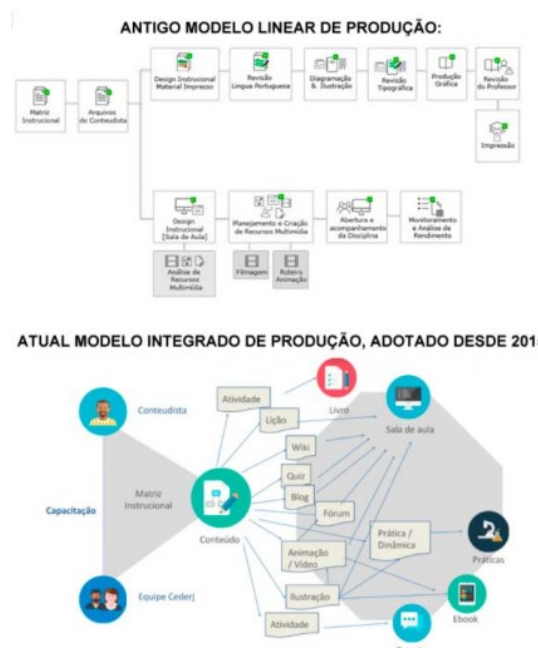

Para ver os modelos ampliados: https://goo.gl/bVzwzX

( ) O novo modelo funciona melhor

( ) O modelo antigo funciona melhor

( ) Não participei ainda de nenhuma disciplina no novo modelo 
Por favor, justifique sua resposta:

15 - Tendo participado de alguma disciplina "integrada", você diria que o novo modelo já está funcional? As equipes conseguem trabalhar bem nesse formato?

( ) Não, ainda não funciona bem.

( ) Sim, já funciona bem.

( ) Não participei ainda de nenhuma disciplina no novo modelo

Se você já participou de alguma disciplina no novo modelo integrado, que nota daria para o processo, de 1 (péssimo) a 5 (ótimo)?

$$
\text { ( )1 ( ) } 2 \quad \text { ( )3 ( )4 ( )5 }
$$

Se quiser deixar um comentário sobre o assunto (opcional):

16 - A primeira reunião com o conteudista da disciplina deveria ser com todas as equipes do setor ou só com os DIs?

( ) Como o início é muito embrionário, só com os DIs. Eles depois passariam a proposta da disciplina para os outros

( ) Com todas as equipes do Material Didático, para agilizar a produção e evitar retrabalho

( ) Acho indiferente

Se quiser deixar um comentário sobre o assunto (opcional):

17 - Das opções abaixo, qual você diria que é a melhor forma das equipes trabalharem juntas nas disciplinas?
( ) Trabalho em núcleos fixos: um DI sempre atuaria com o mesmo ilustrador, os mesmos designers, o mesmo animador, etc. - Isso traria entrosamento e, como resultado, um produto mais "coeso"

( ) Rodízio de profissionais: diferentes DIs trabalhando com diferentes designers, ilustradores, animadores, etc. - Permite maior integração entre as equipes do setor e maior troca de experiências, o que enriquece o processo

$$
\text { ( ) Acha indiferente }
$$

Se quiser deixar um comentário sobre o assunto (opcional):

18 - Abaixo, propõe-se uma revisão do modelo integrado de produção do material. Ela inclui maior participação dos alunos e dos conteudistas. Comparado com o modelo atual, que nota você daria para esta proposta, de 1 (péssima) a 5 (ótima)?
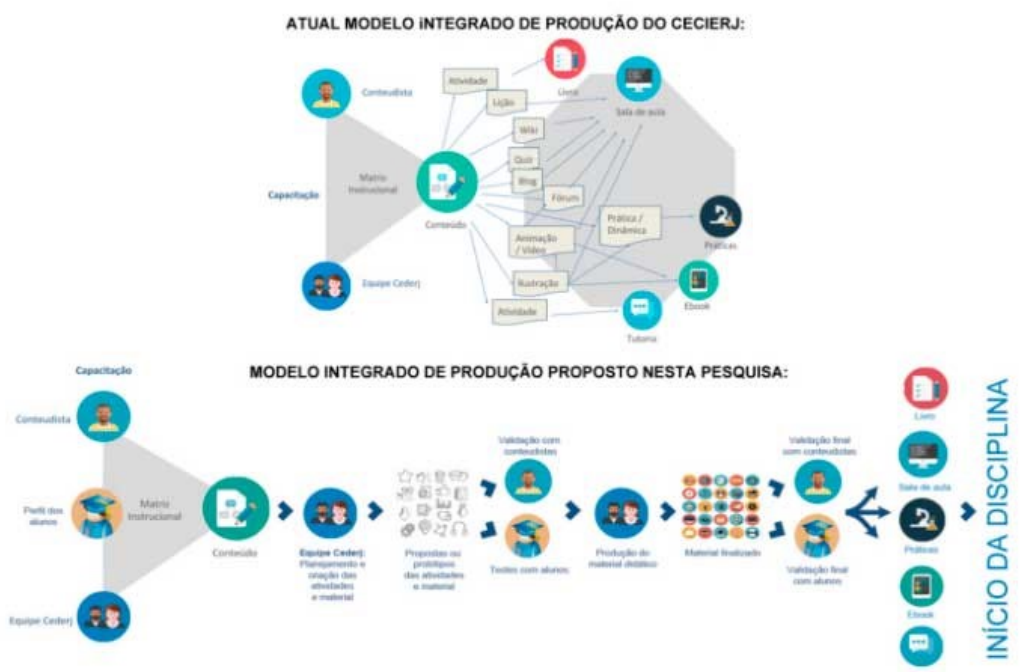

Para ver os modelos ampliados: https://goo.gl/hGDXnx 
( )1 ( )2 ( )3 ( )4 ( )5

Por favor, justifique a nota atribuída:

19 - "A falta de planejamento do Cecierj desmotiva e subutiliza o potencial dos funcionários". Sobre essa frase, você:

( ) Discorda totalmente

( ) Discorda parcialmente

( ) Não concorda, nem discorda

( ) Concorda parcialmente

( ) Concorda totalmente

Se quiser deixar um comentário sobre o assunto (opcional):

20 - "Assim como avaliam os cursos e os polos, poderiam nos chamar para avaliar o setor em que trabalhamos, as aulas e o Cecierj. Dar nossa opinião sobre o que pode ser melhorado." Você:
( ) Concorda totalmente
( ) Concorda parcialmente
( ) Não concorda, nem discorda
( ) Discorda parcialmente
( ) Discorda totalmente

Se quiser deixar um comentário sobre o assunto (opcional):

21 - "Eu já tive ideias, sugestões de implementação, mas foram 'barradas'. A gente não tem espaço para inovar." Você:

( ) Discorda totalmente
( ) Discorda parcialmente

( ) Não concorda, nem discorda

( ) Concorda parcialmente

( ) Concorda totalmente

Se quiser deixar um comentário sobre o assunto (opcional):

22 - "A Fundação tem muita burocracia e centralização. Toda pequena coisa tem que ser levada para um diretor, para o presidente. Isso deixa os processos muito longos." Você:
( ) Concorda totalmente
( ) Concorda parcialmente
( ) Não concorda, nem discorda
( ) Discorda parcialmente
( ) Discorda totalmente

Se quiser deixar um comentário sobre o assunto (opcional):

23 - "Poderíamos ser consultados periodicamente sobre a necessidade de compra ou de atualização dos softwares e dos computadores." Você:
( ) Discorda totalmente
( ) Discorda parcialmente
( ) Não concorda, nem discorda
( ) Concorda parcialmente
( ) Concorda totalmente

Se quiser deixar um comentário sobre o assunto (opcional):

\section{4 - Qual sua equipe no setor de Material Didático?}

( ) Animação 


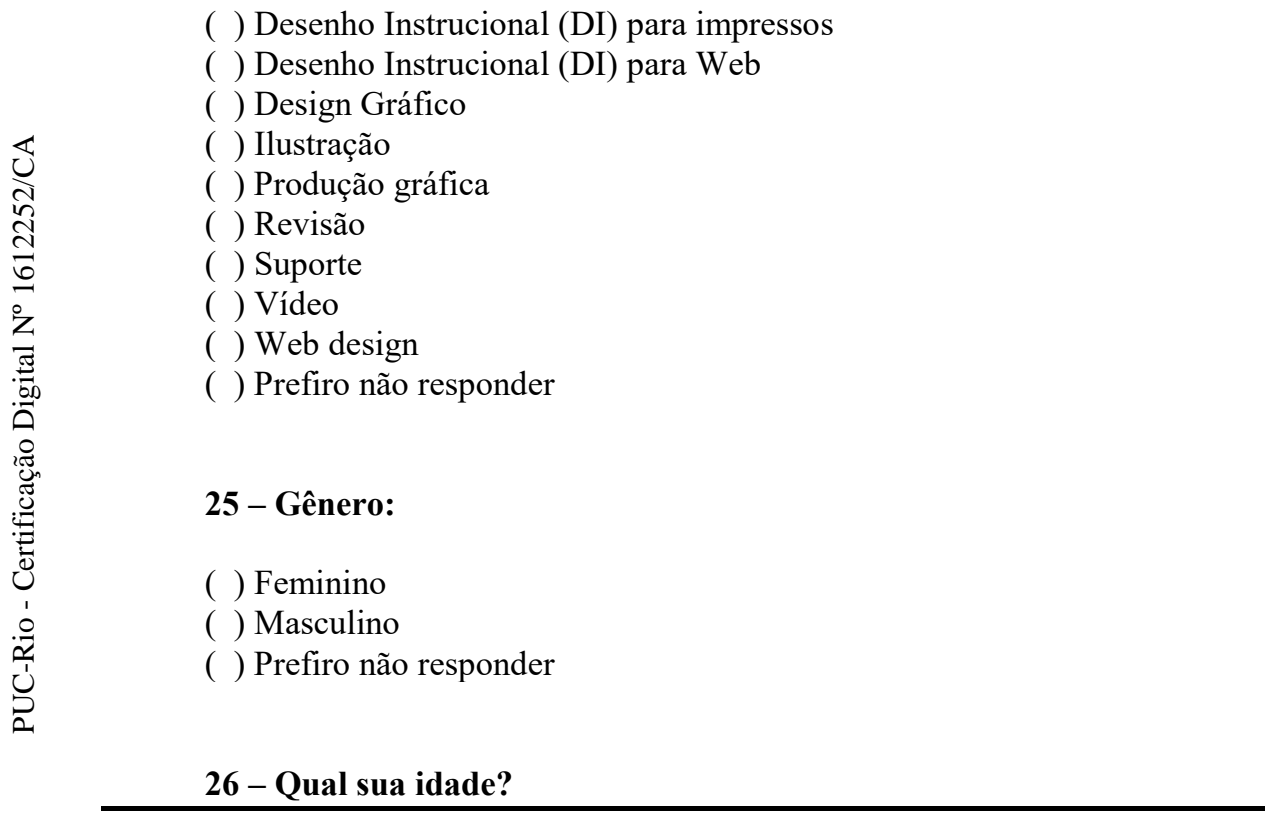




\section{Apêndice V - Comentários abertos dos respondentes do questionário online}

\section{1- Em 2015, os antigos setores (DI, Impressos e Mídias Digitais) foram} reunidos no mesmo espaço físico. Qual sua opinião sobre essa mudança?

- A união física dos ambientes não implica em união dos processos.

- Na minha opinião o espaço físico não influenciou.

- Acho que a ideia foi interessante, mas a mudança não refletiu em maior integração dos setores.

- O conceito de integração é interessante (e desejável), mas ele prescinde de que ocupemos uma mesma sala.

- Na prática não fez tanta diferença para o trabalho final, mas acho muito válida a possibilidade de mais interação e dos colegas se verem, e estarmos num mesmo espaço facilita isso.

- É bom frisar, que mesmo todos juntos, os DI ficam em um grupo, os WD, em outro, os DG em outro e assim por diante. As antigas baias, operaram uma divisão interessante no "todos juntos".

- Os setores possuem dinâmicas de trabalho diferentes. Por exemplo, alguns setores precisam de silêncio e concentração para fazerem revisões em textos ou produzirem conteúdos. Outros setores precisam de muito diálogo e troca de ideias durante os processos criativos. Neste exemplo, um setor atrapalharia o outro estando na mesma sala. O ideal seria que os setores ficassem cada um em sua sala e, no caso de haver uma necessidade de interação entre setores, faria-se um encontro em uma sala de reunião.

- A proximidade física ao meu ver não influenciou nos processo de trabalho

- Reunir todos em um espaço físico e não integrar, de fato, a produção e o pensar do material didático, seja impresso ou virtual, é irrelevante. O processo não foi repensado a fim de se estabelecer novas diretrizes de trabalho pra os integrantes das equipes.

- Não acredito que os problemas de funcionamento sejam decorrentes da união ou não dos setores.

\section{2 - "As equipes do Material Didático sabem muito pouco da rotina umas das} outras. Não sabem quem faz o quê, como faz, quanto tempo leva." Sobre essa afirmação, você:

- As equipes de material didático possuem planilhas de controle de produção que explicitam todas as tarefas e durações. Estes documentos são públicos. Além disso, no setor do DI há documentação para o fluxo de trabalho, também de acesso público.

- Acho que ainda não se conseguiu resolver essa falta de integração, talvez tenha sido um dos fatores que fez com que a mudança do espaço físico não tenha, na minha opinião, sido produtiva.

- Acho que, com esta tentativa de integração, já avançamos um pouco neste aspecto. Já aprendemos um pouco das rotinas de nossos colegas. No que tange ao Material Impresso, eu diria que este problema já não existe.

- Agora, após algum tempo trabalhando juntos, conhecemos um pouco mais dos procedimentos efetuados pelas outras equipes. Também foi 
elaborado um manual com todos os procedimentos para se operar um design integrado, unindo o impresso e o digital.

- Apesar de não gostar tanto da reunião dos setores, tenho que concordar que essa dinâmica conjunta me fez ter uma visão mais ampla do processo de trabalho das equipes.

- Muitas vezes ficavam lacunas em relação ao que cada parte da equipe fazia. Acredito que seja uma falha de gestão.

\section{3 - "A falta de comunicação e de integração entre as equipes no setor de}

\section{Material Didático dificultam o nosso trabalho." Você:}

- Tinha costume de trabalhar em equipes médias com uma chefia que supria as informações, passava as demandas e negociava prazos. Sempre gostei desse método. No estado não funciona assim

- Falta de comunicação em disciplinas de design integrado prejudica pois algumas pessoas acabam sendo excluidas do processo

- À medida que fomos conhecendo os novos colegas, ficou a cargo de cada um buscar compreender como cada colega trabalha, mas não por uma demanda específica das chefia, e sim, por curiosidade ou necessidade.

- Comunicação é a palavra chave, era deficiente antes, continua deficiente agora.

\section{4 - "Com a fusão dos setores de DI, de Impressos e de Mídias Digitais, ficou} muita coisa para dois diretores gerirem sozinhos". Você:

- $\quad$ Fica, eles são conta, mas ficam muito sobrecarregados
- Apesar da possível sobrecarga (é mais uma percepção, pois não tenho informações suficientes para avaliar) acho que facilita a integração no trabalho.

- A gestão, ficou um pouco maior. Mas na verdade, diminuiria muito se houve uma melhor organizado de como são feitas as coisas. Cria-se muitas planilha d complexas de serem preenchidas, que levam muito tempo e não controlam nada.

- O processo de como fazer as coisas muda o tempo todo, deixando os Di's confusos e dando mais trabalho aos diretores

- Não são tantas pessoas para gerir, desde que houvesse um plano de gestão claro, onde todos fossem cientes do mesmo é soubessem seu papel.

\section{5 - "O Material Didático poderia ter sub coordenações de DI, de Impressos e} de Mídias Digitais. Assim, as demandas ficariam menos centralizadas nos diretores". Pra você, essa é uma boa proposta?

- Não sei se a sub-coordenação citada é diferente das coordenações já existentes nesses setores.

- Já existem coordenações

- Os diretores precisam de tempo para as decisões macro, o trabalho cotidiano fluiria melhor com sub-coordenações, que poderiam acompanhar de modo mais detalhado/ próximo as pequenas questões cotidianas.

- Acredito que os setores possam se autogerir. Na Revisão, por exemplo, optamos por não centralizar o poder na mão de uma só. Todas temos voz, todas nos sentimos parte, todas somos uma coisa só. Quando necessário, 
elegemos alguma representante que leve para fora as questões debatidas em grupo.

- Já existem coordenadores dentro dos setores de DI e MDI (de mídias digitais não sei), que acredito que dão conta do trabalho das equipes menores (diagramação, revisão, ilustração etc.). Sou contra haver lideranças nessas equipes e a favor de que elas tenham autonomia e iniciativa para estabelecer entre si a divisão das tarefas por disciplinas, cursos ou outro critério, para que possam melhorar os processos.

- Seria o famoso 'muito cacique para pouco índio'

- A integração foi feita justamente para não ter mais di impresso e digital. É para ter uma interseção dos dois. Um complementar o outro. Não é necessário ter um livro específico em certos momentos, apenas um vídeo, uma atividade ou um texto complementar q o professor possa achar interessante.

- Desde que esses coordenadores trabalhassem em parceria com as equipes em vez de focarem exclusivamente em trabalhos burocráticos que têm outras finalidades além da gestão do seus respectivos setores

- Como disse anteriormente, acredito que um plano de gestão eficaz, montado após a consulta aos funcionários seria mais eficaz.

\section{6 - Com base nas entrevistas, a pesquisa propõe um novo organograma para o setor de Material Didático (ver figura abaixo). Você acha que esta proposta} melhoraria o fluxo de trabalho no setor?

- Alguém coordenando é a melhor forma de distribuir de forma justa o trabalho
- O organograma parece lógico, mas não tenho segurança para afirmar que o fluxo de trabalho melhoraria, pois enfrentamos outros problemas muito sérios inclusive em estágios hierárquicos superiores ao representado.

- No meu entender, estás funções de coordenação já são exercidas, ainda que os servidores nelas alocados não possua cargos oficiais.

- $\quad$ Fica mais organizado.

- Sim, porque teríamos um controle melhor da distribuição das tarefas, prazos etc.

- O problema não é gestão de processos, mas de pessoas. Não acredito que hierarquias resolvam a questão.

- $\quad$ Ajudaria, mas penso que o problema maior é de gestão de pessoas e não de organograma.

- Creio que a gestão compartilhada funciona de forma mais eficaz.

- "Diretoria" e "Coordenação" se confundem. É preciso aglutinar os que "geram" o conteúdo e também os que "desenvolvem" o conteúdos nas diferentes mídias. Vídeo não pode ficar isolado. E Digital tem que estar perto de impresso (que vai se tornar impresso-ebook)

- Me parece uma estrutura bem coerente. Mas não entendo porque o vídeo não está subordinado a coord de midias digitais. Acho que isto cria uma falha na integração, já que fica diretamente ligado à diretoria.

- Acho que esta proposta (e qualquer outra) só pode funcionar se cada cabeça tiver direito a voz e voto. Não acredito em que representantes que falem pela maioria sem consultá-la previamente. 
- É como ja funcionava. Talvez desmembrar mais a coord de diagramação e a prod. Grafica ser independente.

- Acho que melhora, mas já não é assim que fazemos?

- Coodenações específicas com pessoas que tenham noção das funções específicas ajudam no gerenciamento.

- Uma observação. A animação deveria estar mais integrada ao vídeo do que a webdesign

- O Setor de Vídeo poderia estar ligado diretamente ao retângulo das Mídias Digitais

- O Setor de Fluxo parece estra mais ligado às Coordenações de DI e de Diagramação

- A grande questão para melhorar o Fluxo, não está representada no Organograma. É o tempo que os professores conteudistas possuem para construírem os ambientes virtuais e os materiais impressos para os alunos. Frequentemente, este prazo de elaboração é descumprido por diversos fatores, o que gera inúmeros problemas tanto para as equipes responsáveis pelas disciplinas como para os alunos.

- Me parece um fluxograma bastante semelhante ao que temos atualmente.

- Como dito anteriormente, há muitas funções para que apenas dois diretores deem conta.

- Creio que possa ser um teste a ser feito

- Com este organograma apresentado, os setores possuem coordenadores mais especializados em cada área de atuação, o que melhora o direcionamento das equipes, descentraliza e qualifica as tomadas de decisão.
- Acho que a coordenação de DI deveria ser a mesma de mídias digitais, pois os DIs devem ter contato direto com a equipe de mídias, por isso não se justifica separar os dois. As propostas de aprendizagem devem ser discutidas entre as duas equipes, que devem possuir a mesma coordenação.

- Incompetente a responder

- Acho que o antigo Setor de Mídias Digitais funciona melhor com uma chefia específica.

- Coordenações descentralizadas otimizam o processo.

- Acho importante e mais eficiente existirem coordenações de cada setor.

- Não prática é isso que já acontece. Temos coordenadores de DI, coordenador de Mídias digitais e coordenação de Material impresso.

- No material impresso já funciona bem parecido.

- Eu agruparia as equipes de forma diferente: DI+Revisão; Ilustração+animação+video; Web+Suporte; Design Gráfico+Produção Gráfica.

- Honestamente, não entendo como esse organograma funcionaria... Devese entender que o designer instrucional deveria funcionar como um gerente de projeto, trabalhando em conjunto com os ilustradores, professores, animadores, etc.

- Para eu dar uma opinião sobre este organograma, devo ver como vc está pensando na dinamica que ocorrerá. 
- Somente, ter atenção ao nome do setor de diagramação, pois este realiza outras funções, como revisão de LP, ilustração. Algo como produção editorial, seria algo a se pensar. Outra questão é o papel do fluxo, poderia ser usado um sistema de gerenciamento, os DIs serem responsáveis pelos projetos, prazos e contatos com os professores, como funciona em outras grandes empresas. Assim, não haveria necessidade de um fluxo entre os setores, uma vez que estes são integrados atualmente, e os DIs podem gerienciar todo processo inicial de confecção das aulas junto ao conteudista.

- Modificações no organograma só funcionariam se gestores fossem menos centralizadores.

- É basicamente a estrutura anterior, que possuía diversas falhas.

- Essa opção não contempla a real função de um DI

- Falta separar Di web de impresso. Há pessoas com competências, experiências e rendimento melhor específicos em cada área e cada área tem suas particularidades para serem definidas como um único bloco.

\section{7 - "O Material Didático precisa de um processo de trabalho definido:} quando começa a produção, quando deve terminar, quem participa de qual etapa. E com cronogramas que sejam respeitados." Você:

- Tudo funciona melhor com cronograma, mas na prática tem que ser negociado, existem muitas variáveis fora do nosso controle.

- A diferença de velocidade de produção entre as tarefas de criação (ilustradores, DIs, etc) traz extrema complicação ao fluxo de produção. Em especial por não haver aferição da qualidade do produto final frente ao tempo investido em sua produção.
- Tem q envolver conteudistas e demais atores q participam indiretamente do processo.

- É importante que o estabelecimento de prazos não prejudique a qualidade do trabalho. Além disso, a celeridade não depende só dos servidores da

Cecierj, estamos muito pendurados também nos professores conteudistas.

- O processo de trabalho de todas as equipes estão sempre submetidas a um fator externo que é o professor que se encontra fora do processo interno de produção das equipes e seu comprometimento com a produção material é subjetiva e de difícil controle. Assim sendo, acho difícil aplicar conograma nesse processo

- Destaco que pe importante considerar as diferentes formas de trabalhar dos setores. Por exemplo em uma planilha o cronograma deve ser pensado de de forma a atander as diferentes demandas de cada trabalho.

- Mas o cronograma não funcionaria pq um dos grandes problemas é o relacionamento com os conteudistas.

- O material didático não é uma coisa estática que funcionará para sempre. Muitos dos cursos tem conteúdos de vida útil extremamente curta. Devese sempre renovar as produções. Essa é a função do designer instrucional, trabalhar junto com o professor o conteúdo. Porém concordo q deva haver um cronograma, com prazo para os pequenos projetos dentro da disciplina ou curso.

- Se não tiver flexibilidade, a qualidade pode cair. Há variáveis de recursos humanos, política e burocracia a serem consideradas.

8 - "Uma ferramenta interna de acompanhamento da produção - onde se possa ver e atualizar o andamento do material - traria um fluxo de trabalho mais organizado e preciso". Você: 
- Temos ferramentas de controle, mas deveria ser algo fácil simples e unica

- Uma ferramenta de mercado, profissional, sem ser quebra-galho, seria essencial.

- Um sistema mto complexo. Deve-se contratar empresa especializada para produzir algo personalizado.

- No MDI já fazemos isso.

- Concordo se o professor estiver incluído nesse processo e seja cobrado pela produção em conjunto com a equipe.

- Depende da ferramenta... Algumas ferramentas só criam mais uma camada de trabalho e pouca transparência.

- Gostaria de saber que ferramenta vc pretende utilizar. Há que essas é uma das principais discussões que temos entre os di's

- Já tentaram usar uma ferramenta similar e não deu certo. Antes de utilizar uma ferramenta para acompanhar é necessário planejar um fluxo mais eficaz, simples de entender, enxuto e sem grandes extravagâncias para colocar em prática.

- Se forem planilhas complexas que meia dúzia de pessoas entendem, não adianta de nada.

9 - "Deveríamos ter acesso claro e fácil ao perfil dos alunos e à avaliação institucional do Cecierj. Ajudaria a pensar melhor nosso trabalho." Você:

- Parte destes dados é pública, mas acessá-los é um suplício.
- Seria interessante, desde que associado com alguma ação ou planejamento.

10 - "Tudo que o setor de Material Didático produz (ilustrações, animações, mudanças no Moodle, etc.) deveria ser validado com os alunos antes de ir para a web e para os livros". Você:

- Somos profissionais capacitados para isso

- Conforme está, o tempo de produção já é extremamente dilatado. Mais um ator neste processo implica em maior tempo de produção. Além disso, no mundo todo os cursos são avaliados pelos estudantes em seu decorrer e término. Apenas na Fundação Cecierj isso não ocorre. Bastaria implementar.

- Acho que criaria um processo interminável devido ao volume de trabalho, à quantidade de alunos e à subjetividade da questão. Acho que seria mais produtivo uma pesquisa com periodicidade regular (anual, semestral, não sei), ou um canal de interação direto (não sei qual seria o melhor: talvez um link na plataforma: "qual sua opinião sobre os materiais didáticos? seguida de itens para o aluno opinar"), em que os alunos pudessem enviar suas opiniões, críticas e sugestões.

- A princípio discordo totalmente, mas se alguém apresentar argumentos, posso mudar de ideia.

- As decisões de cunho politico interferem diretamente no perfil criativo da equipe, limitando a criatividade e produção da equipe para fins nada pedagógicos.

- $\quad$ Sim e não. Sim, porque acho que antes de se montar uma disciplina, é necessário fazer uma pesquisa sobre o que o aluno gostaria de ver, ter, e interagir dentro da plataforma. Que tipo de tecnologia e conteúdo ele acha que seriam interessantes. $\mathrm{O}$ que ele gostou e o que não gostou nas 
disciplinas já cursadas, etc. Ou seja, o ideal seria fazer uma pesquisa sobre o perfil do aluno e o que ele está achando dos cursos. Digo também "Não" porque nem "tudo que o setor de Material Didático produz" deve ser valiado pelo aluno. Há materiais que podem ser produzidos com base na pesquisa supracitada, o que daria agilidade na montagem das disciplinas.

- Isso seria bom, mas poderia atrasar o cronograma de produção. Sugiro fazer por amostragem e não todos os recursos produzidos passarem por essa validação.

- Não sei se tudo. Não sei se seria possível. Mas coisas grandes como mudanças no Moodle, sem dúvida.

- $\quad$ Pode até ocorrer uma avaliação dos alunos antes, mas não acho muito necessária. Acho q seria interessante uma avaliação durante ou após o curso. Para que no próximo semestre ela possa ser melhorada

- Quando conseguirmos trabalhar com prazos menos apertados, sim

- A validação dos alunos deve ser da metodologia é não dos produtos finais.

- Acredito que deva se entrevistar alunos, entender seu perfil, sugerir propostas de mudança e observar grau de satisfação e eficiência dessas mudanças e mudá-las se tiver repercussão negativa. O que funciona pra um perfil de aluno pode não funcionar pra outro. No processo didático isso é muito orgânico e individual.

\section{1 - "Animadores, designers e ilustradores poderiam participar da} capacitação dos conteudistas, para mostrar os recursos que o Material Didático produz." Você:
- Para além de mostrar, seria necessário capacitar os professores do adequado uso de cada uma desses recursos. Isso demandaria um curso em separado, é totalmente inviável no tempo de capacitação que dispomos.

- Talvez um momento "workshop" ou uma pequena palestra orientadora do que são estas funções e seus respectivos papéis no MD.

- O que falta é a capacitação ser obrigatória e efetiva

- Isso foi feito na união das equipes em palestras

- Acho importante que consigam comunicar aos professores a potência desses recursos e explicitar nossa expertise nisso. Isso poderia ser feito por um dos profissionais do campo ou pela própria coordenação/diretoria.

- Deveria haver uma pequena imersão, mostrar um portifolio do que é possível fazer tb seria algo bem legal

- Já existe uma sala de apresentação dos potenciais destas equipes e que é passado em treinamento. No mais, depende do perfil de conteudista para que isso seja feito. Nem todo conteudista é coordenador de disciplina.

\section{2 - "Os conteudistas das aulas em produção deveriam comparecer}

periodicamente ao setor (a cada 30 dias, por exemplo) para validar o material e tirar dúvidas". Você:

- Deve existir um canal de comunicação, mas que funcione de acordo com a necessidade. Se a dúvida é agora, não adianta sanar em 30 dias qdo o material já estiver terminado

- As agendas dos conteudistas é sempre cheia, e eles encaram este trabalho como um freela. Esta sugestão é totalmente inviável. 
- Não sei opinar.

- Nem sei se é necessária a presença física, mas que os conteudistas precisam ser mais "reais", ah, isso precisam. A pessoa que assume a tarefa de gera conteúdo para as aulas precisa ser acessível.

- Caso o material esteja em dia e nao atrasado, senao esse periodo deve ser revisto.

- Não necessariamente o comparecimento físico do professor, mas que houvesse uma comunicação eficaz entre este e a equipe que o auxilia. Isto já resolveria a questão. Atualmente, por vezes, a equipe faz contato com o professor, via e-mail e fica muito tempo sem resposta.

- Concordo que exista um documento assinado pelos professores com suas obrigações na produção do material para que tal comprometimento seja oficial e não de boca a boca

- Acho importante estes encontros mensais, mas, além destes encontros, deveria haver um acompanhamento diário, ou seja, o conteudista deveria poder ver online o material sendo produzido quase que "on time". Isso seria possível usando-se ferramentas como o Google drive. Ao final de cada dia, o setor poderia publicar o material já montado para que o conteudista possa avaliar e fazer os comentários diariamente.

- Não é necessário se o contato por email com o DI for constante.

- Há dificuldades nesse processo, já que há locais distantes, fora da cidade. Mas concordo que deveriam ocorrer reuniões periódicas, sendo a equipe indo aos professores mais distantes, seja os professores indo até a equipe. Logo que entramos isso acontecia com os professores novos.
- Acho importante o acompanhamento, mas se não conseguimos fazer isso com ferramentas à distância (Skype por exemplo), como nos intitulamos uma instituição que trabalha com EaD

- Em se tratando de EAD, acredito que a melhor forma de se fazer isso é na própria plataforma, ou pela via web sem necessidade de presença, mas deveria haver um controle para evitar dispersão e demora nessas validações. No caso de material impresso, acho que depende de outros fatores e características específicas do setor de impressos que podem dizer melhor se a periodicidade de 30 dias é uma possível realidade ou não.

\section{3 - "Às vezes, o conteúdo das aulas chega para o setor muito perto do início} da disciplina. Não dá tempo de preparar o material didático adequadamente." Você:

- Sou revisora e meu trabalho ou é rápido ou é bom. As duas coisas não dá. E eu prefiro que seja bom.

- Tal situação acontece por causa do cunho politico das decisões tomadas pelos gestores da fundação para aumentar a visibilidade da instituição e não prezando pela qualidade dos conteúdos e sim pela quantidade.

- Esse processo de construção das aulas deveria ocorrer pelo menos 1 ano antes.

- Qual setor?! Rs. Acho que há má distribuição do tempo do projeto e do conteúdo nas diferentes etapas de construção da disciplina. É acho que há uma subvalorização - muito pelo desconhecimento da capacidade técnica e potencial criativo - de algumas áreas em detrimento de outras.

14 - Em 2015, o Cecierj adotou um novo modelo integrado de produção do material didático. Considerando aspectos como fluxo de trabalho, resultados 


\section{obtidos e qualidade do material, qual dos modelos você diria que funciona} melhor?

- Não percebi a mudança, acho tudo muito confuso

- Os sucessivos atropelos de greve, duas mudanças de prédio, atrasos salariais, demandas de trabalho de outros setores etc me impedem de comparar os dois modelos.

- O modelo integrado depende de muita estabilidade institucional para funcionar, e a Fundação Cecierj não dispõe disso. O modelo integrado é superior ao antigo, mas inviável para a instituição.

- Não é possível opinar ainda.

- O novo modelo ainda apresenta diversos problemas na prática, mas acredito que poderia funcionar melhor se fosse melhor planejado (e cumprido).

- Apesar dos pesares

- $\quad$ porque agrega mais valor e todos participam

- não participei

- A crise atrapalha nessa constatação

- Para a plataforma, me parece mais funcional. Para o material impresso (ou e-book), acho que o processo ainda continua como antes, a diferença fica apenas na construção da matriz instrucional. Diferença positiva para a construção da disciplina como um todo.
- Infelizmente, com a crise, as disciplinas novas em cujas equipes fui inserida ainda não saíram do papel. Aguardo ansiosa pela volta à normalidade, pois tenho a certeza de que o novo modelo é melhor.

- Me parece q o segundo funciona melhor, ate pelo q ouço falar. Mas nao participei na pratica da construção.

- O novo modelo é definitivamente melhor, mas impossível levá-lo à frete com essa crise e todas as interrupções no processo.

- Houve maior integração das equipes e participação dos responsaveis pelas diferentes ferramentas

- O novo modelo "funcionaria melhor", se os prazos dados aos professores conteudistas fossem cumpridos. 2- Com a equipe junta, pensando (DI, $\mathrm{WD}, \mathrm{DG}, \mathrm{R}, \mathrm{I}, \mathrm{V})$ e o professor conteudista detalhando os aspectos das aulas, fica muito mais rico o fazer sugestões para os conteúdos e para as atividades componentes do curso. 3- Os tipos de recursos empregados podem ser melhor trabalhados, pois o horizonte de análise é maior que antes: 3.1- Recursos específicos para o meio impresso 3.2- Recursos específicos para o meio digital 3.3-Recursos que podem ser desdobrados no digital a partir do impresso

- Porque há mais profissionais de ead envolvidos no início do processo. Facilita muito!

- Não participei ainda.

- Não creio que se possa criar opinião sobre qual modelo é melhor pois em 2 anos houveram fatores externos que influenciaram diretamente na produção do material como greves, paralisações, mudanças de sede e crises financeiras do estado. Assim sendo, creio que a comparação dos dois modelos é impossível no momento. Deveria ter a opção de não tenho 
como opinar sobre essa questão nesse item pois participo de novo modelo mas ainda não chegamos no final da produção para opinar.

- O novo modelo tem potencial para funcionar melhor que o antigo modelo, porém o novo modelo precisa de um alto grau de gerenciamento, pois são muitos cruzamentos entre setores e pessoas, o que pode deixar confuso e dificultoso o fluxo de trabalho. $\mathrm{O}$ modelo antigo é um mais "duro" e "amarrado", mas é mais fácil de se gerenciar, pois é mais cristalino e previsível.

- A proposta do modelo novo é melhor, entretanto não apresentou os resultados esperados, pois o processo é muito longo. Por isso foi proposto um terceiro modelo chamado de fluxo único, que tem como objetivo acelerar o processo de produção das disciplinas novas, das disciplinas em retrofit e das disciplinas em terminalidade.

- Incompetente a responder

- Acho que dependendo da disciplina, poderia ser escolhido o método mais adequado.

- $\quad$ Ainda não pude perceber a diferença

- Não tenho informações suficientes para opinar.

- Na teoria esse tipo de trabalho tem potencialidades para agilizar o processo e trazer mais organização ao estudante.

- Porém ainda precisa de ajustes.

- Não participei. Mas me agrada a ideia de todas as mídias serem pensadas em conjunto em vez de uma linha de produção como uma fábrica.
- Para ser sincera, deveria ter uma opção nenhum dos dois rsrs Por mais que não tenha participado deste novo modelo, vejo meus colegas trabalhando, e tem muita coisa que não funciona. Ainda é um modelo experimental, precisa muita coisa ser melhorada. Mas concordo que o modelo antigo não funciona.

- $\quad$ Não participei

- Não participei do processo integrado

- Deveria ter uma opção dizendo que nenhum dos modelos funciona. Olhando apenas no papel o novo modelo se encaixa mais nos padrões para onde a EaD está indo, mas sem o planejamento adequado funciona tão mal quanto o anterior.

- O modelo novo tem mais chances de produzir material com mais qualidade.

- O novo modelo "funciona" um pouco melhor por haver tentativas maiores de inclusão das diferentes áreas de produção do setor. Porém, ainda possui muitos vícios e travas do modelo antigo e muita ignorância sobre processos (ainda um ranço do modelo anterior).

15 - Tendo participado de alguma disciplina "integrada", você diria que o novo modelo já está funcional? As equipes conseguem trabalhar bem nesse formato? / Se você já participou de alguma disciplina no novo modelo integrado, que nota daria para o processo, de 1 (péssimo) a 5 (ótimo)?

- Caso a instituição oferecesse o necessário ao pleno funcionamento do modelo, a nota seria 4 .

- Não deveria ser avaliado e comparado ao modelo anterior já implementado como melhor ou pior porque o novo não foi 
completamente implementado e ainda está em fase de testes em apenas 1 disciplina. Não há tempo nem amostra suficiente para tal comparação.

- As disciplinas de que participei ainda não voltaram para mim, e faz cerca de 2 anos que me reuni com as equipes e o professor.

- Existe muita demanda e que deve ser montada pela equipe de forma rápida, porém voltamos ao problema do prazo dado aos professores conteudistas não ser cumprido.

- Apesar de achar o design integrado muito bom, não tivemos tempo de ver os resultados desse tipo de trabalho.

- Creio que não possa opinar pois ainda não temos dados para afirmar se funciona ou não

- O modelo até me parece bom, mas é difícil de se gerenciar.

- Acredito que o fluxo único vai apresentar melhores resultados.

- Participei de ambos os tipos: disciplina que foi bem e uma que não foi tão bem no início.

- Falta de comunicação e pulo de processos prejudicou a disciplina que participei

- São poucos os dis que participam de uma disciplina com projeto integrado. Mas ela ainda está em fase experimental.

- Não participei mas não consegui desmarcar a caixa

- Ainda sobrevive muitos vícios do processo anterior e o perfil pessoal e profissional dos integrantes na delegação dos mesmos para cada equipe ainda não é tão levado em consideração, bem como o processo como esta sendo prevê que todos tenham um mesmo perfil pessoal e o mesmo tipo de motivação e rendimento.

\section{6 - A primeira reunião com o conteudista da disciplina deveria ser com todas} as equipes do setor ou só com os DIs?

- Acho reuniões longas improdutivas, as coisas tem que ser mais objetivas, dinâmicas e produtivas

- Com todas as equipes. Mas a principal função não é agilizar o processo. E dar real dimensão ao conteudista do processo no qual ele está inserido, da quantidade de profissionais altamente qualificados que estarão analisando e melhorando seu material.

- Ainda que o início seja embrionário, acho importante o contato com o conteudista. Talvez não precise ser na primeira reunião, mas em algum momento do processo junto ao conteudista. Sempre será diferente de ouvir apenas através do "filtro" do DI. Um designer ilustrador ou diagramador, poderá trazer questões que não ocorreram aos DIs.

- Talvez todas as equipes não sejam necessárias em TODAS as primeiras reuniões, mas, com certeza, discordo que seja funcional jogar para os DIs a responsabilidade de passar a proposta para o "resto". Muitos problemas seriam evitados se, ao longo do processo, representantes das demais equipes puderem dialogar diretamente com o conteudista

- Reuniões com muita gente são pouco produtivas. Seria melhor que dois ou três DIs com uma visão global das atividades do setor participassem da reunião. Depois disso, eles traçariam as estratégias de trabalho com base na capacitação de cada área de atuação do setor. Numa segunda reunião, eles transmitiriam as as estratégias para os outros profissionais. Nesta reunião seriam acertados detalhes técnicos e prazos. 
- Novamente, acho q ter toda a equipe é importante. Mas lembrando que o designer instrucional deve ser o gerente de projeto da disciplina

- O momento embrionário é o mais sensível à propostas, principalmente de pessoas envolvidas com criação.

\section{7 - Das opções abaixo, qual você diria que é a melhor forma das equipes} trabalharem juntas nas disciplinas?

- O rodízio traz agilidade ao processo. Fechar equipes impede deslocar profissional momentaneamente ociosos para projetos novos.

- Na atual conjuntura, com o número de profissionais que temos, não considero sequer possível a primeira opção.

- Acho que a melhor forma de se trabalhar é dividir a equipe em "agências". "Agência" de DI, "agência" de webdesign e animação, "agência" de design gráfico e ilustração etc. Em cada "agência" haveria um coordenador que escolheria o profissional a trabalhar nesta ou naquela disciplina, de acordo com a dinâmica da "agência".

- A segunda é melhor, mas exige muita organização e ótimo planejamento. Poderia começar com a primeira e migrar aos poucos para a segunda.

18 - Abaixo, propõe-se uma revisão do modelo integrado de produção do material. Ela inclui maior participação dos alunos e dos conteudistas.

Comparado com o modelo atual, que nota você daria para esta proposta, de 1 (péssima) a 5 (ótima)?

- Ainda acho muitas etapas, tem que fazer um metodo, testar e implantar. E anualmente avaliar. Esse vai e vem de aprovação o tempo todo é improdutivo
- Me parece ideal, mas será que teremos disponibilidade de tempo e recursos pra implantar na prática?

- Conforme dito anteriormente, o impacto no prazo de produção da participação dos estudantes seria bastante prejudicial ao processo. Além disso, os estudantes podem exercer o mesmo papel durante e após o curso, como é praxe em outras instituições e como deveria ser na Fundação.

- $\quad$ Parece mais organizado.

- Acredito que a participação dos Alunos seja importante para um feedback

- A imagem do modelo integrado é a conceitual e antiga e não representa o fluxo de trabalho do modelo integrado, que se encontra num arquivo textual. O modelo proposto apresenta um fluxo de trabalho. Por isso acho difícil comparar um e outro.

- Pensando melhor após responder, entendi a proposta, por isso respond novamente. favor desconsiderar a primeira resposta ao questionário.

- otima proposta

- Não foi possível contemplar no momento

- Tenho dúvidas em relação à "validação do aluno", talvez em forma de testes. Tenho dúvidas se poderia tornar o processo muito longo. São dúvidas mesmo. Acho que envolve muita subjetividade. Acho muito importante definir o perfil e fazer os testes iniciais, a validação tenho dúvidas.

- Acho que o caminho é esse: é preciso haver mais troca. O modelo anterior é excessivamente engessado e leva ao alienamento das partes. 
- Acho mto valida a proposta, so tem q ser testada na pratica para ver se funciona e serem feitos ajustes no processo.

- Acho que introduzir os alunos pode dificultar muito o processo, mas posso mudar de ideia.

- Nota-se uma tentativa de estabelecer uma metodologia. O projeto assim fica menos na base da tentativa e erro e fica mais no projeto.

- Realmente é bem interessante a proposta nova. Eu nunca havia pensado nisto desta maneira. No entanto, não ficou claro para mim, quais seriam estes alunos. No meu entendimento, deveriam ser alunos, que já tivessem passado pela disciplina, pois poderiam avaliar melhor o que a equipe elaborou. Outrossim, poderíamos usar a avaliação dos tutores tanto os presenciais quanto os a distância, sobre como melhorar aquilo que foi feito, excluir elementos que não contribuíram para o aprendizado e operar inclusões de outros recursos, que na opinião deles, melhorariam a compreensão do eadista.

- Não sei avaliar. Não acho que tenha compreendido bem a participação dos alunos.

- Acho muito boa a inclusão de conteudistas e alunos no processo.

- Como o cliente final do processo é o aluno, este deveria estar presente no provesso criativo com testes de usabilidade .

- $\quad$ Acho que não deve haver "testes com alunos", pois sempre aparecerão necessidades de melhoria, o que deixaria esta fase de testes muito demorada. Acredito que apenas com a avaliação do perfil do aluno no início do modelo já seria possível montar um material bem de acordo com a expectativa do aluno. Ao final da disciplina, poderia haver um canal de "ouvidoria" para o aluno apontar possíveis melhorias para o semestre seguinte.

- Na verdade na proposta atual os conteudistas já atuam no processo, validando cada etapa. O que vi de diferente nesta proposta foi a inclusão dos alunos no processo de validação, que eu acho bom, mas sugiro ser por amostragem para não atrasar ainda mais o processo de produção.

- Incompetente a comentar

- Os testes com alunos são uma boa ideia! Afinal, eles são nosso "públicoalvo"! Os conteudistas, a meu ver, já têm suficiente acesso ao material durante sua elaboração. Acho a proposta válida!

- O testo com o aluno poderia ser pulado

- Não tenho certeza quanto a necessidade de validação final com os alunos.

- É preciso avaliar o qnt trazer os estudantes pode tornar o processo mais moroso do que já é.

- Somente a avaliação com os alunos, talvez devesse ocorrer no final da disciplina, como acontece em aulas presenciais. Assim o feedback seria com relação ao que efetivamente aconteceu na disciplina, ficaria mais fácil para o aluno avaliar e os ajustes deveriam acontecer para os períodos seguintes.

- Não consigo avaliar pois o diagrama do modelo atual não representa um fluxo de trabalho, apenas uma representação dos atores envolvidos e os produtos que se espera ao final do processo.

- $\quad$ Dei 4 e não 5 por um detalhe, não vejo necessidade do aluno "testar" o conteúdo antes. Acho q isso é um processo contínuo e que deve ser feito 
ao longo do curso. Ao fim do curso, pegamos a avaliação dos alunos e também do professor e tutores (faltou isso no seu organograma - onde estão os tutores???) e melhoramos o que for necessário

- A ideia de validar com os alunos é boa. Também acho importante prototipar as atividades antecipadamrnte.

- A proposta em sim é boa. Mas outros fatores devem ser considerados tb

- A nota é principalmente devido a utilização do perfil dos alunos no início. Contudo, a validação e os testes são dispendiosos e demorados para estarem no meio de um processo de produção de disciplina.

- Mais organização para o fluxo de trabalho

- As atividades mudam de acordo com os conteúdos e cada conteúdo tem complexidade específica que possa necessitar diferentes formas de serem apresentados. Além disso, o fator didática, o fator ensino/turma e novidade está sendo esquecido nesse novo modelo. Como testar com o aluno se essas interações são produções a serem apresentadas e manipuladas durante 1 semana para gerar notas e rendimentos!? Como saber o perfil do aluno 1 ano antes de apresentar o conteúdo a ele?! Cada turma pode gerar um perfil diferente. O conteúdo é construído para uma nova turma a conhecer esse material 1 ano depois. Faria o teste com a possível turma no semestre anterior ao do conteúdo, sem sequer saber qual rendimento a turma terá neste semestre corrente e já prevendo comportamentos e modelos de aprendizado pra um conteúdo futuro? Acho inviável e equivocado. O conteúdo não é um sistema com padrões específicos e definidos a gerar reações e interações previsíveis. $\mathrm{O}$ conteúdo pra ser assimilado depende de questões extremamente particulares de cada aluno. Dentro do processo de construção de material que o setor tem não vejo maneira de isso ser feito. Não vejo o aluno como parte integrante de validação pra conteúdo e atividades. Até porque isso impacta na didática do professor . O aluno pode ter um papel avaliador pós apresentação de conteúdo, para possibilitar melhorias futuras, não para inviabilizar a publicação de uma proposta.

\section{9 - "A falta de planejamento do Cecierj desmotiva e subutiliza o potencial} dos funcionários". Sobre essa frase, você:

- Planejamento não significa aumento de etapas. Tem que ser algo objetivo é claro

- Não sei se a pergunta se refere à Fundação como um todo ou à Diretoria de Materiais Didáticos. Em minha opinião o primeiro sequer sabe o que significa planejamento, enquanto o segundo só não consegue planejar-se melhor pelas restrições impostas pelo primeiro.

\section{0 - "Assim como avaliam os cursos e os polos, poderiam nos chamar para avaliar o setor em que trabalhamos, as aulas e o Cecierj. Dar nossa opinião} sobre o que pode ser melhorado." Você:

- Cada setor deve avaliar como trabalha melhor, sem imposições de quem não faz parte do dia a dia. Acaba sendo uma discussão teórica de problemas práticos

- Alguns diretores oferecem avaliação de seus papéis. Mas do setor em si, processos, objetivos, etc, não há.

- desde que isso seja levado em consideração

- Quem avaliaria?

- De uma certa forma já fazemos isso, mas infelizmente não somos ouvidos

- Avaliar o material é útil, avaliar um setor do qual eles estão afastados é inútil e possui a tendência de trazer informações errôneas. 


\section{1 - "Eu já tive ideias, sugestões de implementação, mas foram 'barradas'. A} gente não tem espaço para inovar." Você:

- Pessoalmente, não. Mas já vi muitas ideias serem acatadas, talvez ainda falte muito, mas não sinto o ambiente totalmente fechado à sugestões. Claro que isso ocorre em vários níveis, acho normal algumas sugestões serem acatadas e outras não.

- No meu setor temos bastante liberdade e somos ouvidos.

- Na época q estávamos fazendo q manutenção das disciplinas, tive uma ideia simples q poderia nos ajudar, mas foi barrada com um sonoro não antes de pensarem sobre

- Algumas coisas são barradas por limitações técnicas, outras por questões técnicas e tempo de construção, outra por puro gosto pessoal. O espaço de inovação precisa ser perene e não pontual de um projeto ou outro. Com o tempo de processo que existe na fundação muito se barra por conta da demanda, tempo de execução etc. Deveria se incentivar e dar espaço para o laboratório de Inovação de modo a ter possibilidades prontas para serem usadas e adaptadas quando surgir a possibilidade e utilizá-las de modo a sempre estar se produzindo coisas novas.

22 - "A Fundação tem muita burocracia e centralização. Toda pequena coisa tem que ser levada para um diretor, para o presidente. Isso deixa os processos muito longos." Você:

- Esse é um dos grandes problemas, muito papo e pouca ação

- O engajamento dos gestores tem que estar presente mas com perfil pedagógico e não político como é no momento. Os gestores só se preocupam com suas imagens pessoais em relação ao estado e não com a qualidade dos conteúdos produzidos. Creio que a frase "faz com que tem" seja bem o perfil da fundação.
- Muita coisa não é levada ao presidente, muita coisa é maquiada e levada ao presidente para q ele olhe e seja como ele quer. Mas no fim fazemos o que da e não o que ele acha q está sendo feito.

- A fundação tem características de uma empresa familiar, centralizante, em que não se dá autonomia aos funcionários. Os conceitos de inovação são muitas vezes atrasados e equivocados por parte de quem toma as decisões estratégicas.

\section{3 - "Poderíamos ser consultados periodicamente sobre a necessidade de compra ou de atualização dos softwares e dos computadores." Você:}

- É um absurdo trabalharmos com softwares não legalizados

- Acho importantíssimo atualizar os softwares, mas não tenho ilusões de que isso seria feito sempre, como gostaríamos. A velocidade das atualizações é difícil de acompanhar, envolve disponibilidade constante de verbas. Nem preciso comentar a situação atual... Algumas vezes acho que precisamos ser mais práticos e menos críticos (no sentido de usar o motivo da crítica como impedimento para exercer as atividades).

- Somos consultados mas nunca acontece a compra pois as necessidades e direcionamento de recursos da fundação são para outras questões. Já houveram mais de 5 consultas de compras de software e computadores. Só foi posto em prática quando projetos de professores $(\mathrm{CNPq})$ foram postos em prática na fundação e a aquisição de materiais era obrigatória.

- Aco que poderia haver um porcediento ou canal para solicitarmos isso ou qualquer outro material de trabalho, mas não necesariamente que nos consultassem periodicamente.

- Quem deve opinar são as pessoas q usam juntamente com a equipe de informática 
Apêndice VI - Organograma proposto e validado no

questionário para o Setor de Material Didático do Cecierj

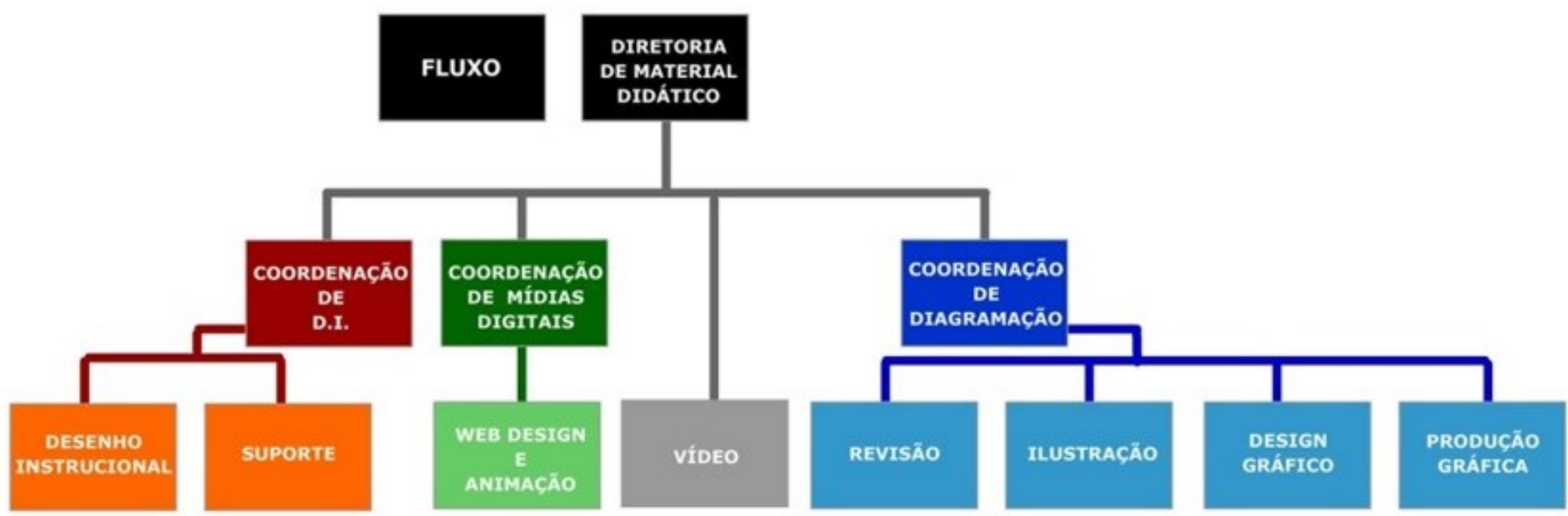


Apêndice VII - Modelo integrado de produção do material didático proposto e validado no questionário

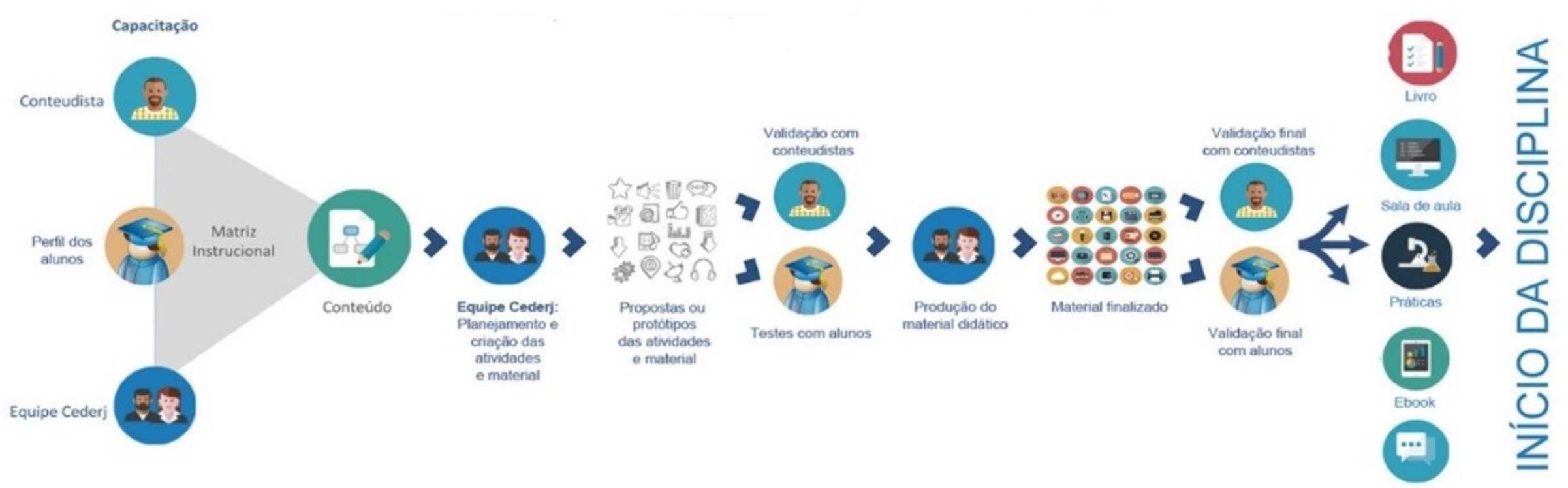

